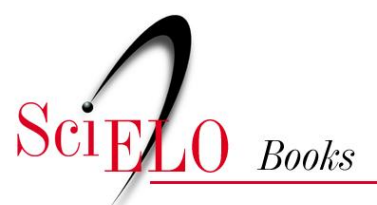

\title{
Saúde do homem em debate
}

\author{
Romeu Gomes (org.)
}

\section{SciELO Books / SciELO Livros / SciELO Libros}

GOMES, R., org. Saúde do homem em debate [online]. Rio de Janeiro: Editora FIOCRUZ, 2011. 228 p. ISBN 978-85-7541-364-7. Available from SciELO Books $<$ http://books.scielo.org $>$.

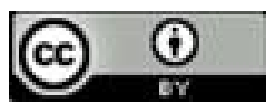

All the contents of this work, except where otherwise noted, is licensed under a Creative Commons Attribution 4.0 International license.

Todo o conteúdo deste trabalho, exceto quando houver ressalva, é publicado sob a licença Creative Commons Atribição 4.0.

Todo el contenido de esta obra, excepto donde se indique lo contrario, está bajo licencia de la licencia Creative Commons Reconocimento 4.0. 


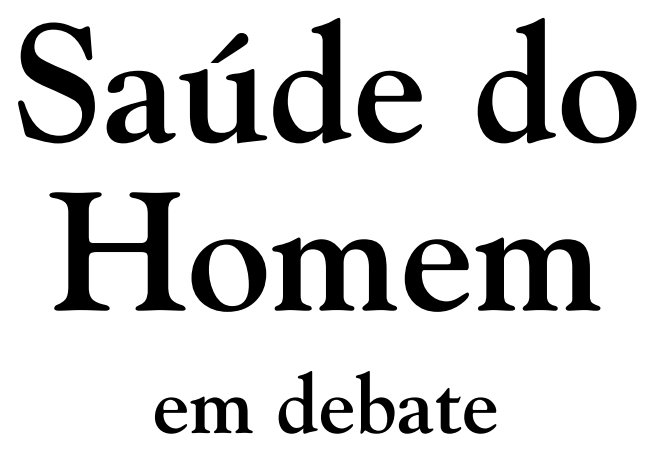




\title{
FUNDAÇÃO OSWALDO CRUZ
}

Presidente

Paulo Gadelha

Vice-Presidente de Ensino, Informação e Comunicação

Nísia Trindade Lima

\section{EDITORA FIOCRUZ}

\author{
Diretora \\ Nísia Trindade Lima
}

Editor Executivo

João Carlos Canossa Mendes

Editores Científicos

Gilberto Hochman e Ricardo Ventura Santos

Conselho Editorial

Ana Lúcia Teles Rabello

Armando de Oliveira Schubach

Carlos E. A. Coimbra Jr.

Gerson Oliveira Penna

Joseli Lannes Vieira

Ligia Vieira da Silva

Maria Cecília de Souza Minayo 


\section{Saúde do Homem em debate}

Romeu Gomes

Organizador

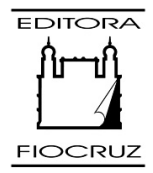


Copyright (C) 2011 dos autores

Todos os direitos desta edição reservados à

FUNDAÇãO OSWALDO CRUZ / EDITORA

Projeto gráfico

Daniel Pose

Revisão

Fernanda Veneu

Supervisão editorial

M. Cecilia G. B. Moreira

Normalização das referências

Clarissa Bravo

Imagem da capa

Mestiço, de Candido Portinari (1934, pintura a óleo/tela, 81 x 65,5 cm, imagem do acervo do Projeto Portinari, reprodução autorizada por João Candido Portinari). Nossos agradecimentos a João Candido Portinari pela cessão de direitos de uso da imagem da obra nesta publicação.

Catalogação na fonte

Instituto de Comunicação e Informação Científica e Tecnológica em Saúde

Biblioteca de Saúde Pública

G633 Gomes, Romeu (Org.)

Saúde do Homem em Debate. / organizado por Romeu Gomes. - Rio de Janeiro: Editora Fiocruz, 2011.

228 p., graf., tab.

ISBN: 978-85-7541-213-8

1. Saúde do Homem. 2. Políticas Públicas de Saúde. 3. Vulnerabilidade. 4. Violência. 5. Sexualidade. 6. Iniquidade Social. 7. Masculinidade. 8. Preconceito. 9. Promoção da Saúde. I. Título.

CDD - 22.ed. - 613.04234

2011

EDITORA FIOCRUZ

Av. Brasil, $4036-1^{\circ}$ andar

sala 112 - Manguinhos

21040-361 - Rio de Janeiro - RJ

Tel.: (21) 3882-9039 e 3882-9007

Telefax: (21) 3882-9006

editora@fiocruz.br

www.fiocruz.br/editora 


\section{Autores}

\section{Benedito Medrado}

Graduado em psicologia, doutor em psicologia social pela Pontifícia Universidade Católica de São Paulo (PUC/SP); professor adjunto da Universidade Federal de Pernambuco (UFPE).

beneditomedrado@gmail.com

\section{Fátima Cecchetto}

Cientista social, doutora em saúde coletiva pelo Instituto de Medicina Social da Universidade do Estado do Rio de Janeiro (IMS/Uerj); pesquisadora do Laboratório de Educação em Ambiente e Saúde do Instituto Oswaldo Cruz da Fundação Oswaldo Cruz (IOC/Fiocruz).

face@ioc.fiocruz.br

\section{Gary Barker}

Jornalista, doutor em psicologia pela Loyola University; diretor internacional do Instituto Promundo (Washington, D. C.) e co-chair da MenEngage Alliance (Washington D. C.).

g.barker@promundo.org.br

\section{Gustavo Saggese}

Cientista social, mestre em saúde coletiva pelo Instituto de Medicina Social da Universidade do Estado do Rio de Janeiro (IMS/Uerj) e doutorando em antropologia social do Programa de Pós-Graduação em Antropologia Social da Universidade de São Paulo (PPGAS/USP).

gsrsaggese@gmail.com

\section{Jorge Lyra}

Psicólogo, doutor em saúde pública pelo Centro de Pesquisas Aggeu Magalhães da Fundação Oswaldo Cruz (CpqAM/Fiocruz); professor adjunto da Universidade Federal de Pernambuco (UFPE).

jorgelyra@gmail.com 


\section{Lilia Blima Schraiber}

Médica, doutora em ciências (medicina preventiva) pela Faculdade de Medicina da Universidade de São Paulo (FMUSP); professora do Departamento de Medicina Preventiva da FMUSP e pesquisadora do CNPq. liliabli@usp.br

\section{Márcia Thereza Couto}

Cientista social, doutora em sociologia pela Universidade Federal de Pernambuco (UFPE); professora do Departamento de Medicina Preventiva da Faculdade de Medicina da Universidade São Paulo (FM/USP). marthet@usp.br

\section{Márcio Segundo}

Cientista político, mestre em ciência política pela Universidade de Brasília $(\mathrm{UnB})_{i}$ coordenador da área de Pesquisa e Avaliação do Instituto Promundo. m.segundo@promundo.org.br

\section{Marcos Nascimento}

Psicólogo, doutorando em saúde coletiva no Instituto de Medicina Social da Universidade do Estado do Rio de Janeiro (IMS/Uerj); consultor independente na área de Gênero, Masculinidades e Prevenção de Violência. m2nascimento@gmail.com

\section{Mariana Azevedo}

Cientista social, mestranda em sociologia na Universidade Federal de Pernambuco (UFPE), integrante da coordenação do Instituto Papai. mariana@papai.org.br

\section{Parry Scott}

Graduado em línguas contemporâneas, doutor em antropologia pela University of Texas (Austin, EUA); professor titular da Universidade Federal de Pernambuco (UFPE) e coordenador do Núcleo de Família, Gênero e Sexualidade (Fages). scott@hotlink.com.br

\section{Pedro Nascimento}

Cientista social, doutor em antropologia social pela Universidade Federal do Rio Grande do Sul (UFRGS), professor adjunto do Instituto de Ciências Sociais da Universidade Federal de Alagoas (Ufal). pedrofgn@uol.com.br 


\section{Romeu Gomes (Organizador)}

Licenciado em sociologia e psicologia, livre-docente em psicologia pela

Universidade do Estado do Rio de Janiero (Uerj) e doutor em saúde pública pela Escola Nacional de Saúde Pública Sergio Arouca da Fundação Oswaldo Cruz (Ensp/Fiocruz); professor titular de antropologia e saúde e pesquisa qualitativa em saúde do Instituto Fernandes Figueira (IFF) da Fiocruz e pesquisador I do CNPq. romeu@iff.fiocruz.br

\section{Sérgio Carrara}

Antropólogo, doutor em antropologia social pelo Museu Nacional da Universidade Federal do Rio de Janeiro (UFRJ); professor do Instituto de Medicina Social da Universidade do Estado Rio de Janeiro (IMS/Uerj), coordenador do Centro Latino-Americano em Sexualidade e Direitos Humanos e pesquisador do $\mathrm{CNPq}$. carrara@ims.uerj.brou sergio_carrara@uol.com.br

\section{Simone Monteiro}

Psicóloga, doutora em saúde pública pela Escola Nacional de Saúde Pública Sergio Arouca da Fundação Oswaldo Cruz (Ensp/Fiocruz); pesquisadora do Laboratório de Educação em Ambiente e Saúde do Instituto Oswaldo Cruz (IOC) da Fiocruz e pesquisadora de produtividade do CNPq. msimone@ioc.fiocruz.br

\section{Wagner dos Santos Figueiredo}

Médico sanitarista, doutor em medicina preventiva pela Faculdade de Medicina da Universidade de São Paulo (FM/USP); professor adjunto do Departamento de Medicina da Universidade Federal de São Carlos (UFSCar).

wagfig1@gmail.com 



\section{Sumário}

1. Integralidade em Saúde e os Homens na Perspectiva Relacional de Gênero Lilia Blima Schraiber e Wagner dos Santos Figueiredo

2. 'Eu Não Sou Só Próstata, Eu Sou um Homem!' Por uma política pública de saúde transformadora da ordem de gênero Benedito Medrado, Jorge Lyra e Mariana Azevedo

3. Vulnerabilidade Masculina, Curso de Vida e Moradia Urbana: um dilema para homens adultos de bairros populares Parry Scott

4. Reflexões sobre a Saúde dos Homens Jovens: uma articulação entre juventude, masculinidade e exclusão social Marcos Nascimento, Márcio Segundo e Gary Baker

5. Discriminação, Cor/Raça e Masculinidade no Âmbito da Saúde: contribuições da pesquisa social Simone Monteiro e Fátima Cecchetto

6. A Sexualidade Masculina em Foco Romeu Gomes

7. De Quem É o Problema? Os homens e a medicalização da reprodução Pedro Nascimento

8. Representações da Violência de Gênero para Homens e Perspectivas para a Prevenção e Promoção da Saúde Márcia Thereza Couto e Lilia Blima Schraiber

9. Masculinidades, Violência e Homofobia Sérgio Carrara e Gustavo Saggese 



\section{Apresentação}

\section{Saúde dos Homens: uma temática em expansão}

Os primeiros estudos sobre a saúde de homens surgiram em fins dos anos 70 do século passado nos Estados Unidos. Esses estudos, quase que exclusivamente centrados em déficits de saúde, tiveram dificuldades para conseguir uma ampla divulgação. Talvez isso tenha ocorrido porque os dados evidenciaram uma certa dualidade, que poderia ser interpretada de maneira equivocada: se, como grupo, os homens estavam em desvantagem em relação às mulheres em termos de taxas de morbimortalidade, em contrapartida, constatava-se que eles detinham mais poder do que elas em todos níveis de classes socioeconômicas (Courtenay \& Keeling, 2000).

Para se lidar com essa e outras questões, foi preciso, ao longo do final do século passado e início do atual, ampliar a discussão para além das instâncias puramente biológicas ou epidemiológicas. A partir dos anos 90, a discussão desta temática passou a refletir, entre outros aspectos, a singularidade do ser saudável e do ser doente entre segmentos masculinos, sem perder a perspectiva relacional de gênero, buscando uma saúde mais integral do homem (Courtenay, 2000; Schraiber, Gomes \& Couto, 2005).

Um exemplo de que a temática tanto teve seu foco ampliado como ultrapassou fronteiras disciplinares é a ampla revisão sobre a saúde de homens, realizada por McKinlay (2005) na Nova Zelândia. O autor analisou fontes diversas que tratavam de: status biológico da saúde de homens; comparações entre a saúde de homens e mulheres; disparidades em saúde; perspectivas filosóficas e sociológicas acerca da masculinidade e dos papéis sociais masculinos; impacto das ações dos profissionais sobre a saúde dos homens e intervenções para a melhoria da saúde de homens. 
Com base nesse estudo, McKinlay concluiu que as diferenças entre os gêneros, em termos de morbidade, mortalidade e expectativa de vida, se explicam, principalmente, a partir de cinco fatores: especificidades biológicogenéticas de homens e mulheres; diferenças sociais e étnicas e desigualdades sociais; associação entre condutas e distintas expectativas sociais de homens e mulheres; busca e uso de serviços de saúde por parte dos homens; cuidados de profissionais de saúde voltados para homens.

McKinlay observou, ainda, que, embora haja certo consenso sobre o fato de o status da saúde do homem estar associado tanto aos aspectos biológicos quanto aos de ordem social, desconhece-se qual desses fatores impacta mais a saúde dos homens e como cada um deles pode a ela se direcionar.

Em 2000 e 2001, a Organização Mundial da Saúde (OMS) lançou duas publicações voltadas para as especificidades da saúde masculina, destacando os comprometimentos dessa saúde em diferentes fases da vida, a partir de uma perspectiva relacional de gênero. A primeira publicação focaliza os rapazes nas ações da área da saúde (WHO, 2000). A segunda propõe princípios para desenvolver políticas e estratégias voltadas para os homens em processo de envelhecimento (WHO, 2001).

A saúde dos homens continuou em cena no âmbito internacional (Baker, 2001). Foi objeto da criação de uma sociedade internacional (International Society for Men's Health and Gender) e de um periódico específico, Journal of Men's Health and Gender (2004).

No Brasil, em 2005, o periódico Ciência \& Saúde Coletiva publicou um número voltado especificamente para a saúde masculina. No editorial, propunha-se a consolidação do homem como foco da saúde pública, no sentido de enfatizar:

a singularidade de um dos pares do gênero e evidenciar novas demandas de 'ressignificação' do masculino, decorrentes de deslocamentos ocorridos no campo do gênero, para que se possa buscar uma saúde para ele voltada. (Gomes, Schraiber \& Couto, 2005: 4)

Os editores assinalavam a necessidade de a saúde pública aprofundar as relações entre ideologias hegemônicas de masculinidade e processo saúdedoença, para que esse campo pudesse enfrentar certas formas do adoecimento e para promover a saúde masculina e feminina.

Ainda em termos de realidade brasileira, em 2008, destaca-se o lançamento para consulta pública da Política Nacional de Atenção Integral à 
Saúde do Homem pelo Ministério da Saúde. Partindo da premissa de que os agravos do sexo masculino são problemas de saúde pública, dentre outros, essa proposta tinha como objetivo:

promover ações de saúde que contribuam significativamente para a compreensão da realidade singular masculina nos seus diversos contextos socioculturais e político-econômicos e que, respeitando os diferentes níveis de desenvolvimento e organização dos sistemas locais de saúde e tipos de gestão, possibilitem o aumento da expectativa de vida e a redução dos índices de morbimortalidade por causas preveníveis e evitáveis nessa população. (Brasil, 2008: 3)

Essa proposta e as outras, anteriormente mencionadas, de certa forma, atestam que a temática saúde de homens encontra-se em expansão. Nesse movimento de expansão, observam-se tanto abordagens que problematizam o assunto quanto aquelas que o limitam.

Para que o debate avance não apenas na quantidade de contribuições, mas também na ampliação do foco da discussão, cabe registrar o posicionamento de White, Fawkner e Holmes (2006). Segundo esses autores, a saúde de homens pode ser definida como tema, condição ou determinante relacionados à qualidade de vida de homens. Pode, ainda, ser vista como requisito para que homens, rapazes e meninos vivenciem saúde física, emocional ou social. Para eles, a saúde de homens ultrapassa a instância específica das doenças relacionadas aos órgãos reprodutivo-sexuais masculinos.

Ainda em relação à construção de uma abordagem ampliada, faz-se necessário reforçar a importância de situar os homens como atores de um determinado gênero, e não apenas como ser humano genérico (Kimmel, 1992). Ganhando essa amplitude, a discussão poderá contribuir não só para se abordar o homem como variável de sexo ou como agente a ser incluído na promoção da saúde da mulher, mas também para considerar os homens como protagonistas da própria saúde.

Essa abordagem poderá trazer pelo menos três subversões para o campo da saúde coletiva:

(1) obriga cientistas e formuladores de política a enfrentar questões das interrelações entre os gêneros, com imensa repercussão nas práticas de prevenção e principalmente na promoção à saúde, deslocando as aproximações individualizantes $_{i}(2)$ traz novas temáticas para os estudos e políticas em saúde da mulher, bem como impõe novos olhares (de gênero) para antigos 
objetos da saúde das mulheres e dos homens, (3) ressalta o entrelaçamento entre saúde, cidadania e direitos humanos. (Schraiber, Gomes \& Couto, 2005: 8)

\section{Abordagens sobre a Saúde de Homens}

O debate sobre a saúde de homens pode envolver diferentes abordagens, atravessadas por distintos campos disciplinares. Conscientes de que existe um amplo espectro de perspectivas que pode ser utilizado para lidar com a temática em questão, faz-se necessário demarcar não somente o campo em que se circunscreve a discussão, como também o seu foco principal.

Procura-se situar o debate no âmbito das questões culturais que potencializam ou limitam os cuidados em saúde a serem assumidos por homens. Para isso, utiliza-se a perspectiva relacional de gênero, ancorada principalmente em uma base socioantropológica, procurando trazer contribuições para as ações de prevenção e promoção da saúde de homens, que integram o campo saúde coletiva.

O capítulo 1, "Integralidade em Saúde e os Homens na Perspectiva Relacional de Gênero", anuncia de pronto a abordagem do debate. Partese, assim, do conceito de 'integralidade em saúde' para se pensar a saúde de homens no cenário relacional de gênero, com uma abordagem interdisciplinar. A discussão é ancorada na premissa de que, ao se planejarem as ações de prevenção e promoção da saúde, é preciso considerar as especificidades nas formas como os homens lidam com o processo saúde e doença. Estas diferenças estão relacionadas à maneira como os indivíduos do sexo masculino veem o cuidado consigo e com o outro.

A integralidade, relacionada à boa prática profissional, às formas de organização das práticas de saúde e às políticas de saúde, é destacada como princípio para: acolher as necessidades de usuários; ampliar o foco no adoecimento a partir de questões relacionadas à vida cultural e social, estabelecer conexões entre ações de saúde pública e as de cunho médicoassistencial ${ }_{i}$ articular demandas espontâneas com as programadas pelas políticas de saúde e integrar diferentes especialidades profissionais. $\mathrm{Na}$ lógica da integralidade, criticam-se as reduções das necessidades de saúde de homens e mulheres ao corpo anatomopatológico.

Também o capítulo 2, "'Eu Não Sou Só Próstata, Eu Sou um Homem!"', adverte sobre a necessidade de não se fazerem reduções sobre o homem. 
O objetivo é revisar estudos e intervenções sociais, no campo dos direitos sexuais e reprodutivos, voltados para homens, destacando principalmente as abordagens e as estratégias utilizadas. Para isso, inicialmente, apresentase uma breve contextualização da trajetória política e conceitual dos debates que situam a masculinidade como construção de gênero e a perspectiva feminista como aporte teórico fundamental. Em seguida, fazse uma análise da visibilidade de dados epidemiológicos sobre adoecimento e morte da população masculina como estratégia discursiva que justifica políticas, define prioridades e produz sujeitos. Por último, desenvolve-se uma leitura crítica acerca dos investimentos recentes em torno da construção de um documento-marco para a política de saúde do homem, na interface com as políticas nacionais voltadas à mulher e aquelas dirigidas ao enfrentamento da homofobia.

No capítulo 3, "Vulnerabilidade Masculina, Curso de Vida e Moradia Urbana", inicia-se a análise a partir das seguintes questões: como as pessoas experimentam o espaço urbano em relação à vivência do curso de vida em espaços domésticos? Quais as suas implicações para a saúde do homem? A discussão continua, aprofundando o assunto tomando como base as perspectivas de gênero, renda e ocupação do espaço urbano. Na primeira parte do capítulo, examinam-se dados censitários para se buscar uma interpretação plausível para compreender as proporções de homens e mulheres que residem em bairros pobres e bairros nobres. Em seguida, procura-se analisar a circulação de homens e mulheres interresidências, interbairros e intergerações, voltando-se para a construção dos significados das vivências espaciais. Na terceira parte, busca-se entender a relação que se estabelece entre homens e serviços de saúde.

O capítulo 4, "Reflexões sobre a Saúde dos Homens Jovens", reflete sobre a articulação entre gênero, geração e condição social na promoção da saúde da população masculina jovem.

Duas partes compõem esse capítulo. Na primeira, aborda-se o contexto das vulnerabilidades às quais os homens jovens estão submetidos. Dentro dessa perspectiva, com base em estudos nacionais e internacionais, são trabalhadas as relações entre homens jovens e a saúde sexual e reprodutiva; o HIV e a Aids; acidentes e violências; mercado de trabalho; educação e serviços de saúde.

A segunda parte do capítulo consiste na problematização de dados de uma pesquisa com homens jovens, com as seguintes temáticas: normas sociais em torno da masculinidade e das relações de gênero; sexualidade e 
uso de preservativo; saúde em geral; cuidado; sexo do profissional de saúde; posto de saúde e doenças sexualmente transmissíveis.

O capítulo 5, "Discriminação, Cor/Raça e Masculinidade no Âmbito da Saúde", desenvolve uma reflexão sobre situações de discriminação associadas à cor/raça no cenário nacional, com implicações no campo dos agravos à saúde. São priorizados dois eixos discursivos: aspectos da discriminação racial no contexto brasileiro remetidos para as especificidades de homens jovens, classificados como negros/pretos, e conexões entre as manifestações de discriminação racial, situações de violência e estilos de masculinidade e seus reflexos nos dados de morbimortalidade masculina. A discussão procura lançar luzes sobre as pesquisas e as políticas de saúde pública voltadas para a população masculina no país.

O capítulo 6, "A Sexualidade Masculina em Foco", começa problematizando as reduções da sexualidade masculina realizadas tanto pela mídia como por fóruns acadêmicos. Em seguida, apresenta o marco conceitual sobre a sexualidade adotado na discussão. O capítulo segue examinando questões relacionadas especificamente à sexualidade masculina, que são examinadas à luz de narrativas sexuais masculinas, partindo-se de uma pesquisa realizada com homens, na cidade do Rio de Janeiro. Princípios para que haja continuidade do debate são apontados como encerramento do trabalho.

No capítulo 7, "De Quem É o Problema? Os homens e a medicalização da reprodução", problematizam-se questões relacionadas aos caminhos, às negociações e às pressões que homens e casais, com 'problemas', vivenciam para ter um filho. A discussão situa-se no cenário da dimensão de gênero e das questões relacionadas aos serviços de saúde. Nesse cenário, são examinadas as chamadas novas tecnologias reprodutivas. A reflexão baseiase em uma pesquisa etnográfica desenvolvida em um hospital público que presta serviços de reprodução assistida. O olhar sobre os dados dessa pesquisa se inicia sobre os aspectos relacionados à fila de espera. Em seguida, se volta para a pergunta 'de quem é o problema?', que sintetiza os questionamentos sobre a causa da dificuldade para se ter filhos.

A discussão continua com as questões relacionadas à medicalização dos corpos, tanto femininos como masculinos. Os comentários finais voltam-se para questões sobre as novas tecnologias reprodutivas, infertilidade e o lugar dos homens na reprodução e na paternidade.

O capítulo 8, "Representações da Violência de Gênero para Homens e Perspectivas para a Prevenção e Promoção da Saúde", inicia com considerações sobre a violência de gênero e as masculinidades, temática 
considerada por alguns de caráter universal. Prosseguindo a discussão, apresenta-se um estudo brasileiro que parte de uma pesquisa multicêntrica. Esse recorte investigativo conjugou o método quantitativo com o de ordem qualitativa, no município de São Paulo e em municípios da Zona da Mata de Pernambuco. Os dados desse estudo são retomados para se fundamentar a análise das seguintes temáticas: o homem e a mulher ideais; relações entre homens e mulheres, e significados associados às relações afetivo-sexuais e à violência contra a mulher. Por fim, são estabelecidas considerações sobre violência de gênero, masculinidades e diversidade cultural remetidas ao campo da saúde.

Por último, no capítulo 9, "Masculinidade(s), Violência e Homofobia", propõe-se uma discussão de violência intragênero, mais especificamente entre homens por conta do rompimento com as convenções sociais de gênero e sexualidade. Examina-se também a discriminação sofrida por aqueles que vivenciam práticas e desejos que não são estruturados a partir da heteronormatividade. Os dados produzidos por um questionário respondido por mais de três mil participantes das paradas de Orgulho LGBT, de quatro capitais brasileiras, é utilizado como base da discussão. Ao longo da análise, os resultados dialogam com outros estudos teóricos e empíricos que estabelecem relações entre homofobia, masculinidade, violência e discriminação.

As abordagens utilizadas pelos autores desta coletânea não necessariamente convergem. Algumas delas se contrapõem dialeticamente, tanto para explicitar contradições quanto para problematizar o tema em foco. Os capítulos, na realidade, são abordagens topológicas, que refletem diferentes dimensões sobre uma grande temática: a saúde de homens. Embora todos autores tratem, direta ou indiretamente, da saúde do homem, cada um o faz sob um ponto de vista diferente.

As contribuições de cada capítulo confluem para uma perspectiva abrangente, estruturada a partir de distintas lógicas utilizadas para se pensar a saúde dos homens. Busca-se, assim, um posicionamento próximo ao de de Will Courtenay (2002), que, além de defender que as abordagens específicas de gênero podem reconhecer diferentes experiências de gênero e várias populações de mulheres e de homens, advoga uma discussão que explore como os fatores biológicos, socioculturais, psicológicos interagem na saúde física e mental de homens.

O Organizador 


\section{Referências}

BAKER, P. The international men's health movement: has grown to the stage that it can start to influence international bodies. British Medical Journal, 323(7.320): $1.014-1.015,2001$.

BRASIL. Ministério de Saúde. Política Nacional de Atenção Integral à Saúde do Homem. 2008. Disponível em: <http://dtr2001.saude.gov.br/sas/PORTARIAS/ Port2008/PT-09-CONS.pdf>. Acesso em: 21 jul. 2009.

COURTENAY, W. H. Constructions of masculinity and their influence on men's wellbeing: a theory of gender and health. Social Science \& Medicine, 50: 1.385$1.401,2000$.

COURTENAY, W. H. A global perspective on the field of men's health: an editorial. International Journal of Men's Health, 1(1): 1-13, 2002.

COURTENAY, W. H. \& KEELING R. Men, gender, and health: toward an interdisciplinary approach. Journal of American College Health, 48: 243-246, 2000 .

GOMES, R.; SCHRAIBER, L. B. \& COUTO, M. T. O homem como foco da saúde pública. Ciência \& Saúde Coletiva, 10(1): 4, 2005.

JOURNAL OF MEN'S HEALTH AND GENDER. Introduction to the International Society for Men's and Gender (ISMH). Journal of Men's Health and Gender, 1: 8-11, 2004. (Editorial).

KIMMEL, M. La producción teórica sobre la masculinidad: nuevos aportes. Isis Internacional - Ediciones de las Mujeres, 17: 129-138, dic. 1992. Disponível em: <www.isis.cl/publicaciones/listaediciones.htm>. Acesso em: 24 fev. 2011.

MCKINLAY, E. Men and Health: a literature review. Wellington: Wellington School of Medicine and Health Sciences, Otago University, jan. 2005. Disponível em: $<$ www.phac.health.govt.nz/moh.nsf/pagescm/766/\$File/mens-health-literaturereview.pdf>. Acesso em: 21 jul. 2009.

SCHRAIBER, L. B.; GOMES, R. \& COUTO, M. T. Homens na pauta da saúde coletiva. Ciências \& Saúde Coletiva, 10(1): 7-17. 2005.

WHITE, A.; FAWKNER, H. J. \& HOLMES M. Is there a case for differential treatment of young men and women? The Medical Journal of Australia, 185(8): 454-455, 2006.

WORLD HEALTH ORGANIZATION (WHO). Boys in the Picture. Genève: WHO, 2000.

WORLD HEALTH ORGANIZATION (WHO). Men, Ageing and Health. Genève: WHO, 2001. 


\section{Integralidade em Saúde e os Homens na Perspectiva Relacional de Gênero} Lilia Blima Schraiber e Wagner dos Santos Figueiredo

Pretende-se trabalhar o conceito de 'integralidade em saúde', em termos de sua origem e desenvolvimento atual, mostrando-se de que modo contribui para pensar a interdisciplinaridade em saúde, quer para a abordagem de novos objetos de conhecimento, quer para propor intervenções nos serviços.

O novo objeto em tela dirá respeito à tomada das necessidades de saúde e demandas de atenção que os homens frequentemente portam, mas problematizadas da perspectiva de gênero. Esta perspectiva significará considerar os exercícios das masculinidades, expressões concretas e diversas relativamente ao modelo identitário hegemônico. Isto significa ora reiterar, ora negar aspectos desse referencial hegemônico e que, na saúde, são conexos ao reconhecimento, por parte dos indivíduos do sexo masculino, de suas necessidades e à forma de apresentação destas em demandas para os serviços.

Com isso já se afirma, mesmo que preliminarmente, que há um modo particular como os homens reconhecem e apresentam questões ligadas ao processo saúde-doença nos serviços, até mesmo quando deixam de qualificar certas situações vividas como atinentes à sua saúde ou seu adoecimento, e, neste caso, evitando a busca pelos serviços de saúde. Especial atenção merecerão as problemáticas da prevenção e promoção da saúde, com suas questões bastante ligadas ao cuidado, de si ou de outros.

O destaque à atenção primária é significativo, uma vez que os homens valorizam menos e estão menos presentes, como usuários, nas unidades básicas de saúde, que são os serviços que representam essa atenção. Da mesma forma isto ocorre com o cuidado. Mais do que os 
tratamentos das doenças, a valorização do cuidado tem sido reiteradamente apontada como questão a se criticar no modo como os homens lidam com sua saúde (Schraiber, Gomes \& Couto, 2005; Figueiredo, 2008).

Faz-se um recorte de aproximação dessa problemática, refletindose de que modo a integralidade pode se inscrever em algumas questões que cercam homens adultos e em situação de conjugalidade ou parcerias afetivo-sexuais, tais como sua saúde reprodutiva e sexual. Estas temáticas permitem estabelecer um diálogo com a saúde reprodutiva e sexual das mulheres, tomando por base o Programa de Atenção Integral à Saúde da Mulher (Paism). A importância desse diálogo é dupla. Primeiro, pelos aspectos de gênero, tomado como conceito tradutor de uma realidade imediatamente relacional entre homens e mulheres. Além disso, por ter sido o Paism o primeiro programa a formular e implementar a integralidade em saúde no plano das práticas profissionais, concebidas estas como o agir técnico e assistencial, isto é, o plano imediato do atendimento aos casos. É neste plano que também buscou incidir o Paism como proposta crítica e de renovação da redução biomédica das necessidades de saúde das mulheres, o que se retoma mais adiante.

O trecho a seguir, transcrito de relatório de pesquisa de estudo sobre as desigualdades de gênero no Programa de Saúde da Família em Recife (Tavares et al., 2004), é um bom exemplo dos aspectos de gênero com que se quer trabalhar aqui.

Dizem que, em geral, quando chegam no posto, "eles ficam um pouco sem jeito", que estão "trazendo [os homens] aos poucos" mas que é um "trabalho lento" porque "homem é cabecinha dura". Relatam outros casos, sempre nomeadamente e a partir da mulher: o marido de fulana, por exemplo. A ACS resume: "não é todo homem que vem no posto, mas a gente vai trazendo na medida do possível. (...) Outra lembra a vergonha, homem tem vergonha de vir ao médico ou dentista. O trabalho é outro argumento bastante usado por profissionais e usuários como razão para a menor frequência de homens às unidades. Me ocorre que ir ao serviço é coisa para mulheres, velhos e desocupados, e os homens não querem este lugar de jeito nenhum. Homens usam o serviço mais para curativo, dentista e outras coisas consideradas "importantes". A maioria dos profissionais acha que eles não gostam de falar de suas vidas, não colaboram nos cuidados relativos à prevenção de DST e planejamento familiar, não se cuidam e não previnem as doenças. (Tavares et al., 2004: 49) 
Os primeiros resultados da pesquisa mencionada encontram-se em Silva (2005) e Schraiber (2005).

\section{Saúde e Integralidade}

Situando melhor esta noção de integralidade, pode-se considerála como referência, ao mesmo tempo produto e produtora de um projeto particular no campo da saúde, o da saúde coletiva. Será importante conceituar 'projeto', pois dará base de compreensão da perspectiva não apenas técnica ou profissional da integralidade, mas também política, em que a integralidade passa a ser uma proposição de reforma da saúde e da sociedade. Esta última, como se vai ver, implicará outra perspectiva cultural relativamente àquela que é hegemônica no campo. Em outros termos, trata-se de abordagem que dirá respeito a uma perspectiva diversa da medicalização de base biomédica dos determinantes sociais do adoecimento ou dos problemas de saúde em geral, para a definição e tomada das necessidades de saúde da população, o que se examinará para a saúde dos homens em particular.

A definição sartriana de projeto (Sartre, 1987) permite a passagem da ação para o agir. Dá destaque, assim, à intenção e ao desempenho do sujeito quando este realiza uma ação. Isto quer dizer que o sujeito é capaz de modificar o curso da ação, como consequência de decisões e escolhas que venha a realizar ao longo dessa mesma ação.

Todo agente de uma ação, ao colocar-se como sujeito, pode, pois, inová-la ao tempo em que a realiza, mesmo que se trate de proceder bastante predefinido, como o é uma técnica científica, e mesmo que seja delimitado quanto às possibilidades de sua execução pelos recursos existentes nos contextos de sua produção, tal como se verifica em muitos dos serviços de saúde.

Sem negar os constrangimentos que o modo dominante das relações sociais de produção impõe a toda prática social, na adesão à teoria marxista da produção social, Sarte fala de um agente empreendedor, que cria e abre perspectivas futuras mesmo reproduzindo as exigências do mundo exterior, a objetividade social. Isto porque, ao reproduzir tais exigências, como resultado do processo de aculturação na sociedade em que vive - o que, no caso dos profissionais da saúde, também é dado pelo aprendizado escolar de profissionalização -, o agente imprime mudanças e marcas nesse mundo exterior. São marcas que traduzem a intencionalidade de sua ação 
tanto em decorrência das representações forjadas em experiências pregressas - significados que já detém sobre a realidade e que atualiza a partir de sua interação com ela - quanto pela perspectiva implícita nesses significados: a de realizar um futuro, isto é, de conquistar o ideal perseguido ou o dever-ser esperado, o que corresponderá à sua ideologia ocupacional (Chauí, 1982).

Sartre (1987) fala em movimentos conjuntos de "interiorização do exterior" e de "exteriorização do interior". Essa exteriorização, após a interiorização da realidade objetiva, é o processamento dessa realidade, então negada e superada, e seguida de nova objetivação sob a forma de projeto.

Ao conceber projeto como mediação entre dois momentos de objetividade, Sartre define a prática como uma passagem da objetividade primeira à nova objetividade, através da interiorização. A postulação de dois movimentos recíprocos entre o exterior e o interior do sujeito serve para refletir sobre as interações desse sujeito com a realidade material e desse sujeito individual com o coletivo social e suas normas. Trata-se da dialética que articula o sujeito social às estruturas, articulação que também se adota não só com base nos estudos de Marx sobre as relações de produção no capitalismo, indicando a marca histórica e social de toda prática, mas também com base nos estudos específicos do campo da saúde sobre a medicina ou a saúde pública (Donnangelo, 1976; MendesGonçalves, 1984, 1994; Nogueira, 2007; Schraiber, 1993, 2008; Ayres, 1995). Estes autores demonstram e conceituam, em releituras de autores tão diversos como Clavreul (1983), Polack (1971), Foucault (1977,1984), Illich (1975), Conti (1972), Rosen (1983), Sigerist (1974) e Canguilhem (1982), a socialidade e a historicidade das práticas de saúde, quer como produção de conhecimento, quer como trabalho social.

Tomada esta formulação como um todo, a noção de projeto permite compreender as práticas de saúde como parte das práticas sociais, alinhando-se histórica e socialmente em suas concretizações técnicas e científicas. Mas, principalmente, projeto permite postular esse alinhamento de modo processual, relativizando a determinação estrutural que deixa de ser absoluta e mecânica e passa a ser movimento. Este é dialético, com tensões entre aspectos diversos e contrários, o que se pode enunciar como: as práticas de saúde reproduzem, sem apenas reiterar, mas pondo em dinâmica de negação e, portanto, em movimento, o modo de vida social. Ou, como já dito acerca da prática médica: 
não se toma a presença do social nas práticas como uma determinação mecânica, ou seja, não basta conhecer as questões sociais para que se reconheçam as da medicina, mas parte-se da ideia de que o social na medicina está nas peculiaridades da própria medicina, e não em sua repetição direta, o que permite ver dentro dela a vida social sendo vivida de modo particular. Se assim não fosse, o resultado seria um descaminho para se conhecer a prática em seu lado técnico, uma vez que esse lado "interno" se transformaria em mero reflexo de seu exterior. O uso mecânico das determinações sociais desqualifica o conhecimento das peculiaridades das situações particulares que pertencem ao social, impedindo, por exemplo, de se conhecer a realidade técnica e tecnológica do trabalho médico como prática social. Esse uso mecânico também impede que se conheçam processos de subjetivação, isto é, passa-se a tomar os profissionais, por exemplo, como mero produto das condições de trabalho ou recursos-objetos da própria técnica, tornando o médico um agente não atuante e totalmente determinado pela organização de seu trabalho. (Schraiber, 2008: 36-37)

É evidente, aqui, uma certa aproximação com os conceitos de habitus e de reprodução de Bourdieu (1974, 1996), quando o autor, de significativa presença na produção intelectual do campo da saúde coletiva, trata de um agente de prática ao mesmo tempo reprodutor da estrutura em que se insere e inovador.

Assim, no caso dos profissionais de saúde, projeto significa a busca de realização dos ideais de profissão, momento em que cada profissional como agente de prática de sua área de atuação, relaciona-se com as referências sociais e históricas de produção. Ou, nos dizeres de Ayres (1995: 78):

O projeto é, portanto, a expressão abstrata dessa vontade que é ao mesmo tempo social e individual. Social porque só adquire realidade como processo coletivo (...). O projeto só é projeto porque se situa tensamente entre possibilidades e necessidades diversas, por referência a um mesmo campo de práticas. Por outro lado, essa diversidade está fundada na singularidade dos indivíduos, a qual só se define como tal contra o pano de fundo dos coletivos em que estão mergulhados.

Para o campo da saúde, tomado como o coletivo desses profissionais, o projeto representa a busca de realização dos princípios de sua estruturação 
e vida como campo, buscando realizar ideais propostos para as práticas de saúde em seu conjunto e como conjunto. Essa proposição de ideal é cunhada por intelectuais que o formulam na qualidade de representantes legitimamente reconhecidos pelo movimento social que cria e desenvolve o próprio campo (Paim, 2008). Com isto se quer evidenciar a existência de 'intelectuais orgânicos de projeto' (Gramsci, 1968) do campo da saúde, já advertindo da igual existência de disputas internas ao próprio campo, entre diversas correntes de pensamento profissional e ideologias ocupacionais. Basta lembrar, nesse sentido, os projetos tão distintos envolvidos na saúde, tais como os da medicina e os da saúde pública, bem como os internos a cada um desses subcampos (Campos, 1988; Donnangelo, 1975; Nogueira, 1984; Merhy, 1992; Paim \& Almeida Filho, 2000; Paim, 2007).

A proposta da integralidade será, então, um desses projetos em disputa no campo. Por se configurar de modo bastante peculiar no Brasil, a saúde pôde construir um subcampo, a saúde coletiva, com pretensões de realizar do ponto de vista ético, político, administrativo e tecnológico-assistencial uma articulação de seus segmentos internos, tal que resultasse em trocas interativas e cooperações entre seus diferentes conhecimentos, práticas, agentes e instituições da produção social de assistência médica ou sanitária.

Historicamente desenvolve-se no país uma dinâmica muito particular da relação entre dois grandes domínios de atuação, ou subcampos de competência, relativos aos processos saúde-doença e que cedo, na modernidade, se estruturam e se individualizam: o domínio sobre o adoecimento individualmente considerado e aquele de base populacional ou coletiva. O primeiro corresponde à medicina - seu saber, sua prática, seu modo de produzir a assistência, seus profissionais (ou agentes do saber e da prática), sua reprodução através da produção científica e tecnológica de conhecimentos, sua contínua formação de agentes nas escolas, nos sistemas de divulgação e a permanente disseminação de seu saber, aculturando também continuamente a sociedade na qual se dá como campo de prática social. O outro domínio mencionado, e que toma o adoecimento em sua dimensão coletiva, é a saúde pública, igualmente com os componentes já citados para a medicina, os quais, tal qual nesta, constroem a conformação de campo de práticas de saúde, desta feita, para o coletivo da sociedade.

Assim, embora ambos os domínios tratem dos processos de adoecimentos e recuperações, dizendo respeito nessa esfera mais geral à mesma realidade concreta, o modo como cada qual se aproxima dos 
adoecimentos, explica-os e propõe intervenções é bastante diverso (Mendes-Gonçalves, 1994). Também o serão a perspectiva da prevenção do adoecimento e a da promoção da saúde, as quais, tomadas do ponto de vista individual, orientam-se para disciplinas e comportamentos pessoais (o estilo de vida e o comportamento de risco) e, do ponto de vista coletivo, para mudanças da produção social de bens e produtos em geral, e equanimidades de acesso e consumo destes (Rose, 1988). Assim, haverá sempre grandes diferenças entre aconselhar o indivíduo a não fumar ou beber ou se alimentar de forma mais saudável e implementar políticas e normas legais que disponibilizem a toda a população alimentos livres de agrotóxicos e outras químicas, ou ambientes saudáveis em qualquer espaço etc.

Uma maior articulação e cooperação entre as práticas da medicina e as da saúde pública esteve logo, portanto, entre as primeiras pretensões da saúde coletiva e na qual reconhecemos a temática da 'integração médico-sanitária' (Mendes-Gonçalves, 1994). No entanto, o projeto não se esgota aí.

Nascendo de uma crítica à medicina e à saúde pública hegemônicas nos anos 70 e com pretensões políticas de reforma social, a saúde coletiva abraça a problemática dos direitos humanos e sociais, assim como a elaboração de projetos e políticas de maior equidade social, revelando-se mais do que uma reforma do sistema de atenção à saúde (Paim, 2008). Dispôs-se, desde a origem, a trabalhar explicitamente com duas articulações: a da medicina com a saúde pública, há pouco mencionada, e a dos saberes de cada qual com as respectivas práticas na rede de serviços. Nisto, criticou e tornou explícita a ausência dessas articulações. Trata-se, assim, de um pensamento que argui exatamente a concepção de que dos saberes derivam mecanicamente as práticas assistenciais dos profissionais em medicina e em saúde pública, e a concepção de que a própria saúde pública deriva da medicina.

A saúde coletiva propôs duas mudanças: uma reorientação da saúde pública tradicional, em aproximação da medicina, mas também uma reorientação desta última. Aproxima-se da crítica à fragmentação do ato médico e sua progressiva especialização, configurada nos movimentos americanos de reforma médica e que formularam as propostas de medicina integral, medicina preventiva e medicina comunitária. Estes buscaram uma medicina mais compreensiva, holística, em torno ao 'todo biopsicossocial' (Donnangelo, 1976), de que decorrerá uma certa disposição interdisciplinar 
relativamente, senão às ciências sociais e humanas como um todo, ao menos às chamadas ciências do comportamento e no sentido complementar ao enfoque estritamente biomédico operado pelas ciências que dão base à medicina.

Já com a crítica à própria medicina preventiva ali proposta, pela construção conservadora e liberal de saúde como questão individual e não social (isentando o Estado de qualquer responsabilidade em seu provimento ou regulação), a saúde coletiva comprometerá seu projeto interdisciplinar em outro sentido (Arouca, 2003). Valorizará as ciências sociais e humanas mais voltadas às questões éticas e políticas do social, em resgate à ideia de medicina social (García, 1985) e articulará sua interdisciplinaridade em um projeto diretamente político, na conquista de direitos de cidadania e na democratização da assistência e benefícios da medicina e da saúde pública.

O termo 'coletiva' adicionado à saúde pretendeu anunciar esta crítica à soberania do individualismo, ressaltando os deveres do Estado para com sua população. Com isto, a saúde coletiva não delimitou seu escopo de atuação ao plano do espaço público da sociedade, expandindo sua competência para os domínios tradicionais da medicina, com sua assistência à vida privada e ao individual. Trata-se de uma integração médico-sanitária agora reorientada para o compromisso ético-político da equidade social, já revendo seu termo 'medicina' quanto à integração multidisciplinar e multiprofissional.

Essa origem é datada e corresponde a um movimento social de época. Emergindo nos anos 70, a saúde coletiva constituiu-se no país no período da ditadura militar e das lutas por melhores condições de vida, contra a pobreza e a carestia. Toda uma cooperação ocorrerá entre os pesquisadores das universidades e os militantes dos movimentos sociais para a democratização do próprio Estado.

A saúde coletiva, assim, estabelece-se como subcampo da saúde com projeto de reforma sanitária e de reforma social, no qual incluía a reforma do próprio Estado (Paim, 2008). Propôs novas políticas de saúde, novas modalidades de organizar e distribuir a produção da assistência à população, em novas modalidades institucionais de prestar serviços de saúde e, ainda, novas aproximações das necessidades de saúde.

Esse conjunto é conhecido como 'novo modelo de atenção em saúde' (Paim, 2007). Pode-se especificá-lo melhor: novo modelo 'assistencial' e 'tecnológico', sendo esses dois termos qualificadores de uma separação apenas 
explicitadora das duas dimensões que necessariamente encerra - a produção social da assistência com questões dos direitos de acesso e equidade assistencial ${ }_{i}$ as práticas profissionais (técnico-científicas) e suas organizações na produção dos trabalhos médico e sanitário para a sociedade.

Neste movimento que é técnico, por seus saberes e práticas, e também político, a saúde coletiva abre-se ao social e ao cultural para compor o conceito de integralidade. Nos dizeres de Paim (2007:15), a integralidade, por essa origem e desenvolvimento, diz respeito a

pelo menos quatro perspectivas: a) como integração de ações de promoção, proteção, recuperação e reabilitação da saúde compondo níveis de prevenção primária, secundária e terciária b) como forma de atuação profissional abrangendo as dimensões biológica, psicológica e social, c) como garantia de continuidade da atenção nos distintos níveis de complexidade do sistema de serviços de saúde $;$ d) como articulação de um conjunto de políticas públicas vinculadas a uma totalidade de projetos de mudanças (Reforma Urbana, Reforma Agrária etc.) que incidissem sobre as condições de vida, determinantes da saúde e dos riscos de adoecimento, mediante ação intersetorial.

Nessas considerações do autor, fica claro que a saúde coletiva também, progressivamente, constitui como sua competência produzir conhecimentos e atuar nas políticas de saúde, no planejamento, gestão e avaliação dos serviços, e no provimento de atenção integral à saúde da população em todos os seus segmentos.

Pode-se dizer, assim, que o projeto da integralidade não somente está em cada uma dessas três esferas de atuação (a dimensão das políticas, do planejamento e gestão e das práticas profissionais), mas também as perpassa, buscando articulá-las entre si (Schraiber, 1995). E, em consonância com os próprios postulados gerais do campo, como reiteram Pinheiro e Mattos (2001), a integralidade relaciona-se a um ideal de sociedade mais justa e solidária, aderindo a valores pelos quais vale a pena lutar.

Pinheiro e Mattos (2001) reconhecem igualmente as três esferas em que deve incidir o projeto da integralidade, apontando que ela, em seus vários sentidos, dirá respeito a uma boa prática profissional, ao modo de organizar as práticas de saúde e às políticas de saúde. $\mathrm{O}$ primeiro se refere ao modo ampliado de acolher as necessidades dos usuários, procurando produzir tanto ações de prevenção, como responder às demandas. Por outro lado, alertam que as necessidades não se limitam ao 
adoecimento, mas configuram questões relacionadas a aspectos da vida cultural e social consideradas relevantes para a qualidade da saúde.

Já como organização dos serviços, os autores apontam para uma série de articulações desejáveis: das ações de saúde pública com ações médicoassistenciais; da demanda espontânea com a programada pelas políticas de saúde, requerendo, ainda, o concurso de diferentes especialidades médicas e de diferentes profissionais, em trabalho de equipe. Para que a integralidade se estabeleça, é necessário assumir, como ponto de partida, a perspectiva de um diálogo entre diferentes sujeitos e diferentes instituições e seus diferentes modos de perceber as necessidades de serviços de saúde, buscando intervenções diversas e ampliando os horizontes dos problemas a serem tratados pela política de saúde. Entre os exemplos desse tipo de integralidade, Pinheiro e Mattos (2011) apontam o Programa de Atenção Integral à Saúde da Mulher (Paism), um dos pioneiros deste tipo de política, e o Programa Nacional de Aids, mais recentemente.

Pode-se afirmar, assim, que, desde os anos 80, a integralidade em saúde vem sendo colocada como questão, nas políticas governamentais, em programas de intervenção e no discurso dos intelectuais da saúde coletiva, constituindo, na atualidade, um dos temas sob forte debate (Pinheiro \& Mattos, 2001, 2003). Já foi pensada em termos mais restritos de uma articulação entre aparatos institucionais prestadores de serviços, como a integração entre os setores público e privado na produção da assistência médica, ou entre os subsetores de saúde pública e de medicina previdenciária, no interior do próprio setor público de serviços. Depois, foi pensada também como um problema de gerência interna dos próprios serviços. De qualquer modo, esteve sempre explicitada como intenção e necessidade da ação pública, até erigir-se em um dos princípios do próprio Sistema Único de Saúde brasileiro, o SUS, em que tão presente esteve a saúde coletiva.

A integralidade em saúde desenvolveu-se mais no plano macrossocial das políticas, desenhando outro e melhor 'modelo assistencial'. Em contrapartida, maturou-se menos em proposições reformadoras das práticas profissionais: a 'boa prática em saúde', questão em debate já no século XXI, sob os auspícios, sobretudo, do movimento de humanização e do conceito de 'cuidado em saúde', mesmo que este último seja, ainda, um conceito bastante polissêmico (Ayres, 2004; Deslandes, 2006; Pinheiro \& Mattos, 2005). 
Por isso, dir-se-á que a integralidade oferece, atualmente, a possibilidade de se pensar melhor o agir profissional e os cuidados em saúde, revitalizando as ações técnicas como construções técnico-científicas e construções humanas de intervenções. Na perspectiva de integrar, leva ainda a outra renovação: a da concepção de 'eficácia técnica', em que não só o produto da ação ou o tratamento das doenças está em jogo, mas também a própria relação interativa do profissional com os usuários. Trata-se da valorização da interação como participante da eficácia técnica. Pode-se dizer: cada profissional terá de romper com sua autonomia absoluta, com sua total independência de decisão, para uma autonomia interdependente em que partilha a tomada de decisões e a elaboração do projeto terapêutico com outros, incluindo-se aí o próprio usuário ou paciente.

A integralidade remete, sem dúvida, para o trabalho em equipe. Neste, a integralidade traz duas importantes contribuições que passam a reestruturar a questão do trabalho em equipe de forma nova: a de que as ações técnicas são também trocas intersubjetivas e comunicação, e a de que as ações de cuidado não são apenas dependentes do conhecimento e dos saberes técnico-científico específicos. A integralidade não se resume, pois, a uma interdisciplinaridade e esta não esgota o trabalho em equipe, o qual deve conter a articulação das ações profissionais e a interação (agir comunicativo) interprofissional.

Caberia lembrar que, ao se trazer a dimensão interativa para o interior das ações, este processo termina por colaborar também no sentido da revitalização da própria esfera da política e da gerência dos serviços e seus modelos de gestão. A interação como problema remete imediatamente à discussão ética das ações propostas e, nisto, permite refletir criticamente sobre a política e seu caráter público, bem como sobre as instituições e a legitimidade de suas normatizações. A comunicação, criticada no plano das relações entre profissionais e seus pacientes, ou dos profissionais entre si, surge também como questão de relacionamento entre o Estado e a sociedade ou entre gerentes e profissionais. A problemática da integralidade no plano dos cuidados repercute assim nestes outros âmbitos das ações em saúde.

Pensar a relação que articula a política, a gestão e as práticas profissionais, mas partindo desta última para alcançar as primeiras, é uma aproximação pouco usual nas discussões acerca dos modelos assistenciais e da própria questão da integralidade em saúde, geralmente problematizada, sobretudo, como política e gestão. Quer-se chamar atenção para o movimento e contribuição próprios da construção do 
Paism, posto ter buscado reorientar a assistência e sua política desde a indagação assentada diretamente no objeto de intervenção das práticas profissionais e suas ações técnicas: a quem pertence o corpo das mulheres?

\section{Gênero e Integralidade}

O início da postulação das questões de gênero na saúde pode ser demarcado com a proposição do Paism, nos anos 80. Este programa, ao ser parte da Reforma Sanitária e do campo da saúde coletiva em consolidação, foi construído na articulação dos profissionais da saúde coletiva com o movimento social feminista. Sustentou, pela primeira vez, a necessidade de uma atenção integral ao sujeito mulher que escapasse da sua tradicional redução à função reprodutiva.

Seu movimento primeiro é a crítica à saúde reprodutiva no modo pelo qual se tomava a própria mulher como alvo da medicina e suas práticas. Caracterizou um movimento crítico à abordagem biomédica da mulher apenas em sua condição materna, medicalizando o corpo feminino ao reduzilo à sua capacidade reprodutora, ao mesmo tempo que reduzia e reforçava culturalmente a atribuição de mãe como identidade social feminina.

A formulação da saúde da mulher em termos de um maternoinfantilismo daria conta no plano simbólico e material de toda essa construção, vigente desde o século XIX até a década de 1980. Nela não há questão feminina para a saúde sem crianças, não havendo, então, necessidades de saúde fora da reprodução.

Já bem estudada, esta é uma estratégia biopolítica de atuação e controle das populações, inserindo a mulher como responsável por essa atribuição, a princípio de ter filhos e depois de planejar quando e quantos tê-los, na disciplina da contracepção. Pode-se observar, desde aí, a distinção e separação entre reprodução biológica e sexualidade, situações que concretizam as relações e desigualdades de gênero nas sociedades.

Em oposição e com o lema 'nosso corpo nos pertence' (Correa \& Ávila, 2003), é que se proporá a nova abordagem da mulher e de sua saúde, elaborando-se o Paism. Cronologicamente posterior no campo, ainda que não nos movimentos feministas, inscreve-se a questão da violência de gênero contra a mulher. Emerge em meados dos anos 70, quando o movimento feminista contrapõe à tese jurídica da 'legítima defesa da honra', o lema 'quem ama não mata', opondo-se aos crimes em que os maridos poderiam ser absolvidos judicialmente do assassinato de suas 
esposas (Barsted, 2003). Na saúde, a partir principalmente dos anos 90, a violência pode ser considerada questão, ainda hoje, polêmica como necessidade de saúde e parte dos temas invisíveis nos serviços de saúde (Kiss \& Schraiber, 2011).

Embora inscrita como tema geral, para a violência não são formuladas de início ações específicas de atenção, o que se desenvolverá notadamente a partir da segunda metade da década de 1990. Todavia, a integralidade, expressa no nome do programa, já antecipava a futura inscrição, pois, embora com diversas interpretações e encerrando diversos sentidos (Villela \& Monteiro, 2005; D'Oliveira \& Senna, 2000), a atenção integral das mulheres ali proposta indaga, pioneiramente, a abordagem da mulher não apenas como um corpo anatomofisiológico, mas como um sujeito social dotado de direitos. E o projeto de integralidade, neste caso, trouxe, para as práticas de saúde, entre outras questões que definem um sujeito social, as da desigualdade de gênero, articulando de imediato o agir profissional com a política pública diante de tais desigualdades.

Esta inicial postulação de gênero, como olhar estruturador da aproximação das necessidades de saúde e das propostas assistenciais para satisfazê-las, dá-se a princípio voltada para as mulheres. Os homens, como objeto específico de atenção à saúde, só seriam considerados em perspectiva similar vinte anos mais tarde (Schraiber, Gomes \& Couto, 2005).

Também neste caso da perspectiva de gênero, a crítica das práticas profissionais e do modelo assistencial é dirigida às reduções das necessidades dos sujeitos e das determinações socioculturais de seu adoecimento à dimensão biopatológica, que faz parte dessas necessidades, sem, contudo, esgotá-las. A essa racionalidade, oriunda da medicalização do social, também na perspectiva de gênero (Vieira, 2002), opõe-se criticamente o projeto da integração de saberes e ações e de interação de seus agentes.

Mas em que aspecto ou dimensão das práticas profissionais tal projeto poderia ser executado?

Retome-se aqui a discussão anterior sobre a própria noção de projeto e a inscrição de sua possibilidade enquanto agir profissional mais do que a execução de ação como aplicação rotineira e mecânica dos saberes técnicos e científicos. Com base no conceito de agir profissional, podemos ressignificar as próprias ações concretamente operadas no cotidiano dos serviços, pois, como se viu, estas incluem a perspectiva da subjetividade dos agentes das práticas. As ações desenvolvidas são produto, portanto, 
também das representações, concepções e crenças que os profissionais e mesmo a clientela detêm acerca das questões de saúde e, nelas, das relações de gênero (Schraiber, 2005). Em outros termos, se a organização e os saberes técnico-científicos atuam como dispositivos objetivamente estruturadores das ações, a subjetividade dos agentes do trabalho em saúde também conforma suas práticas, reorientando elementos do saber ou mesmo da organização objetiva da prestação de serviços e desenvolvimento dos trabalhos na unidade de saúde.

É também por essas especificidades do agir profissional que, mesmo sem conceberem, esses agentes reproduzem as representações de gênero tradicionais da sociedade, reproduzindo suas desigualdades de poder e valor, e reiterando na saúde as repartições de atribuições e expectativas para as identidades masculinas e femininas (Schraiber, 2005).

Por isso veremos que, se homens e mulheres são também, perante a saúde, sujeitos desiguais, desde o valor do adoecer às atribuições de cuidado de si e de outros, o atendimento a mulheres e homens na atenção primária reitera as desigualdades. Esse atendimento reproduz, em diversos sentidos, as relações sociais mais gerais, desde a forma com que são tomadas as necessidades de saúde de homens e mulheres na assistência cotidiana, bem como são elaboradas suas propostas terapêuticas.

É reconhecida pela literatura (Schraiber, Gomes \& Couto, 2005), por exemplo, a atribuição de cuidados domésticos exclusivamente às mulheres. Assim, ocupar-se dos afazeres na lida da casa, da educação das crianças, do cuidado dos idosos, além de cuidar dos doentes, seriam responsabilidades das mulheres, isentando-se os homens dessas tarefas por terem a atribuição de provedores, trabalhando fora da casa para $o$ sustendo da família, atribuição tida como mais importante do que a lida doméstica e realizada por muitos anos exclusivamente como tarefa masculina.

Ao mesmo tempo, também é reconhecida a quase interdição dos homens ao cuidado de si, da perspectiva mais preventiva, devendo apenas ausentar-se do trabalho somente em condições de graves adoecimentos (Schraiber, Gomes \& Couto, 2005). Os serviços de saúde, em particular a atenção primária, são vistos culturalmente como o espaço das mulheres, com a assistência para si mesmas, trazendo as crianças e representando seus parceiros ou os outros homens da casa (Villela \& Monteiro, 2005; Figueiredo, 2005). 
Parte da questão da integralidade no caso masculino reside, então, nas mesmas operações redutoras de suas necessidades de saúde ao corpo anatomopatológico, como ocorre com as mulheres, ainda que, neste caso, este corpo deverá servir, tal qual historicamente se constituiu, como força de trabalho nas indústrias e força física dotada de agressividade de combate como instrumento dos exércitos. No caso masculino, valoriza-se a qualidade de vigor físico, surgindo, em decorrência, uma sexualidade imperativa, demonstração obrigatória de poder, e não como exercício da vontade do sujeito. Essa representação social do masculino contrasta com aquela do feminino, cujo imperativo é a reprodução biológica, o controle da sexualidade e a disciplina dos cuidados.

Essas representações indicam, de outro lado, que também os homens são alvo de naturalização no plano do conhecimento científico, e tal qual as mulheres, são reduzidos a uma dimensão biológica na qual imediatamente se acoplam as atribuições de gênero, culturalmente dadas enquanto corpos de determinado uso social.

Essas atribuições de gênero, que mais parecem ser essências naturais dos indivíduos deste ou daquele sexo do que construções socioculturais, terminam por conformar também a abordagem que as práticas assistenciais em saúde farão dos homens e das mulheres. Note-se a grande preocupação, nos serviços de saúde, em prontamente reparar a força física dos corpos masculinos e, como contrapartida, por aculturação dos próprios homens em sua naturalização, o valor maior que eles atribuem aos serviços de emergência e hospitais, que são os que mais procuram.

A crítica que o projeto integralidade em sua nova aproximação ora realiza não se dirige exatamente à eficácia desses serviços, embora também questione uma representação de assistência eficaz reduzida ao atendimento ao corpo físico e descuidada de uma aproximação intersubjetiva com os homens que procuram esses serviços. A crítica se dirige, sobretudo, à formulação ideológica e política que lhe é subjacente: sua exclusividade como potência de assistência e cuidados. E isto mesmo quando, diante das problemáticas de prevenção dos adoecimentos e principalmente das de promoção da saúde, essa abordagem reduzida à naturalização biomédica mostra nítidas insuficiências.

A pretensão crítica leva a sair da aproximação técnico-científica dos homens como indivíduos dotados de corpos de sexo masculino para abordá-los como sujeitos em exercícios de masculinidades (Schraiber, Gomes \& Couto, 2005), exercícios esses que delimitam o domínio de uso 
e significação de seus corpos. Todavia, se essa nova forma de abordar amplia o escopo do conhecimento, também torna presente a necessidade de se questionar a modalidade hegemônica de eficácia assistencial, como dito. Delimitar o que seria uma 'precisa intervenção' e uma 'intervenção eficaz', em uma atenção integral voltada para necessidades de saúde em função dos exercícios das masculinidades e das feminilidades, já estendendo a mesma questão para a integralidade em saúde na atenção às mulheres, é algo que ainda deve ser mais trabalhado.

Cabe aqui assinalar que, relativamente às mulheres, os homens não tiveram seu corpo, não enquanto corpo reprodutor, tomado pelas estratégias biopolíticas de controle e disciplina reprodutiva, não se constituindo, para eles, uma problemática de recuperação de domínio de sujeito nessa dimensão. A temática aqui tratará de uma liberdade do corpo reprodutor que se articule à responsabilidade individual e social. Vale dizer, trata-se da paternidade (Gomes, 1998; Schraiber, Gomes \& Couto, 2005) a ser exercida, assim, de forma mais interativa com a mulher e mais participativa nas questões do cuidado e educação dos filhos, cujo lema estaria na 'paternidade responsável'.

Se os homens não tiveram, na perspectiva da reprodução, seus corpos controlados e disciplinados tal como as mulheres, não se pode esquecer o que representa a operação redutora do corpo masculino à sua força física (força de trabalho de um corpo-máquina), para os processos de integração de cuidados que caminham na direção da promoção e prevenção da saúde.

Ou seja, se o que os caracteriza é a sua força motriz capacitante e impulsionadora para a produção e reprodução social pelo trabalho, há, de certa forma, um controle do corpo masculino. Um controle ao inverso das mulheres, em que não se valoriza a possibilidade de se cuidar, mas sim a não necessidade do cuidado contínuo, restando apenas a 'reposição de peças' quando elas já não estão dando conta das exigências do trabalho social. A promoção, a prevenção e o cuidado de si não serão, neste enfoque, valorizados como questão masculina, o que deverá ocorrer sob a perspectiva da atenção integral.

Da circulação mais livre do corpo masculino decorre também maior liberdade na esfera das relações afetivo-sexuais e da vida doméstica. É, assim, facultada, aos homens, grande circulação em exercícios da sexualidade. Além disso, esta liberdade também está alocada no interior de um padrão fixo de sexualidade, o heterossexual. Encontrar-se-á, 
portanto, novamente levando em conta a história das mudanças ocasionadas pela categoria gênero na saúde das mulheres, a saúde sexual como outra grande temática para o projeto da atenção integral também dos homens, ainda que com sentidos diversos.

Deve-se destacar, neste caso, em especial a relação entre o exercício da sexualidade e a interação afetiva, temática ainda não problematizada na saúde dos homens.

Reprodução e sexualidade, juntos, compõem os grandes temas da saúde da mulher até praticamente o final da década de 1990. Constituem também os grandes temas para a saúde dos homens. A violência, por sua vez, ainda que seja uma questão completamente articulada a esses temas, ainda encontra mais dificuldades de se incorporar, em ambos os casos. Adicionalmente, temas como 'cuidado' ou os da conexão entre a sexualidade e as interações mais simétricas de sujeitos afetivos, por referência a parcerias estáveis ou não, e que constituem reflexões críticas centrais sobre as relações de gênero e suas desigualdades, são ainda pouco desenvolvidos. Acolhê-los viria, sem dúvida, a acrescentar ainda mais qualificações de gênero na integralidade em saúde.

\section{Referências}

AROUCA, S. O Dilema Preventivista: contribuição para a compreensão e crítica da medicina preventiva. São Paulo, Rio de Janeiro: Editora Unesp, Editora Fiocruz, 2003.

AYRES, J. R. C. M. Epidemiologia e Emancipação. São Paulo: Hucitec, Abrasco, 1995.

AYRES, J. R. C. M. O cuidado, os modos de ser (do) humano e as práticas de saúde. Saúde e Sociedade, 13(3): 16-29, 2004.

BARSTED L. L. O campo político-legislativo dos direitos sexuais e reprodutivos no Brasil. In: BERQUÓ, E. (Org.). Sexo \& Vida: panorama da saúde reprodutiva no Brasil. São Paulo: Editora Unicamp, 2003.

BOURDIEU, P. A Economia das Trocas Simbólicas. São Paulo: Perspectiva, 1974.

BOURDIEU, P. Razões Práticas: sobre a teoria da ação. São Paulo: Papirus, 1996.

CAMPOS, G. de S. Os Médicos e a Política de Saúde. São Paulo: Hucitec, 1988.

CANGUILHeM, G. O Normal e o Patológico. 2. ed. Rio de Janeiro: ForenseUniversitária, 1982. 
CHAUÍ, M. de S. O que É Ideologia. São Paulo: Brasiliense, 1982. (Coleção Primeiros Passos, 13).

ClaVREUl, J. A Ordem Médica. São Paulo: Brasiliense, 1983.

CONTI, L. Estrutura social y medicina. In: ALOISI, M. et al. (Orgs.). Medicina y Sociedad. Barcelona: Libros de Confrontación, 1972.

CORREA, S. \& ÁVILA, M. B. Direitos sexuais e reprodutivos: pauta global e percursos brasileiros. In: BERQUÓ, E. (Org.). Sexo \& Vida: panorama da saúde reprodutiva no Brasil. São Paulo: Editora Unicamp, 2003.

D' OLIVEIRA, A. F. P. L. \& SENNA, D. M. Saúde da mulher. In: SCHRAIBER, L. B.; NEMES, M. I. B. \& MENDES-GONÇALVES, R. B. (Orgs.). Saúde do Adulto: programas e ações na unidade básica. São Paulo: Hucitec, 2000.

DESLANDES, S. F. (Org.). Humanização dos Cuidados em Saúde: conceitos, dilemas e práticas. Rio de Janeiro: Editora Fiocruz, 2006.

DONNANGELO, M. C. F. Medicina e Sociedade. São Paulo: Livraria Pioneira, 1975.

DONNANGELO, M. C. F. Saúde e sociedade. In: DONNANGELO, M. C. F. \& PEREIRA, L. Saúde e Sociedade. São Paulo: Livraria Duas Cidades, 1976.

FIGUEIREDO, W. S. Assistência à saúde dos homens: um desafio para os serviços de atenção primária. Ciência \& Saúde Coletiva, 10(1): 105-110, 2005.

FIGUEIREDO, W. S. Masculinidades e Cuidado: diversidade e necessidades de saúde dos homens na atenção primária, 2008. Tese de Doutorado, São Paulo: Faculdade de Medicina, Universidade de São Paulo.

FOUCAULT, M. O Nascimento da Clínica. Rio de Janeiro: Forense-Universitária, 1977.

FOUCAULT, M. Microfísica do Poder. 2. ed. Rio de Janeiro: Graal, 1984.

GARCÍA, J. C. Juan César García entrevista Juan César García. In: NUNES, E. D. \& GARCÍA, J. C. (Orgs.). As Ciências Sociais em Saúde na América Latina: tendências e perspectivas. Brasília: Opas, 1985.

GOMES, R. As questões de gênero e o exercício da paternidade. In: SILVEIRA, P. (Org.). Exercício da Paternidade. Porto Alegre: Artes Médicas, 1998.

GRAMSCI, A. Os Intelectuais e a Organização da Cultura. Rio de Janeiro: Civilização Brasileira, 1968.

ILLICH, I. A Expropriação da Saúde. Rio de Janeiro: Nova Fronteira, 1975.

KISS, L. \& SCHRAIBER, L. B. Temas médico-sociais e a intervenção em saúde: a violência contra mulheres no discurso dos profissionais. Ciência \& Saúde Coletiva, 16(3): 1.943-1.952, 2011. Disponível em: <www.abrasco.org.br.cienciaes audecoletiva/artigos/lista_artigos.php $>$. 
MENDES-GONÇALVES, R. B. Medicina e História: raíces sociales del trabajo médico. México: Siglo XXI, 1984.

MENDES-GONÇALVES, R. B. Tecnologia e Organização Social das Práticas de Saúde: características do processo de trabalho na rede estadual de Centros de Saúde de São Paulo. São Paulo, Rio de Janeiro: Hucitec, Abrasco, 1994.

MERHY, E. E. A Saúde Pública como Política: um estudo de formuladores de políticas. São Paulo: Hucitec, 1992.

NOGUEIRA, R. P. A ideologia médica neoliberal. Saúde em Debate, 15/16: 44-47, 1984.

NOGUEIRA, R. P. Do Físico ao Médico Moderno: a formação social da prática médica. São Paulo: Editora Unesp, 2007.

PAIM, J. S. Desafios para a Saúde Coletiva no Século XXI. Salvador: Edufba, 2007.

PAIM, J. S. A Reforma Sanitária Brasileira: contribuição para a compreensão e crítica. Salvador, Rio de Janeiro: Edufba, Editora Fiocruz, 2008.

PAIM, J. S. \& ALMEIDA FILHO, N. A Crise da Saúde Pública e a Utopia da Saúde Coletiva. Salvador: Casa da Qualidade, 2000.

PINHEIRO, R. \& MATTOS, R. A. (Orgs.). Os Sentidos da Integralidade na Atenção e no Cuidado a Saúde. Rio de Janeiro: IMS/Uerj, Abrasco, 2001.

PINHEIRO, R. \& MATTOS, R. A. (Orgs.). Construção da Integralidade: cotidiano, saberes e práticas em saúde. Rio de Janeiro: IMS/Uerj, Abrasco, 2003.

PINHEIRO, R. \& MATTOS, R. A. (Orgs.) Cuidado: as fronteiras da integralidade. Rio de Janeiro: IMS/Uerj, Abrasco, 2005.

POLACK, J. C. La Medicina del Capital. Madrid: Fundamentos, 1971.

ROSEN, G. A evolução da medicina social. In: NUNES, E. D. (Org.) Medicina Social: aspectos históricos e teóricos. São Paulo: Global, 1983.

ROSEN, G. Individuos enfermos y poblaciones enfermas. In: BUCK, C. et al. (Orgs.). El Desafio de la Epidemiología: problemas y lecturas seleccionadas. Washington: Organización Panamericana de la Salud, 1988. (OPS, Publicación Científica, 505).

SARTRE, J. P. Questão do método. In: PESSANHA, J. A. M. Sartre: vida e obra. 3. ed. São Paulo: Nova Cultural, 1987. (Coleção Os Pensadores).

SCHRAIBER, L. B. O Médico e seu Trabalho: limites da liberdade. São Paulo: Hucitec, 1993.

SCHRAIBER, L. B. Políticas públicas e planejamento nas práticas de saúde. Saúde em Debate, 47: 28-35, 1995.

SCHRAIBER, L. B. Equidade de gênero e saúde: o cotidiano das práticas no Programa de Saúde da Família do Recife. In: VILLELA, W. \& MONTEIRO, S. (Orgs.). 
Gênero e Saúde: Programa Saúde da Família em questão. Rio de Janeiro, São Paulo: Abrasco, UNFPA, 2005.

SCHRAIBER, L. B. O Médico e suas Interações: a crise dos vínculos de confiança. São Paulo: Hucitec, 2008.

SCHRAIBER, L. B.; GOMES, R. \& COUTO, M. T. Homens e saúde na pauta da saúde coletiva. Ciência \& Saúde Coletiva, 10(1): 7-17, 2005.

SIGERIST, H. E. Historia y Sociología de la Medicina. Bogotá: Guadalupe, 1974.

SILVA, J. M. Como estão as desigualdades em gênero no Programa Saúde da Família? In: VILlELA, W. \& MONTEIRO, S. (Orgs.). Gênero e Saúde: Programa Saúde da Família em questão. Rio de Janeiro: Abrasco, UNFPA, 2005.

TAVARES, A. H. A. et al. Relações de gênero no Programa Saúde da Família do Recife: diagnóstico de situação. Relatório final de pesquisa. Recife, São Paulo: Coordenadoria da Mulher da Prefeitura do Recife, USP-FM/DMP, SOS-Corpo, Fages/UFPE, 2004.

VIEIRA, E. M. A Medicalização do Corpo Feminino. Rio de Janeiro: Editora Fiocruz, 2002. (Coleção Antropologia e Saúde).

VILLELA, W. \& MONTEIRO, S. Atenção à saúde das mulheres: historicizando conceitos e práticas. In: VILLELA, W. \& MONTEIRO, S. (Orgs.). Gênero e Saúde: Programa Saúde da Família em questão. Rio de Janeiro: Abrasco, UNFPA, 2005. 


\title{
'Eu Não Sou Só Próstata, Eu Sou um Homem!' Por uma política pública de saúde transformadora da ordem de gênero
}

\author{
Benedito Medrado, Jorge Lyra e Mariana Azevedo
}

A frase 'Eu não sou só próstata, eu sou um homem!' foi produzida, durante um grupo focal, por um homem de 37 anos, residente em comunidade de baixa renda de São Paulo, no contexto de um estudo multicêntrico intitulado "Investigating the role of men in women's reproductive and sexual health" (Arrow, 2002). ${ }^{1} \mathrm{O}$ grupo focal aconteceu em 2000, mas este enunciado nos parece bastante atual diante da eminente institucionalização de uma política integral de atenção aos homens na saúde. A frase sintetiza um conjunto de aspectos conceituais e simbólicos que pretendemos explorar neste capítulo, de modo a contribuir para os esforços de implementação desta política.

Nosso objetivo é produzir uma breve revisão da maneira como estudos e intervenções sociais com homens e/ou sobre masculinidade vêm sendo desenvolvidos, no campo da saúde e direitos sexuais e reprodutivos,

\footnotetext{
1 No início dos anos 90, o International Reproductive Rights Research Action Group (IRRRAG) conduziu uma investigação qualitativa multicêntrica internacional que teve por objetivo identificar de que modo mulheres, de diferentes contextos socioculturais, compreendiam e vivenciavam as injunções de gênero no campo da sexualidade e da reprodução. Esta pesquisa evidenciou a necessidade de um estudo voltado à escuta das necessidades e demandas dos homens nesse campo. Assim, entre 2000 e 2001, foi realizado o estudo multicêntrico com homens, em cinco países: Brasil, Filipinas, Malásia, México e Nigéria. No Brasil, o trabalho foi desenvolvido em Pernambuco, Rio de Janeiro e São Paulo. Participaram da pesquisa um centro universitário de pesquisa e ação social - Programa Eicos, da Universidade do Estado do Rio de Janeiro (Uerj) -, um centro de pesquisa e educação - Fundação Carlos Chagas e quatro organizações não governamentais - SOS Corpo, Instituto Papai, Promundo e Coletivo Feminista Sexualidade e Saúde.
} 
para contribuir na definição e implementação de estratégias e programas de ação destinados à população masculina. Para isso, estruturamos nossos argumentos a partir de: 1) uma breve contextualização da trajetória política e conceitual dos debates que situam a masculinidade como construção de gênero e a perspectiva feminista como aporte teórico fundamental; 2) uma análise sobre a visibilidade de dados epidemiológicos sobre adoecimento e morte da população masculina como estratégia discursiva que justifica políticas, define prioridades e produz sujeitos; 3) uma leitura crítica sobre os investimentos recentes em torno da construção de um documento-marco para a política de saúde do homem, na interface com as políticas nacionais voltadas à mulher e aquelas dirigidas ao enfrentamento da homofobia.

\section{Masculinidade como campo de produção acadêmica e de reflexão política}

Buscando organizar essas produções, especialmente as publicadas entre 1995 e 2002, Robert (agora Rayween) Connell, ${ }^{2}$ Jeff Hearn e Michael Kimmel editaram, em 2005, o Handbook of Studies on Men and Masculinities. Nesse trabalho, os autores abordaram o que denominam "desenvolvimento do campo de pesquisas sobre masculinidades", focalizando o modo como os estudos e pesquisas têm construído esse campo: desde um olhar "mais amplo e global" até a expressão "mais íntima e pessoal" (Connell, Hearn \& Kimmel, 2005: 7). O campo é, segundo os autores, constituído a partir de produções que apresentam objetos em níveis distintos de análise:

1) a compreensão do modo como os homens entendem e expressam identidades de gênero;

2) as masculinidades como produtos de interações sociais dos homens com outros homens e com mulheres, ou seja, as masculinidades como expressões da dimensão relacional de gênero (que apontam tendências, desafios e desigualdades);

3) a organização social das masculinidades em suas inscrições e reproduções locais e globais;

2 Robert Connell submeteu-se a cirurgia para 'mudança de sexo' e, mais recentemente, vem publicando ou reeditando suas produções, com assinatura de Rayween (seu nome atual) ou simplesmente R. W. Connell. 
4) a dimensão institucional das masculinidades, ou seja, o modo como as masculinidades são construídas em (e por) relações e dispositivos institucionais.

No Brasil, os esforços de reflexão teórica e política sobre homens e masculinidades, a partir do enfoque de gênero, também ganham maior visibilidade a partir da década de 1990. Na primeira metade desta década, os estudos abordaram especialmente temas como 'identidade masculina' ou 'crise da masculinidade' (Nolasco, 1993; 1995; Hamawi, 1995; Jablonski, 1995). Localizam-se, portanto, no primeiro nível de análise descrito.

A partir da segunda metade dos anos 90, os investimentos teóricos e políticos buscam avançar nos demais níveis de análise, especialmente com o advento da Conferência Internacional de População e Desenvolvimento (Cairo, 1994) e da Conferência Internacional da Mulher (Pequim, 1995). Inauguram-se, assim, iniciativas de caráter teórico-político mais coletivo, a partir de eventos e publicações conjuntas, que tomam como ponto de partida o diálogo e as tensões entre as produções políticas e conceituais feministas e as produções acadêmicas que adotam gênero como conceito fundamental.

De fato, como destaca Sônia Corrêa (2002), o texto resultante da Conferência de População e Desenvolvimento do Cairo foi o primeiro a utilizar o termo 'gênero' em documentos oficiais das Nações Unidas. $\mathrm{O}$ objetivo, segundo a autora, era dar visibilidade às demandas por igualdade de gênero, equidade de gênero e 'empoderamento' das mulheres. Corrêa destaca, assim, o potencial "subversivo e de transformação" do conceito de gênero e aponta sua progressiva legitimação nas produções acadêmicas e no discurso político das sociedades e das instituições.

Essa tensão entre os usos conceituais e políticos da categoria gênero, orientou no Brasil a fundação, em 1995, do Grupo de Estudos sobre Sexualidade Masculina e Paternidade (Gesmap) - organizado pela Ecos Comunicação em Sexualidade, ONG de São Paulo, com apoio da Fundação Ford. Este grupo reunia mensalmente em torno de 20 profissionais, homens e mulheres, orientados por perspectivas, temas e campos de formação e atuação variados (ONGs, núcleos acadêmicos e centros de pesquisa e educação), que estavam, à época, iniciando estudos, pesquisas e projetos de intervenção sociopolítica voltados aos homens, nos campo da saúde e relações de gênero, sexualidade e reprodução. 
Entre 27 e 28 de abril 1998, o Gesmap organizou no Centro Universitário Maria Antônia, São Paulo, o primeiro Seminário Internacional Homens, Sexualidade e Reprodução, no qual foi lançada uma coletânea de textos produzidos pelos integrantes do grupo, intitulada Homens e Masculinidades: outras palavras (Arilha, Unbehaum \& Medrado, 1998). Na introdução da obra, os organizadores deixam claro que:

ao tematizarmos homens e masculinidades, não estamos 'inventando a roda', mas, ao contrário, estamos trilhando por caminhos já abertos em outros momentos, por outros atores sociais, nos planos teóricos e políticos, no Brasil e internacionalmente.

(...)

Portanto, em nossa perspectiva, torna-se vital compreender que a história política e acadêmica das feministas, gays e lésbicas tem uma influência direta na forma como as ideias sobre masculinidade se constituíram ao longo das últimas décadas, bem como na definição do conceito contemporâneo de masculinidade e no incentivo aos estudos sobre a condição masculina. No entanto, é necessária uma confluência dos estudos feministas, das reflexões sobre homossexualidade e homofobia e das práticas heterossexuais masculinas para compreender como homens e mulheres se relacionam e produzem sentido em torno da sexualidade e da reprodução em suas diversas culturas. (Arilha, Unbehaum \& Medrado, 1998: 15, 17)

Balizados em referências históricas do campo dos estudos de gênero e feminismo, investimentos coletivos como o Gesmap nos mostram que o ímpeto de promover mudanças sociais traz diversos desafios no campo conceitual e da formulação de ações públicas, exigindo reflexão e trocas constantes entre teoria e prática política. Indicam também que são necessários espaços que, de maneira contínua, fluida e afetiva, permitam uma produção dialógica e crescente de conhecimentos. Como consequência desse processo de reflexão teórico-política, foram fundados, em 1997, o Instituto Papai e, em 1998, o Núcleo de Pesquisas em Gênero e Masculinidades (Gema) da Universidade Federal de Pernambuco (UFPE). 
Nos últimos anos, a equipe e a estrutura do Instituto Papai foram ampliadas, o Gema adquiriu nova configuração ${ }^{3}$ e o debate sobre homens e masculinidades no Brasil foi-se consolidando a partir de espaços de troca de conhecimento, especialmente em seminários nacionais e internacionais, realizados em território brasileiro, tais como descritos a seguir:

- 2000 - Workshop: Homens e Políticas Públicas - reflexões e práticas sociais, em Recife, entre 10 e 11 de agosto. Organização: Instituto Papai e The John D. and Catherine T. MacArthur Foundation.

- 2001 - Seminário do $3^{\circ}$ Programa de Treinamento em Pesquisa na América Latina e Caribe/Prodir III. Tema: Homens e masculinidades, em Recife, entre 29 e 31 de janeiro. Organização: Fundação Carlos Chagas.

- 2002 - Conferência Internacional: Homens Jovens como Aliados na Promoção de Saúde e Equidade de Gênero, Rio de Janeiro, entre 27 e 30 de agosto. Organização: Promundo, Instituto Papai, OMS, UNFPA, Engenderhealth, Unicef, Unesco, entre outros. Presença de profissionais de 38 países de todos os continentes.

- 2003 - 2 ${ }^{\circ}$ Seminário Internacional: Homens, Sexualidade e Reprodução tempos, práticas e vozes, em Recife, entre 17 e 20 de junho. Organização: Instituto Papai, Fages/UFPE, Grupo Pegapacapá e Unicamp.

Reunião Técnica Internacional: O Papel dos Homens e Homens Jovens na Promoção da Equidade de Gênero, preparatória da $48^{a}$ sessão da Comissão sobre a Situação da Mulher (CSW), uma das comissões funcionais do Conselho Econômico e Social das Nações Unidas (Ecosoc), em Brasília/ DF, entre 21 e 24 de outubro. Organização: Secretaria Especial de Políticas para as Mulheres - Brasil e ONU.

Seminário Nacional: O Lugar dos Homens nas Agendas Políticas de Gênero, durante o V Fórum Social Mundial, em Porto Alegre, entre 23 a 28 de janeiro. Organização: Rede de Homens pela Equidade de Gênero.

- 2004 - Simpósio Nacional: Homens Jovens - participação juvenil, programas e políticas públicas, em Brasília, entre 26 e 28 de abril. Organização: Promundo, Instituto Papai, Ecos - Comunicação em Sexualidade, Opas.

Entre 1998-2004, o Gema constituiu-se como grupo de estudos e pesquisas, cujos integrantes eram oriundos de diferentes instituições. Desde 2005, passou a integrar o Programa de PósGraduação em Psicologia da UFPE, agregando estudantes de pós-graduação e graduação, envolvidos em projetos de pesquisa e intervenção política. 
- 2005 - 3o Seminário Nacional: Homens, Sexualidade e Reprodução. Tema: $\mathrm{O}$ direito à diversidade e à diferença na saúde reprodutiva, em Recife, entre os dias 24 e 26 de agosto de 2005. Organização: Instituto Papai, Fages/UFPE e Gema/UFPE.

- 2006 - 4 Seminário Nacional: Homens, Sexualidade e Reprodução. Tema: Homens, feminismo e políticas públicas em saúde, em Recife, de 20 a 22 de março. Organização: Instituto Papai, Gema/UFPE, Fages/UFPE, Rede Feminista Norte-Nordeste de pesquisas sobre Mulher e Relações de Gênero (Redor), Associação Brasileira de Psicologia Social (Abrapso).

- 2008 - Seminário \& Workshop Internacional: Políticas de Atenção a Homens Autores de Violência contra a Mulher, em Florianópolis, entre 22 e 23 de agosto. Organização: Margens/UFSC, Instituto Papai e Gema/UFPE.

$5^{\circ}$ Seminário Nacional: Homens, Gênero e Políticas Públicas, Recife, 22 a 24 de outubro. Organização: Instituto Papai e Gema/UFPE.

- 2009 - Simpósio Global: Engajando Homens pela Igualdade de Gênero, Rio de Janeiro, entre 30 de março e 3 de abril. Organização: Promundo, Instituto Papai, MenEngage Aliance, Save the Children - Sweden, United Nations Population Fund (UNFPA), White Ribbon Campaign (Canadá). Presença de profissionais de 79 países de todos os continentes.

Em linhas gerais, essa trajetória evidencia um foco prioritário desses encontros no campo amplo da saúde, sexualidade e reprodução, envolvendo sujeitos políticos distintos vinculados a instituições acadêmicas, organismos das Nações Unidas e organizações não governamentais que atuam com base em perspectivas feministas e/ou de gênero.

Como sujeitos políticos neste cenário, nosso interesse em particular que tem orientado nossas experiências de ação desenvolvida diretamente com homens - tem por base uma preocupação ética e política sobre os limites e possibilidades de incorporar experiências e aprendizagens de organizações não governamentais à organização de serviços de atenção à saúde, integrado ao modelo do Sistema Único de Saúde (Lyra, 2008).

Essa preocupação se deve ao fato de que, até o momento, experiências concretas com homens, em diferentes idades, têm sido desenvolvidas prioritariamente por organizações da sociedade civil, com recursos de fundações privadas e não lucrativas (Ecos, 2001; Lyra, 2008). Essas iniciativas, no entanto, esbarram em diversos obstáculos, entre os quais: 1) a falta de preparo dos próprios profissionais de saúde - tanto homens como mulheres - para atender à clientela masculina; 2) a inexistência de material educativo específico; 3) a ausência de uma agenda política referenciada nas atuais 
propostas do movimento feminista; 4) a falta de interesse da maioria dos homens em cuidar da própria saúde (Oliveira, Bilac \& Muszkat, 2000) e se envolver no movimento pelos direitos sexuais e reprodutivos. Além disso, ainda são notórios os poucos recursos governamentais aportados para formular e executar políticas e programas desta natureza (Arilha, 1999; ToneliSiqueira, 2000).

Assim, em 2004, transformamos essa preocupação em um projeto de pesquisa-ação institucional, intitulado Homens nos Serviços Públicos de Saúde: rompendo barreiras culturais, institucionais e individuais, com o objetivo geral de promover a inserção dos homens em programas de saúde reprodutiva/saúde integral de hospitais de referência em três capitais brasileiras de regiões distintas - Recife, São Paulo e Florianópolis -, por meio da capacitação de profissionais e elaboração de estratégias de comunicação, embasadas em pesquisa-diagnóstico e avaliação, com o apoio do Fundo de População das Nações Unidas (Fnuap), Ministério da Saúde (MS)/Área Técnica da Saúde da Mulher (ATSM) e Fundação Ford.

Esse projeto foi concluído em 2006. Os resultados evidenciaram, em linhas gerais, que o sistema de saúde progressivamente vem pensando os homens como uma população com necessidades específicas, reconhece que a masculinidade é uma 'construção social', porém ainda não adota o referencial de gênero em suas análises ou propostas. $\mathrm{O}$ diálogo também com o feminismo é ainda incipiente. Ao mesmo tempo, o desenvolvimento do projeto evidenciou que serviços ou programas circunscritos a unidades de média complexidade respondem apenas parcialmente às necessidades e demandas em saúde da população masculina, uma vez que, para o desenvolvimento de uma atenção integral aos homens na saúde, é necessário atuar junto aos homens também na perspectiva da promoção à saúde, exigindo uma atuação orientada à atenção básica.

De 2006 a 2009, desenvolvemos uma experiência de pesquisa-ação, novamente em três capitais brasileiras de regiões distintas (Recife, Florianópolis e São Paulo), na rede de atenção básica à saúde, especialmente junto aos Programas de Saúde da Família (PSF) e o Programa de Agentes Comunitários de Saúde (Pacs), envolvendo profissionais, agentes comunitários de saúde, usuários e 'potenciais usuários' ${ }^{4}$ com o apoio da Agência Internacional de Desenvolvimento Canadense (Cida).

\footnotetext{
4 Usamos a terminologia 'potenciais usuários' tendo em vista que os homens que identificamos nas três capitais ainda têm uma procura relativamente baixa a unidades básicas de saúde, não se constituindo necessariamente como usuários, embora residam nas circunvizinhanças das unidades de saúde que tomamos como ponto focal. Vale salientar que, por vezes, tivemos de lançar mão de estratégias alternativas para acessá-los, a partir de busca ativa fora dos serviços específicos.
} 
$\mathrm{Na}$ mesma medida em que temos acumulado experiências e conhecimentos a partir dessas iniciativas que aliam pesquisa e intervenção política, temos buscado desenvolver reflexões teóricas com vistas à construção de um necessário marco político-conceitual que os auxilie a compreender a dinâmica de gênero em que se inscrevem as experiências dos homens e a institucionalização de masculinidades.

Este exercício busca avançar a partir das preocupações apresentadas por Estela Aquino (2006), para quem as reflexões teóricas e epistemológicas sobre as relações de gênero e saúde no campo da saúde coletiva ainda são escassas, e a incorporação da abordagem de gênero na epidemiologia tem sido lenta e enfrenta dilemas teóricos que geram obstáculos ao uso de 'gênero' como categoria analítica e não apenas como substituição da variável 'sexo'. Dificuldade maior é apontada pela autora à incorporação de outras categorias sociais, tais como 'raça/etnia' e 'idade'. Só mais recentemente e de distintas formas é que as intersecções de raça/etnia e idade/geração são incorporadas ao debate de saúde, classe e gênero.

Uma síntese dos nossos esforços é apresentada em artigo publicado na revista Estudos Feministas, intitulado "Por uma matriz feminista de gênero para os estudos sobre homens e masculinidades" (Medrado \& Lyra, 2008). Em síntese, com o objetivo de contribuir para os estudos e pesquisas sobre homens e masculinidades, apresentamos um marco conceitual de gênero, a partir de uma matriz que dialoga com produções feministas e se organiza em quatro eixos: 1) o sistema sexo/gênero; 2) a dimensão relacional $_{i} 3$ ) as marcações de poder $\left.{ }_{i} 4\right)$ a ruptura da tradução do modelo binário de gênero nas esferas da política, das instituições e das organizações sociais.

O primeiro exercício para definição de nosso marco conceitual consiste em reafirmar a necessidade de desnaturalizar as prescrições e práticas sociais atribuídas a (e incorporadas e naturalizadas por) homens e mulheres, consideradas marcações masculinas e femininas. Não se trata apenas de diferenciar sexo (como corpo) de gênero (como culturas). A leitura sobre o sistema sexo/gênero que adotamos não reifica essa dicotomia natureza-cultura, mas busca compreender os usos e efeitos que práticas sociais (econômicas, políticas, científicas etc.) produzem a partir do exercício constante de oposição ou de busca de similitude entre os dois sexos. Nosso objeto de preocupação é a complexa teia que define as relações de gênero, que nos aponta, de forma subversiva e transformadora, mais para a diversidade do que para a diferença, como resposta à dicotomia e à desigualdade. 
O segundo componente do marco conceitual é o reconhecimento da dimensão relacional que o conceito de gênero trouxe para nosso vocabulário analítico (Scott, 1995). Em síntese, gênero não pode ser pensado como entidade em si, mas como jogo entre construções interdependentes. Nessa perspectiva, Barbieri (1992: 114) defende que não podemos estudar ou intervir exclusivamente junto às mulheres, pois o conceito de gênero é mais amplo, e, sendo assim, "faz-se necessária uma análise em todos os níveis, âmbitos e tempos, das relações mulher-homem, mulher-mulher, homem-homem para se alcançarem maiores resultados". Para isso, precisamos produzir reflexões sobre a construção de masculinidades e feminilidades que vão além da vitimização de alguns (mulheres) e da culpabilização de outros (homens).

Afinal, reconhecer a dimensão relacional do gênero possibilita desconstruir principalmente os argumentos culpabilizantes sobre os homens que caracterizam o discurso de parte do movimento feminista e que ainda se faz presente, direta ou indiretamente, nas produções acadêmicas contemporâneas. Como destaca Medrado (1997), ao invés de procurar os culpados, é necessário identificar como se institucionalizam e como se atualizam as relações de gênero, possibilitando efetivamente transformações no âmbito das relações sociais 'generificadas', ou seja, orientadas pelas desigualdades de gênero. Isso não implica um processo de desresponsabilização individual, mas reconhecer que as análises que agregam a dimensão relacional do conceito de gênero permitem compreender ou interpretar uma dinâmica social que hierarquiza as relações entre o masculino e o feminino não apenas entre homens e mulheres, mas em práticas de homens e de mulheres. Faz-se necessário considerar também as categorias de raça/etnia, idade, sexualidade e condição socioeconômica.

O terceiro componente de nosso marco conceitual é o reconhecimento de gênero como categoria útil para análise das relações e jogos de poder. Segundo Joan Scott (1995: 88), "o gênero é um campo primeiro no interior do qual, ou por meio do qual, o poder é articulado". Miguel Vale de Almeida (1996), por sua vez, argumenta que masculinidade e feminilidade são metáforas de poder e de capacidade de ação que orientam valores e práticas sociais de homens e mulheres. Portanto, o debate sobre as relações de poder que inscrevem masculinidades e feminilidades em nossa cultura é fundamental. 
O quarto componente resgata o quarto nível de análise proposto por Connell, Hearn e Kimmel (2005), apresentado no início deste texto. A partir da leitura complexa proposta por Joan Scott sobre as dimensões simbólica, normativa, identitária e política de gênero, focalizamos a necessidade de ruptura da tradução do modelo binário e fixo de masculino e feminino no nível da política, das instituições e organizações sociais.

Essa matriz poítico-conceitual está alicerçada em estudos que adotam uma concepção feminista de gênero: construção social que engendra e legitima o poder masculino. ${ }^{5} \mathrm{O}$ ponto de partida de nossas reflexões sobre homens e masculinidades, baseadas nesse marco conceitual, é que não existe uma única masculinidade e que não é possível falar em formas binárias que supõem a 'di-visão' entre formas hegemônicas e subordinadas. Tais formas dicotômicas baseiam-se nas posições de poder social dos homens, mas são assumidas de modo complexo por homens particulares, que também desenvolvem relações diversas com outras masculinidades.

Investigar sobre masculinidades significa não apenas apreender e analisar os signos e significados culturais disponíveis sobre o masculino, mas também discutir preconceitos e estereótipos e repensar a possibilidade de construir outras versões e sentidos. Situa-se, portanto, nos usos e efeitos que orientam os jogos de discursos e práticas, ou mais precisamente práticas discursivas, que tendem a transformar diversidade em desigualdade.

Diante dessa análise crítica sobre o 'estado da arte' de estudos e pesquisas sobre homens e masculinidades, especialmente no contexto da saúde, sexualidade e reprodução, ratificamos que é preciso romper com modelos que, geralmente, reafirmam a diferença e que nos permitem somente explicar como ou por que as coisas assim são, mas que não apontam contradições, fissuras, rupturas, brechas, frestas etc. que nos permitam visualizar caminhos de transformação progressiva e efetiva. Apostamos na necessidade de abrir espaços transgressores para novas construções teóricas que resgatem o caráter plural, polissêmico e crítico das leituras feministas com vistas, por exemplo, a uma interpretação mais criativa de dados epidemiológicos sobre a saúde, ou mais precisamente morbidade e mortalidade dos homens.

5 Para construir essa matriz, tomamos por base especialmente as produções de Vale de Almeida $(1995,1996)_{i}$ Lyra (1997); Medrado (1997); Figueroa-Perea (1998, 2003); Arilha, Unbehaum \& Medrado (1998); Arilha (1999, 2005). 


\section{A visibilidade de dados epidemiológicos como estratégia discursiva que justifica políticas, define prioridades e produz sujeitos}

Desde a década de 1990, têm-se empreendido esforços no sentido de dar visibilidade a informações sobre morbidade e mortalidade da população masculina no Brasil. O primeiro estudo epidemiológico brasileiro de grande amplitude sobre a população masculina foi publicado por Ruy Laurenti e colaboradores em 1998. Com o título de "Perfil epidemiológico da saúde masculina na região das Américas: uma contribuição para o enfoque de gênero", a pesquisa foi realizada em 16 países, ${ }^{6}$ a partir da análise de diferentes fontes.

Em linhas gerais, este estudo nos informa que, desde a primeira vez em que os países passaram a calcular sistematicamente a idade média de suas populações, tem-se registrado uma diferença entre os sexos: os homens sempre apresentaram idade média inferior à das mulheres. Do mesmo modo, analisando o diferencial de mortalidade segundo sexo e idade, percebe-se nitidamente uma sobremortalidade masculina em todos os grupos etários, principalmente nos mais jovens.

A pesquisa ressalta, ainda, que os homens têm ocupado, ao longo dos anos, a infeliz primeira colocação em diferentes estatísticas: primeiro lugar em número de homicídios; maiores taxas de suicídio e de morte por acidentes, principalmente envolvendo veículos a motor; maiores índices de problemas gerados pelo uso excessivo de bebida alcoólica e drogas psicotrópicas ilícitas; principais autores de roubos e assaltos e, consequentemente, maior população penitenciária, além de grandes protagonistas de agressões físicas, seja contra outros homens, mulheres ou crianças, em âmbitos domésticos ou públicos. Essas estatísticas alinhamse a uma constante histórica: a menor expectativa de vida dos homens em relação às mulheres, a o nascer e em idades superiores. Essa sobremortalidade masculina, em números absolutos e coeficientes, tem sido informada em pesquisas posteriores (Laurenti et al., 1998; Gomes, 2003; Laurenti, Mello Jorge \& Gotlieb, 2005).

Assim, como afirma Aquino (2006), a partir da década de 1990, os homens passaram a ser incluídos nas pesquisas em saúde coletiva como

6 Argentina, Barbados, Brasil, Canadá, Chile, Colômbia, Costa Rica, Cuba, Estados Unidos, Guatemala, Jamaica, México, Panamá, Porto Rico, Uruguai e Venezuela. 
categoria empírica. Ao mesmo tempo, abordagens críticas aos modelos de masculinidade hegemônica somaram-se aos esforços de desconstrução de essencialismos.

Porém, como destaca Pedro Paulo Oliveira (2004), a visibilidade dos custos da cultura machista para os homens tem sido amplamente utilizada por estudiosos que se dedicam a pesquisar os homens e as masculinidades, gerando uma leitura vitimária sobre eles. Segundo o autor:

Para apresentar o homem como vítima, muitos recorrem às estatísticas referentes a homicídios, uso de álcool e drogas, acidentes automobilísticos, incidência de doenças, expectativa de vida etc. Tais estatísticas corroborariam a inusitada afirmação de que o verdadeiro sexo frágil é na verdade o homem e não a mulher, além de evidenciarem o peso do fardo que as prescrições sociais impõem ao gênero masculino. (Oliveira, 2004: 90)

Do nosso ponto de vista, o uso retórico dessas informações não apenas criou uma leitura vitimária sobre os homens, mas, antes de tudo, forjou um sujeito para as políticas públicas. Para além do homem que é responsável pelo adoecimento (ou obstáculo à saúde) das mulheres e para além do homem que tradicionalmente ocupa postos de poder nos sistemas que orientam políticas em saúde, produz-se o homem que necessita de atenção especial.

Todavia, só quase uma década depois, em 2006, é publicada uma síntese sobre o homem e as políticas públicas de saúde: Indicadores e Dados Básicos para a Saúde: IDB 2006 Brasil. ${ }^{7}$ Esta publicação, produzida pela Rede Interagencial de Informações para a Saúde (Ripsa) - composta pelo Instituto Brasileiro de Geografia e Estatística (IBGE), Instituto de Pesquisas Econômicas e Sociais (Ipea), Fundação Seade e Ministério da Saúde, entre outras instituições, - informa que homens e mulheres vivem, hoje, mais do que na década de 1980.

Assim, entre 1980 e 2005, a vida média dos homens, por exemplo, passou de 59,7 para 68,4 anos, ou seja, em duas décadas e meia, houve, para os homens, um ganho aproximado de dez anos na esperança de vida ao nascer. Porém, destaca-se que a diferença entre homens e mulheres vem se mantendo, ou seja, há uma expectativa de vida ao nascer

7 Para mais informações, consulte o site: <http://tabnet.datasus.gov.br/cgi/idb2006/ matriz.htm>. 
expressivamente maior para o sexo feminino, desde 1980, com diferença média de aproximadamente sete anos, conforme se verifica no Gráfico 1.

Gráfico 1 - Esperança de vida ao nascer segundo o sexo. Brasil - 19802005

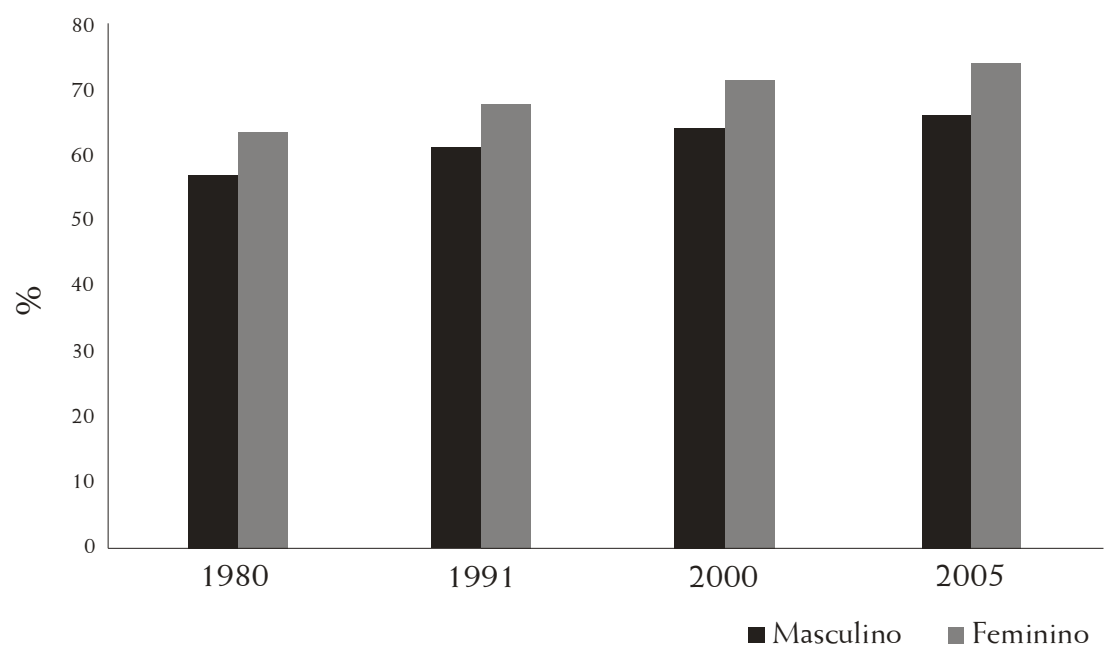

Fonte: Com base em dados do IBGE (Ripsa, 2007).

No que se refere aos dados sobre adoecimento, como mostramos anteriormente, o IDB 2006 destaca que as lesões decorrentes de causas externas motivaram parcela considerável $(28,4 \%)$ da hospitalização de homens de 15 a 29 anos em 2005. Os transtornos mentais também pesam na hospitalização de homens jovens e adultos e estão associados ao uso/ abuso de álcool (mais de 1/3 dos casos). Na idade de 30 a 59 anos, foram mais frequentes $(15,3 \%)$ as doenças do aparelho digestivo, superando ligeiramente as doenças do aparelho circulatório $(14,9 \%)$ e as causas externas (14,3\%). A partir dos 60 anos, predominaram as doenças dos aparelhos circulatório $(28,6 \%)$ e respiratório $(18,4 \%)$, despontando as neoplasias como quarta causa de internação $(8,8 \%)$ (Quadro 1). 
Quadro 1 - Principais causas de internação hospitalar no SUS em homens segundo faixas etárias selecionadas. Brasil - 2005

\begin{tabular}{|c|c|c|c|c|c|}
\hline Faixa etária & $1^{\mathrm{a}}$ causa & $2^{a}$ causa & $3^{\mathrm{a}}$ causa & $4^{\mathrm{a}}$ causa & $5^{\mathrm{a}}$ causa \\
\hline 15 a 29 & $\begin{array}{c}\text { Causas externas } \\
(28,4 \%)\end{array}$ & $\begin{array}{c}\text { Doenças do } \\
\text { aparelho } \\
\text { digestivo } \\
(11,9 \%)\end{array}$ & $\begin{array}{c}\text { Infecciosas } \\
(9,9 \%)\end{array}$ & $\begin{array}{c}\text { Doenças do } \\
\text { aparelho } \\
\text { respiratório } \\
(9,8 \%)\end{array}$ & $\begin{array}{c}\text { Transtornos } \\
\text { Mentais } \\
(8,2 \%)\end{array}$ \\
\hline 30 a 59 & $\begin{array}{c}\text { Doenças do } \\
\text { aparelho } \\
\text { digestivo } \\
(15,3 \%)\end{array}$ & $\begin{array}{l}\text { Doenças do } \\
\text { aparelho } \\
\text { circulatório } \\
(14,9 \%)\end{array}$ & $\begin{array}{l}\text { Causas } \\
\text { externas } \\
(14,3 \%)\end{array}$ & $\begin{array}{l}\text { Doenças do } \\
\text { aparelho } \\
\text { respiratório } \\
(9,3 \%)\end{array}$ & $\begin{array}{c}\text { Transtornos } \\
\text { Mentais } \\
(9,0 \%)\end{array}$ \\
\hline Mais de 60 & $\begin{array}{c}\text { Doenças do } \\
\text { aparelho } \\
\text { circulatório } \\
(28,6 \%)\end{array}$ & $\begin{array}{c}\text { Doenças do } \\
\text { aparelho } \\
\text { respiratório } \\
(18,4 \%)\end{array}$ & $\begin{array}{c}\text { Doenças do } \\
\text { aparelho } \\
\text { digestivo } \\
(10,9 \%)\end{array}$ & $\begin{array}{c}\text { Neoplasias } \\
\text { (tumores) } \\
(8,8 \%)\end{array}$ & $\begin{array}{c}\text { Doenças } \\
\text { infecciosas } \\
(6,6 \%)\end{array}$ \\
\hline
\end{tabular}

Fonte: Com base em dados do Ministério da Saúde/SAS/SIH-SUS (Ripsa, 2007).

Gráfico 2 - Percentual de óbitos por sexo segundo a faixa etária. Brasil - 2004

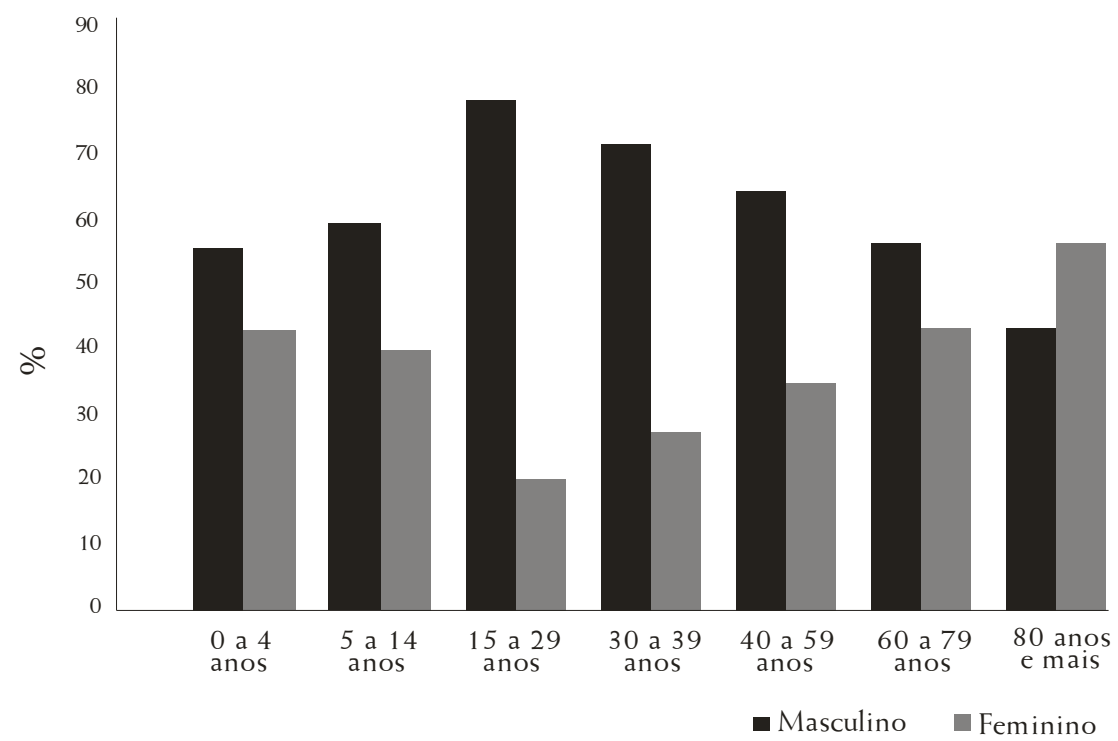

Fonte: Com base em dados do Ministério da Saúde/SVS/SIM (Ripsa, 2007).

Além disso, a publicação do IDB 2006 informa que os homens predominam entre os nascimentos vivos ( $5 \%$ a mais de meninos, ao nascer). 
Todavia, como se pode observar no Gráfico 2, os homens apresentaram, em 2004, sobremortalidade em todas as faixas etárias, com exceção do grupo a partir de 80 anos. ${ }^{8} \mathrm{O}$ excedente de mortes masculinas é ainda mais acentuado nos grupos etários de 15 a 29 (80\%) e de 30 a 39 anos (73\%).

No que se refere aos dados sobre mortalidade (Gráfico 3), as cinco principais causas de morte dos homens jovens (15-29 anos) são por fatores externos (76\% dos óbitos totais nessa idade), com destaque para agressões e acidentes de transporte. Entre os homens adultos (30-59 anos), a distribuição das causas é mais homogênea, preponderando causas externas (especialmente agressões e acidentes de transporte) e doenças do aparelho circulatório (doenças do coração e cerebrovasculares). Entre os homens idosos (mais de 59 anos), as causas externas não aparecem entre as principais, destacando-se as doenças do aparelho circulatório, que representam mais de um terço das mortes.

Gráfico 3 - Mortalidade proporcional (\%) pelas principais causas no sexo masculino em faixas etárias selecionadas. Brasil - 2004

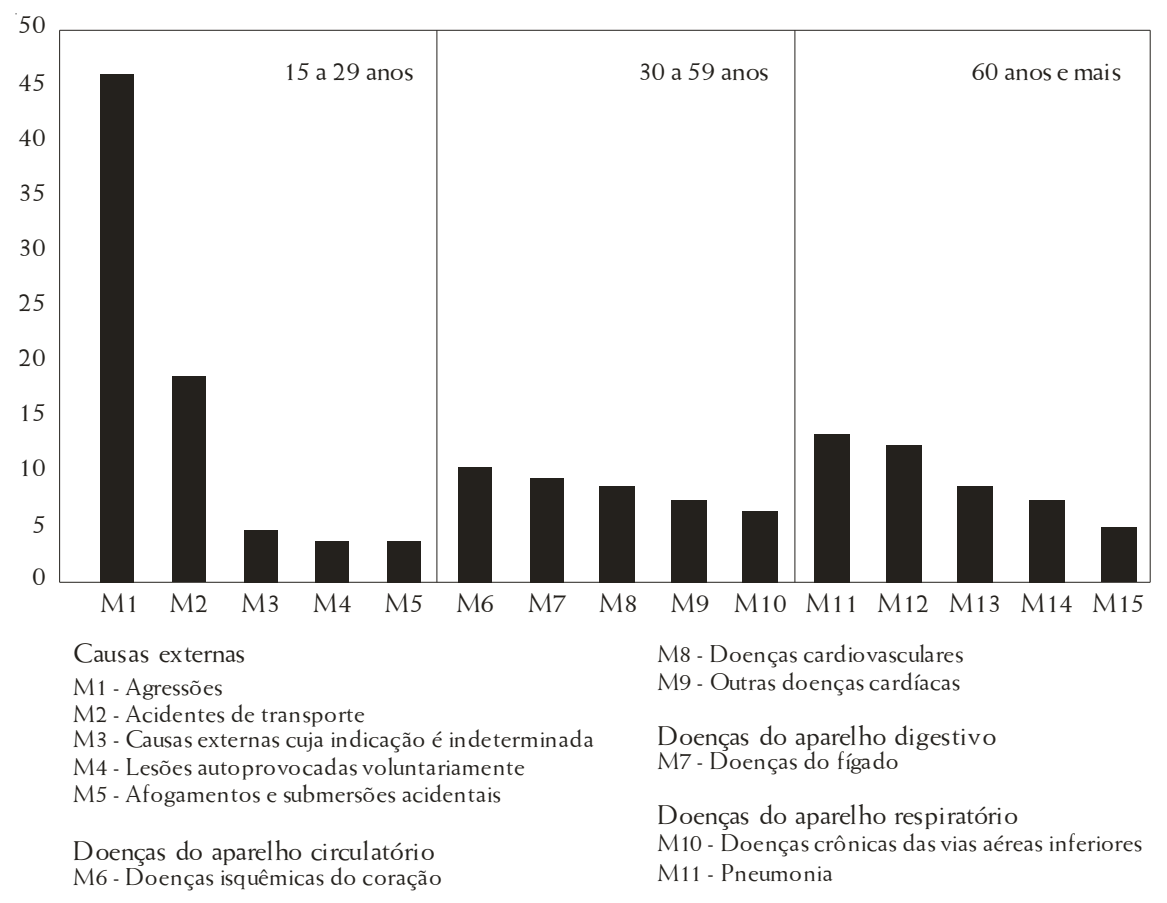

Fonte: Com base em dados do Ministério da Saúde/SVS/SIM (Ripsa, 2007).

8 Observa-se que há, no Brasil, uma população majoritária de mulheres com idade superior a 80 anos, o que pode justificar a sobremortalidade feminina nesta faixa etária. 
O IDB informa que, desconsiderando as faixas etárias, no conjunto, as principais causas de morte dos homens brasileiros são as doenças do aparelho circulatório, seguidas das neoplasias e das causas externas.

Porém, chama-nos a atenção a significativa diferença entre homens e mulheres no que se refere às mortes por causas externas (que incluem especialmente homicídios e acidentes de transporte). Segundo publicação da Secretaria de Vigilância em Saúde do Ministério da Saúde - SVS/MS (Brasil, 2006), em 2004 foram notificados, pelo Sistema de Informação sobre Mortalidade (SIM), 127.470 óbitos por causas externas. Deste número, 107.032 mortes (84\%) referem-se a homens (Ripsa, 2007). ${ }^{9}$

Fazendo ainda uma análise dos dados de 2004 relativos às mortes por causas externas entre os homens, por idade, constata-se a acentuada predominância dos óbitos por agressões nas faixas situadas entre 15 e 39 anos (Gráfico 4). Os acidentes de transporte também têm uma participação significativa, sendo a segunda principal causa externa de morte nesse grupo etário.

Gráfico 4 - Distribuição percentual dos óbitos masculinos por causas externas selecionadas segundo as faixas etárias. Brasil - 2004

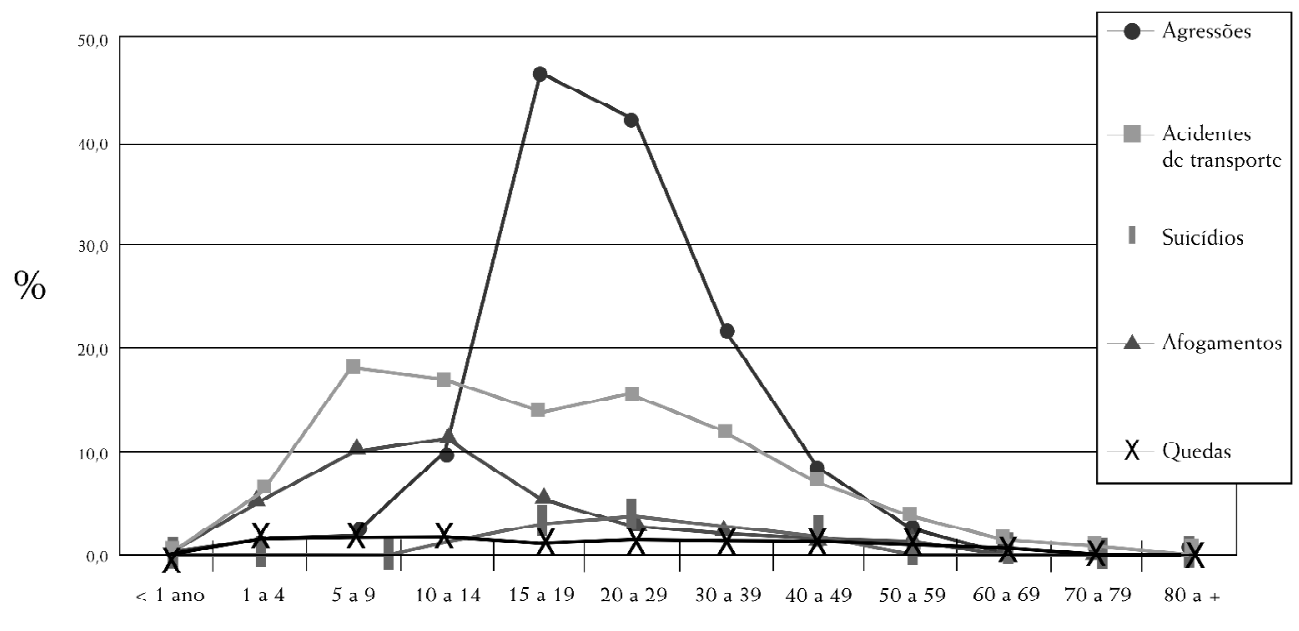

Faixa etária

Fonte: SVS/MS (Brasil, 2006).

9 As microrregiões com taxas mais elevadas se situam em áreas litorâneas do sul da Bahia até o sul de São Paulo; no interior pernambucano e noroeste da Bahia ${ }_{i}$ nos estados de Mato Grosso do Sul e de Mato Grosso; e em áreas de expansão na região Norte, como Roraima e sul do Pará. 
Ao mesmo tempo, de acordo com informações da SVS/MS, esse homem atingido por causas externas é predominantemente de 'raça negra' (somando os valores das pessoas que se declaram de cor/raça parda e preta), em todas as regiões do país, conforme ilustra o Gráfico 5.

Gráfico 5 - Taxa padronizada de homicídios* no sexo masculino segundo raça/cor autorreferida por região. Brasil - 2004

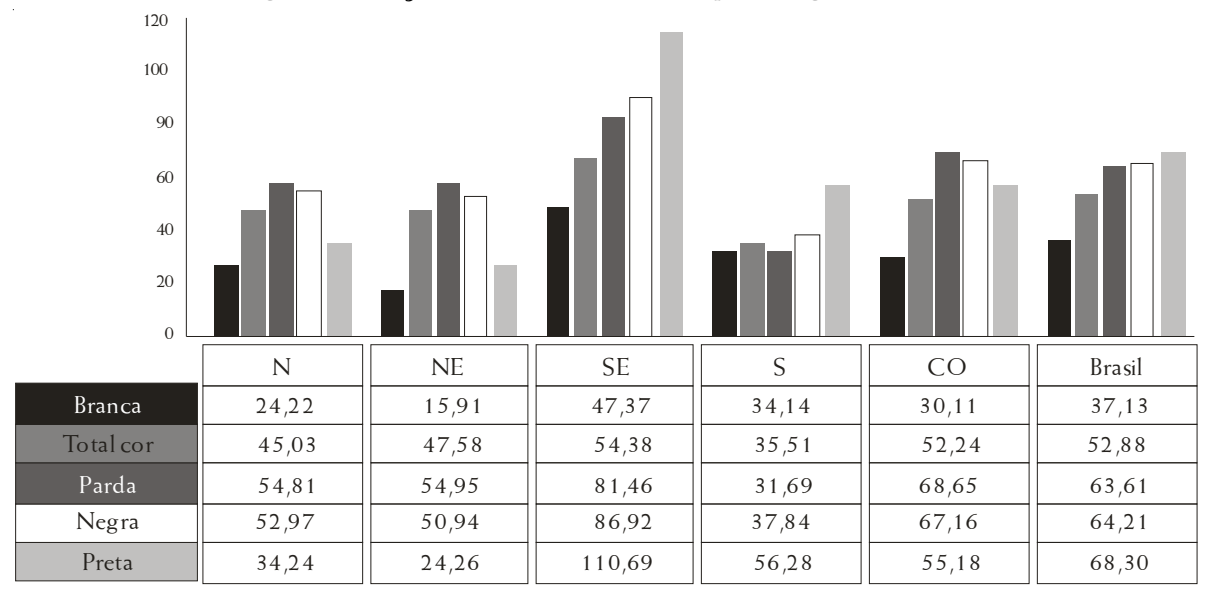

* Óbitos por 100.000 habitantes.

Fonte: SVS/MS/SIM (Brasil, 2006).

Como destaca Maria Inês Barbosa (1998), cabe ao homem negro o maior ônus de uma sociedade que se organiza a partir da ordem de classe, gênero e raça, uma vez que este se configura como antítese do modelo hegemônico. Assim, ela pergunta, em outras palavras: por que o racismo impede o homem negro de cumprir, de modo pleno, o modelo masculino desejável? A partir de questionamentos como este, Luiz Eduardo Batista (2005), em uma das poucas pesquisas sobre masculinidade, raça/cor e saúde, analisa registros de óbitos do estado de São Paulo, do ano de 1999. Segundo ele, as taxas de mortalidade entre os homens negros são maiores do que as dos brancos, especialmente na faixa etária entre 15 e 29 anos.

Em suma, as informações em saúde no Brasil, sejam de pesquisas epidemiológicas, demográficas ou oriundas da sistematização de dados com o objetivo de produzir subsídios para políticas públicas - sintetizados, por exemplo, em Indicadores e Dados Básicos para Saúde (Ripsa, 2007) -, ressaltam uma preocupação importante sobre as mortes por causas externas entre homens e nos apresentam um novo sujeito para as políticas públicas em saúde: o homem, jovem, negro e pobre. 
As informações sobre adoecimento e morte dos homens não constituem necessariamente uma novidade, considerando-se que têm sido apresentadas, na literatura, como tendência crônica e não como incidente agudo. Porém, chama-nos a atenção o fato de essas informações não terem sido ainda incorporadas, em sua complexidade, na construção de políticas públicas em saúde no nosso país.

$\mathrm{Na}$ nossa perspectiva, a formulação das políticas públicas em saúde no Brasil tem tido um olhar parcial para a visibilidade produzida pelos estudos epidemiológicos. A dimensão de gênero e raça, fortemente evidente nos dados das pesquisas, é sempre referida de maneira enfática quando se pensam as políticas públicas em saúde para a população jovem e pobre, mas as ações estruturais para a transformação desta condição social são negligenciadas (Longhi, 2008). A perspectiva das políticas públicas para a questão da violência urbana, por exemplo, adota muito mais um caráter repressivo com aumento do rigor das leis do que ações de prevenção e promoção da saúde visando a uma crítica à cultura machista e à ressignificação das relações de poder.

Além disso, como destaca Romeu Gomes (2008), não podemos perder de vista a perspectiva relacional de gênero. A saúde do homem, como ele bem afirma, não só pode ser pensada a partir de discussões sobre o perfil epidemiológico da morbimortalidade masculina, mas também para enfatizar aspectos culturais que podem comprometer a saúde de segmentos populacionais masculinos.

Para compreender essas questões, é importante resgatar as reflexões sobre a construção de uma política pública, apresentadas por Adriana Viana (1996) em seu artigo de revisão de literatura. A autora traz as contribuições de John Kingdon (1984) sobre três tipos de agenda pública:

1) sistêmica ou não governamental - organizada a partir da apresentação de um conjunto de assuntos que são há muito tempo preocupações do país, sem contudo receber a devida atenção do governo;

2) governamental - orientada pelas análises da gestão pública em relação aos problemas que merecem atenção do governo;

3) de decisão - baseada em análises sobre demandas e necessidades que exigem tomada de decisão.

Kingdon (1984) ressalta que um assunto pode sair da agenda sistêmica para a governamental quando existem eventos dramáticos ou crises ou 
quando há influência de um quadro de indicadores ou acúmulo de informações e experiências. Para compreender essa transição, é necessário identificar os atores ou participantes ativos - governamentais e não governamentais - e o processo - definido a partir das características dos orgãos, das instituições e dos aparelhos vinculados à produção de políticas públicas - pelo qual algumas alternativas e itens se tornam proeminentes.

Por ora, vale reafirmar aqui nosso pressuposto de que não é neutra a forma como são definidos os instrumentos, produzidos os registros e analisados os dados demográficos e as estatísticas especiais (vitais, educacionais, de saúde, de trabalho). Ou seja, ela tanto reflete como participa da construção social de um fenômeno (problema, questão, demanda, necessidade) que justifica a necessidade de uma política.

A quantificação, em particular, é ainda um dos instrumentos de maior poder retórico no contexto discursivo de formulação de políticas públicas. $\mathrm{O}$ uso da quantificação (argumentos numéricos) em debates científicos e/ou no desenho e implementação de políticas públicas destaca, frequentemente, a precisão e objetividade dos números em detrimento do 'achismo' e imprecisão dos argumentos verbais (Potter \& Wetherell, 1991). Entretanto, não se trata apenas de entender o uso que é feito dos números, mas de como um discurso, baseado em números, legitima e produz realidades e sujeitos (Spink \& Menegon, 1999).

Do mesmo modo, a invisibilidade ou falta de informações é também indicadora e produtora de verdades. Como afirma Fúlvia Rosemberg (1997), as imprecisões conceituais, a ausência de dados ou a superabundância de informações estatísticas participam do processo de construção social, por exemplo, das categorias 'negros', 'mulheres que trabalham fora', 'meninos de rua', 'prostituição infantojuvenil', 'portadores de deficiência', 'gravidez na adolescência', entre outras. ${ }^{10}$

Todavia, os organismos que dão visibilidade a dados demográficos e estatísticas especiais, no contexto da formulação de políticas públicas, não são surdos às pressões dos movimentos sociais e da comunidade acadêmica. Um exemplo marcante, nos últimos anos, é a convocação de representantes dessas instâncias, pelo IBGE e outros órgãos, para as reuniões de aprimoramento de suas pesquisas e dos respectivos instrumentos de coleta.

10 Encontramos ricas discussões sobre essas categorias demográficas em trabalhos tais como: Bruschini e Madeira (1983), Andrade e Rosemberg (1997), Piza e Rosemberg (1999). 
Pressões de pesquisadores e ativistas sociais, por exemplo, levaram a Pesquisa Nacional por Amostra de Domicílios (Pnad), a partir de 1987, a coletar, anualmente, informações sobre a cor da população, um dado complexo e que viveu uma história de entradas e saídas nas pesquisas realizadas pelo IBGE (Piza \& Rosemberg, 1999). Também a Pnad, a partir de 1995, incluiu no tópico sobre educação toda a faixa etária desde o nascimento, a fim de investigar crianças que frequentam creche, direito à educação reconhecido desde a Constituição Federal de 1988 (Rosemberg, 1997).

No Brasil, o movimento de mulheres, desde o início de sua mobilização, nos anos 70, foi outro segmento da sociedade que avaliou, criticou e propôs mudanças na forma de coletar dados, especialmente aqueles que se referiam à participação feminina na vida pública ou que evidenciavam menor adesão ao estereótipo tradicional. Por exemplo, as instruções para coletar dados sobre chefia de domicílio e participação da mulher no mercado de trabalho foram modificadas (Barroso, 1982; Bruschini \& Madeira, 1983).

Essas modificações acompanharam e contribuíram, certamente, para as transformações histórico-culturais que ocorreram, nas últimas décadas, nas relações de gênero, particularmente no que se refere à luta dos movimentos de mulheres pela maior participação feminina em espaços antes destinados exclusivamente aos homens: aqueles relacionados à esfera pública - política e econômica. Contudo, na sociedade contemporânea, a concepção e criação de filhos têm ainda sido uma atribuição exclusivamente feminina.

Como problematiza Figueroa-Perea (2004), a medicina e a demografia - disciplinas que têm investigado a reprodução e alimentado as políticas públicas que incidem sobre ela - questionam a reprodução como questão das mulheres. Entretanto, grande parte dos dados, informações, estudos e pesquisas, ao focar apenas as mulheres, parecem considerar que a reprodução é um assunto de mulheres, e esse questionável pressuposto tem validado indicadores com os quais são construídos os conhecimentos nesta área e vice-versa, ou seja, por sua vez, esses indicadores também validam o modelo cultural que os legitima (Berquó \& Cavenaghi, 2006).

Apesar das conquistas dos movimentos de mulheres e de toda uma variedade de importantes transformações no campo da sexualidade e da reprodução, ainda hoje se reproduz, nas relações de gênero, familiares e institucionais, uma delimitação clara de prescrições sociais e modelos. Ao homem provedor financeiro corresponde uma mulher naturalmente 
afetiva e maternal. Assim, a constatação de que, no Brasil, ainda predominam as máximas 'o filho é da mãe' e 'o pai abre a carteira' pode ser atestada pelos intentos que empreendemos para encontrar dados demográficos sobre o pai da criança brasileira (Lyra, 1997; Lyra \& Medrado, 2000).

Em pesquisa desenvolvida com o intuito inicial de identificar o número de pais adolescentes no Brasil (Lyra, 1997), analisamos questionários e formulários usados por diferentes instituições que coletam ou sistematizam informações demográficas, entre as quais: o IBGE, o Ministério da Saúde, a Sociedade Civil Bem-Estar Familiar no Brasil (Bemfam) e, em São Paulo, a Fundação Sistema Estadual de Análise de Dados (Fundação Seade, 1988, 1990, 1992, 1994, 1995).

Entretanto, se o objetivo inicial da nossa investigação era chegar a uma estimativa da paternidade na adolescência e sua variação percentual ao longo dos anos, a dificuldade de localizar dados sobre a paternidade, em todas as faixas etárias, levou-nos a uma mudança de foco. A ausência de informação tornou-se, assim, nosso objeto de interesse e estudo.

Naquele texto, enfatiza-se que o cuidado para com os filhos é uma atividade relacionada à reprodução da existência humana e, portanto, associada culturalmente às mulheres e ao feminino (Izquierdo, 1994). Seja no espaço da intimidade, seja no espaço público (Beatty, 1989), esta associação entre as mulheres e cuidado com a criança foi naturalizada.

Tal naturalização de um modelo social gerou uma série de discursos e práticas institucionalizadas, dando sustentação a determinados modelos, valores e prescrições que impossibilitam o registro de certas informações, contribuindo para a manutenção do princípio herdado do direito romano mater semper certa est, pater nunquam, ${ }^{11}$ que reforça e legitima a ausência paterna (Lyra \& Medrado, 2000; Fonseca, 2005; Perucchi, 2008).

Mais de dez anos depois da pesquisa realizada por Lyra (1997), observamos que a ausência de informações ainda é um dos problemas centrais para o desenvolvimento de um estudo sobre o lugar dos homens e das masculinidades nas políticas de direitos reprodutivos (Lyra, 2008). Encontramos esta mesma constatação em outros estudos que assinalam que discutir, à luz da perspectiva de gênero, a invisibilidade dos homens nos dados sociodemográficos e epidemiológicos, no campo das políticas públicas em direitos reprodutivos, tem raízes valorativas e ideológicas (Greene \& Biddlecom, 2000; Olavarría, 2003).

11 "A mãe é sempre certa, o pai, nunca". 
A ideia de que os homens geralmente não se interessam por questões relativas à sexualidade e à reprodução e de que o planejamento familiar e o cuidado dos filhos são atribuições e responsabilidades das mulheres estão embasadas em uma visão machista e sexista, que impede às mulheres e aos homens o pleno exercício de seus direitos sexuais e reprodutivos, em face das limitações impostas por padrões culturais inscritos em práticas preconceituosas. Com isso, não estamos negando os resultados de algumas pesquisas que evidenciam a resistência e a negação, por parte de alguns homens, em participar de experiências da vida reprodutiva (Alan Guttmacher Institute, 2003; Quadros, 1996, 2004).

Assim, se no campo da reprodução faltam informações, no campo da sexualidade esta matriz de gênero também se faz presente não apenas na invisibilidade de dados, mas também na maneira de interpretá-los. Dados sociodemográficos evidenciam, por exemplo, que, em 1980, a Aids situava-se na sétima posição entre as causas de mortalidade entre jovens brasileiros do sexo masculino, passando, em 1995, a ocupar a segunda posição (Brasil, 2005).

Nos últimos anos, tem-se observado uma tendência à 'feminização' da epidemia, que é expressa na gradativa diminuição da razão homem/ mulher no registro do número de casos notificados: de uma razão de 24:1 em 1985, passou-se para 6:1 em 1988, e tem-se mantido, desde 1997, a proporção de dois homens para cada mulher infectada (Brasil, 2005).

Contudo, mesmo registrando-se essa tendência à feminização da epidemia em âmbito mundial, e reconhecendo-se a grande importância e necessidade de ações voltadas para as mulheres, as estatísticas mostram ainda maior prevalência de casos entre os homens, nos mais variados recortes sociodemográficos - tais como faixa etária, domicílio - e na grande maioria das categorias de exposição ao vírus, principalmente por via sexual e sanguínea. Dados do Ministério da Saúde (Brasil, 2005) destacam que, no Brasil, 67,8\% da população infectada pelo HIV é de homens.

É interessante notar que, em 2000, o Programa Conjunto das Nações Unidas sobre HIV/Aids - Unaids (Joint United Nations Programme on HIV/Aids, 2000) lançou uma campanha mundial de prevenção à Aids, intitulada Aids: men make a difference. Este documento da campanha destaca:

Embora o comportamento dos homens esteja contribuindo de forma significativa para a propagação e o impacto do HIV, e os situe precisamente 
na primeira linha de risco, esse comportamento pode mudar. Conseguir a participação dos homens nos esforços contra a Aids representa o modo mais seguro de mudar o curso da epidemia. É improvável que se consiga motivar os homens para que escutem ou modifiquem suas atitudes apontando-os com o dedo ou culpando-os. Por meio da Campanha Mundial contra a Aids, a Unaids e seus associados em todo o mundo trabalharão cada vez mais com mulheres e homens, assim como com as ONGs, os governos e o sistema das Nações Unidas, para produzir um novo e muito importante enfoque voltado aos homens. (Joint United Nations Programme on HIV/Aids, 2000: 1 - Tradução dos autores)

Esse discurso da culpabilização dos homens e vitimização das mulheres aparece claramente expresso nos discursos institucionais sobre a epidemia da Aids, de forma semelhante à concepção 'satanizadora' dos homens apontada por Figueroa-Perea (2004). Além disso, a diversidade de atos sexuais e a relutância no uso de preservativos aparecem como algo generalizado e, ao mesmo tempo, como uma opção consciente.

Em síntese, consultando os bancos de dados do Departamento de Informática do Sistema Único de Saúde (Datasus) e as grandes pesquisas demográficas sobre morbimortalidade da população masculina (Laurenti et al., 1998; Laurenti, Mello-Jorge \& Gotlieb, 2005; Ripsa, 2007), bem como pesquisas sobre saúde reprodutiva (IBGE; 1996; Fundação Seade, 1988, 1990, 1992, 1994, 1995) e sobre comportamento sexual e infecção porDST/HIV/Aids (Bemfam, 1997), retomamos as perguntas que orientam nosso argumento neste texto: que masculinidades estão sendo forjadas pelos discursos de políticas públicas no campo da saúde, em nosso país? Que sujeito está sendo constituído por meio desses dispositivos de saber/ poder? E como uma política de atenção integral em saúde para os homens (no genérico) pode responder a demandas e necessidades específicas de 'homens de carne e osso', cuja experiência e valores estão inscritos em (e por) diferentes marcações de classe, cor/raça, idade, geração etc.?

\section{Por uma política de atenção integral aos homens na saúde}

Desde 2007, o Ministério da Saúde do Brasil assumiu o desafio de implementar uma política específica para atender às especificidades da população masculina no tocante à saúde. Trata-se de política ainda em processo de implementação, restrita a um documento síntese intitulado 
"Política Nacional de Atenção Integral à Saúde do Homem: princípios e diretrizes", ${ }^{12}$ produzido pelo Departamento de Ações Programáticas Estratégicas da Secretaria de Atenção à Saúde do Ministério da Saúde.

Para uma análise sobre o contexto de produção deste texto, é interessante fazer uma leitura comparativa tendo por base três documentos que orientam (ou pretendem orientar) políticas públicas no campo das relações de gênero e sexualidade em nosso país:

1) o Plano Nacional de Políticas para as Mulheres, produzido em 2007 e publicado em $2008(\mathrm{CNDH}, 2008)_{i}$

2) o Programa de Combate à Violência e à Discriminação contra GLTB (Gays, Lésbicas, Transgêneros e Bissexuais) e de Promoção da Cidadania de Homossexuais "Brasil sem Homofobia", publicado pelo Ministério da Saúde em 2004 (Brasil, 2004);

3) a referida proposição da Política Nacional de Atenção Integral à Saúde do Homem (Brasil, 2008), exposta no segundo semestre de 2008 à consulta pública pela área técnica de Saúde do Homem do Ministério da Saúde.

A construção desses três documentos teve trajetórias muito distintas, especialmente do ponto de vista da participação cidadã. O documento que orienta o Plano Nacional de Políticas para as Mulheres foi construído a partir do investimento coletivo que envolveu diretamente cerca de $200 \mathrm{mil}$ mulheres brasileiras em conferências municipais e estaduais, realizadas em todas as unidades da federação do país. Seu conteúdo expressa uma riqueza conceitual, epistemológica e política e, do nosso ponto de vista, vai além do corpo das mulheres, ao apontar como princípios: 1) igualdade e respeito à diversidade; 2 ) equidade; 3) autonomia das mulheres; 4) laicidade do Estado $_{i}$ 5) universalidade das políticas; 6) justiça social ${ }_{i}$ 7) transparência dos atos públicos e 8) participação e controle social.

Da mesma forma, o Programa de Combate à Violência e à Discriminação contra GLBT e de Promoção da Cidadania de Homossexuais "Brasil sem Homofobia" foi construído a partir de intenso debate com os movimentos sociais organizados e avança para além da catalogação de identidades sexuais - ou "sopa de letrinhas" (Facchini, 2005), apontando como princípio a inclusão da perspectiva da não discriminação por orientação sexual na formulação e implementação de políticas públicas.

12 Disponível em: <http://dtr2001.saude.gov.br/sas/PORTARIAS/Port2008/PT-09-CONS.pdf. Acesso em: mar. 2011. 
Reafirma-se que a defesa, a garantia e a promoção dos direitos humanos incluem o combate a todas as formas de discriminação e de violência e que, portanto, o combate à homofobia e a promoção dos direitos humanos de homossexuais é um compromisso do Estado e de toda a sociedade brasileira.

O texto exposto à consulta pública pelo Ministério da Saúde para uma política de atenção integral aos homens na saúde ainda carece de consistência e coerência conceitual e política. Sua construção teve por base, inicialmente, encontros com especialistas e representantes de entidades da área da saúde, reservando aos cidadãos espaço apenas para consulta pública (feita via Internet). Além disso, este processo esteve à margem das conferências de saúde.

Em termos de conteúdo, o documento baseia-se em um panorama descritivo parcial sobre a saúde, ou melhor, sobre adoecimento e morte dos homens, com base em estatísticas, e apresenta leitura limitada sobre determinantes sociais em saúde, marcados por gênero, classe, raça e idade, dando pouca visibilidade às produções importantes no campo da antropologia e psicologia social, alicerçadas em pesquisas qualitativas que exploram valores e normas culturais (Abrasco, 2005).

Ainda que as seções "Princípios" e "Diretrizes" apresentem uma leitura mais complexa do fenômeno, o objetivo geral da política é descrito de forma limitada a promover a melhoria das condições de saúde da população masculina do Brasil, contribuindo, de modo efetivo, para a redução da morbidade e mortalidade dessa população, por meio do enfrentamento "racional" (sic) dos "fatores de risco" (sic.) e mediante a facilitação ao acesso aos serviços e ações de assistência integral à saúde.

Ratificamos o depoimento de Adson França, ${ }^{13}$ diretor do Departamento de Ações Programáticas Estratégicas (Dape), da Secretaria de Atenção à Saúde, quando afirma que "terá que haver uma mudança social na escola, no trabalho, na família, entre outros espaços sociais" (...). "É uma questão cultural, e mudar a cultura é um grande desafio".

Assim, para contribuir para este debate, apresentamos a seguir um conjunto de princípios e diretrizes que consideramos fundamentais para a formulação de uma política de atenção integral aos homens na saúde. ${ }^{14}$

13 Radis-Comunicação em Saúde, 74, out. 2008.

14 Essas diretrizes foram originalmente publicadas pela Rede de Homens pela Equidade de Gênero, em formato de folheto. Para maiores informações acessar: <www.lacobranco.org.br>. 
1) Uma política de saúde para os homens não deve gerar ameaças aos direitos das mulheres.

As ações em saúde pública dirigidas à população masculina devem ser vistas como um avanço das políticas feministas e de gênero, na medida em que trazem benefícios para a vida dos homens, mas também para a vida das mulheres. Não deve, portanto, competir por investimentos ou recursos destinados à saúde das mulheres, nem criar estruturas isoladas. Deve atuar conjuntamente com as demais políticas de saúde, maximizando esforços e minimizando custos.

2) Cuidar da saúde não é apenas tratar das doenças.

É muito importante reconhecer que as necessidades dos homens em relação à sua saúde não se limitam aos males da próstata ou outras enfermidades. É necessário também levar em consideração os aspectos psicossociais e culturais, não restringindo as ações às práticas assistenciais ou de caráter emergencial. Assim, a atenção à saúde deve incluir medidas preventivas e implementar ações educativas de promoção à saúde, fortalecendo a atenção básica.

3) A atenção à saúde masculina deve ser integral.

Para que seja efetiva, a atenção à saúde dos homens deve ser integral, ou seja, não se limitar aos aspectos biológicos e envolver: a) equipes multidisciplinares nas quais os profissionais dialoguem entre si $_{i}$ b) ações em saúde que contemplem o aspecto da assistência, prevenção e promoção; c) prática coordenada e continuada de atenção, por meio da interação com outras unidades de saúde e com outros setores (educação, esporte, trabalho, cultura, lazer etc.).

4) Informação é a base de qualquer política pública.

Conhecemos pouco sobre a saúde e o adoecimento dos homens. Muitas vezes, os profissionais acabam trabalhando com dados parciais, restritos à sua própria experiência. Portanto, é preciso qualificar melhor os sistemas de informação, gerando e divulgando sistematicamente dados sobre: a) as principais necessidades dos homens em termos de saúde; b) as principais causas de adoecimento e de morte; c) acessibilidade aos serviços etc. Esses dados devem fazer recortes especiais por sub-regiões, para que as propostas sejam ainda mais adequadas. 
5) Os homens não são iguais.

A política de saúde deve respeitar a diversidade e as propostas precisam estar adequadas a esta diversidade, respeitando diferenças por idade, credo religioso, condição socioeconômica, cor/raça, orientação sexual e necessidades especiais.

6) Homens jovens, negros e pobres merecem atenção especial.

Muitas vezes achamos que, por serem jovens, os rapazes não precisam de atenção em saúde. Os homens jovens, negros e pobres, residentes em bairros de periferia, constituem a população mais atingida pela violência e outros fatores que afetam diretamente sua saúde. Precisamos criar estratégias especiais para atrair esses homens jovens para os serviços de saúde, ressignificando valores e oferecendo atenção de qualidade, adequada às suas necessidades, de modo a garantir os princípios da equidade e universalidade do SUS.

7) É necessário também incluir os homens idosos

Problemas de saúde decorrentes do envelhecimento são comuns, porém é possível envelhecer de modo saudável. Infelizmente, os homens idosos são uma população com maior resistência em procurar auxílio. Os serviços devem se ocupar das necessidades específicas que merecem atenção especial, particularmente no que se refere ao autocuidado e aos agravos decorrentes de problemas do aparelho circulatório e genital.

8) Os serviços de saúde devem ser amigáveis.

Muitos homens pensam que cuidar da saúde é 'coisa de mulher' e que os serviços de saúde devem ser procurados apenas quando a doença já está em estágio avançado. A atenção à saúde precisa promover o acolhimento das necessidades dos homens em geral e atrair esta população, ou seja, não apenas responder a demandas.

9) É preciso ir aonde os homens estão.

Mais de $95 \%$ da população carcerária no Brasil é composta por homens. O contingente das Forças Armadas e de albergues públicos também é composto prioritariamente por homens. Além disso, homens que residem em contextos rurais, indígenas e quilombolas sofrem ainda mais com a dificuldade de acesso aos serviços públicos de saúde. Para atuar na promoção de saúde junto à população masculina, é fundamental desenvolver estratégias voltadas também para estes contextos e espaços coletivos. 
10) A emergência é também espaço de prevenção.

O setor de emergências recebe uma população expressivamente maior de homens, em decorrência de fraturas, traumas e crises agudas. Este setor se caracteriza por precárias condições de atendimento, falta de recursos materiais e humanos, bem como pouca sensibilidade para o atendimento integral aos usuários. É necessário investir estruturalmente nesses setores, favorecendo uma 'emergência humanizada' que possa estimular, nos homens, uma revisão de seus valores e práticas, promovendo prevenção secundária.

11) Sexualidade e reprodução também são questões de saúde para os homens.

A participação dos homens em ações voltadas à sexualidade e saúde reprodutiva traz benefícios para a saúde dos homens e, consequentemente, das mulheres e das crianças. É importante produzir ações que promovam o autocuidado e o cuidado com os outros.

12) Paternidade é também um direito.

É preciso ampliar a reflexão sobre o cuidado infantil. A paternidade (seja biológica ou por adoção) é uma prática que pode gerar benefícios subjetivos e materiais para a vida e a saúde dos homens e das próprias crianças. A paternidade não é apenas uma responsabilidade ou obrigação, é também um direito e pode gerar muito prazer. É necessário entender que pai não é visita e que muitos são aqueles que têm interesse em participar do desenvolvimento dos seus filhos. Os serviços precisam se adequar a esta realidade, promovendo acolhimento e, em alguns casos, adaptando sua rotina e estrutura para garantir o exercício da paternidade, especialmente no pré-natal, parto e pósparto, bem como na pediatria.

13) Violência de gênero é também questão de saúde pública.

Nossa sociedade se fundamenta em modelos culturais que definem o que é masculino e feminino. Esses padrões de gênero reproduzem a ideia de que os homens são naturalmente violentos. Portanto, a violência dos homens contra as mulheres (sejam crianças, adolescentes ou adultas) ou contra outros homens (sejam homossexuais ou heterossexuais) são violências baseadas em gênero, construídas a partir de processos culturais, institucionais e psicossociais. Para mudar os quadros de violências baseadas em gênero, é fundamental implementar 
ações mais eficazes de segurança pública, aliadas a ações em saúde de caráter preventivo dirigidas aos homens e também de atendimento a autores de violência.

14) A redução de danos deve ser um princípio básico nas ações em saúde.

Os homens compõem a parcela da população que mais consome álcool e outras drogas. Para atuar junto aos homens que usam drogas, os serviços de saúde devem rejeitar medidas punitivas, restritivas ou culpabilizantes. É necessário implantar estratégias para reduzir os danos que o uso de drogas possa causar a essas pessoas, garantindo-se os princípios da cidadania e dos direitos humanos, à luz das discussões sobre gênero e masculinidades.

15) Os gestores e os profissionais de saúde precisam rever práticas, conceitos e valores.

Ações educativas devem ser oferecidas aos gestores e profissionais de saúde para que possam compreender a importância e a necessidade de ações dirigidas aos homens, bem como definir, coletivamente, prioridades e estratégias de ação a serem implementadas em seu serviço. Esse processo educativo deve promover a crítica a posturas machistas que, muitas vezes, não permitem perceber que os homens também possuem necessidades específicas em saúde.

16) Saúde é uma questão de cidadania.

Promover e garantir a participação popular envolvendo homens e mulheres, jovens e adultos em qualquer processo de formulação e monitoramento de políticas públicas em saúde é um exercício de cidadania e a garantia do controle social das políticas.

Essas proposições evidenciam uma variedade de temas e objetos de estudo que indicam potenciais pesquisas e campos de debate não plenamente explorados neste texto. Indicam também a necessidade de um posicionamento ético-político claro na interface com as conquistas feministas.

É importante reconhecer que o feminismo foi responsável por uma revolução em nossa sociedade, tanto no campo da ciência como na vida cotidiana das pessoas. Ao discutir e buscar transformar a condição de subordinação das mulheres, fez um deslocamento crítico necessário em relação ao lugar de dominação dos homens, apresentando desafios e 
avanços e apontando caminhos de transformação não plenamente implementados.

Destacamos ainda a necessidade e a importância de um posicionamento analítico e crítico a respeito do 'discurso sobre/dos homens', tendo em vista o avanço do conhecimento neste campo formulado pelas feministas - e alguns homens, feministas ou não! (Lyra, 2009). O que temos percebido nos trabalhos sobre homens e masculinidades é uma tendência a realizar investigações com caráter meramente descritivo e a desconsiderar que a trajetória histórica das reflexões neste campo vem do movimento de mulheres e feminista e também do movimento gay e lésbico.

Como afirmamos anteriormente, gênero, como categoria de análise, é uma ferramenta dos estudos científicos/acadêmicos para questionar relações de poder. Esta contribuição epistemológica, teórica e metodológica tem uma história própria e uma autoria que não é possível desconsiderar. É necessário reconhecer e nomear esta autoria, pois muitas vezes gênero é reconhecido como mais um conceito das ciências humanas, quando foi inicialmente formulado pelo movimento feminista, já com caráter teórico e político.

Quando desenvolvemos uma revisão da literatura ou participamos de algumas discussões em reuniões de trabalho, seminários e diálogos com grupos de homens, a sensação é que os estudos e as ações públicas sobre/ com os homens estão (re)fazendo todo o percurso que as mulheres já fizeram, ou seja, parando agora para 'escutar' e descrever o que os homens têm a dizer, iniciando do zero, sem problematizar estes próprios discursos.

Os sentidos sobre homens e masculinidades também são polissêmicos, e não dicotômicos, como os autores apresentam na literatura científica sobre o tema. Em nossa experiência de investigação/intervenção social, colocamos estes aspectos em suspeição, e não como um fato dado.

Temos aprendido a separar, empírica e analiticamente, as questões de gênero (masculinidades/feminilidades), sexualidade (a diversidade dos caminhos do sexo, afeto e amor), conjugalidade (a condição de ser marido e esposa) e parentalidade (a condição de ser pai e mãe). É óbvio que há um fio que pode (ou não!) conectar estes elementos constitutivos das subjetividades das pessoas, mas de antemão olhamos criticamente os discursos sobre o fenômeno da masculinidade, para tentar evitar cair na armadilha da fixidez da heteronormatividade, do sexismo, do racismo, da homofobia e do machismo que permeiam a nossa sociedade. 
Estas considerações fundamentam a crença de que podemos construir outros 'roteiros' mais críticos e ousados sobre os homens e as masculinidades, quando apostamos no caráter subversivo que a perspectiva feminista pode nos oferecer ao defender que é possível a utopia da transformação social.

\section{Referências}

ALAN GUTTMACHER INSTITUTE. Their Own Right: addressing the sexual and reproductive health needs of men worldwide. New York: Alan Guttmacher Institute, 2003.

ANDRADE, L. F. \& ROSEMBERG, F. Ruthless rethoric: child and youth prostitution in the Brasilian media. In: URBAN CHILDHOOD: AN INTERNATIONAL, INTERDISCIPLINARY CONFERENCE, 9-12 jun. 1997, Trondheim, Norway.

AQUINO, E. M. Gênero e saúde: perfil e tendências da produção científica no Brasil. Revista de Saúde Pública, 40(n. especial): 121-132, 2006.

ARILHA, M. Masculinidades e Gênero: discursos sobre responsabilidade na reprodução, 1999. Dissertação de Mestrado em Psicologia Social, São Paulo: Pontifícia Universidade Católica de São Paulo.

ARILHA, M. O Masculino em Conferências e Programas das Nações Unidas: para uma crítica do discurso de gênero, 2005. Tese de Doutorado em Saúde Pública, São Paulo: Faculdade de Saúde Pública, Universidade de São Paulo.

ARILHA, M.; UNBEHAUM, S. \& MEDRADO, B. (Orgs.). Homens e Masculinidades: outras palavras. São Paulo: Ecos, Editora 34, 1998.

ARROW. Investigating the role of men in women's reproductive \& sexual health. In: IRRRAG MEETING, 25-29 mar. 2002, Kuala Lumpur. (Mimeo.)

ASSOCIAÇÃO BRASILEIRA DE SAÚDE COLETIVA (ABRASCO). Saúde do homem: alerta e relevância. Ciência \& Saúde Coletiva, 10(1): 47-57, 2005.

BARBIERI, T. Sobre la categoría género: una introducción teórico-metodológica. In: RODRÍGUES, R. (Ed.). Fin de Siglo: género y cambio civilizatorio. Santiago: Isis International, 1992.

BARBOSA, M. I. Racismo e Saúde, 1998. Tese de Doutorado em Saúde Pública, São Paulo: Faculdade de Saúde Pública, Universidade de São Paulo.

BARROSO, C. Mulher, Sociedade e Estado no Brasil. São Paulo: Unicef, Brasiliense, 1982 .

BATISTA, L. E. Masculinidade, raça/cor e saúde. Ciência \& Saúde Coletiva, 10(1): 71 $80,2005$. 
BEATTY, B. A vocation from on high: kindergartning as an occupation for American women. In: WARREN, D. (Ed.). American Teachers: histories of a profession at work. New York: Macmillan, 1989.

BERQUÓ, E. \& CAVENAGHI, S. Fecundidade em declínio: breve nota sobre a redução no número médio de filhos por mulher no Brasil. Revista Novos Estudos, 74: 11 $15,2006$.

BRASIL. Ministério da Saúde. Brasil sem Homofobia: programa de combate à violência e à discriminação contra GLTB e promoção da cidadania homossexual. Brasília: Ministério da Saúde, 2004.

BRASIL. Ministério da Saúde. Secretaria de Vigilância em Saúde. Evolução da Mortalidade por Violência no Brasil e Regiões. Brasília: Ministério da Saúde, 2006.

BRASIL. Ministério da Saúde. Política Nacional de Atenção Integral à Saúde do Homem: princípios e diretrizes. Brasília: Departamento de Ações Programáticas Estratégicas da Secretaria de Atenção à Saúde, Ministério da Saúde, 2008. Disponível em: <http://dtr2001.saude.gov.br/sas/PORTARIAS/ Port2008/PT-09CONS.pdf >. Acesso em: 2 mar. 2011.

BRASIL. Secretaria de Vigilância em Saúde. Programa Nacional de DST e Aids. Boletim Epidemiológico - Aids e DST, 1(2): 42, 2005.

BRUSCHINI, C. \& MADEIRA, F. A família, a estrutura social e as formas de participação na produção social. Cadernos Ceru, 18: 147-186, 1983.

CONNELL, R. W.; HEARN, J. \& KIMMEL, M. Introduction. In: KIMMEL, M.; HEARN, J. \& CONNELL, R. W. (Eds.). Handbook of Studies on Men and Masculinities. California: Sage, 2005.

CONSELHO NACIONAL DOS DIREITOS DA MULHER (CNDH). Secretaria Especial de Políticas para as Mulheres da Presidência da República - SPM. II Plano Nacional de Políticas para as Mulheres. Brasília: CNDH, 2008.

CORRÊA, S. Gênero e políticas públicas no Brasil. In: SEMINÁRIO 'GÊNERO E POLÍTICAS PÚBLICAS', CONSELHO NACIONAL DOS DIREITOS DA MULHER, 7 mar., Brasília, 2002.

ECOS. Sexualidade e Saúde Reprodutiva. São Paulo: Instituto Promundo, Instituto Papai, Salud y Género, 2001. (Série Trabalhando com Homens Jovens)

FACCHINI, R. Sopa de Letrinhas? Movimento homossexual e produção de identidades coletivas nos anos 90. Rio de Janeiro: Garamond, 2005. (Seção Garamond Universitária)

FIGUEROA-PEREA, J. G. Algunos elementos para interpretar la presencia de los varones en los procesos de salud reproductiva. Cadernos de Saúde Pública, 14 (supl. 1): 87-96, 1998. 
FIGUEROA-PEREA, J. G. La representación social de los varones en estudios sobre masculinidad y reproducción: 'un muestrario de reflexiones. In: SEMINÁRIO INTERNACIONAL/SEMINÁRIO NORTE-NORDESTE SOBRE 'HOMENS, SEXUALIDADE E REPRODUCÃO: TEMPOS, PRÁTICAS E VOZES', 1/2, 17 20 jun. 2003, Recife. (Mimeo.)

FIGUEROA-PEREA, J. G. La representación social de los varones en estudios sobre masculinidades y reproducción: un muestrario de reflexiones. In: MEDRADO, B. et al. (Orgs.). Homens: tempos, práticas e vozes. Recife: Instituto Papai, Fages, Nepo, Unicamp, Pegapacapá, 2004.

FONSECA, C. L. W. Paternidade brasileira na era do DNA: a certeza que pariu a dúvida. Quaderns-e, 4: 27-51., 2005.

FUndAÇÃO SEADE. O Jovem na Grande São Paulo. São Paulo: Seade, 1988. (Coleção Realidade Paulista, 2).

FUndAÇÃO SEADE. Pesquisa de Condições de Vida - PCV: manual do entrevistador. São Paulo: Seade, 1990.

FUNDAÇÃO SEADE. Coleção Pesquisa de Condições de Vida na Região Metropolitana de São Paulo - PCV 1992 - análises especiais: crianças e adolescentes. São Paulo: SEADE, 1992.

FUndAÇÃO SEADE. Pesquisa de Condições de Vida - PCV: manual do entrevistador. São Paulo: Seade, 1994.

FUNDAÇÃO SEADE. Nascer Aqui: análise de uma nova fonte de dados sobre nascimentos. São Paulo: Seade, 1995. (Informe Demográfico, 29).

GOMES, R. Sexualidade masculina e saúde do homem: proposta para uma discussão. Ciência \& Saúde Coletiva, 8(3): 825-829, 2003.

GOMES, R. Entrevista. Radis - Comunicação em Saúde, 74, out. 2008.

GREENE, M. \& BIDDLECOM, A. Absent and problematic men: demographic accounts of male reproductive roles. Population and Development Review, 26(1): $81-115,2000$.

HAMAWI, R. Introdução: que querem os homens? In: NOLASCO, S. (Org.). A Desconstrução do Masculino. Rio de Janeiro: Rocco, 1995.

INSTITUTO BRASILEIRO DE GEOGRAFIA E ESTATÍSTICA (IBGE). Pesquisa Nacional por Amostra de Domicílios - Pnad. Brasília: IBGE, 1996.

IZQUIERDO, M. J. Uso y abuso del concepto de gênero. In: VILANOVA, M. (Org.). Pensar las Diferencias. Barcelona: Promociones y Publicaciones Universitarias, 1994.

JABLONSKI, B. A difícil extinção do boçalossauro. In: NOLASCO, S. (Org.). A Desconstrução do Masculino. Rio de Janeiro: Rocco, 1995. 
JOINT UNITED NATIONS PROGRAMME ON HIV/AIDS (UNAIDS). Men and Aids: a gendered approach - 2000 World Aids. Genève: Unaids, 2000.

KINGDON, J. W. Agendas, Alternatives, and Public Policies. Boston: Little, Brown and Company, 1984.

LAURENTI, R.; MELLO JORGE, M. H. P. \& GOTLIEB, S. L. D. Perfil epidemiológico da morbi-mortalidade masculina. Ciência \& Saúde Coletiva, 10(1): 35-46, 2005.

LAURENTI, R. et al. D. Perfil Epidemiológico da Saúde Masculina na Região das Américas: uma contribuição para o enfoque de gênero. São Paulo: Centro Colaborador da OMS para a Classificação de Doenças em Português, 1998.

LONGHI, M. R. Viajando em seu Cenário: reconhecimento e consideração a partir de trajetórias de rapazes de grupos populares do Recife, 2008. Tese de Doutorado em Antropologia, Recife: Universidade Federal de Pernambuco.

LYRA, J. Paternidade Adolescente: uma proposta de intervenção, 1997. Dissertação de Mestrado em Psicologia Social, São Paulo: Pontifícia Universidade Católica de São Paulo.

LYRA, J. Homens, Feminismo e Direitos Reprodutivos no Brasil: uma análise de gênero no campo das políticas públicas (2003-2006), 2008. Tese de Doutorado em Saúde Pública, Recife: Departamento de Saúde Coletiva, Centro de Pesquisas Aggeu Magalhães, Fundação Oswaldo Cruz.

LYRA, J. Gênero, saúde e análise de políticas: caminhos e (des)caminhos. Ciência \& Saúde Coletiva, 14(4): 1.010-1.012, 2009.

LYRA, J. \& MEDRADO, B. Gênero e paternidade nas pesquisas demográficas: o viés científico. Revista Estudos Feministas, 8(1): 145-158, 2000.

MEDRADO, B. A Masculinidade na Propaganda Televisiva Brasileira, 1997. Dissertação de Mestrado em Psicologia Social, São Paulo: Pontifícia Universidade Católica de São Paulo.

MEDRADO, B. \& LYRA, J. Por uma matriz feminista de gênero para os estudos sobre homens e masculinidades. Revista Estudos Feministas, 16: 20-35, 2008

NOLASCO, S. O Mito da Masculinidade. Rio de Janeiro: Rocco, 1993.

NOLASCO, S. (Org.). A Desconstrução do Masculino. Rio de Janeiro: Rocco, 1995.

OLAVARRÍA, J. Derechos sexuales y reproductivos y los hombres. In: DIÁLOGO NACIONAL: PROMOCIÓN DE LA SALUD SEXUAL Y REPRODUCTIVA EN LA REFORMA DEL SECTOR SALUD, 21-22 ago. 2003, Santiago de Chile. Anais... Santiago de Chile: Inap, Universidad de Chile, 2003. Disponível em: <www.flacso.cl/flacso/biblos.php?code=619>. Acesso em: 2 mar. 2011.

OLIVEIRA, M. C.; BILAC, E. D. \& MUSZKAT, M. Homens e anticoncepção: um estudo sobre duas gerações masculinas das camadas médias paulistas. In: ENCONTRO NACIONAL DE ESTUDOS POPULACIONAIS, XII, 2000, Caxambu. Anais... Caxambu: Abep, 2000. (Mimeo.). 
OliVEIRA, P. P. de. A Construção Social da Masculinidade. Belo Horizonte, Rio de Janeiro: Editora UFMG, Iuperj, 2004.

PERUCCHI, J. Mater Semper Certa Est Pater Nunquan: o discurso jurídico como dispositivo de produção de paternidades, 2008. Tese de Doutorado em Psicologia, Florianópolis: Universidade Federal de Santa Catarina.

PIZA, E. \& ROSEMBERG, F. Color in the Brazilian census. In: REICHMANN, R. (Ed.). Race in Contemporary Brazil: from indifference to inequality. University Park: The Pennsylvania State University Press, 1999.

POTTER, J. \& WETHERELL, M. Analyzing discourse. In: BRYMAN, A. \& BURGESS, R. (Eds.). Analyzing Qualitative Data. London: Routledge, 1991.

QUADros, M. T. Construindo uma Nova Paternidade? As representações masculinas de pais de alunos de uma escola alternativa do Recife, 1996. Dissertação de Mestrado em Antropologia, Recife: Universidade Federal de Pernambuco.

QUADROS, M. T. Homens e a Contracepção: práticas, ideias e valores masculinos na periferia do Recife, 2004. Tese de Doutorado em Sociologia, Recife: Universidade Federal de Pernambuco.

REDE INTERAGENCIAL DE INFORMAÇÕES PARA A SAÚDE (RIPSA). IDB 2006. Brasil: indicadores e dados básicos. Brasília: Ministério da Saúde, 2007. Disponível em: <http://tabnet.datasus.gov.br/cgi/idb2006/matriz.htm>. Acesso em: 20 out. 2007.

ROSEMBERG, F. Educación infantil, género y raza. In: INTERNATIONAL CONGRESS OF LATIN AMERICAN STUDIES ASSOCIATION, 20, 1997, Guadalajara. (Mimeo.)

SCOTT, J. W. Gênero: uma categoria útil para análise histórica. Educação \& Realidade, 20(2): 71-99, 1995.

SOCIEDADE CIVIL BEM-ESTAR FAMILIAR NO BRASIL (BEMFAM). DST/Aids e a Pesquisa Nacional sobre Demografia e Saúde: uma análise do nível de conhecimento e comportamentos de vulnerabilização. Rio de Janeiro: Bemfam, 1997.

SPINK, M. J. \& MENEGON, V. M. A pesquisa como prática discursiva: superando os horrores metodológicos. In: SPINK, M. J. (Org.). Práticas Discursivas e Produção de Sentidos no Cotidiano: aproximações teóricas e metodológicas. São Paulo: Cortez, 1999.

TONELI-SIQUEIRA, M. J. F. Saúde e Direitos Reprodutivos: o que os homens têm a ver com isso?. Revista Estudos Feministas, 8(1): 159-168, 2000.

VALE-DE-ALMEIDA, M. Senhores de Si: uma interpretação antropológica da masculinidade. Lisboa: Fim de Século, 1995. 
VALE-DE-ALMEIDA, M. Gênero, masculinidade e poder: revendo um caso do sul de Portugal. Anuário Antropológico (Brasil), 95: 161-190, 1996.

VIANA, A. L. Abordagens metodológicas em políticas públicas. Revista de Administração Pública, 30(2): 5-42, 1996. 


\section{Vulnerabilidade Masculina, Curso de Vida e Moradia Urbana: um dilema para homens adultos de bairros populares}

Parry Scott

Como explorar as conexões entre o espaço urbano e o espaço doméstico a partir das vivências das pessoas de bairros populares? Quais as implicações para a saúde do homem?

Com base em análise de dados censitários da cidade do Recife e em experiências etnográficas em diferentes comunidades da cidade, argumenta-se que homens entre 40 e 45 anos que residem em bairros populares experimentam um aumento da vulnerabilidade social e individual. Essa vulnerabilidade é mascarada por uma prática de negação decorrente de eles mesmos não admitirem a perda do controle sobre o domínio doméstico e, especialmente, sobre as mulheres.

Defende-se, aqui, que a combinação de exogamia feminina e trabalho doméstico para fora produz efeitos cumulativos que paulatinamente impedem os homens de exercerem as suas práticas prediletas de manterem as suas casas sob controle, desejando tornarem-se patriarcas de pequenos patrimônios.

Três fenômenos ocorrem: 1) a circulação de mulheres para fora dos bairros populares permite acesso a recursos materiais e relacionais; 2 ) essas mulheres formam redes femininas de informações, recursos e serviços que as colocam como controladoras de circuitos que valorizam mais as mulheres do que os homens dos bairros populares, o que acentua a

1 A elaboração de um trabalho para o seminário internacional Os Jovens e a Cidade no Recife em março de 2002, ampliado, revisado e publicado em Scott e Franch (2004) e o trabalho de campo para a pesquisa Estilos Reprodutivos e Organizações Reprodutivos, com apoio da Fundação Ford, serviram como base inicial da reflexão aqui apresentada. 
vulnerabilidade individual e social ${ }^{2}$ e redunda em vulnerabilidade programática, sobretudo na área de saúde.

Para apoiar esse argumento, é preciso esboçar algumas indagações sobre a mensurabilidade dos dados, discutindo as potencialidades das articulações entre duas diferentes fontes de dados (censitários e etnográficos) e buscando as repercussões potenciais dessas articulações para compreender a inserção de homens de bairros populares da cidade em redes de serviços de saúde e das vulnerabilidades às quais eles estão expostos.

Em diversas experiências de pesquisa em áreas urbanas, a ideia de ciclos domésticos, bastante utilizada em estudos de sociedades camponesas (Chayanov, 1966) e de sociedades tradicionais (Meyer Fortes, 1958), tem servido para estabelecer diferenças sobre as vivências na cidade. A ideia de ciclo doméstico, que pressupõe alguma regularidade na formação das famílias ao longo da vida das pessoas que as compõem, tem gerado discussão, produzindo polêmica sobre a sua aplicabilidade a realidades urbanas contemporâneas.

Alguns autores, diante disso, preferindo lidar com ideias de curso de vida ou outras formas aproximativas da noção, buscam conferir maior destaque à dimensão individual neste processo social coletivo.

Ainda neste debate, há um conjunto de autores que eloquentemente defendem a procura da variabilidade dentro de estruturas que aparentam ser limitantes. Internacionalmente, Jennifer Johnson-Hanks (2002) trabalha com a ideia de vital conjunctures, que realça mais a subjetividade das experiências vividas e menos a própria sequência de categorias fundamentadas em faixas etárias.

Outra autora que revisa a literatura sobre ciclos e cursos de vida, Elaine Muller (2008), focaliza as oscilações do que ela chama de "transições" nas vidas de pessoas. Segundo ela, as pessoas identificam de forma bastante solta as transições, ou fases, que estão vivendo, como mais associadas à idade adulta ou à juventude, o que torna ambas as categorias altamente

2 Segundo Hermes Junior (2010): "podemos definir a vulnerabilidade individual como o conhecimento (ou não) acerca do agravo e a existência de comportamentos que oportunizam a ocorrência da doença. No plano institucional ou programático, a vulnerabilidade está associada à existência de políticas e ações organizadas para enfrentar o problema. E, finalmente, a vulnerabilidade social avalia a dimensão social do adoecimento, utilizando-se indicadores capazes de revelar o perfil da população no que se refere ao acesso à informação, gastos com serviços sociais e de saúde, acesso aos serviços de saúde, dentre outros. A vulnerabilidade social pode ser entendida, portanto, como um espelho das condições de bem-estar social". 
flexíveis. Mônica Franch (2008), ao remeter a atenção para a vivência de tempo social, também valoriza as adesões diferentes que pessoas, frequentemente em condições sociais semelhantes, fazem à ideia de 'tempo' para ordenar a compreensão do andamento do curso de vida. Dessa forma, cria-se uma multiplicidade de trajetos, cursos ou ciclos possíveis, conferindo mais agência aos sujeitos pesquisados. Nas pesquisas realizadas em Recife, Dalsgaard, Franch e Scott (2008) realçam o quanto a vida vivida se afasta de padrões e modelos idealizados.

Estes estudos são alertas fundamentais para não se aderir plenamente à ideia quase mecânica de haver um ciclo ou curso estruturante e repetitivo. Entretanto, considerando-se as regularidades que aparecem em dados quantitativos, não convém anular o poder interpretativo da ideia de curso de vida em nome de um excesso de respeito à subjetividade de indivíduos que, pela sua idade ou experiência de vida, potencialmente se inserem em fases semelhantes.

Assim, examinam-se aqui dados do Censo 2000, mas sempre recorrendo a algumas observações de trabalhos etnográficos. A partir de um olhar panorâmico usando dados censitários sobre espaços da cidade do Recife, dividem-se os bairros ou comunidades pobres e bairros ou comunidades ricas. Os dados etnográficos se atêm ao fluxo de pessoas e recursos entre estes dois espaços (bairros ou comunidades pobres e ricas), buscando entender como homens e mulheres vivem o cotidiano e estabelecem relações de gênero associadas à vivência de vulnerabilidades individuais, sociais e programáticas, com foco nas questões de saúde masculina.

A ideia de curso de vida contém uma flexibilidade suficiente que ajuda a interpretar a experiência diferenciada de gerações e de gênero no espaço urbano, sem desprezar por inteiro a ideia de ciclos. Assim, podemse observar algumas diferenças na construção de redes de sociabilidade de jovens, adultos e idosos, de ambos os sexos, e as suas consequências para a vida cotidiana e a saúde dos homens, a partir de dados sobre a proporção de homens e mulheres que residem em domicílios em espaços urbanos diferenciados por renda e tipo de residência.

Entende-se que dados quantitativos, pela própria natureza, carecem de algumas informações relacionadas a conexões lógicas necessárias para compreender mais plenamente as relações entre os processos em pauta. Como é que homens e mulheres de idades e experiências de cursos de vida diferentes circulam entre bairros e produzem e circulam recursos 
para constituir patrimônios que contribuem para relações de gênero e vulnerabilidades diferentes? Dados etnográficos acumulados em uma multiplicidade de estudos no Recife e em outras cidades do Brasil permitem elaborar interpretações plausíveis acerca do problema.

Diferentes formas de sociabilidade geracionais e de gênero sugerem que haja uma relação com a construção de patrimônios domésticos ao longo do curso da vida. Scott (1990) enfatiza que 'ciclos domésticos' vividos são estruturalmente diferenciados para homens e para mulheres. Esta diferença é fundamental para entender o que designamos aqui vulnerabilização masculina e controle da circulação de mulheres como fazendo parte da construção de patrimônios com legitimidade moral. Em alguns aspectos, a ideia é antiga, mas a roupagem talvez nem tanto. A combinação de quebras no ciclo doméstico e a resistência a elas sinalizam momentos-chave para o rearranjo de relações entre homens e mulheres que estabelecem os próprios cursos de vida dentro do campo de possibilidades que se apresentam.

A flexibilidade histórica de arranjos conjugais e residenciais, inclusive diante de um incremento atual notável de separações e divórcios, promove descontinuidades na vivência de ciclos domésticos para homens e mulheres. Para os homens, que costumam não ficar com os filhos em uma separação, é mais fácil que esta descontinuidade os leve a iniciar outro ciclo com uma nova parceira. Diferentemente, as mulheres encontram formas de significar a continuidade da sua aliança no espaço doméstico entre mãe, filhos e outras parentas solidárias, secundarizando, ainda sem desmerecer o valor, a relação afetivo-sexual de status doméstico com outro parceiro.

Não é somente a vivência com rumos distintos nos cursos de vida que merece atenção para compreender as vivências diferenciadas entre homens e mulheres. A relação entre bairros e movimentos populacionais de gênero, geração e recursos materiais e não materiais também são importantes para entender este fenômeno.

As vulnerabildades vividas variam ao longo dos cursos de vida, o que reflete instâncias diferentes da vulnerabilidade social costumeiramente experimentadas pelas camadas populares. A vulnerabilidade entre integrantes de outras camadas, com mais acesso a recursos, não segue o mesmo padrão nos seus cursos da vida. Alguns aspectos da vulnerabilidade social de camadas populares se evidenciam através de uma vulnerabilidade programática, ou seja, através da fraqueza ou inexistência de programas destinados a combatê-la. 
Quando os homens, individualmente, sentem-se impedidos de alcançarem suas expectativas de vida e sociabilidade, de acordo com as idades e grupos de convivência, estão manifestando uma vulnerabilidade que é uma condição repetida entre integrantes das camadas populares.

Quando se acrescentam as relações de gênero como lente para observar esta vulnerabilidade de homens, observa-se uma ocultação do problema, por se tratar de uma esfera caracterizada pelo esforço dos próprios homens de preservarem um discurso de dominação masculina.

Um programa para promover a equidade social e sanar esta vulnerabilidade masculina em certos momentos do curso de vida enfrenta a possibilidade de interpretação crítica das suas ações como realizadas com a intenção de reforçar a dominação masculina. Isto potencializa a intensificação da vulnerabilização programática.

Na primeira parte deste capítulo, dados censitários sobre diferentes tendências na proporção de mulheres e homens residindo em bairros pobres e bairros nobres da cidade do Recife inspiram uma busca de uma interpretação plausível. Na segunda parte, descreve-se a circulação de homens e mulheres entre residências e entre bairros em relação a diferentes faixas etárias, procurando identificar quem controla o fluxo de pessoas e de recursos e a sua relação com a construção de significados para a vivência do espaço da casa, configurando-se como "jogos sérios" (Ortner, 2007, 1996), que resultam em uma vulnerabilização com lados femininos e masculinos, ressaltando o lado masculino. Por fim, procura-se entender parte da relação entre homens e serviços de saúde como relacionada com os processos discutidos, realçando as ideias de vulnerabilidade, circulação e relações de gênero.

\section{Moradia urbana, renda e domicílios}

A divisão da cidade em bairros não é aleatória. É uma delimitação aproximada de territórios entre classes ou segmentos sociais diferenciados, permeada por implicações variadas da vivência de gerações e de gênero na construção de patrimônios domésticos. Quem anda pela cidade identifica rapidamente alguns bairros que ostentam riqueza e outros que denotam pobreza. São várias características que distinguem os bairros, mas, ao procurar um elemento que repetidamente marca as diferenças, nada é mais evidente do que a própria residência. 
Na configuração específica do Recife, isto se vê quando se comparam bairros com altas porcentagens de apartamentos com outros bairros com altas porcentagens de casas.

Em muitos bairros, os proprietários organizaram um esquema de segurança à parte, com portarias, guardas, sistemas de vigilância interna, estacionamentos gradeados, e muitas outras medidas que separam o morador de um contato mais próximo com a rua. As redes de amizade se formam através de contatos telefônicos, Internet, encontros em points de acordo com as preferências das diversas faixas etárias, redes de parentes e de amigos que podem ser acionadas estrategicamente em reforço ao capital social e cultural dos residentes.

A separação física entre apartamentos e entre prédios de apartamentos singulariza, ou particulariza, as redes de sociabilidade, de cordialidade, de trocas, de reciprocidade e de ajuda mútua destas populações. Designam-se aqui como 'bairros nobres', adotando um termo popular que resume a condição destes bairros.

Os bairros com casas individuais não são bairros de pequenas fortalezas domésticas - mesmo que se tente separá-las com muros repletos de cacos de vidro, pregos e ganchos especialmente fabricados para impedir a passagem dos não convidados. Prevalecem nesses bairros habitações modestas, de materiais muito diversos e às vezes precários. Há muito mais interação entre estas casas cujas dimensões são suficientemente limitadas para não estimularem nem um confinamento prazeroso intramuros (como acontece em apartamentos confortáveis e bem aparelhados com móveis e eletrodomésticos diversos) nem um isolamento unirresidencial. A convivência entre vizinhos se agrega aos contatos entre parentes e amigos, formando redes em que a criação de relações de solidariedade, ajuda mútua e 'fofoca' envolvem uma maior coletivização na negociação permanente com os vizinhos, amigos e parentes. Usando os mesmos critérios de nominação para a categoria anterior, estes se designam como 'bairros populares'.

$\mathrm{Na}$ Tabela 1, percebe-se o quanto o tipo de moradia reflete diferenças de nível socioeconômico. Selecionaram-se cinco regiões político-administrativas da cidade do Recife e, com base nos microdados do Censo 2000, bairros contrastantes: o bairro com a maior proporção de apartamentos entre as suas residências particulares (nobre), e o bairro com a maior proporção de casas individuais entre as suas residências (popular). 
Tabela 1 - Proporção de moradia em apartamentos e renda média segundo bairros contrastantes de algumas regiões político-administrativas. Recife -2000

\begin{tabular}{lrrr}
\hline RPA - local/bairro & $\begin{array}{r}\text { Moradia -apartamentos/ } \\
\text { Total de residências }\end{array}$ & Renda média (R\$) & Renda mediana (R\$) \\
\hline Recife (total) & 19,0 & 1.024 & 350 \\
\hline RPA 1 - Soledade & 93,4 & 1.756 & 1.200 \\
\hline RPA 1 - Joana Bezerra & 0,01 & 233 & 151 \\
\hline RPA 2 -Encruzilhada & 53,4 & 1.820 & 1.200 \\
\hline RPA 2 - Peixinhos & 0,01 & 243 & 157 \\
\hline RPA 3 - Graças & 92,1 & 3.658 & 3.000 \\
\hline RPA 3 - Brejo de & 0,001 & 291 & 186 \\
Guabiraba & 44,1 & 1.869 & 1.000 \\
\hline RPA 4 - Madalena & 0,017 & 409 & 239 \\
\hline RPA 4 - Torrões & 78,1 & 3.012 & 2.000 \\
\hline RPA 6 - Boa Viagem & 0,001 & 371 & 250 \\
\hline RPA 6 - Cohab (Ibura) & & & \\
\hline
\end{tabular}

Obs.: 1) Os bairros contrastantes foram escolhidos de acordo com a proporção de moradores em apartamentos, incluindo o bairro com a maior e a menor proporção em cada região político-administrativa. A RPA 5, por não possuir nenhum bairro de marcada presença de apartamentos, não coube na divisão nobre-popular empregada aqui. Os bairros populares, com baixa proporção de apartamentos estão sombreados, e os bairros nobres deixados em branco, para facilitar a leitura comparativa da tabela.

2) As rendas (média e mediana) são do responsável pela família.

Fonte: Com base em dados do Observatório PE (2002).

\section{Geração, patrimônios domésticos e redes}

Para falar de gerações, representando indiretamente diferentes pontos nos cursos de vida, selecionaram-se algumas faixas etárias para ver a proporção que cada uma delas representa no total da população do bairro. Assim, no linguajar dos ciclos domésticos, identifica-se da seguinte forma a proporção da população com faixas etárias que correspondem a fases diferentes pelas quais passam os grupos domésticos:

1) em fases de expansão: primeira infância ( 0 a 4 anos) - casais jovens com filhos pequenos; 
2) em fases potenciais de dispersão: jovens (15-19 anos) - casais de variadas idades com filhos procurando moradias independentes;

3) em fases coexistentes de expansão e dispersão: adultos (40-44 anos) - casais em idade produtiva responsáveis por grupos domésticos com alguns filhos em casa e outros fora;

4) em fases avançadas de dispersão ou substituição: idosos (60-64 anos) - casais e indivíduos vivendo várias recomposições de arranjos domésticos;

5) em fases mais avançadas de dispersão ou substituição: muito idosos (acima de 80 anos) - casais e indivíduos longevos mais sujeitos a dependência e recomposições de arranjos domésticos.

A Tabela 2 e os Gráficos de 1 a 5 apresentam estes dados e, junto com alguns estudos de casos independentes que ressaltam tais questões, servem como base para interpretações de diferenças por meio de registros etnográficos.

Tabela 2 - Gerações, bairro de moradia e porcentagem da população total. Recife -2000

\begin{tabular}{lrrrrr}
\hline RPA - local/bairro & $\begin{array}{r}\text { \% primeira } \\
\text { infância } \\
0-4 \text { anos }\end{array}$ & $\begin{array}{r}\text { \% jovens } \\
15-14 \text { anos }\end{array}$ & $\begin{array}{r}\text { \% adultos } \\
40-44 \text { anos }\end{array}$ & $\begin{array}{r}\text { \% idosos } \\
60-64 \text { anos }\end{array}$ & $\begin{array}{r}\text { \% idosos } \\
\text { acima de } \\
80 \text { anos }\end{array}$ \\
\hline Recife (total) & 8,3 & 10,2 & 6,6 & 2,9 & 1,2 \\
\hline RPA 1 - Soledade & 3,2 & 9,1 & 7,3 & 4,2 & 2,5 \\
\hline RPA 1 - Joana Bezerra & 12,9 & 11,1 & 5,4 & 1,9 & 0,7 \\
\hline RPA 2 - Encruzilhada & 5,3 & 9,4 & 7,1 & 4,4 & 3,0 \\
\hline RPA 2 - Peixinhos & 12,0 & 11,2 & 5,1 & 1,6 & 1,1 \\
\hline RPA 3 - Graças & 4,9 & 10,6 & 8,2 & 3,8 & 2,2 \\
\hline RPA 3 - Brejo de & 10,1 & 11,4 & 5,3 & 2,4 & 0,6 \\
Guabiraba & 6,9 & 9,7 & 7,5 & 2,8 & 1,9 \\
\hline RPA 4 - Madalena & 9,3 & 11,0 & 6,1 & 2,2 & 0,7 \\
\hline RPA 4 - Torrões & 5,8 & 9,8 & 7,6 & 3,7 & 1,6 \\
\hline RPA 6 - Boa Viagem & 9,3 & 11,0 & 5,9 & 2,4 & 0,7 \\
\hline RPA 6 - Cohab (Ibura) & & & & & \\
\hline
\end{tabular}

Fonte: Com base em dados do Observatório PE (2002). 
Como os bairros em contraste por região administrativa variam muito no total da sua população (o menor com 2.201 habitantes e o maior com 100.388), faz pouco sentido agrupar os números para tratar todos os bairros nobres como um bloco e todos os bairros populares como outro bloco. O mais importante é perceber a repetição do padrão de constrastes por região administrativa, de acordo com distribuição de algumas faixas etárias nos diferentes bairros (Gráficos de 1 a 5).

Antes de comentar os dados, é importante ressaltar que o detalhamento dos dados do Censo 2000 não permite o tratamento da idade de acordo com a relação com o responsável pela casa, o que seria ideal para dar mais consistência aos argumentos sobre ciclos domésticos. Os dados censitários dizem respeito à população residente (não a domicílios) e, assim, requerem certa criatividade interpretativa que exige maiores comprovações para que se possa realizar afirmações mais confiáveis sobre estes processos.

Gráfico 1 - Idade em bairros contrastantes de moradia.

RPA 1 - Recife - 2000

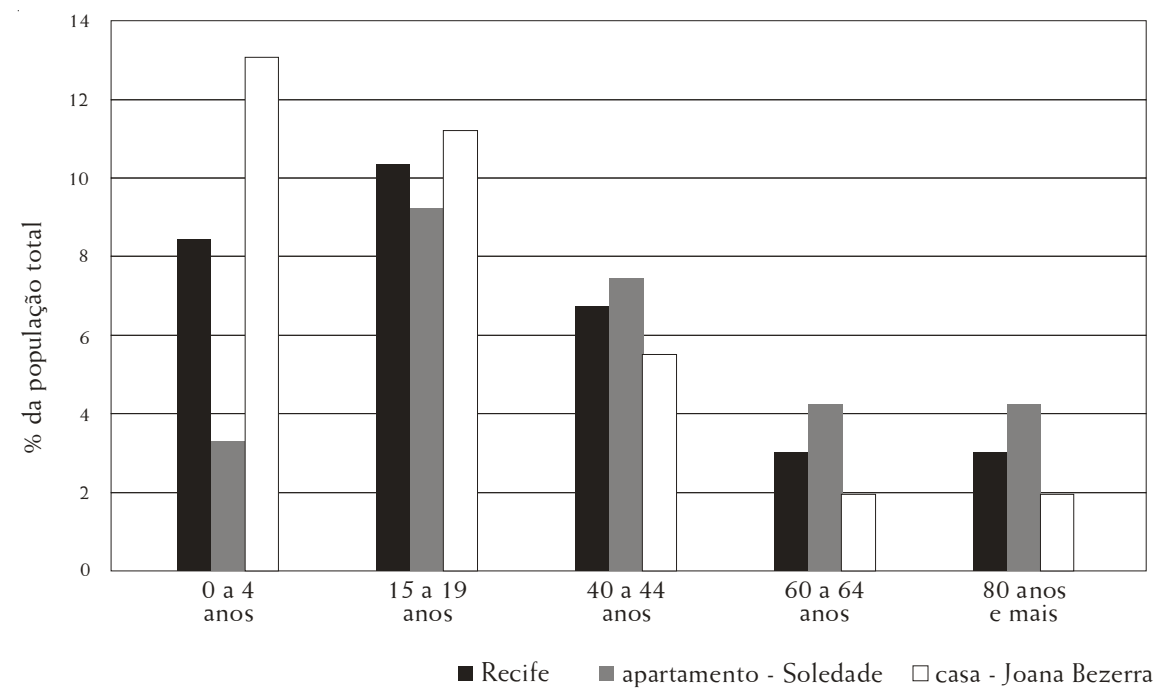

Fonte: Observatório PE (2002). 
Gráfico 2 - Idade em bairros contrastantes de moradia. RPA 2 - Recife - 2000

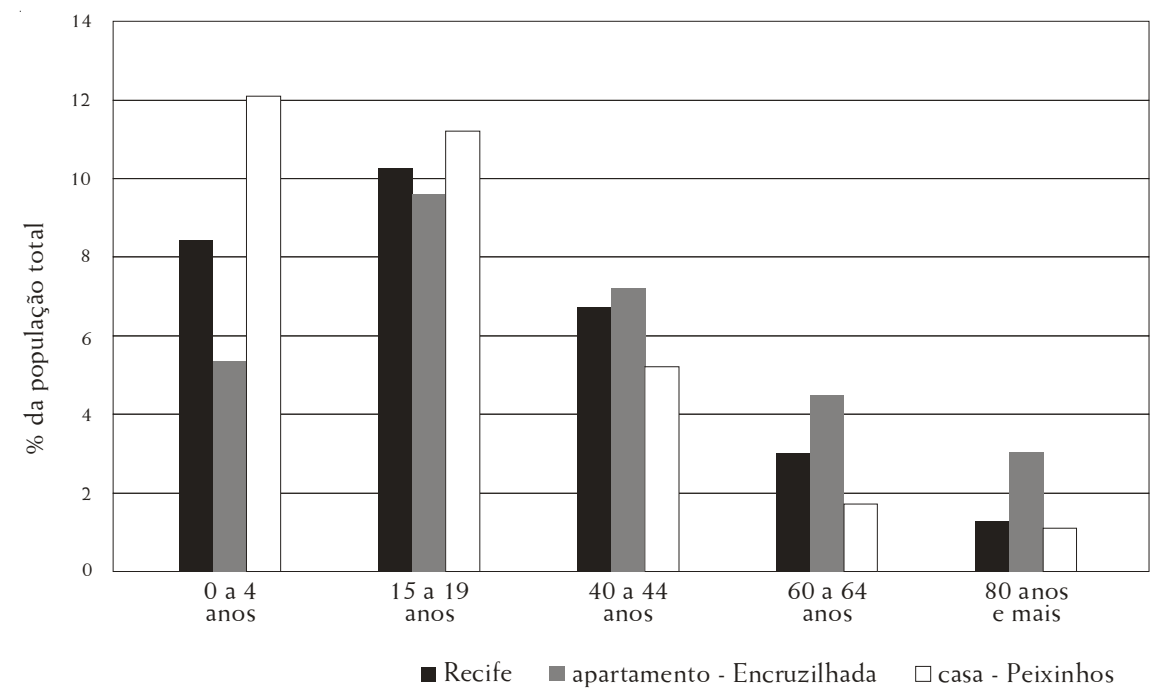

Fonte: Observatório PE (2002).

Gráfico 3 - Idade em bairros contrastantes de moradia. RPA 3 - Recife - 2000

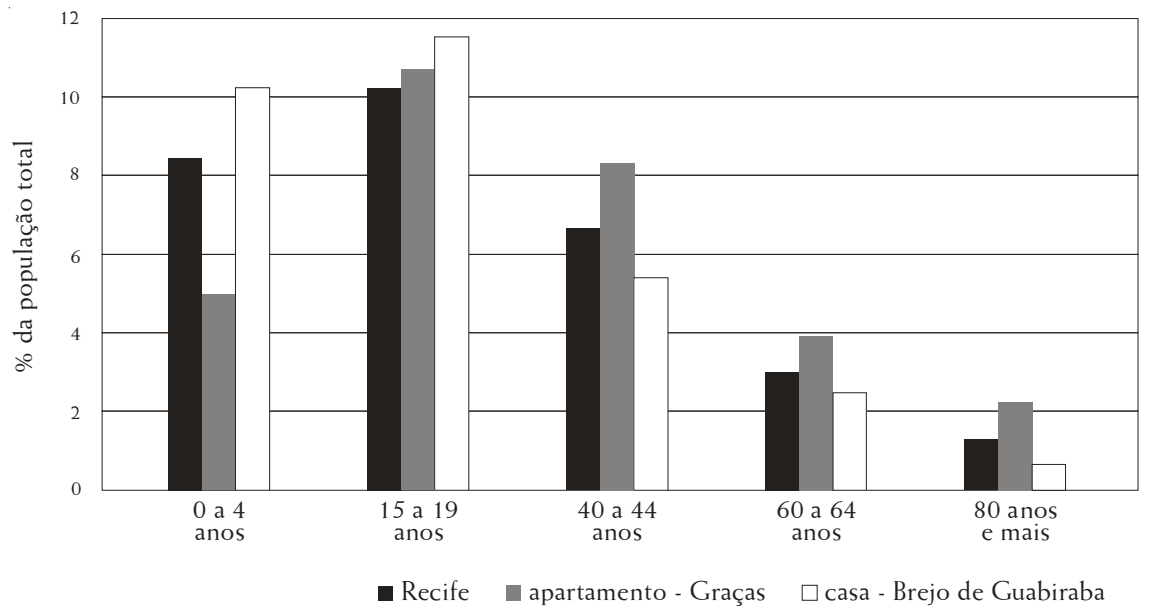

Fonte: Observatório PE (2002). 
Gráfico 4 - Idade em bairros contrastantes de moradia. RPA 4 - Recife - 2000

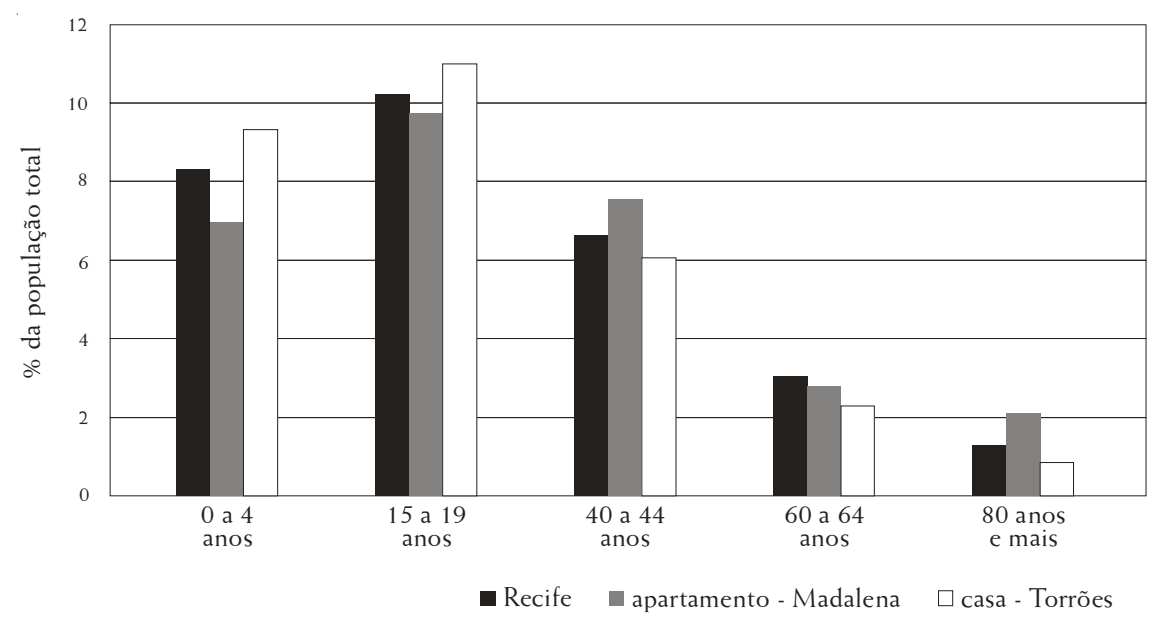

Fonte: Observatório PE (2002).

Gráfico 5 - Idade em bairros contrastantes de moradia. RPA 6 - Recife - 2000

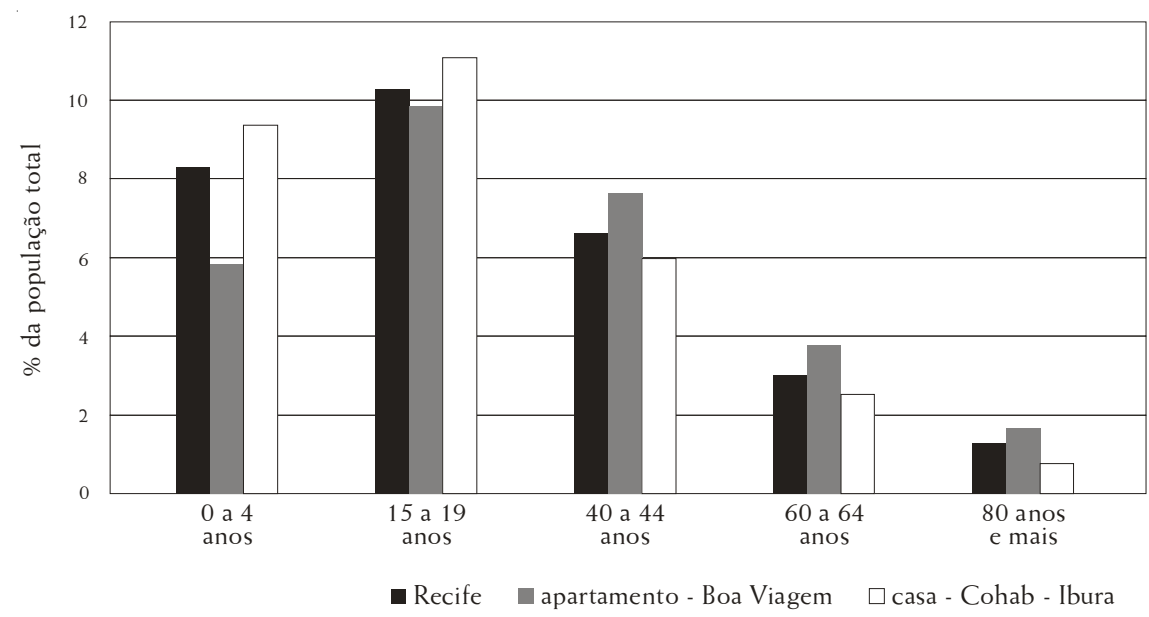

Fonte: Observatório PE (2002).

Atendo-se inicialmente às regularidades em todos os locais, é possível identificar nitidamente a influência da queda de fecundidade em quase todas as populações, refletindo a tendência geral da população total 
da cidade. Desta forma, há mais população jovem (15-19 anos) do que população na primeira infância (0-4 anos). Apenas na Ilha de Joana Bezerra e em Peixinhos é que se verifica uma maior proporção da população na primeira infância do que na juventude. As faixas etárias acima de 40 anos obedecem à clássica estrutura piramidal da população, diminuindo à proporção da população total com o avanço da idade.

Os contrastes entre os bairros nobres e bairros populares são extraordinariamente repetitivos. Veja por faixa etária.

A presença de uma maior proporção de pessoas entre $0-4$ anos implicaria um maior número de domicílios em fase de expansão e uma sobrecarga nos jovens pais responsáveis por estas casas. Nos bairros populares, estes números relativos de jovens presentes são sistematicamente maiores do que nos bairros nobres, inclusive sendo proporcionalmente mais do que o dobro em três dos cinco pares de bairros comparados.

Quando se passa para os jovens de 15-19 anos, que podem estar estudando, trabalhando, procurando trabalho, namorando, formando casas próprias ou se mantendo nas casas dos pais, as proporções de jovens entre a população dos bairros nobres e os populares se aproximam levemente, ainda que os populares detenham maiores proporções. Os bairros populares sempre estão ligeiramente acima da média para o Recife como um todo em quantidade de jovens, ao passo que os bairros nobres sempre estão ligeiramente abaixo dessa média.

Isto pode sugerir que, entre 1980 e 1985 , a queda da fecundidade ainda não tivesse marcado tão profundamente a estrutura da população, e que tanto a população dos bairros populares quanto a dos bairros nobres precisam lidar com um contingente razoável de jovens e das suas demandas (pelo menos em 2000). Em outro estudo, com esta mesma base de dados, verificou-se que é na faixa de 20 a 24 anos que a população dos bairros nobres começa a ultrapassar, proporcionalmente, a dos bairros populares (Scott \& Franch, 2004).

As razões de isto ocorrer nesta faixa etária não são claras nos dados em si, mas, entre as possibilidades, há: 1) fluxos migratórios de mais jovens populares à procura de empregos em locais mais distantes dos bairros, 2) a permanência de jovens, para continuarem os estudos, na casa dos pais nos bairros nobres; 3 ) uma maior mortalidade entre os jovens dos bairros populares. Estes processos são determinantes para o que se discutirá mais adiante. 
A faixa da população de 40 a 45 anos está em plena idade adulta e aproxima-se ao final da sua idade reprodutiva, se esta não tiver sido encerrada, via ligaduras, em idades mais novas, para as mulheres, e via vasectomia, para os homens. Nos bairros nobres, esta população adulta está sempre acima da proporção da mesma idade que mora em bairros populares, como se vê na Tabela 2. Nela, pode-se observar que, nos bairros nobres, a população dessa idade oscila entre $7,1 \%$ e $8,2 \%$ da total do bairro, ao passo que, nos bairros populares, a oscilação se dá entre $5,1 \%$ e $6,9 \%$. A menor fecundidade entre os residentes de bairros nobres permite que tenham um menor número de dependentes e favorece uma inserção mais favorável em atividades produtivas. As migrações intraurbanas e menor longevidade podem fornecer uma explicação parcial para esta diferença.

Juntando-se as duas faixas de população mais idosa, fica ainda mais nítido que o envelhecimento populacional amplia o número de gerações e provoca novas arrumações da vivência entre gerações, o que já foi reconhecido por diversos pesquisadores (Goldani, 1993; Debert, 1999; Berquó, 1999; Peixoto, 2004; Scott, 2001, 2002). Estas novas articulações afetam o cotidiano de residentes pobres e mais ricos, apresentando-se com muito mais clareza e peso para as populações dos bairros nobres.

Ocorre a inversão da tendência evidenciada na comparação entre os moradores de bairros populares e nobres para a população mais nova na maior parte dos bairros nobres, contrastados com os bairros populares, a proporção de idosos na população é mais do que o dobro. O contraste visto desde a faixa etária de 60 a 65 torna-se muito mais evidente entre as populações muito mais idosas (acima de 80 anos), como se verifica na Tabela 2. Assim, nos bairros populares, a convivência com os idosos não deixa de apresentar desafios, mas estes estão proporcionalmente menos presentes do que nos bairros nobres.

Estes contrastes etários dão uma ideia de vivência de ciclos domésticos e cursos de vida entre gerações que pode ser muito bem pesquisado através de estudos de casos e estudos etnográficos. Não cabe fazer este exercício completo aqui, mas sim apontar a relação entre geração e gênero e suas implicações para a compreensão da vulnerabilidade masculina na idade adulta. Cabe, no entanto, na busca por dados relativamente mais 'imponderáveis', tentar por um pouco de 'carne etnográfica nos esqueletos' de dados censitários. Neste exercício, se recorre mais a casos investigados pelo autor, sem querer desmerecer a grande quantidade de excelentes estudos de outros pesquisadores sobre o tema. 
Descobrir onde moram crianças, jovens, adultos e idosos em relação à família não é fácil sem recorrer a dados concretos sobre a relação com o responsável da casa. Ainda falta encontrar, para os bairros, dados abrangentes e aprofundados que detalhem as condições das diversas faixas etárias, das suas casas e das suas famílias. Mas é possível fazer algumas observações com base em outros estudos realizados em alguns locais específicos e em outros contextos no Brasil.

Como o casamento das moças ocorre mais cedo que o dos rapazes, elas tendem a formar residências próprias mais jovens do que eles. Os rapazes passam mais tempo residindo com os pais. Dados mostram que há uma maior proporção de filhos homens entre 20 e 24 anos morando com os pais do que de filhas. ${ }^{3}$ É difícil identificar, numericamente, as proporções de jovens casados, ou de pais e avôs, que residem em quartos nas casas dos pais, sogros e filhos, respectivamente. $\mathrm{O}$ registro destas famílias 'corresidentes' ${ }^{\prime}$ é muito precário, pois depende da identificação ou não de uma "entrada separada" por um recenseador (Berquó, 1988). Muitas pessoas que "moram nos fundos" e participam no dia a dia de refeições e tarefas podem ser identificadas pelos recenseadores como residindo em casas independentes quando não são, de fato, tão 'independentes'.

Fazendo referência a estudos prévios e novas etnografias, Louis Marcelin (1999) e Gabriella Hita (2006) ressaltam um padrão, muito bem conhecido em todo o Brasil, da passagem de vários anos, após a constituição de um novo casal, em que as novas famílias residem com as famílias de origem, antes de reunirem condições para morar à parte. Tal padrão tem sido constantemente observado em bairros populares onde se ressalta a formação de pequenos conglomerados de casas proximamente aparentadas e com redes de sociabilidade internas muito estreitas que terminam por influenciar a maneiras pelas quais os jovens adquirem habilidades e conhecimentos, evidenciadas, para o caso do Recife, na pesquisa Os Jovens e a Cidade (Dalsgaard, Franch \& Scott, 2008; Scott \& Franch, 2004; Gough \& Franch, 2003).

3 Eduardo Rios Neto (1988) observou esta tendência num estudo apresentado oralmente (não publicado), em seminário conjunto da Associação Brasileira de Estudos Populacionais (Abep) e da Associação Nacional de Pesquisa e Pós-Graduação em Ciências Sociais (Anpocs), em Campinas, sobre a família no Brasil. Tal tendência confirmou-se em dados posteriores analisados por Ana Amélia Camarano (1999, 2004).

4 Heraldo Souto-Maior (1992) é dos poucos autores que examinaram essa situação com mais detalhe. 
Tomando-se a faixa dos idosos, outros estudos (Scott, 2002, 2008; Camarano, 1999) mostram a tendência de o brasileiro mais idoso (especialmente as mulheres) residir como dependente na casa de outros. Em um bairro popular no centro do Recife, nos anos 80, havia oito vezes mais mulheres idosas que homens idosos residindo com os filhos ou com outras pessoas (Scott, 1990), tendência observada também em estudos mais recentes (Lages, 2007; Scott, 2008).

Esta dinâmica populacional, intra e interdoméstica, tem estreita relação com processos diferentes de construção de patrimônios de pessoas de bairros e condições sociais diferentes.

Em um estudo de trocas materiais e relacionais entre pais e filhos em famílias recifenses com patrimônios bem diferentes (pobres e ricos), as famílias pobres costumavam formar residências independentes para os filhos mais cedo que as famílias ricas. As famílias ricas mantinham os filhos solteiros em casa por mais tempo e ofereciam condições para eles poderem compartilhar o uso do patrimônio familiar (acesso a carros, dinheiro para festas, equipamento para estudos etc.) e investir mais na instrução formal (Peres da Costa, 1983).

A prática de retardar a dissociação dos filhos da família de origem estimula uma participação maior destes na herança de uma administração de um patrimônio, o que vai permitir a inserção favorável dos jovens nos contextos de convivência com os pares das suas próprias camadas sociais, mantém os seus filhos sob vigilância, permitindo a reprodução do seu capital cultural e social e a ideia de autonomia, como observa Kátia Araújo (1984).

Entre os jovens mais pobres, o poder do simbolismo do patrimônio autônomo de cada grupo doméstico se evidencia menos, e a importância de manter as redes sociais alargadas para poder contar com a colaboração de família e amigos, atualmente e no futuro, se ressalta. Este período de juventude é, então, um período da formação de condições para a passagem do patrimônio material e simbólico que se forma no meio de uma tensão entre a liberdade e a autonomia individuais tão procuradas pelos jovens (seja como solteiros ou como casados) e a reafirmação do seu pertencimento a grupos de parentesco e a famílias cujas estratégias de manutenção de patrimônios exigem uma continuidade de trocas entre pais e filhos. Onde residir é apenas uma das manifestações de como isto se realiza.

A direção do fluxo de apoio financeiro entre pais e filhos que moram distantes uns dos outros evidencia que o patrimônio se constrói no fluxo e circulação de recursos entre pessoas que residiam anteriormente na 
mesma casa. A famosa frase do filho da família de camada média "papai, mande dinheiro, que estou precisando!" denuncia tal fluxo. Isto não é tão evidente quando se enfocam as remessas e as visitas entre emigrantes menos abastados e as suas casas de origem. Um estudo (Scott, 1984) identificou que a 'moeda de troca' entre grupos domésticos relacionados é, sobretudo, de filhos para os pais e pode ser diferente de acordo com gênero: rapazes e moças solteiras e rapazes casados emigrados ${ }^{5}$ mandavam dinheiro, moças casadas deixavam de mandar, mas abriam as portas das suas casas para irmãos e irmãs e outros parentes terem um espaço para buscar oportunidades.

Quando a migração é intraurbana, costuma ser mais feminina, e tanto a idade de casamento quanto a oferta de emprego doméstico permitem que as mulheres jovens estabeleçam um ponto de apoio para a construção de seu patrimônio fora do bairro de origem.

\section{Gênero e moradia e faixas etárias}

Quando se agregam dados sobre gênero às questões de faixas etárias apresentam-se, além das evidências de tendências já bem documentadas, algumas questões bastante instigantes que requerem mais investigação. Os contrastes entre os bairros no que diz respeito a gênero estão apresentados nos Gráficos 6 a 10.

A maior natalidade masculina, acoplada à sua maior mortalidade, faz com que a progressiva feminilização das faixas etárias não seja surpreendente. Apenas reafirma tendências reconhecidas há muito tempo.

Quando se trata da diferença entre bairros nobres e populares, entre a faixa de idade de 0 a 4 anos não ocorre nenhum favorecimento masculino ou feminino de um ou outro tipo de bairro. Embora não apareça no nascimento, esta não é a situação quando se trata da população total.

Os bairros nobres são marcadamente mais femininos do que os bairros populares. Esse fato nos leva a indagar: ocorre um fenômeno de feminilização da riqueza ou, inversamente, de masculinização da pobreza? Isto provoca a necessidade de uma interpretação, especialmente diante da conhecida ênfase na literatura sobre a feminilização da pobreza!

5 O estudo focalizou famílias recifenses e maranhenses e migrações para o Norte e para o Centro-Sul. 
É importante esclarecer novamente que os dados são sobre a população e não sobre os domicílios, e os trabalhos sobre a feminilização da pobreza mostram como as rendas familiares de mulheres estão abaixo das médias para homens. Sem os dados sobre a posição na família, não se sabe que condição estas mulheres têm na casa - se são chefes, esposas, filhas, mães, netas, irmãs, ou até empregadas. Seria muito útil ter estes dados para interpretar a relação entre essa tendência e a inserção dos diferentes cursos de vida em ciclos domésticos diferenciados.

Não cabe dúvida de que a convergência da maior longevidade feminina com a maior longevidade de pessoas mais prósperas contribui para elevar a presença feminina nos bairros nobres, e em posições de autoridade, como aquelas que têm sido analisadas por Myriam Lins de Barros (1987), Guita Debert (1999), Maria Angélica Motta-Maués (2004) e Clarice Peixoto (2004). Pelo menos fica como alerta sobre a necessidade de entender como estas mulheres estão integradas nas próprias famílias, redes de parentesco e domicílios. Mas a relação entre gênero e a distribuição intraurbana da população é mais complexa do que isto.

Gráfico 6 - Mulheres (\%) por faixa etária em bairros de moradias contrastantes. RPA 1 - Recife - 2000

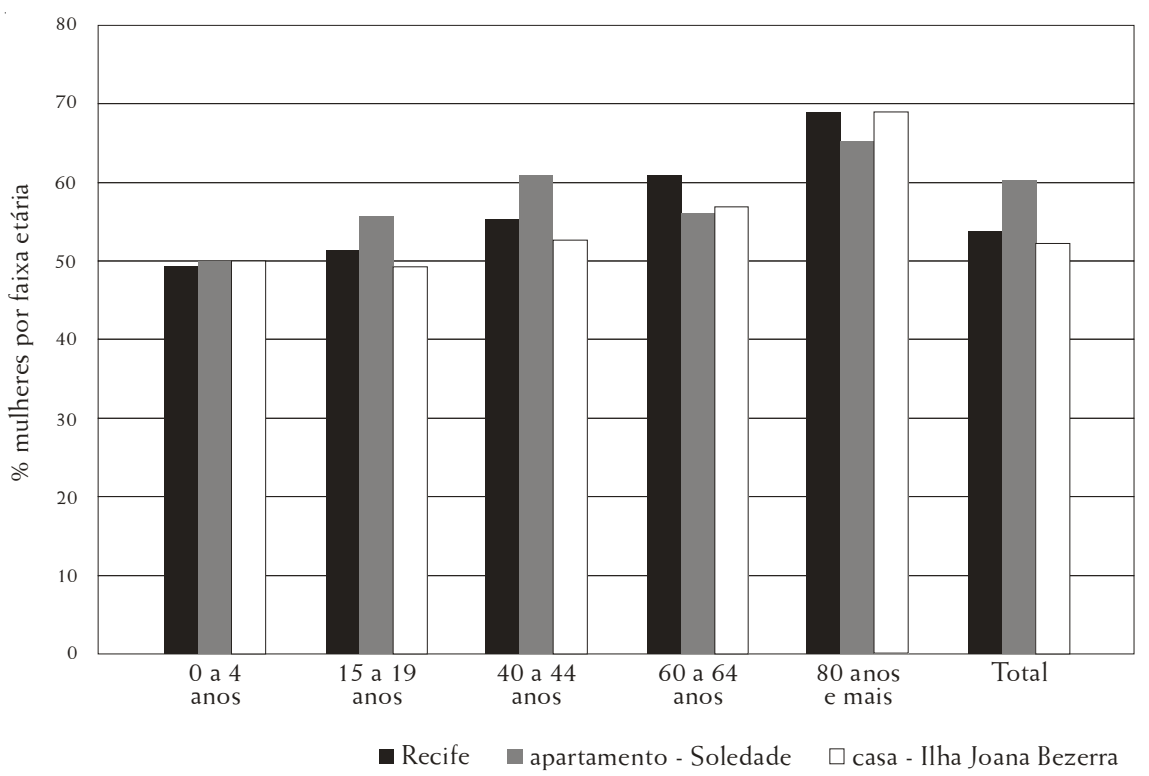

Fonte: Observatório PE (2002). 
Gráfico 7 - Mulheres (\%) por faixa etária em bairros de moradias contrastantes. RPA 2 - Recife - 2000

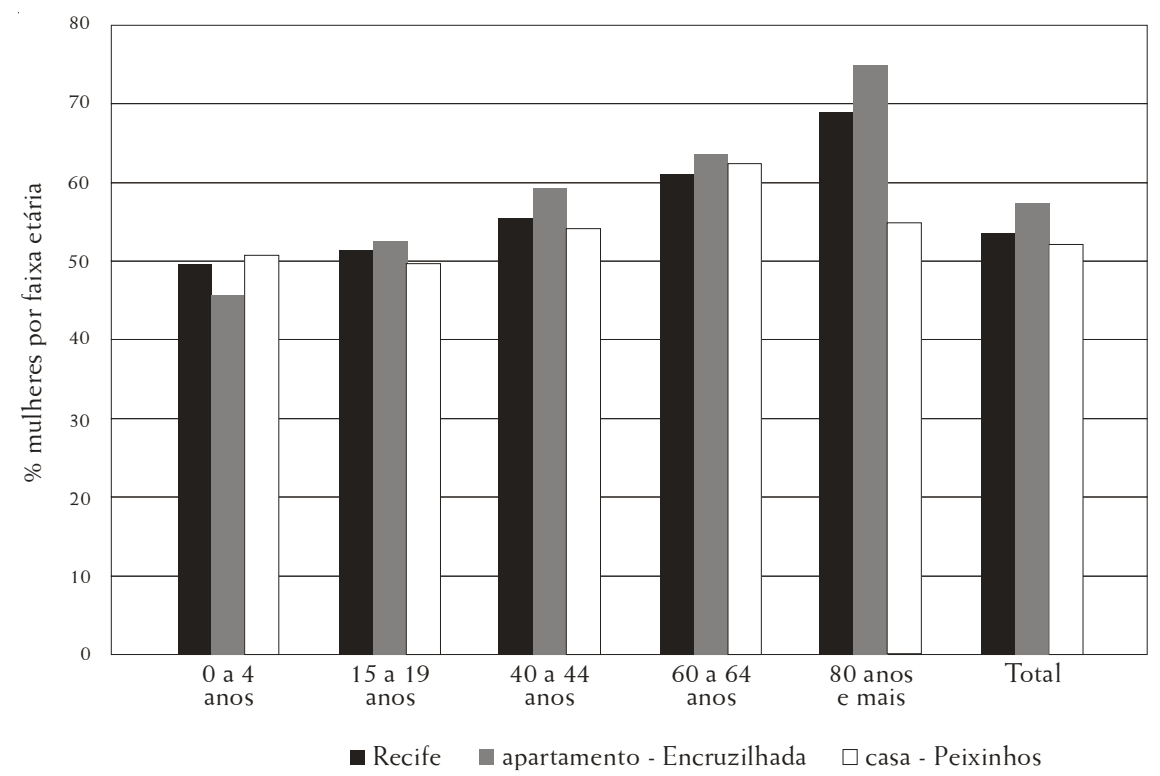

Fonte: Observatório PE (2002).

Gráfico 8 - Mulheres (\%) por faixa etária em bairros de moradias contrastantes. RPA 3 - Recife - 2000

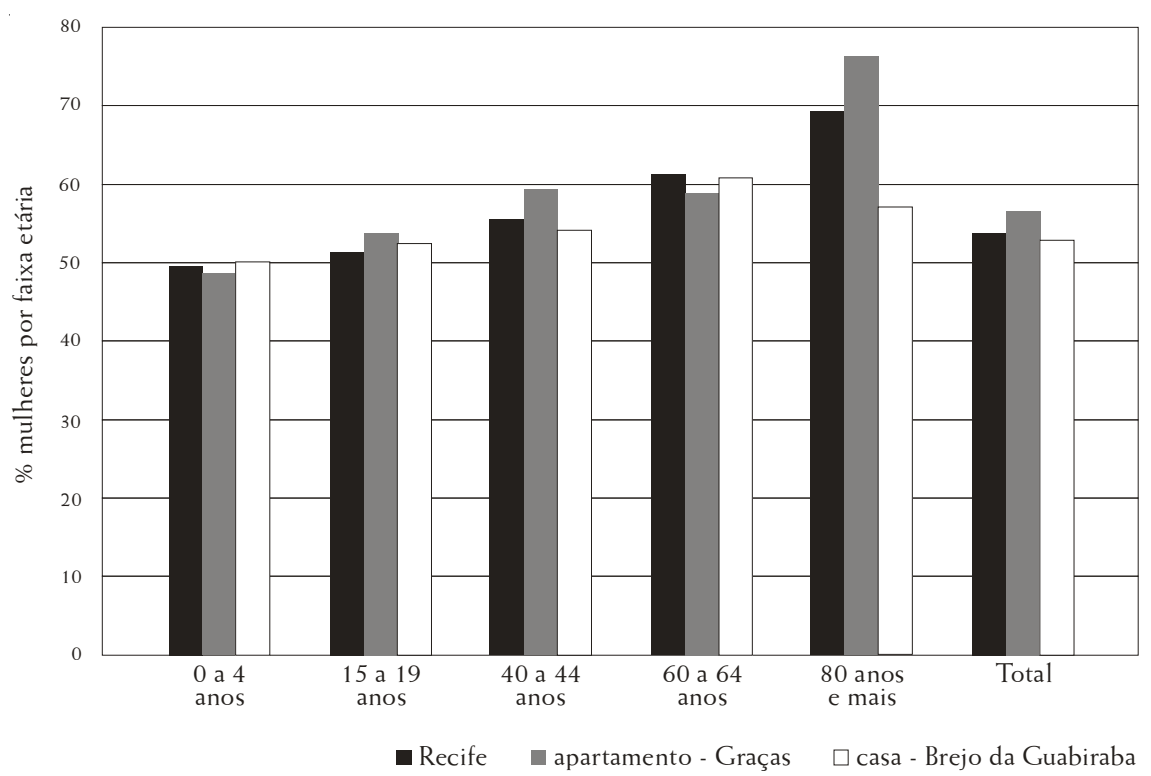

Fonte: Observatório PE (2002). 
Gráfico 9 - Mulheres (\%) por faixa etária em bairros de moradias contrastantes. RPA 4 - Recife - 2000

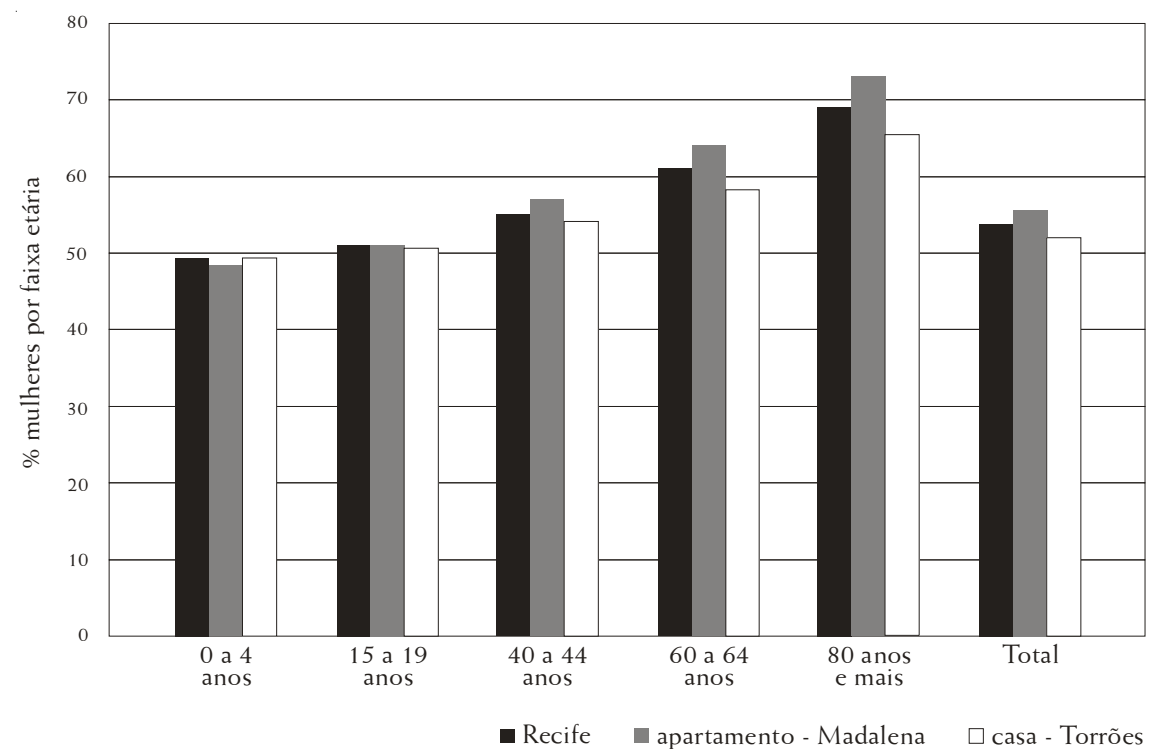

Fonte: Observatório PE (2002).

Gráfico 10 - Mulheres (\%) por faixa etária em bairros de moradias contrastantes. RPA 6 - Recife - 2000

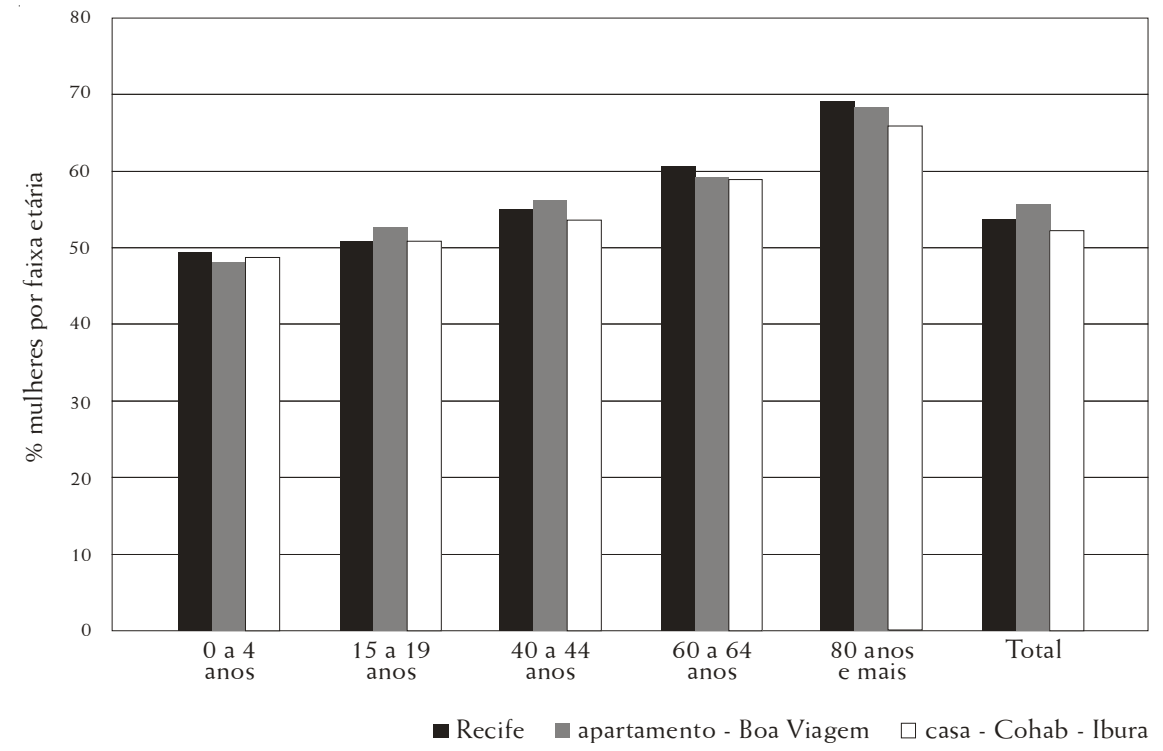

Fonte: Observatório PE (2002). 
Os Gráficos 11 e 12 tratam das diferenças na distribuição de mulheres e homens entre bairros nobres e bairros populares das regiões políticoadministrativas do Recife, de acordo com três faixas etárias (15-19, 40-44 e 60-64 anos).

$\mathrm{Na}$ faixa etária de 15 a 19 anos, quatro dos cinco bairros com maior presença masculina entre os jovens são bairros populares. Isto surpreende diante da alta mortalidade masculina juvenil. Nos bairros nobres, há um pouco mais de mulheres do que de homens. Com os dados disponíveis, não há como comprovar a que isto se deve, mas é provável que haja um ingresso maior de mulheres jovens nos bairros nobres através de pelo menos dois processos: emprego doméstico com moradia e casamentos hipergâmicos das jovens populares, com patrilocalidade ou neolocalidade.

Se não bastasse esta transferência de mulheres para bairros mais nobres que os da sua origem (se, de fato, este é o processo), quando se procura ver a situação dos adultos entre 40 e 44 anos, mais uma vez, e ainda com mais força, se percebe uma masculinização relativa dos bairros populares e feminilização mais intensiva dos bairros nobres.

Gráfico 11 - Porcentagem de mulheres na população por idade entre bairros nobres e populares. Recife -2000

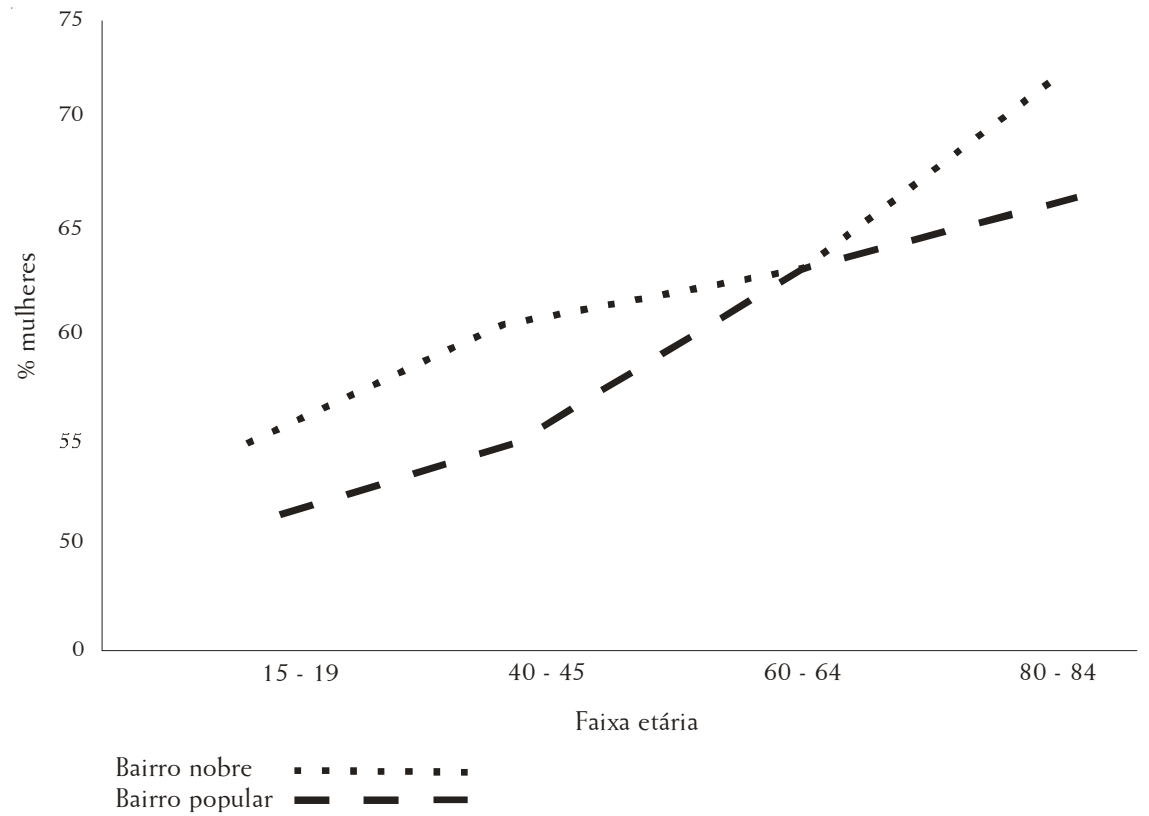

Fonte: Com base em dados do Observatório PE (2002). 
Gráfico 12 - Superávit de mulheres em bairros nobres, comparados com bairros populares (\%). Recife - 2000

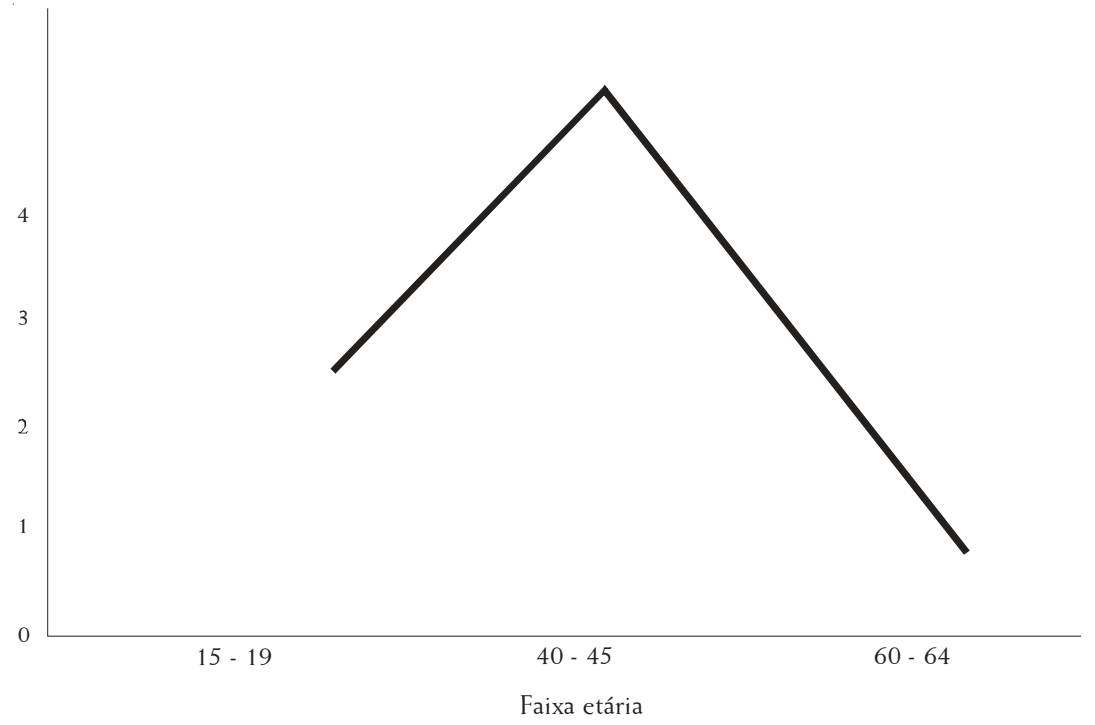

Obs.: Com base nos resultados de cinco RPAs do Recife, estabeleceu-se a média do superávit proporcional de mulheres em bairros nobres com a seguinte fórmula: (\%MBN-\%MBP= $\triangle$ ), em que $B N=$ Bairro nobre, $B P=$ Bairro popular, $\% M=$ Proporção de mulheres, $\Delta=$ Diferença de porcentagens entre os bairros.

Fonte: Com base em dados do Observatório PE (2002).

Observando as comparações entre bairros das mesmas regiões político-administrativas de Boa Viagem para os bairros mais populares, denominados no censo de Cohab/Ibura, a diferença também existe, mas é relativamente pequena (2,3 pontos percentuais), ao passo que entre a Ilha de Santa Joana e o bairro de Soledade a diferença é muito mais marcante $(8,2$ pontos). Se os processos de transferência da população feminina forem idênticos aos que se descreveram ao falar dos jovens, a divisão da população feminina e masculina entre bairros nobres e populares evidencia processos que podem ser vistos por pelo menos dois ângulos diferentes: as mulheres estão conseguindo permear as barreiras da pobreza e mudar para bairros mais nobres; as mulheres estão sendo incorporadas nas casas dos bairros mais nobres para trabalhar sem haver claro benefício para elas.

Nesta situação, os homens dos bairros populares precisam investir mais esforço relativo para garantir o sustento das suas famílias. Eles não conseguem mudar-se para bairros nobres por causa do receio dos moradores 
desses bairros de incluí-los nas suas residências, como trabalhadores ou como empregados. E as empregadas, quando parceiras de maridos moradores em bairros populares, podem estar contribuindo com importantes remessas de ganhos auferidos por serviços prestados em casas de bairros nobres.

Há um fator evidente no Gráfico 11 que é preciso ressaltar aqui: o envelhecimento populacional. As mulheres são mais longevas do que os homens, e as populações com mais renda são mais longevas que as populações com menor renda. Isto implica que haja mais mulheres nos bairros nobres, como se pode observar nos Gráficos de 6 a 10, onde a população mais velha geralmente é mais feminina quando comparada com a dos bairros populares.

Seria muito precipitado atribuir a redistribuição a este fator, pois, ao se observar o Gráfico 12, constata-se que a redistribuição é mais intensa na faixa etária de 40 a 45 anos do que na de 60-64 anos, sugerindo que não seja o simples processo de mortalidade diferencial progressiva por sexo no envelhecimento que explique o fenômeno.

Então, há outras questões em jogo também, como já se argumentou. Isto levanta dois problemas para entender as diferenças nos dados, um de confiabilidade de dados, e outro de interpretação do que eles mostram.

Em primeiro lugar, aborda-se a confiabilidade dos dados. No Manual do Recenseador (IBGE, 1999), informa-se que a data de referência do Censo é a noite de 31 de julho para o $1^{\circ}$ de agosto.

Sempre respaldado nos conceitos do IBGE, que variam ligeiramente nas versões dos manuais dos censos (IBGE 1999, 2000), o recenseador recebe as seguintes instruções:

Domicílio é uma habitação estruturalmente separada e independente, que se destina a servir de habitação de uma ou mais pessoas, ou que esteja sendo utilizada como tal. (...) os critérios essenciais desta definição são os de separação e independência. (...) devem ser considerados partes integrantes do domicílio os quartos providos de entrada independente e as construções anexas à principal, utilizados por membros do domicílio, inclusive empregados domésticos, desde que não fique caracterizado o critério de separação. (IBGE, 2000: 24)

A variabilidade da definição nos censos, conforme se vê em IBGE (2000: 28-29) está na referência a condições que permitem uma flexibilidade que se reporta ao que o recenseador e o recenseado entendem como a "habitualidade do uso" e o "tempo de permanência nos últimos doze meses". 
A ideia de "habitualidade" permeia os esclarecimentos no manual (IBGE, 2000: 25-29). Nestas páginas ainda há um esclarecimento sobre a necessidade de incluir empregadas domésticas nos seus locais habituais de residência, o que, na prática, não garante a não duplicidade ou omissão de referência a elas.

Logo a seguir, lê-se uma ressalva importante:

A pessoa que, na data de referência, por conveniência ou obrigação, dormiu no local do trabalho (empregado doméstico, médico, enfermeiro, militar, trabalhador de obras, trabalhador agrícola sazonal etc.), mas que, habitualmente, retorna à sua residência, deve ser recenseada no seu domicílio. (IBGE, 2000: 29)

É importante ressaltar que um critério para decidir quem é do domicílio é o que se entende como uma "entrada privada" do espaço domiciliar. Determinado isso, empregam-se critérios entre os quais há uma margem para interpretações divergentes: moradia habitual, separação, independência e a data de referência do censo. O manual é taxativo que o censo se refere à data de 31 de julho como crucial, mas acrescenta a 'habitualidade' de retorno à residência pela pessoa que trabalha e dorme no emprego no período de 12 meses.

Assim, adotados estes critérios, seriam contadas como residentes nos bairros populares as empregadas que habitualmente dormem no emprego, mas que fazem visitas "de folga" semanal, quinzenal ou mensalmente nas suas casas no bairro popular. Mesmo diante de tantos esclarecimentos, a habitualidade da moradia, essencialmente, é deixada no Censo ao critério do entrevistado, da maneira que é entendida pelo recenseador, circunscrita tecnicamente pela regra do intervalo máximo de 12 meses sem retornar à moradia 'habitual'. De uma forma mais simples, nem sempre está claro qual é a moradia habitual de uma empregada que somente vai para casa nas férias ou muito poucas vezes.

Quais as implicações desta descrição detalhada para a leitura dos dados da distribuição da população por sexo entre bairros? A pergunta é como os dados técnicos poderiam contribuir para entender a feminilização de bairros nobres nas faixas de idade adulta plena ( 40 a 45 anos): idealmente, somente aquelas empregadas que estabeleceram residência habitual na casa das patroas contribuiriam para o superávit feminino em bairros nobres. E cabe observar que empregadas nessa situação são poucas e estão em processo de diminuição (Ávila, 2009). Ou seja, é improvável que "dormir no trabalho" explique a maior parte da diferença. 
Em relação aos bairros nobres, poder-se-ia admitir que os patrões ou as patroas, na condição de responsáveis pela residência, seriam os informantes sobre a habitualidade domiciliar das suas empregadas, preferindo sublinhar a dependência delas à sua casa e desprezando o laço com outras casas às quais elas estejam vinculadas, mesmo que as empregadas voltem com frequência a esses locais. Em relação aos bairros populares, outras pessoas facilmente podem ser entrevistadas como responsáveis pelos domicílios. Estas podem omitir as visitas regulares de empregadas que trabalham fora, entendendo que a "habitualidade residencial" deve ser mais associada ao local de trabalho da empregada, mesma que ela tenha um papel importante no sustento da casa no bairro popular para onde volte com frequência ou regularidade. Sem pesquisa direta específica, não há como estimar com confiança o peso destes fatores, mas a direção seria de algum aumento no registro de mulheres em bairros nobres.

Mais difícil ainda de aferir sem pesquisa específica é a hipergamia com patri ou neolocalidade-mulheres casando-se com homens em melhores condições financeiras e mudando-se para bairros com rendas médias mais altas, comentado anteriormente, mas com alguns desdobramentos importantes. Este procedimento retiraria mulheres dos bairros mais pobres e explicaria parcialmente a maior presença relativa de homens neles, já que o caminho de hipergamia masculina é muito menos frequente. Em um estudo sobre renda e chefia na Zona da Mata de Pernambuco, uma situação análoga foi encontrada, com homens sozinhos mais velhos apresentando a situação de maior vulnerabilidade econômica (Scott, 1998). No Recife, em bairros populares, então, haveria homens desempregados - filhos ficando em casa ou morando no mesmo bairro, e maridos e homens sem cônjuges também enfrentando menos opções de residência extrabairro.

Pelas pesquisas de migrações já realizadas (Scott, 1984; Arizpe, 2007), quando uma mulher estabelece uma nova residência, ela é mais propensa do que o homem a, logo em seguida, agregar outros parentes e amigos, preferencialmente mulheres, à sua residência. Homens convidam menos outros parentes e amigos para residir juntos depois de formarem um domicílio independente. Parcialmente, em função de perdurar a divisão de trabalho doméstico, as mulheres convidam quem possa ajudar no apoio ao cuidado de filhos ou na realização de trabalho em casa. Assim, a hipergamia feminina teria um efeito multiplicador na saída de mulheres de bairros populares.

Há também os efeitos morais do androcentrismo que poderiam contribuir para explicar o registro de uma distribuição diferenciada. Nos 
bairros populares, sobretudo, estes resultam da possibilidade de haver uma duplicidade na contagem de homens que residem com uma mulher como esposa e que mantêm outro domicílio com outra mulher nas proximidades, geralmente no mesmo bairro popular.

As 'outras', como entrevistadas, podem declarar a presença habitual desse marido nas suas casas justamente para mostrar que não são mulheres 'sem homens', assim produzindo um efeito de reificação, em nome de androcentrismo, de uma supercontagem masculina em bairros populares ao informar a presença do homem como 'morador' da casa, que também é marido em casa de outra mulher. Moralmente, os homens podem tirar proveito de serem reconhecidos como tendo duas famílias, mas para as mulheres tal constatação devasta a sua reputação.

Um último fator pode estar relacionado ao fato de que a renda proveniente do trabalho doméstico permite que a mulher passe a residir em um bairro de renda ligeiramente mais alta, retirando-se do bairro mais pobre e promovendo a ida de mulheres cuidadoras, associadas à sua rede particular (avós, irmãs, tias, filhas maiores, entre outras), para o novo domicílio (semelhante ao fenômeno descrito para hipergamia feminina).

Embora a compreensão deste circuito de redistribuição da população entre os bairros populares e nobres possa ser considerada inconclusa, é muito provável que os dados de maior presença feminina em bairros nobres estejam relacionados em parte aos fenômenos descritos, e não apenas ao envelhecimento populacional.

\section{Interpretando vulnerabilidade masculina, circulação feminina e cursos de vida}

A primeira constatação sobre a limitada confiabilidade dos dados é que o fenômeno de distribuição desigual de sexo entre bairros nobres e bairros populares, mesmo sendo importante para as faixas etárias investigadas, está sub-representada. Isto porque as regras de contagem censitária, aplicadas corretamente, escondem a convivência das empregadas de bairros populares nos domicílios das suas patroas onde elas passam muito tempo.

Trabalho doméstico, o que mais ocupa as mulheres de baixa renda (Ávila, 2009) se concentra nas idades em questão (15-19 e, sobretudo, 40 a 44). Quem controla o mercado de trabalho são as patroas, mulheres de bairros nobres (como também de outros bairros) que oferecem os postos de trabalho e negociam a disponibilidade de tempo, muito em desvantagem 
das empregadas. Elas determinam a intensidade da qualidade clientelística da relação, oferecendo doações, favores e outros recursos além da remuneração contratual (Ávila, 2009 e Jelin, 1994).

A oferta dos 'outros recursos' costuma vir acompanhada por um discurso que instaura e relembra a natureza hierárquica da relação entre patroa e empregada. Nesta negociação, os ganhos certamente recaem mais para as patroas. Tais ganhos são auferidos na forma de cálculos econômicos, mas também na forma da construção de capital social e cultural. Ou seja, a presença de mulheres trabalhando em bairros nobres permite que as mulheres e homens empregadores nestes bairros possam auferir mais benefícios ao não se dedicarem a trabalhos pouco valorizados que são realizados pelas empregadas. Em outras palavras, o superávit feminino em bairros nobres permite um fluxo de recursos duplo, que favorece os patrões.

Os ganhos decorrentes dessa troca desigual ainda têm desdobramentos ao serem repassados para as redes estabelecidas em bairros populares. Por mais parcos que sejam estes ganhos e por mais exigentes que sejam as condições impostas pelas patroas, representam ingressos regulares que servem para a sustentação não somente da própria empregada, mas, pelo menos parcialmente, de outras pessoas que dependem dela.

Nos bairros populares, os resultados deste trabalho são de perpetuar redes de alianças entre familiares e amigos que favorecem muito mais a inclusão de mulheres que podem servir como substitutas de mães durante as ausências das mulheres que trabalham e/ou residem fora do bairro.

Homens a quem se exige trabalho doméstico para ajudar a mãe que trabalha, mesmo se elogiados por elas quando se dispõem a fazê-lo, enfrentam eventuais chacotas da vizinhança e inevitavelmente passam por um questionamento da sua masculinidade. Maridos também, com o agravante de que a inclusão em um circuito desses pode redundar, pelo menos para algumas mulheres, numa perda do valor simbólico da presença masculina na casa, do ponto de vista das próprias empregadas, emaranhadas no que Bourdieu chama de "violência simbólica" (1999).

Muitas vezes o homem que participa nos afazeres de casa elabora um pacto de cumplicidade de silêncio com a esposa ou mãe que trabalha fora para preservar a imagem socialmente aceita dos dois. De qualquer jeito, para o homem que já está na idade de se sentir responsável pelo provimento de uma casa, é constituída uma ameaça à sua masculinidade por depender de uma provedora feminina. 
Com a esposa fora, trabalhando, e o homem desempregado ou com apenas trabalho precário, abre-se um espaço nebuloso sobre dois assuntos de construção da masculinidade a partir da casa: fidelidade e sustento. No caso dos homens, transgressões à fidelidade, historicamente, podem ter para eles um significado positivo, a favor da imagem da sua masculinidade. Falhas no sustento, no entanto, ferem a imagem da masculinidade do provedor. Em casas que têm um ganho seguro proveniente do trabalho da parceira e onde há uma aliança para a realização de serviços identificados como femininos, há uma desarticulação potencial da ideia dos homens que as suas casas estão 'sob controle' (Scott, 1990).

Um homem com trabalho precário, em casa, mesmo que não chegue ao extremo de dependência diante das esposas/companheiras, como descrito por Pedro Nascimento (2007), tem menor capacidade de significar a infidelidade como aspecto de reforço à masculinidade e, portanto, em seu próprio benefício. Aventurar-se neste campo pode significar perder a confiança da esposa e ser excluído do circuito doméstico dela. E para estes homens, depois dos 45 anos, torna-se cada vez mais difícil conseguir trabalho.

Segundo as mulheres que convivem com estes homens, há uma construção da imagem deles como "marginais por não poderem cantar de galo" (Woortmann, 1987; Neves, 1985) ou como "lerdos" (Salem, 1981). Comparados com os relatos sobre "o homem na família", bem discutidos por João de Pina Cabral (2003) para Portugal, os homens adultos nas camadas populares brasileiras manifestam vulnerabilidades mais acentuadas.

A vulnerabilidade masculina, ${ }^{6}$ empregada no título deste trabalho, é múltipla - social, individual e programática. Pode parecer um rótulo enganoso se adotarmos integralmente uma abordagem que identifica a forte presença de homens em bairros populares como uma estratégia de aproveitamento do trabalho da mulher pelo homem: enquanto elas trabalham, dando um 'duro' em casas alheias, eles ficam em casa, usufruindo dos resultados do trabalho delas.

Nesta interpretação, o homem passa de 'vulnerável' para 'explorador', expoente máximo do androcentrismo. Acontece que, simultaneamente, este androcentrismo está ameaçado pela dificuldade dos homens de passarem uma imagem da 'casa sob controle'. Certamente eles lutam para

6 O uso é particularmente útil pela importância do termo na literatura de saúde coletiva, seguindo José Ricardo Ayres $(1997,2001)$ e discutido por outros autores, incluindo Hermes Junior (2010). 
não perder a prerrogativa de 'controlador da casa', o que lhes confere a posição de pequenos patriarcas, insistindo que as suas casas estão sob controle, mascarando muito precariamente a pequena oferta de trabalho que o mercado lhes oferece e a fonte de onde vêm os recursos para sustentar a casa. O desemprego, ou o emprego muito precário, é, para eles, um atentado ao seu moral de provedor. É uma vulnerabilidade social entre as classes populares. Cada homem evita expor a sua vulnerabilidade individual. Torna-se uma condição de difícil apreensão e abordagem pelos serviços governamentais, sobretudo dos serviços de saúde que, programaticamente, visam a diminuir a vulnerabilidade da população, ao mesmo tempo que se dedicam, muitas vezes sem perceberem, a práticas que reforçam exclusões e vulnerabilidades sociais.

Há uma sintonia oculta entre a vulnerabilidade masculina programática e as vulnerabilidades sociais e individuais. No setor de segurança pública, Hermes Junior (2010) demonstra isso. Em Pernambuco, um amplo estudo da Universidade de São Paulo (USP), SOS Corpo e Fages (Núcleo de Família, Gênero e Sexualidade da UFPE), sobre as relações de gênero nos programas de saúde, revela as dimensões alcançadas por essa sintonia, chegando mesmo a elaborar uma brochura com recomendações para a Secretaria de Saúde estimular mais sensibilidade a estas questões entre os seus funcionários (Vilella \& Monteiro, 2005).

Em pesquisa sobre cuidados primários em quatro estados, Schraiber e colaboradores (2010) ampliam o escopo das evidências, e Couto e colaboradores (2010) levam ainda mais adiante o estudo, discriminando práticas que resultam na invisibilização dos homens nos programas de saúde.

Quando se conjugam estes estudos com a abordagem sobre saúde e gerações (Scott 2005, 2006), ainda se vislumbram as mudanças na vulnerabilidade ao longo do curso da vida. A situação nos dois extremos do ciclo evidencia estas transformações.

A vulnerabilidade masculina do jovem o afasta dos serviços de saúde. Ele passa por um período que poderia ser chamado de 'patofóbico', em que qualquer pequeno problema de saúde é interpretado como um atentado à sua masculinidade. $\mathrm{O}$ jovem prefere manter distância dos serviços de saúde, querendo mostrar um corpo 'sarado' capaz de servir-lhe de forma positiva no mercado de trabalho e no das conquistas amorosas (Uchoa, 1996; Cecchetto, 2004). Nesse período, os serviços de saúde costumam ser coniventes com esse desejo de manterem distantes, mesmo que seja por outras razões, mais associadas à expectativa de ameaças ao 
funcionamento administrativo e ao ambiente pacífico dos serviços. Esta prática cria uma distância profilática entre as camadas médias de profissionais e trabalhadores de saúde e as camadas pobres cuja vida cotidiana se percebe como pautada pela violência (Scott, 2005, 2006).

Nos serviços de saúde, são poucos os esforços para elaborar estratégias de envolvimento de jovens homens em trabalhos relacionados à saúde. A sua ânsia por trabalhar e produzir riqueza aponta caminhos variados de sucesso que alternam entre dois polos. De um lado, um trabalho pouco remunerado, que promove desgaste físico e que exige investimento em capacitações com limitados retornos de ganho e com uma precária segurança, e em uma união conjugal que pode oferecer ou não um apoio às suas estratégias de providenciar sustento. De outro lado, o envolvimento em atividades ilícitas que podem permitir uma promessa de enriquecimento rápido com uma submissão a uma rede hierarquizada que se caracteriza como não oferecendo nenhuma segurança. Tender para este polo aponta para uma sobrevida curta. A conjugalidade e colaboração no sustento costumam ceder espaço para a vivência de conquistas amorosas e uma exacerbação de uma masculinidade performática. O jovem é vulnerável, e os serviços de saúde pouco oferecem para lidar com esta vulnerabilidade.

A vulnerabilidade masculina entre idosos apresenta características muito diferentes. Com o marcado desgaste nas condições de saúde da população pobre, os homens se juntam às mulheres na vivência de patologias, sobretudo hipertensão e diabetes, o que os tornam candidatos à atenção dos serviços de saúde.

Para cada idoso a doença provoca medo. Individualmente, a 'patofobia', tão forte na juventude, retorna nas preocupações sobre o estado de saúde em decadência nesta faixa etária mais avançada. Os serviços de saúde, que manifestam receio da periculosidade que contatos com homens jovens e adultos possam representar, constroem uma imagem inversa, acolhendo os idosos masculinos justamente por causa da sua vulnerabilidade.

Por padecerem de algumas doenças, eles recebem um maior acolhimento nos serviços de saúde, chegando a desenvolver mais conhecimento e a obter mais cuidados sobre o estado de saúde, manifestando o que se poderia chamar de 'patofilia' (Scott, 2005, 2006). O idoso acolhido é um idoso inserido em programas de transferência de renda e previdência do governo, aposentado ou beneficiado, e as cifras sobre renda familiar identificam as famílias com idosos como as famílias com maior estabilidade e média de renda no Brasil (Camarano, 2004). 
Ou seja, enfraquecido pelo tempo de trabalho, pela própria idade e pelas patologias, o homem inverte pelo menos parcialmente a sua antiga estratégia de procurar status na relativamente inóspita rua, ficando em casa e sentindo-se com o direito de não andar tanto e de pedir que filhos e esposa cuidem dele e atendam às suas necessidades. Qualquer ameaça à ideia de perder o controle sobre a casa é amenizada, pelo menos enquanto ele não se tornar dependente econômica ou fisicamente de outros familiares. Afinal de contas, é ele que está assegurando a renda!

A esposa na rua (no caso de ele não ter recasado com uma esposa muito mais nova) já não causa a mesma incerteza sobre a potencial infidelidade que pode ter lhe preocupado antes. Aliás, faz algum tempo que ele percebe que as mulheres circulam muito e têm acesso a fontes de renda externas, seguras, construídas por trabalho, e relações clientelísticas com famílias em condições de lhes oferecer salários e presentes, então, entende que as mulheres circulam e isto pode ter implicações positivas para os recursos para a família.

As mulheres mais idosas, além de poder recorrer às redes clientelísticas, estabelecidas em trabalhos domésticos anteriores ou atuais, podem se envolver em grupos de terceira idade, identificados como comunitários e reconhecidos como contribuindo para melhorar os bairros onde residem. Esta nova circulação feminina é menos ameaçadora ao homem, por não envolver riscos tão diretos ao status de provedor. A vulnerabilidade maior decorre do potencial da sua própria debilitação física e da possível submissão a uma condição de dependente em casa dos próprios filhos, da mulher ou de outros. Assim enfrenta a ameaça da perda da sua condição de chefe, de pequeno patriarca. O fato de haver mais idosas que idosos na condição de dependente na casa de pessoas mais jovens dá uma indicação sobre quanto os homens se articulam para manter o status de "controlar uma casa", ficando como chefes, mesmo diante da precariedade econômica.

O sempre reconhecido crescimento de mulheres chefes de família entre os idosos revela os resultados de mortalidade diferencial. Evidencia, também, a valorização de uma autonomia decorrente de separações e viuvez. As mulheres receiam as implicações do recasamento, porque desconfiam dos resultados da inserção de um novo homem no meio da aliança doméstica e familiar que ela estabelece entre ela seus filhos, outros parentes e agregados próximos (Berquó, 1999; Camarano, 1999, 2004). Menos comentada é a facilidade com que as mulheres se inserem como avós, tias ou como outro tipo de dependentes na casa de outras pessoas. Esta opção é menos atraente para os homens, que a interpretam mais fortemente como 'vulnerabilidade'. 
Entre homens adultos, de 40 a 45 anos, não há uma grande aproximação aos serviços de saúde, que ainda os enxergam com a desconfiança semelhante à experimentada em relação aos homens jovens (Schraiber et al., 2010; Couto et al., 2010). Estes homens nem se sentem acolhidos nos serviços, nem têm nenhuma segurança assegurada por programas de previdência e transferência de renda, elaborando um discurso protetor do seu domínio de provedor, negando a relevância de bolsas de família ou relegando essas transferências às demandas femininas de consumo que eles julgam "menos importantes", como bem analisa Santos (2010).

Se um bom número de homens tem um emprego relativamente estável cujo rendimento pode ser usado na construção da simbologia de ser provedor familiar, há muitos que se encontram atingidos por desemprego persistente e, pior ainda, em processo de desgaste dos seus poderes físicos, importantes para a sua inserção no mercado de trabalho.

Verifica-se uma presença muito significativa de homens em bairros populares, com bem menos oportunidades de aproveitar a circulação entre bairros de níveis diferentes. Os recursos provenientes do trabalho doméstico das mulheres, muitas das quais estão trabalhando em outros bairros, podem ultrapassar em importância a renda dos homens, e os projetos de domínio masculino na esfera doméstica, elaborados na juventude, não se concretizam diante das dificuldades de efetivar o provimento da sua casa.

Esta 'vulnerabilidade' não tem manifestações muito claras na área de saúde, não sensibiliza outros setores públicos e mal mobiliza qualquer organização não governamental. É uma perda de controle masculino que não deixa de ser compensada por um ganho de controle feminino. Como consequência, não é visto facilmente como precisando ser remediado. Afinal, procurar resolver este problema de vulnerabilidade masculina poderia ser entendido como uma defesa da perpetuação do androcentrismo.

Em resumo, no curso da vida de homens jovens, adultos e idosos, as vulnerabilidades não deixam de existir, mas mudam de feições de acordo com os ciclos, cursos ou trajetórias de vida.

É importante lembrar que estes residentes de bairros populares são sujeitos a uma vulnerabilidade de classe, e que esta é uma vulnerabilidade exacerbada e camuflada em uma mobilidade entre bairros populares e bairros nobres que contribui para o empoderamento feminino construído nos padrões específicos de vivência familiar entre gerações e gênero em metrópoles. 


\section{Pontos para reflexão}

Fecha-se esta discussão recuperando algumas ideias apresentadas.

Primeiro: a ideia de curso de vida junto com ciclos domésticos diferenciados por gênero ajuda na compreensão de uma realidade de rápida reorganização e rearranjos familiares que ocorrem em toda a área urbana? Argumenta-se que sim, pois o trabalho de criação de filhos forma núcleos cuja estruturação obedece a processos domésticos que podem ser entendidos como ciclos e cursos vividos diferentemente por homens e mulheres. Os rearranjos produzem uma circulação de pessoas, que reafirma os processos domésticos, especialmente sensíveis à vivência de gênero no cotidiano.

Segundo: é útil entender a relação entre bairros nobres e bairros populares como uma relação permeada por circulação de mulheres, e, em menor escala, homens? A permeabilidade de estabelecimento de residência pode representar uma incorporação da mulher, de idade produtiva, dos bairros populares nas casas de moradores de bairros mais ricos, seja como esposas, companheiras ou, mesmo, empregadas.

Terceiro: os espaços de moradia populares, de jovens e de adultos em plena idade produtiva, podem ser vistos como relativamente masculinizados? Isto se dá quando se examina comparativamente a composição da população dos bairros. Ou seja, ao olhar os locais de residência e as faixas etárias, há um processo, costumeiramente invisibilizado, de masculinização relativa da pobreza na fase adulta (40-45 anos).

Quarto: os processos da queda de fecundidade e aumento da longevidade diferenciam a vida de pobres e ricos? De fato, apresentam efeitos muito mais marcantes sobre os moradores de bairros nobres, diminuindo a presença de pessoas na primeira infância e ampliando a presença dos mais idosos. Isto resulta na questão de o envelhecimento populacional ser mais premente para esta população, mas não retira a sua importância para quem mora em bairros populares.

Quinto: Sabe-se o suficiente sobre circulação e mobilidade intraurbana diferenciada por gênero? Evidentemente, não. Há uma necessidade de ampliar os estudos de caso aprofundados sobre as implicações da circulação de pessoas (e recursos) para a formação de redes de parentes, amigos e vizinhos que residem em casas e em bairros diferentes.

Sexto: A ideia de vulnerabilidade masculina é 'escorregadia', pois ora pode referir a questões de patologia, ora a questões de simbologia sobre as relações de gênero prevalecentes entre as classes populares. 
Os estudos da área da saúde fornecem um quadro de conceitos que permitem diferenciar, pelo menos analiticamente, vulnerabilidade social, individual e programática. Analisar as variações nas relações de gênero e na configuração específica de vulnerabilidades resulta na percepção de aproximações e distanciamentos entre os serviços oferecidos pelo Estado e pelo cotidiano de quem reside em bairros populares, ao se comparar com quem reside em bairros nobres. A agência masculina de procurar significar a vivência do espaço doméstico como 'sob controle' revela a persistência de uma cultura androcêntrica no meio de processos sociais que não favorecem a continuidade do controle dos homens sobre suas casas.

\section{Referências}

ARAÚJO, K. M. Família e Espaço Público: organização social e conflito na reprodução social de grupos pertencentes a camadas médias, 1984. Dissertação de Mestrado, Recife: Universidade Federal de Pernambuco.

ARIZPE, L. Culturas en Movimiento: interactividad cultural y procesos globales. México: Senado de la República, Unam y M.A. Porrúa, 2007.

ÁVILA, M. B. M. O Tempo de Trabalho das Empregadas Domésticas: tensóes entre dominação/exploração e resistência, 2009 Tese de Doutorado, Recife: Universidade Federal de Pernambuco.

AYRES, J. R. Vulnerabilidade e Aids: para uma resposta social à epidemia. Boletim Epidemiológico DST-AIDS, 15(3): 2-4, 1997.

AYRES, J. R. Sujeito, intersubjetividade e práticas de saúde. Ciência \& Saúde Coletiva, 6(1): 63-72, 2001.

BARROS, M. L. de. Autoridade e Afeto: avôs, filhos e netos na família brasileira. Rio de Janeiro: Zahar, 1987.

BERQUÓ, E. S. (Org.). Abep: primeira década, avanços lacunas, perspectivas. Belo Horizonte: Abep, 1988.

BERQUÓ, E. S. Considerações sobre o envelhecimento da população no Brasil. In: NERI, A. L. \& DEBERT, G. G. (Orgs.). Velhice e Sociedade. Campinas: Papirus, 1999. (Coleção Vivaidade).

BOURDIEU, P. A Dominação Masculina. Rio de Janeiro: Bertrand Brasil, 1999.

CAMARANO, A. A. Muito Além dos 60: os novos idosos brasileiros. Rio: Ipea, 1999.

CAMARANO, A. A. Mulher idosa: suporte familiar ou agente de mudança? In: ENCONTRO NACIONAL DE ESTUDOS POPULACIONAIS, 2004, Caxambu. Anais... Caxambu: Abep, 2004.

CECCHETTO, F. Violência e Estilos de Masculinidade. Rio de Janeiro: Editora FGV, 2004. 
CHAYANOV, A. V. The theory of peasant economy. In: THORNER, D.; KERBLAY, B. \& SMITH, R. E. F. (Eds.). A. V. Chayanov on the Theory of Peasant Economy. Homewood: American Economic Association, Richard Irwin, 1966.

COUTO, M. T. et al. O homem na atenção primária à saúde: discutindo (in)visibilidade a partir da perspectiva de gênero. Interface - Comunicação, Saúde, Educação, 14(33): 257-270, 2010. Disponível em: <www.scielo.br/pdf/icse/v14n33/a03v14n33.pdf>. Acesso em: 6 dez. 2011.

DALSGAARD, A. L.; FRANCH, M. \& SCOTT, P, Dominant ideas, uncertain lives: the meaning of youth in Recife. In: HANSEN, K. T. et al. (Eds.). Youth and the City in the Global South. Bloomington: Indiana University, 2008.

DEBERT, G. G. A Reinvenção da Velhice. São Paulo: Edusp, Fapesp, 1999.

FRANCH, M. Tempos, Contratempos e Passatempos: um estudo sobre práticas e sentidos de tempo entre jovens populares do Grande Recife, 2008. Tese de Doutorado, Rio de Janeiro: Programa de Pós-Graduação em Antropologia e Sociologia, Instituto de Filosofia e Ciências Sociais, Universidade Federal do Rio de Janeiro.

FORTES, M. Introduction. IN: GOODY, J. (Ed.). The Developmental Cycle of Domestic Groups. Cambridge: Cambridge University Press, 1958.

GOLDANI, A. M. As famílias no Brasil contemporâneo e o mito da desestruturação. Cadernos Pagu, 1: 67-110, 1993.

GOUGH, K. V. \& FRANCH, M. Spaces of the street: socio-spatial mobility and exclusion of youth in Recife. Children's Geographies, 3(2): 149-166, 2006.

HERMES JUNIOR, I. A vulnerabilidade social dos trabalhadores. Fórum Brasileiro de Segurança Pública, 8 dez. 2010. Disponível em: <www2.forumseguranca. org.br/node/24083>. Acesso em: 4 mar. 2011.

HITA, M. G. Pobreza, composición familiar y inclusión social: arreglo matriarcal en un Brasil negro. In: SEMINÁRIO INTERNACIONAL: POBREZA, EXCLUSIÓN Y DISCRIMINACIÓN ÉTNICO-RACIAL EN AMÉRICA LATINA Y EL CARIBE, 2006, Cali. Anais... Cali: Clacso-Crop, 2006.

INSTITUTO BRASILEIRO DE GEOGRAFIA E ESTATÍSTICA (IBGE). Manual do Recenseador. Rio de Janeiro: IBGE, 1999. Disponível em <www1.ibge.gov.br/home/ estatistica/populacao/censo2000/metodologia/anexos/coleta/anexo86.pdf > . (Versão preliminar disponível em: <http://biblioteca.ibge.gov.br/visualizacao/ instrumentos_de_coleta/doc0781.pdf $>$.

INSTITUTO BRASILEIRO DE GEOGRAFIA E ESTATÍSTICA (IBGE). Censo Demográfico 2000. Rio de Janeiro: IBGE, 2000. Disponível em: <www.ibge.gov.br/ censo $>$.

INSTITUTO BRASILEIRO DE GEOGRAFIA E ESTATÍSTICA (IBGE). Perfil dos Idosos Responsáveis pelos Domicilios no Brasil 2000. Rio de Janeiro: IBGE, 2002. (Série Estudos e Pesquisas, 9) 
JELIN, E. Las familias en América Latina. In: SALINAS, C. et al. (Orgs.). Familias. Santiago de Chile: Siglo XXI, Isis Internacional, 1994.

JOHNSON-HANKS, J. On the limits of life stages in Ethnography: toward a theory of vital conjunctures. American Anthropologist, 104(3): 865-880, 2002.

KIMMEL, M. A produção simultânea de masculinidades hegemônicas e subalternas. Horizontes Antropológicos: corpo, saúde e doença, 9, ano 4: 103-117, 1998.

LAGES, W. Uma Andorinha só Não Faz Verão: um estudo sobre a velhice feminina e a sociabilidade num bairro popular recifense, 2007. Dissertação do Mestrado, Recife: Universidade Federal de Pernambuco.

MARCELIN, L. H. A linguagem da casa entre os negros do Recôncavo Baiano. Mana, 5(2): 31-60, 1999.

MOTTA-MAUÉS, M. A. Na casa de mãe, na casa do pai: anotações (de uma antropóloga e avó) em torno da circulação de crianças. Revista de Antropologia, 47(2): 427-452, 2004.

MULLER, E. Transição é a Vida Inteira: uma etnografia sobre os sentidos e a assunção da adultez, 2008. Tese de Doutorado, Recife: Universidade Federal de Pernambuco.

NASCIMENTO, P. Antropologia, feminismo e masculinidades, ou o que os papudinhos de Camaragibe tem a ver com o debate sobre os homens no feminismo. In: BONETTI, A. \& FLEISCHER, S. (Orgs.). Entre Pesquisar e Militar: contribuições e limites dos trânsitos entre pesquisa e militâncias feministas. Brasília: Centro Feminista de Estudos e Assessoria, 2007.

NEVES, D. P. Nesse terreno galo não canta: estudo do caráter matrifocal de unidades familiares de baixa renda. Anuário Antropológico, 83: 199-221, 1985.

OBSERVATÓRIO PE. Microdados de Recife: censo demográfico 2000. Recife: Programa de Pós-Graduação em Geografia da UFPE, 2002.

ORTNER, S. B. Making Gender: the politics and erotics of culture. Boston: Beacon Press, 1996.

ORTNER, S. B. Poder e projeto: reflexões sobre agência. In: GROSSI, M. P.; ECKERT, C. \& FRY, P. H. (Orgs.). Conferências e Diálogos: saberes e práticas antropológicas. $25^{\mathrm{a}}$ Reunião Brasileira da Antropologia - Goiânia. Blumenau: Nova Letra, 2007.

PEIXOTO, C. E. (Org.). Família e Envelhecimento. Rio de Janeiro: Editora FGV, 2004.

PERES DA COSTA, M. L. B. M. Família de Pobre/Família de Rico: família de jovem/ família de velho, 1983. Dissertação de Mestrado em Antropologia, Recife: Universidade Federal de Pernambuco.

PINA CABRAL, J. de. O Homem na Família: cinco ensaios de antropologia. Lisboa: Imprensa de Ciências Sociais, 2003.

SALEM, T. Mulheres faveladas: com a venda nos olhos. In: FRANCHETTI, B.; CAVALCANTI, M. L. \& HEILBORN, M. L. (Orgs.). Perspectivas Antropológicas da Mulher. 1. ed. Rio de Janeiro: Zahar, 1981. 
SANTOS, G. M. N. C. dos. Ele Ainda Canta de Galo: etnografando homens pobres no domínio da casa, 2010. Dissertação de Mestrado, Recife: Universidade Federal de Pernambuco.

SCOTT, P. Migrações interregionais e estratégia doméstica. Relatório CNPQ. Recife, 1984.

SCOTT, P. Classe e discurso familiar sobre habitação e saúde. In: ENCONTRO ANUAL DE ANPOCS, 1989, Caxambu. Anais... Caxambu: Anpocs, 1989.

SCOTT, P. O homem na matrifocalidade: gênero, percepção e experiências do domínio doméstico. Cadernos de Pesquisa (Fundação Carlos Chagas), 73: 38-47, 1990.

SCOTT, P. Gênero, família e saúde. In: ENCONTRO DE CIÊNCIAS SOCIAIS DO NORTE NORDESTE, IV, 1991, Recife. Anais... Recife: Fundação Joaquim Nabuco, Massangana, 1991.

SCOTT, P. Família, gênero e saúde na Zona da Mata de Pernambuco. In: REUNIÃO BRASILEIRA DE ESTUDOS POPULACIONAIS, ABEP, XI, 1998, Caxambu. Disponível em: <www.abep.nepo.unicamp.br>. Acesso em: 14 ago. 2010.

SCOTT, P. Quase adulta, quase velha: por que antecipar as fases do ciclo vital. Interface: Comunicação, Saúde, Educação, 5(8): 61-72, 2001.

SCOTT, P. Envelhecimento e juventude no Japão e no Brasil: idosos, jovens e a problematização da saúde reprodutiva. In: MINAYO M. C. S. \& COIMBRA JR., C. A. (Orgs.). Antropologia, Saúde e Envelhecimento. Rio de Janeiro: Editora Fiocruz, 2002.

SCOTT, P. Gênero, família e comunidades: observações e aportes teóricos sobre o Programa saúde da Família. In: VILLELA, W. \& MONTEIRO, S. (Orgs.). Gênero e Saúde. Rio de Janeiro, Brasília: Abrasco, UNFPA, 2005.

SCOTT, P. Gerações, comunidades e o Programa Saúde da Família: reprodução, disciplina e a simplificação administrativa. In: BARROS, M. L. (Org.). Família e Gerações. Rio de Janeiro: Editora FGV, 2006.

SCOTT, P. Trocando a casa e a rua: idosos e a inversão da construção de gênero em camadas populares urbanas. In: SCOTT, P. \& QUADROS, M. (Orgs.). A Diversidade no Ibura: gênero, geração e saúde num bairro popular do Recife. Recife: Editora Universitária da UFPE, 2008.

SCOTT, P. \& FRANCH, M. Jovens, moradia e reprodução social: processos domésticos e espaciais na aquisição de habilidades e conhecimentos. Estudos de Sociologia, 7(1): 95-126, 2004.

SOUTO-MAIOR, H. Familias conviventes no Brasil e no Nordeste: uma análise comparativa dos Censos de 1970 e 1980. In: ENCONTRO ANUAL DA ANPOCS, XVI, 1992, Caxambu.

UCHOA, R. S. Gerações e saúde: um estudo de caso dos jovens. In: SCOTT, P. (Coord.). Saúde e Pobreza no Recife: poder, gênero e representações de doenças no bairro do Ibura. Recife: Nusp, Editora Universitária da UFPE, 1996.

VILlELA, W. \& MONTEIRO, S. (Orgs.). Gênero e Saúde: Programa Saúde da Familia em questão. Rio de Janeiro, Brasilia: Abrasco, Fundo de População das Nações Unidas, 2005.

WOORTMANN, K. A Familia das Mulheres. Rio de Janeiro, Brasilia: Tempo Brasileiro, CNPq, 1987. 


\title{
4
}

Reflexões sobre a Saúde dos Homens Jovens: uma articulação entre juventude, masculinidade e exclusão social

\author{
Marcos Nascimento, Márcio Segundo e Gary Barker
}

É crescente o interesse, por parte de organizações da sociedade civil, universidades e centros de pesquisa, agências de cooperação internacional e formuladores de políticas públicas, no tema homens e masculinidades a partir de um referencial de gênero (WHO, 2000; OPS, 2002; Nascimento, 2004; Barker, 2008). Os desafios enfrentados na esfera da saúde sexual e da saúde reprodutiva, Aids e violência de gênero propiciaram uma série de pesquisas e de ações programáticas por parte de organizações não governamentais e de grupos comunitários que podem contribuir para o desenho de políticas públicas voltadas para a população masculina.

Conferências como as de Cairo (1994) e de Pequim (1995) indicaram, em suas plataformas de ação, a necessidade de incluir os homens, adultos e jovens, nas ações voltadas à promoção da saúde sexual e reprodutiva.

O conceito de gênero - a construção social do que se entende por ser homem e por ser mulher - é uma ferramenta interessante para compreender o processo de socialização masculina. Esse processo de aprendizagem do que é ser homem ou mulher pode produzir/perpetuar/ desconstruir as desigualdades de gênero. Mas é preciso ter em mente que a dimensão de gênero interage com raça/etnia, classe social, orientação sexual, geração, estabelecendo diferentes perfis e tornando o cenário das relações de gênero cada vez mais complexo.

Para falar da diversidade de possibilidades de ser homem, o termo masculinidade, no singular, precisou ser revisitado. A concepção patriarcal de uma masculinidade atrelada a valores tradicionais não é a única possível 
e não representa os homens em sua totalidade. Outras possibilidades de ser homem passam a ser consideradas e incentivadas. Vozes masculinas mais participativas no que se referem a cuidados na esfera da saúde sexual e reprodutiva, mais engajadas no exercício da paternidade, que não usam e não aceitam o uso da violência para a resolução de conflitos podem nortear intervenções no campo da saúde e da educação, com vistas a promover a saúde e a equidade de gênero entre homens jovens (Barker et al., 2004; Barker, 2008).

Fala-se não mais de uma única forma de ser homem, mas de formas plurais e diversas - os homens e as masculinidades entram em cena (Connell, 1995; Nascimento, 2001; OPS, 2002; Nolasco, 1993). E é nesse cenário de trabalho com homens, em uma perspectiva de gênero e de promoção da saúde, com o referencial da pluralidade e da diversidade de suas experiências cotidianas, que este trabalho está centrado.

Tratando-se especificamente dos homens jovens, o Brasil, assim como outros países da região, assiste a um cenário complexo no que se refere à juventude de maneira geral, colocando-os em diferentes situações de vulnerabilidades, como apresentado a seguir.

\section{Homens jovens e saúde sexual e reprodutiva}

Um dos marcos importantes da Plataforma do Cairo (Conferência Internacional sobre População e Desenvolvimento, realizada no Cairo, em 1994) é a inclusão dos adolescentes e jovens do sexo masculino nas políticas voltadas para a saúde sexual e saúde reprodutiva.

Contudo, esta recomendação não está suficientemente expressa nas políticas de saúde sexual e saúde reprodutiva, o que traz alguns obstáculos para o acesso de adolescentes e jovens aos serviços de saúde.

Em pesquisa realizada pela Unesco (Castro, Abramovay \& Silva, 2004) com adolescentes e jovens escolarizados de ambos os sexos em todo o país, o serviço de saúde aparece em quarto lugar como um espaço confiável para obter informações sobre sexualidade, incluindo uso de métodos contraceptivos, prevenção de doenças sexualmente transmissíveis e Aids.

De maneira geral, os homens jovens pouco utilizam os serviços de saúde com o objetivo de cuidar de sua saúde sexual e reprodutiva. Este fato parece estar associado a uma ideia vigente de que homens não cuidam da própria saúde de maneira proativa e, em maior medida, no que se refere às questões de saúde sexual e reprodutiva (Promundo, 2005; Gomes, 2008). 
Os serviços de atenção à saúde sexual e reprodutiva partem de uma lógica de atendimento prioritário às mulheres. Esta realidade resulta em uma ausência de serviços específicos, especialmente na atenção básica, de atendimento a homens adolescentes e jovens (e também adultos), assim como práticas, condutas e ações voltadas para sua inclusão no atendimento relacionado à gravidez, à contracepção e a demais temas vinculados à saúde sexual e reprodutiva.

No que se refere aos homens adolescentes e jovens que fazem sexo com homens, a situação ainda é menos conhecida. Não se dispõe de informações nacionais sobre a vida sexual (e por que não dizer também reprodutiva) desse segmento da população, e é muito provável que estes jovens não levem aos serviços de saúde seus problemas e preocupações em torno da sexualidade, devido à carga de preconceito e discriminação que sofrem na sociedade (Brasil, 2008). Segundo estudos da Associação Brasileira Interdisciplinar de Aids - Abia (2002) -, os jovens gays muitas vezes não sabem como lidar com o desejo sexual por outro homem. Não sabem como pedir ajuda (e a quem), e isso atinge sua autoestima e autocuidado, deixando-os vulneráveis.

\section{Homens jovens e HIV/Aids}

A epidemia da Aids vem crescendo entre adolescentes e jovens e, dentre estes, notadamente entre as mulheres jovens. A prevalência da Aids entre adolescentes de 15 a 19 anos passou de 0,6\% até 1990 para $2,0 \%$ de 1991 a 2000 , e de $2,4 \%$ para $10,5 \%$ entre jovens de 10 a 24 anos, no mesmo período. O perfil da epidemia aponta desde o final dos anos 90 para o crescimento da infecção entre mulheres e, em particular, entre mulheres e homens das classes populares.

O uso do preservativo masculino nas relações sexuais aparece como uma das estratégias de prevenção das doenças sexualmente transmissíveis. No entanto, o acesso ao preservativo e a negociação do seu uso são pontos fundamentais para práticas de sexo seguro. Para tal, é necessária uma mudança de cultura em relação às dinâmicas das relações de gênero.

Uma pesquisa realizada pelo Instituto Promundo com 225 homens jovens (Promundo, 2002), em um bairro de periferia no Rio de Janeiro, mostrou que uma das maiores dificuldades dos rapazes era negociar o uso da camisinha com a parceira. Não se trata somente de ter ou não acesso à informação (ainda que a informação seja imprescindível). Valores como 
confiança, intimidade, comunicação entre os parceiros estão presentes nesse cenário das práticas sexuais e afetam o processo de negociação do preservativo.

\section{Homens jovens, acidentes e violências}

Segundo dados do Ministério da Saúde, as violências representam a terceira causa de morte da população em geral. Dados de 2006 mostram um total de 48.424 homicídios e 33.602 óbitos provocados por trânsito (Brasil, 2008).

Em relação aos homicídios, a maioria das vítimas da violência urbana (homicídios e mortes provocadas por acidentes de trânsito) são homens, jovens, negros, com pouca e nenhuma escolaridade e baixo nível socioeconômico (Brasil, 2008).

Quando se considera a distribuição das taxas de homicídio, por sexo e faixa etária, observa-se que a maior incidência ocorreu entre jovens e adultos jovens, dos 15 aos 39 anos, e que a fase crítica é dos 20 aos 24 anos de idade. A magnitude desses números explica a baixa na pirâmide populacional observada no último censo demográfico em relação à população masculina jovem, fenômeno típico de países em guerra (IBGE, 1999).

Em relação ao uso da violência em espaços domésticos, segundo pesquisa realizada pelos institutos Promundo e Noos (Acosta \& Barker, 2003) com 749 homens entre 15-59 anos, no Rio de Janeiro, 25,4\% admitiram já ter usado algum tipo de violência física contra uma parceira íntima. Na faixa etária de 20-24 anos, o índice sobe para quase $30 \%$, nos três meses anteriores à pesquisa.

A cultura masculina patriarcal tradicional, com ênfase na manutenção da assimetria de poder entre homens e mulheres, banaliza, naturaliza e legitima o uso da violência como uma forma de 'solução de conflitos', no espaço público ou privado. Cada vez mais campanhas educativas e programas voltados para a prevenção da violência entre jovens ganham espaço (Nascimento, 2001).

Um tema pouco abordado, nem por isso menos importante, é o suicídio entre jovens. As maiores taxas de suicídios encontram-se entre os homens, embora o maior número de tentativas estejam entre as mulheres. Segundo dados de 2006, houve 8.506 mortes por suicídio no país. Desses óbitos, 79\% foram de homens entre 20 e 39 anos de idade (Brasil, 2008). 
Os homens escolhem maneiras mais agressivas para as tentativas de suicídio, como o uso de armas de fogo, por exemplo. Já as mulheres utilizam substâncias como remédios, venenos e outras, o que possibilita tempo para ajuda. Trata-se de um tema que merece mais atenção, análise e investimento para desenhos de distintas abordagens que incluam tanto a prevenção como o acolhimento.

Podemos concluir que a articulação entre as diversas formas de violência (interpessoal, de gênero, homofobia, suicídio e os acidentes) e a construção das masculinidades é extremamente importante para um debate acerca da juventude. Não se trata de reduzir a masculinidade à violência, mas pensar de que maneira a socialização de meninos (e de meninas) e a falta de condições sociais de educação, saúde e exercício da cidadania contribuem para que a violência apareça como um repertório masculino cada vez mais comum e banalizado.

\section{Homens jovens e o mercado de trabalho}

O ingresso no mercado de trabalho formal representa um rito de passagem para rapazes das camadas populares. Conseguir o emprego de 'carteira assinada' é um sonho nem sempre alcançado (Novaes, 2006). Ser capaz de se manter e de sustentar a família é parte da construção do papel do homem provedor, homem responsável, homem de verdade, tornandose um importante pilar na construção da masculinidade dos rapazes (Nolasco, 1993; Barker, 2008).

Em estudo realizado pela Fundação Perseu Abramo em 2005, apenas $36 \%$ dos jovens entre 15 e 24 anos de idade possuíam emprego formal e, na média, demoravam 15 meses para conseguir o primeiro emprego ou uma nova ocupação nas regiões metropolitanas.

No que se refere à saúde do trabalhador adolescente e jovem, Barker (2004) aponta que há cerca de 219 mil acidentes de trabalho por ano no Brasil, referentes apenas aos dados de jovens inseridos no trabalho formal (regulado pelo Ministério do Trabalho e Emprego), não incluindo os dados daqueles jovens inseridos na economia informal.

\section{Homens jovens e educação}

Segundo dados de um estudo realizado pelo Fundo das Nações Unidas para a Infância (Unicef, 2002), 57\% dos jovens brasileiros de ambos 
os sexos (15-24 anos) não completaram o ensino fundamental. Para o Rio de Janeiro, esse percentual chega a 47,5\% (Fernandes, 2002).

Em termos de evasão escolar, uma pesquisa desenvolvida pela Coordenação de Estudos e Pesquisas sobre a Infância da Universidade Santa Úrsula (Cespi) e pelo Instituto Promundo, com 218 adolescentes e jovens (13-19 anos), oriundos de classe popular, mostra que 20,6\% das meninas, em comparação com $42 \%$ dos meninos, já passaram pelo menos um ano fora da escola, ou seja, o dobro de meninos em relação às meninas. Como a escola pode ser um espaço privilegiado para engajar os homens jovens no uso do sistema de saúde, essa evasão indica mais uma vulnerabilidade a que os homens adolescentes e jovens estão submetidos.

No caso de jovens oriundos de espaços populares, Souza (2003) chama a atenção para outro ponto em relação à evasão escolar: a falta de significado que a escola possui para eles, colocando a universidade como um 'sonho inatingível'. O trabalho informal e, muitas vezes, o narcotráfico passam a ser a 'opção' para jovens de camadas populares.

Se esses dados revelam um quadro problemático, é justamente no período da adolescência/juventude que há um grande potencial para mudanças e transformação pessoal (Pais, 2003; Velho, 2006).

Nessa fase da vida, os indivíduos estão iniciando suas vidas afetivas e sexuais e ingressando no mercado de trabalho (formal ou informal). E é justamente nesse período que os jovens começam a pensar em termos mais abstratos e mais a longo prazo. São capazes de distinguir as disparidades do mundo em que vivem - em termos de renda, de classe social, de gênero - e estabelecem critérios de comparação com a vida real (Barker, 2008).

Como se pode observar, as necessidades de saúde dos homens jovens se inserem num cenário extremamente complexo e desafiador. Os programas que procuram incluir os homens jovens na promoção de saúde precisam ter uma visão mais atenta sobre o binômio 'homens e saúde', procurando, por exemplo, questionar as normas sociais de gênero a que homens e mulheres estão expostos e como elas afetam a sua saúde (Barker et al., 2006). 


\section{Homens jovens no contexto dos serviços de saúde}

A saúde e o desenvolvimento dos adolescentes e jovens têm sido objeto de estudos, pesquisas e preocupação por parte de diferentes atores, como universidades, organizações da sociedade civil e gestores de políticas públicas.

Castro, Abramovay e Silva (2004) mostram que não podemos ver os jovens como um grupo homogêneo, mas sim na sua singularidade e diversidade. Dessa maneira, os homens adolescentes e jovens necessitam de atenção para as suas especificidades em termos de saúde e desenvolvimento e que se leve em consideração sua socialização de gênero.

Tendo como pontos de partida a revisão da literatura e a consulta a diversos programas em diferentes países, a World Health Organization (WHO, 2000) aponta uma série de considerações no que se refere à saúde dos homens adolescentes e jovens, destacando a necessidade de olhar para os rapazes não como delinquentes, violentos ou desinteressados. Ressalta a necessidade de olhá-los de maneira positiva e pensar como eles podem atuar como aliados no que se refere tanto a aspectos da própria saúde, por meio de comportamentos e atitudes relacionados ao autocuidado, como também à saúde das mulheres jovens.

Tradicionalmente, os serviços de saúde mantêm uma visão mais atenta para as questões das mulheres adolescentes e jovens, muitas vezes sem considerar as especificidades de gênero que os rapazes têm.

Pesquisas sugerem os seguintes pontos como relevantes para a saúde e o desenvolvimento dos homens jovens: acidentes de trânsito, violência, uso abusivo de drogas, saúde reprodutiva, saúde mental e estratégias de promoção de saúde (WHO, 2000; Elster \& Marcell, 2003; Brasil, 2008). Vale ressaltar que essas recomendações partem de uma visão holística sobre o assunto e que não se restringem apenas à saúde reprodutiva ou ao uso do preservativo como focos de atenção direcionados aos rapazes.

Um estudo qualitativo realizado pela Organização Pan-Americana da Saúde em nove países da América Latina (Opas, 2002), incluindo o Brasil, mostra que os homens adolescentes e jovens resistem a usar os serviços de saúde por não se sentirem à vontade. Eles têm vergonha e não contam com profissionais sensibilizados para as suas necessidades. 
Quando se fala em sensibilizar os rapazes para o autocuidado e para a busca por serviços de saúde, a família aparece como um aliado poderoso. Ela desempenha um papel importante na formulação das crenças, valores e conhecimentos sobre cuidado e saúde. Isso influencia sobremaneira a percepção da necessidade de ajuda e uso dos serviços de saúde por parte dos rapazes.

Se compararmos a forma como os meninos e as meninas são socializados em relação ao cuidado e à saúde, verifica-se que elas são mais propensas a usar serviços de saúde e a procurar mais ajuda do que os meninos. Isso acontece não somente como fruto da socialização, mas também pelo papel que os adultos desempenham nessas questões. Modelos de homens mais preocupados e sensíveis a questões de gênero podem ter um papel importante na construção de uma relação de autocuidado por parte dos homens (Elster \& Marcell, 2003).

A escola é outro aliado importante na luta pela saúde dos adolescentes e jovens. Disseminação de informações (adequadas e atrativas) e parcerias com unidades de saúde que atuam nas mesmas comunidades podem ajudar a facilitar o acesso dos jovens e adolescentes aos serviços de saúde. Além disso, a educação sexual pode ter um papel importante para a saúde sexual e reprodutiva dos jovens. No entanto, é preciso levar em consideração que, no Brasil (e em grande parte da região da América Latina), os meninos tendem a estar mais fora do sistema escolar, comparados às meninas. Este fato merece atenção e deve ser levado em conta no momento de desenhar as estratégias voltadas para a população masculina jovem (Souza, 2003; Barker, 2008).

Sabemos que a informação é fundamental para garantir a saúde dos jovens, mas, segundo alguns estudos, não é o suficiente para provocar a mudança de comportamentos de risco (Boler \& Aggleton, 2005). Daí a necessidade de avaliar o alcance e o impacto de campanhas e programas que se proponham à mudança de comportamento e atitudes dos jovens.

Portanto, o engajamento dos homens jovens nos serviços de saúde representa um desafio para os gestores e coordenadores de programas. Como fazer para que os rapazes reconheçam que precisam de apoio, procurem e reconheçam as unidades de saúde como local para obtê-lo e, ainda, que as unidades estejam preparadas para fornecer a informação, o atendimento, o aconselhamento de que esses jovens precisam?

Políticas e programas voltados para essa população mostram que os rapazes são mais propensos a usar serviços quando esses se apresentam de 
forma atrativa para eles; alguns reportam que ter profissionais do sexo masculino para atendê-los contribui para seu engajamento e sua adesão aos serviços de saúde. Outros, ainda, afirmam que nada disso é necessário, bastando que o profissional seja sensível às necessidades dos rapazes. Há ainda aqueles que apontam atividades extramuros (incluindo esportes, lazer e cultura), assim como a ação de promotores juvenis de saúde, como mecanismos para atrair e envolver os jovens nos serviços de saúde (WHO, 2000).

\section{Escutando os rapazes:}

\section{sentidos sobre os cuidados com a saúde}

Em 2005, o Instituto Promundo, em parceria com a Secretaria Municipal de Saúde do Rio de Janeiro, representada pelo Programa de Saúde do Adolescente (Prosad), e com o Núcleo de Estudos de Saúde do Adolescente da Universidade do Estado do Rio de Janeiro (Nesa/Uerj), e com apoio da Organização Pan-Americana da Saúde (Opas) e da Organização Mundial da Saúde (OMS), coordenou a implementação de uma pesquisa-ação intitulada Homens Jovens e Saúde.

Tratava-se de uma iniciativa-piloto de promoção de saúde entre homens jovens (15 a 24 anos de idade) e qualificação dos serviços em unidades básicas de saúde no município do Rio de Janeiro para o atendimento a essa população. Esta iniciativa se inseria em um debate mais amplo sobre homens e construção das masculinidades e suas relações com o campo da saúde, a partir de uma perspectiva de gênero e de uma abordagem integral da saúde.

Buscava-se compreender a demanda por serviços de saúde por parte de homens jovens de camadas populares na cidade do Rio de Janeiro: perceber as noções de cuidado e autocuidado que essa população possuía, a forma como essa noção era construída, quais eram os outros atores que estavam envolvidos nesse processo, a percepção dos rapazes sobre as próprias unidades de saúde e a identificação de possíveis barreiras que dificultavam o acesso a elas.

Procurava-se, também, perceber e qualificar a oferta de serviços de saúde voltada para essa população, com intuito de observar o processo de incorporação do segmento da população adolescente e jovem na rotina do serviço de saúde, as dificuldades e estratégias de enfrentamento existentes no cotidiano dessas unidades, a desconstrução de estereótipos 
em relação aos homens jovens por parte dos profissionais envolvidos e a articulação de parcerias com as comunidades em que estavam inseridos.

Este capítulo pretende centrar suas reflexões nos resultados da pesquisa qualitativa com homens jovens de camadas populares sobre suas percepções sobre masculinidade, saúde e cuidados com a saúde realizada durante o processo de planejamento da intervenção.

Foram realizados seis grupos focais com grupos de homens jovens (de 15 a 24 anos) de três diferentes localidades de baixa renda na cidade do Rio de Janeiro. Todos os participantes eram voluntários e os grupos foram realizados nas unidades básicas de saúde locais. Cada grupo focal foi facilitado por um homem, com intuito de que os participantes ficassem mais à vontade para falar sobre as questões envolvidas com o cuidado da saúde.

O objetivo dos grupos focais era compreender as percepções dos rapazes sobre saúde e cuidado, sexualidade, incluindo questões sobre a saúde sexual e reprodutiva, o acesso e as possíveis barreiras aos serviços de saúde, além de questões referentes à saúde no espaço escolar.

As vozes dos rapazes contribuíram para a elaboração tanto das ações em cada uma das unidades de saúde quanto de materiais socioeducativos.

Durante a realização dos grupos focais, abordaram-se os seguintes temas: normas de gênero, saúde e cuidado, sexualidade, uso do preservativo, paternidade, uso dos serviços de saúde e qualidade do atendimento.

\section{Normas sociais em torno da masculinidade e das relações de gênero}

Ao responderem à pergunta: o que significa ser homem?, os jovens evocavam a figura do homem provedor e responsável pelo sustento da família. A família era vista de maneira tradicional, ou seja, com papéis bem definidos, 'homem que trabalha' e 'mulher que cuida da casa' e que deve respeito ao homem. Chamavam a atenção os casos de ausência de referencial paterno (quase todos os participantes não conviviam com os pais). Interessante observar que, apesar de viverem em casas chefiadas por mulheres, a ideia de que esse lugar de sustento da casa e da família deveria ser ocupado por um homem era bastante presente. 


\section{Sexualidade e o uso do preservativo}

Os rapazes apresentavam um discurso bastante ambíguo em relação ao uso do preservativo. Em um primeiro momento, defendiam o seu uso por conta de um discurso incorporado da prevenção do HIV/Aids. O preservativo como método de contracepção foi muito pouco citado. Os jovens também diziam que o preservativo incomodava e que não gostavam de usá-lo. Relataram inquietações sobre o quanto o uso do preservativo diminuiria o prazer da parceira e as dificuldades no processo de negociação do seu uso.

Esse tema merece uma reflexão mais aprofundada. Os rapazes, muitas vezes, são vistos como aqueles que têm uma sexualidade 'incontrolável' e que necessitam de informação e de disponibilização de preservativos. No entanto, ainda que o uso do preservativo esteja presente no chamado 'discurso da prevenção', esse discurso se esvazia no momento da negociação. Não é apenas necessário saber da importância do uso do preservativo ou poder 'dar uma aula' sobre como se pode infectar pelo HIV ou como armazenar ou usar o preservativo. Trata-se, portanto, da construção de uma habilidade de comunicação entre os parceiros e que deve envolver respeito, diálogo e confiança de ambas as partes.

Segundo a visão dos rapazes, os homens sentem mais desejo sexual do que as mulheres e por isso precisam de mais sexo e de mais parceiras. Em sua visão, os homens 'vão à caça', ao passo que as mulheres são mais 'passivas'. As relações sexuais são baseadas na heteronormatividade, não demonstrando qualquer possibilidade do exercício de uma sexualidade que não seja a heterossexual para os homens.

Alguns dos rapazes já eram pais e, segundo o discurso apresentado, 'não sabiam como deixaram isso acontecer'. O universo da reprodução era totalmente distante de suas preocupações. A reprodução entre adolescentes e jovens ainda é pautada em uma lógica da preocupação e responsabilidade femininas. Embora, gradativamente, aumente o debate em torno da paternidade adolescente (Lyra, 1998).

\section{Saúde em geral}

É preciso cuidado para não restringir as necessidades de saúde dos rapazes apenas ao preservativo ou à prevenção da Aids. A maioria dos programas voltados para os jovens tem foco nessas questões. Embora sejam importantes, há outras demandas que também merecem atenção e podem 
servir como porta de entrada para questões mais delicadas e íntimas como as questões de saúde sexual e reprodutiva.

A saúde bucal, problemas de acne ou referentes à nutrição e que estão ligadas à aparência física foram mencionados por quase todos os participantes e podem representar oportunidades para que os rapazes frequentem mais assiduamente as unidades de saúde.

Porque tem certos homens que não estão nem aí e não ligam para nada. Tipo de se colocar uma vaidade. Tem homem que não tá nem aí para nada, fica sujão, babão, cabeludão. Também na área da saúde não quer se tratar é meio parecido, né... (rapaz, 16 anos)

\section{Cuidado}

As noções de cuidado são aprendidas e encontram, na figura da mãe, a 'embaixadora do cuidado'. Grande parte das vezes era com a mãe (ou com outra figura feminina) que o rapaz ia ao médico ou ao posto de saúde. "Por mais machão que o cara seja, vai procurar sempre a mãe... machucou o dedo e parece que o mundo vai acabar" (rapaz, 18 anos).

\section{Sexo do profissional de saúde}

Um item em que não houve consenso foi o sexo do profissional que vai atender os rapazes. Para alguns, o fato de ser outro homem trazia uma identificação que poderia auxiliar tanto na condução de atividades de promoção da saúde quanto na adesão dos rapazes aos serviços. Para outros, o importante era que esse profissional fosse sensível às suas necessidades.

Eu acho que tem um pouco de diferença porque quando você vai com um médico que é homem, tipo o cara é homem e tu também já conversa... já quando é mulher você fica meio assim de fazer umas perguntas. (rapaz, 20 anos)

Tem que ser médico profissional para atender... importante é ser atendido, por homem, mulher ou homossexual. O que importa é que seja médico e vai conversar contigo numa boa. (rapaz, 18 anos)

O importante é ser bem atendido... o que importa é que a gente esteja sendo atendido por um médico mesmo. (rapaz, 18 anos) 


\section{O posto de saúde}

Os rapazes manifestaram um certo estranhamento pelo fato de o posto de saúde ser um lugar 'repleto de mulheres', uma ausência de referências a coisas do 'mundo masculino'. Como diziam os rapazes:

Eu mesmo, quando vou ao posto de saúde, não que eu me sinto envergonhado porque eu já tenho esclarecimento pra não ficar assim, mas fica estranho. Você vê um montão de mulher, sabe? A impressão é que você está num espaço que não é seu. (rapaz, 17 anos)

O posto é um lugar que só tem peito e barriga [se referindo aos cartazes no posto sobre amamentação e gravidez]. Nem parece que é coisa pra homem. (rapaz, 18 anos)

No entanto, os rapazes destacaram a importância de ter um espaço para conversar e trocar ideias. O espaço físico da unidade de saúde, a qualidade do atendimento, a relação com o/a profissional e as atividades de promoção da saúde apareceram como elementos atrativos para o uso do posto de saúde.

A doutora era simpática, me dava atenção e era paciente. O único defeito é que aqui é demorado pra caramba. (rapaz, 17 anos)

Eu gostei de ter tido a palestra e conhecer, legal, de se juntar aqui com os moleques para conversar e tal... esse bagulho aqui eu gostei, da gente estar conversando assim. (rapaz, 20 anos)

$E u$, particularmente, geralmente eu sempre tô perguntando a respeito das coisas. Inclusive até a respeito de (...) alguns problemas que eu tenho que consertar, como coluna e essas coisas todas pra no futuro conseguir carreira militar... Sempre a doutora tá falando e me dando algumas observações também. (...) A geladeira lá de casa, a hora que tu chega lá, olha lá um monte de observações só minhas. Não come sal, não pode fazer isso e não pode fazer aquilo. Sempre a doutora mesmo escreve e me dá. Eu entrego pra minha mãe e ela bota lá na porta da geladeira. (rapaz, 17 anos)

Isso aí me animou bastante [prática educativa] correr atrás, procurar me informar do meu corpo. Aprender a me prevenir que eu não sabia e hoje eu sei graças a $X$ e a todos os assistentes aqui do posto. Isso foi muito bom pra mim. (rapaz, 19 anos) 
Um tema recorrente na fala dos rapazes era a circulação restrita nos locais onde residiam. Na sua maioria, eram moradores de diferentes favelas cariocas ou 'jovens de comunidade', como se apresentavam. Em várias delas, dominadas pelo narcotráfico, a mobilidade dos jovens era dificultada, já que eram impedidos de cruzar determinados territórios. Além disso, em algumas delas, o posto de saúde local ficava em área controlada por grupos rivais das áreas onde viviam. Isso impedia o acesso dos jovens ao posto de saúde, fazendo com que eles buscassem hospitais e unidades de saúde fora de seus locais de moradia, dificultando mais ainda o acesso aos serviços de saúde.

\section{Doenças Sexualmente Transmissíveis (DST)}

As DST aparecem como um tema importante na atividade sexual dos homens jovens. Quando eles contraem alguma infecção dessa natureza, por vergonha da família, por falta de informação adequada ou serviços adequados, acabam por recorrer a 'soluções caseiras', geralmente orientadas por colegas.

Depois deu uma coceira desgraçada na gente, fiquei uma semana com aquela coceira, lavava toda hora, jogava álcool... a maior loucura... saía um bagulho branco do pênis. Tomava banho, botava álcool e mercúrio com iodo... porque tinha uns cortes em volta... queimava pra caramba... não fui nem ao hospital. Nem falei com a minha mãe, minha mãe fala pra caramba. Curei assim mesmo, com mercúrio, álcool e iodo. (rapaz, 20 anos)

\section{À guisa de conclusão}

Como se pode observar, a realidade que envolve os homens jovens de camadas populares é bastante complexa. Como entender o binômio homens/saúde a partir dessa complexidade? Esse é um desafio importante na busca por alternativas de engajamento dos homens jovens em ações de promoção da saúde.

Práticas vinculadas a um padrão cultural tradicional afetam sua busca por serviços de saúde. Compreender as normas sociais de gênero que favorecem a construção desses padrões é fundamental para realizar ações educativas e de acolhimento no âmbito da saúde que possibilitem o questionamento e a construção de outras formas de exercício da masculinidade dos homens jovens. 
A visão do homem como provedor ou sexualmente 'incontrolável', ou como violento, coloca o indivíduo do sexo masculino em diversas situações de vulnerabilidade. Ter modelos masculinos mais comprometidos com a igualdade entre os sexos, mais participativos nas questões de saúde sexual e saúde reprodutiva e no exercício da paternidade, e que não acreditam no uso da violência como forma de solução de conflitos é um fator importante na construção de novos repertórios para esses jovens.

Questões estruturais que funcionam como barreiras para a procura pelos serviços de saúde merecem particular atenção. A violência urbana a que os jovens moradores de favelas estão expostos é um tema particularmente importante. Homens jovens de periferia, negros e com menos anos de escolaridade constituem o grupo mais vulnerável às questões de violência, particularmente o homicídio. O cerceamento de sua circulação por conta da presença de grupos rivais no controle do narcotráfico nos espaços em que vivem agrega mais uma dificuldade ao acesso aos serviços de saúde, como foi visto nos depoimentos dos rapazes.

Em relação à sexualidade, nota-se a aquisição de uma gama de informações sobre HIV/Aids, DST e uso do preservativo. No entanto, nem sempre a prática está alinhada ao discurso dos rapazes. A necessidade de comunicação entre parceiros para a negociação do uso do preservativo é condição fundamental para a prática do sexo seguro. Relações de gênero pautadas pela desigualdade ou pela falta de habilidades de comunicação frequentemente presentes no período de iniciação sexual precisam ser trabalhadas em programas que atendam o público jovem (Pulerwitz et al., 2007).

Os homens não são iguais. Tratar questões relacionadas à orientação sexual se torna fundamental. Não se pode assumir que todo e qualquer jovem que chegue ao posto de saúde é heterossexual. Trabalhar a heteronormatividade com os profissionais de saúde é um passo importante na construção de agendas públicas de saúde mais inclusivas.

A construção de uma cultura masculina do cuidado (de si e do outro) representa outro desafio importante. No relato dos rapazes, atividades educativas em grupo parecem favorecer que o ambiente do posto seja percebido como um espaço de saúde e não somente de doença. Da mesma forma que parcerias entre escolas e outras instâncias comunitárias, na formulação de atividades extramuros, podem contribuir na construção dessa cultura do cuidado. 
É necessário criar, nos postos de saúde, ambientes amigáveis para os homens jovens. Quando um jovem diz que o posto é um lugar de 'peito e barriga' ele sinaliza a ausência de referenciais masculinos na produção de materiais educativos (cartazes, folhetos etc.). Trata-se, portanto, de rever se os homens não vão ao posto de saúde ou em que medida a organização dos próprios serviços afasta os homens. Muitos homens ainda pensam que saúde é 'coisa de mulher'. E, mais ainda, nos assuntos relacionados à reprodução. É necessário criar condições para que a atenção à saúde seja atrativa para esse segmento da população.

E, finalmente, deve-se partir de uma visão holística de saúde e desenvolvimento dos homens jovens para se constituir uma agenda de promoção, acolhimento e prevenção em saúde que seja inclusiva, que perceba a complexidade dos homens jovens e que estabeleça mecanismos eficazes de inclusão do tema 'homens e masculinidades' na elaboração de agenda pública de saúde.

\section{Referências}

ACOSTA, F. \& BARKER, G. Homens, Violência de Gênero e Saúde Sexual e Reprodutiva: um estudo sobre homens no Rio de Janeiro. Rio de Janeiro: Instituto Noos, Promundo, 2003.

ASSOCIAÇÃO BRASILEIRA INTERDISCIPLINAR DE AIDS (ABIA). Ditos e Ritos dos Jovens Gays: projeto juventude e diversidade sexual. Rio de Janeiro: Abia, 2002 .

BARKER, G. Homens na Linha de Fogo: juventude, masculinidade e exclusão social. Rio de Janeiro: 7Letras, 2008.

BARKER, G. et al. How do We Know if Men Have Changed? Promoting and measuring attitude change with young men: lessons from Program $H$ in Latin America. Oxford: Oxfam GB, 2004.

BARKER, S. L. Juventude e trabalho. In: SEMINÁRIO NACIONAL HOMENS JOVENS E EQUIDADE DE GÊNERO: PARTICIPAÇÃO JUVENIL, PROGRAMAS E POLÍTICAS PÚBLICAS, 2004, Brasília.

BOLER, T. \& AGGLETON, P. Life Skills Education for HIV Prevention: a critical analysis. London: Save the Children and Action Aid International, 2005.

BRASIL. Ministério da Saúde. Prevenção da Violência e Cultura de Paz. Brasília: Opas, 2008. (Painel de Indicadores do SUS n. 5)

CASTRO, M.; ABRAMOVAY, M. \& SILVA, L. Juventudes e Sexualidade. Brasília: Unesco, 2004. 
CENTRO DE ESTUDOS E PESQUISAS SOBRE A INFÂNCIA/UNIVERSIDADE SANTA ÚRSULA (CESPI/USU) \& PROMUNDO. Children, Youth and their Developmental Supports: strengthening family and community supports for children and youth in Rio de Janeiro - initial results 2000-2001. Rio de Janeiro: Cespi, Promundo, 2001.

CONNELL, R. Masculinities. Berkeley: University of California Press, 1995.

ELSTER, A. \& MARCELL, A. Health care of adolescent males: overview, rationale, and recommendations. Adolescent Medicine: state of art reviews, 14(3): 525 540, 2003.

FERNANDES, R. Educação de Jovens em Situação de Risco: dados do problema e ações da sociedade. Rio de Janeiro: Viva Rio, 2002. (Mimeo.)

FUNDAÇÃO INSTITUTO BRASILEIRO DE GEOGRAFIA E ESTATÍSTICA (FIBGE). Mortes Violentas: um panorama dos homicídios no Brasil. Rio de Janeiro: FIBGE, 1999.

GOMES, R. Sexualidade Masculina, Gênero e Saúde. Rio de Janeiro: Editora Fiocruz, 2008.

LYRA, J. Paternidade adolescente: da investigação à intervenção. In: ARILHA, M.; UNBEHAUM, S. \& MEDRADO, B. (Orgs.). Homens e Masculinidades: outras palavras. São Paulo: Ecos, Editora 34, 1998.

NASCIMENTO, M. Desaprendendo o Silêncio: uma experiência de trabalho com homens autores de violência contra a mulher, 2001. Dissertação de Mestrado, Rio de Janeiro: Instituto de Medicina Social, Universidade do Estado do Rio de Janeiro.

NASCIMENTO, M. (Re)pensando as 'masculinidades adolescentes': homens jovens, gênero e saúde. In: UZIEL, A. P.; RIOS, L. F. \& PARKER, R. G. (Orgs.) Construções da Sexualidade: gênero, identidade e comportamento em tempos de Aids. Rio de Janeiro: Pallas, 2004.

NOLASCO, S. O Mito da Masculinidade. Rio de Janeiro: Rocco, 1993.

NOVAES. R. Os jovens de hoje: contextos, diferenças e trajetórias. In: ALMEIDA, M. I. M. \& EUGENIO, F. (Orgs.). Culturas Juvenis: novos mapas do afeto. Rio de Janeiro: Zahar, 2006.

ORGANIZACIÓN PANAMERICANA DE LA SALUD (OPS). Hacerse Hombres: la construcción de la masculinidad en los adolescentes y sus riesgos. Washington: OPS, 2002.

PAIS, J. M. Culturas Juvenis. Lisboa: Imprensa Nacional, Casa da Moeda, 2003.

PULERWITZ, J. et al. Promovendo Normas e Comportamentos Equitativos de Gênero entre Homens Jovens como Estratégia de Prevenção do HIV/Aids. Washington: Population Council, 2007. 
PROMUNDO. Projeto de Jovem para Jovem: engajando homens jovens na prevenção de violência e na saúde sexual e reprodutiva no Rio de Janeiro. Rio de Janeiro: Promundo, 2002.

PROMUNDO. Homens Jovens e Saúde: promoção de saúde e qualificação dos serviços para a população masculina jovem. Relatório de pesquisa. Rio de Janeiro: Promundo, 2005. (Mimeo.)

SOUZA, J. de. Por Que Uns e Não Outros? Caminhada de jovens pobres para a universidade. Rio de Janeiro: Sette Letras, 2003.

VELHO, G. Juventudes, projetos e trajetórias na sociedade contemporânea. In: ALMEIDA, M. I. M. \& EUGENIO, F. (Orgs.). Culturas Juvenis: novos mapas do afeto. Rio de Janeiro: Zahar, 2006.

WORLD HEALTH ORGANIZATION (WHO). What about Boys? A literature review on the health and development of adolescent boys. Genève: WHO, 2000. 


\section{Discriminação, Cor/Raça e Masculinidade no Âmbito da Saúde: contribuições da pesquisa social}

Simone Monteiro e Fátima Cecchetto

Reflete-se, aqui, sobre situações de discriminação associadas à cor/ raça no cenário nacional, tendo como foco a população masculina jovem, visando a fomentar uma análise sobre as implicações das expressões de discriminação no âmbito dos agravos à saúde nesse segmento social.

A partir de uma introdução sobre os desafios metodológicos das investigações sobre discriminação no campo da saúde, assinalados na literatura internacional e nacional, priorizam-se dois eixos de análise. No primeiro, abordam-se aspectos da discriminação racial no contexto brasileiro com base em estudos socioantropológicos e etnográficos, seguido de uma discussão sobre as configurações da discriminação que envolvem homens jovens, classificados como negros/pretos.

O segundo eixo trata das conexões entre as manifestações de discriminação racial, situações de violência e estilos de masculinidade e seus reflexos nos dados de morbimortalidade masculina. $O$ percurso analítico, de caráter exploratório, tem o propósito de lançar luzes sobre as pesquisas e as políticas de saúde pública voltadas para a população masculina no país.

Em estudos internacionais, principalmente norteamericanos, temse analisado a relevância das diferentes formas de discriminação na produção das desigualdades sociais e em saúde (Stuber, Meyer \& Link, 2008; Parker \& Aggleton, 2003; Krieger, 2003). A partir dessas pesquisas, depreende-se que as diversas expressões de discriminação podem alterar negativamente as condições e a qualidade de vida humana e, desse modo, a saúde das pessoas e das coletividades. Isto significa dizer que certas 
manifestações discriminatórias podem acarretar danos psicológicos, alterações de comportamento, passando por exclusão social, incapacidades no trabalho e obstáculos nas interações cotidianas, bem como culminar em violência e morte. Destacam-se, portanto, a seriedade e as consequências de formas graves de discriminação, por seu caráter irreparável de negação dos direitos, que constituem fato preocupante e com implicações humanas e sociais, incluindo os agravos à saúde.

Nas reflexões sobre os efeitos da discriminação, encontram-se, com frequência, análises sobre os desafios teóricos e metodológicos das pesquisas acerca desse tema. Parte dos questionamentos relaciona-se ao fato de as expressões de discriminação variarem segundo as situações da vida real, os atores envolvidos e o momento sócio-histórico.

Por serem decorrentes das interações sociais, as formas de discriminação são contextuais. Resultam, portanto, da interdependência de múltiplos fatores associados ao contexto, às características das pessoas ou grupos (em relação à inserção social, aos papéis de gênero, à diversidade sexual, à cor/raça, dentre outros aspectos).

Desse ponto de vista, as análises generalizadas sobre a discriminação e suas consequências para os indivíduos e grupos sociais tendem a comprometer a validade do estudo. Faz-se necessário, portanto, explicitar os procedimentos metodológicos empregados no estudo de uma determinada dimensão da discriminação, indicando de que modo os demais marcadores sociais envolvidos naquele contexto específico foram contemplados na investigação.

Devah Pager (2006) examina os limites e potencialidades dos métodos empregados nas pesquisas sobre discriminação racial, tendo por base a literatura norteamericana sobre o assunto. Para tanto, a autora detalha de que modo os usos dos estudos de percepção, de sondagem de atitudes, das análises estatísticas e dos experimentos de laboratório e de campo resultam em análises consistentes ou não sobre o fenômeno.

Dentro de um eixo complementar, Williams, Neighbors e Jackson (2003) analisaram as evidências das associações entre a percepção da discriminação étnico-racial e saúde em estudos de base populacional, publicados entre 1998 e 2003. Os autores constataram a falta de consenso na literatura sobre a melhor forma de medir a exposição ao racismo, a importância da diferenciação entre as experiências recentes e cumulativas, as contribuições dos estudos sobre estresse para se investigar a discriminação, entre outros aspectos. 
Em direção semelhante, Nancy Krieger (2003) afirma que as consequências do racismo para a saúde da população são conhecidas, mas pouco investigadas. A autora alerta que as 'expressões biológicas das relações raciais' referem-se às alterações na constituição biológica dos indivíduos, causadas pela exposição (física e psicológica) a situações de racismo. Tal fenômeno não deve ser confundido com a 'racialização das expressões biológicas', que, de forma equivocada, relaciona traços, biológicos arbitrários a marcadores inatos associados a diferenças raciais.

Outros autores assinalam que os procedimentos metodológicos sobre as relações entre racismo e saúde devem considerar as contribuições das ciências sociais (Harell \& Hall, 2003). Nesse particular, compreende-se que as abordagens quantitativas podem ser articuladas aos estudos qualitativos, capazes de colaborar na elucidação das formações subjetivas decorrentes dos processos discriminatórios.

No que diz respeito à realidade nacional, há trabalhos sobre a percepção da população sobre o racismo no país, mas os estudos acerca das consequências da discriminação racial nos agravos à saúde ainda são escassos. Cabe ressaltar, todavia, que, nos últimos anos, a temática das relações entre cor/raça e saúde ganhou visibilidade e está sendo incorporada por pesquisadores da área da saúde coletiva, como indicam os trabalhos de Claudia Travassos e David Williams (2004), Naomar Almeida-Filho e colaboradores (2004), Simone Monteiro (2004), José Laguardia (2004), Luis Eduardo Batista (2005), Dora Chor e colaboradores (2004), Marcos Maio e Simone Monteiro (2005), Maria do Carmo Leal, Silvana da Gama e Cynthia da Cunha (2005), Fernanda Lopes, Cassia Buchalla e José Ricardo Ayres (2007). Embora tratem de temas variados - que incluem relações entre cor/raça, agravos associados à assistência pré-natal e agravos como depressão, obesidade, Aids, entre outros -, parte dos trabalhos assinala os desafios metodológicos dessa temática. São feitas indagações acerca das implicações das variações dos métodos e termos de classificação da cor/ raça e do uso da variável raça nos estudos em saúde. No campo das políticas públicas em saúde, igualmente o tema tem tido relevo por meio da proposição de um campo de estudo e intervenção voltado para a saúde da população negra (Maio \& Monteiro, 2005; Heringer, 2002).

As situações de discriminação de gênero também integram um eixo relevante nas discussões sobre as desigualdades em saúde, a despeito dos avanços e conquistas promovidos pelo movimento feminista. As repercussões das relações hierárquicas de gênero têm sido consideradas 
nas interpretações de agravos como o aumento de transmissões de HIV nas relações heterossexuais e entre mulheres, particularmente nos contextos de desigualdade socioeconômica e exclusão social (Guerreiro, Ayres \& Hearst, 2002; Greig et al., 2008; Monteiro, 2009).

Entretanto, uma revisão preliminar revela que os estudos sobre a interdependência entre gênero e demais marcadores sociais nos estudos sobre discriminação são mais limitados.

Cabe citar o trabalho pioneiro de Verena Stolcke (1991) sobre o modo como a diferença racial se constrói através do gênero e como a classe é moldada por gênero e cor/raça. Tal recorte estimula análises sobre a articulação de múltiplos sistemas de subordinação, bem como uma discussão acerca da tendência à naturalização das desigualdades na sociedade de classes. Crenshaw (2002), em outro contexto de pesquisa, demonstrou que frequentemente o racismo, a dominação masculina e a pobreza se cruzam, estruturando as posições relativas dos indivíduos, segundo o gênero.

Diante do exposto, compreende-se que a perspectiva da interseccionalidade pode orientar as reflexões sobre os diversos arranjos através dos quais as formas específicas de discriminação se manifestam. Em trabalho anterior (Cecchetto \& Monteiro, 2006), tal perspectiva foi adotada a partir da análise de experiências de discriminação de jovens das camadas populares do Rio de Janeiro, segundo o recorte de gênero, cor e classe. Interessa destacar que o olhar etnográfico permitiu identificar aspectos importantes sobre as dinâmicas específicas de discriminação social e racial vivenciadas por homens e mulheres jovens das camadas populares, moradores da região metropolitana do Rio de Janeiro.

Diante do vasto potencial de análise das implicações das diferentes formas de discriminação, pretende-se apresentar uma discussão sobre a discriminação racial interligada ao gênero masculino e à classe social e o seu crescente impacto no âmbito da saúde coletiva. Como assinalado, este enfoque orienta-se pelo pressuposto segundo o qual o exame das expressões de discriminação na realidade brasileira precisa considerar como os demais marcadores da diferença ou princípios classificatórios, como classe social, gênero e geração, operam articulados à cor/raça do grupo social e ao contexto pesquisado. Optou-se por destacar certas singularidades das relações raciais no país a partir de estudos no campo das ciências sociais. 


\section{Discriminação racial no contexto brasileiro}

$\mathrm{Na}$ linguagem cotidiana, na imprensa e mesmo na literatura sobre relações raciais, a ideia de discriminação, além de ser ampla, corresponde, muitas vezes, à noção de preconceito. De maneira simplificada, pode-se dizer que o preconceito seria o modo de ver certas pessoas ou grupos raciais/étnicos, ou seja, um sistema de atitudes e de disposições interiores, ao passo que a discriminação seria a manifestação concreta desse pensamento.

Segundo Maria Beatriz Rodrigues (2007: 56), a discriminação diz respeito a um "tratamento desigual dirigido a indivíduos ou grupos" por integrarem "categorias específicas" que não tem uma "justificativa plausível ou consenso social". A autora argumenta que as expressões de discriminação são dinâmicas pelo fato de serem produzidas a partir de efeitos sociais, apresentando, portanto, variações ao longo do tempo. $\mathrm{Na}$ mesma linha, a discriminação racial consiste no tratamento diferenciado de pessoas baseado na cor e na ideia de 'raça', podendo tal comportamento promover segregação e desigualdade social (Jaccoud \& Beghin, 2002; Guimarães, 2004).

Uma das mais importantes contribuições para o entendimento das formas de discriminação racial na sociedade brasileira foram os clássicos estudos de Oracy Nogueira (1998). Suas análises foram fundamentais para compreender a natureza da discriminação racial articulada ao sistema de classificação de cor no nosso país.

Com base em uma perspectiva comparativa entre os Estados Unidos e o Brasil, o autor argumenta, que no contexto nacional predomina o preconceito de "marca", relacionado à aparência, ao passo que, na sociedade norteamericana, o preconceito está relacionado à ascendência ou à origem. Dito de outro modo, no cenário nacional seriam as marcas fenotípicas - como o tom da pele, tipo de cabelo, formato dos lábios e do nariz, sobretudo quando elas se aproximam mais da tonalidade escura da pele - que mobilizariam o preconceito.

Além disso, Oracy Nogueira demonstrou como a experiência da discriminação por cor na sociedade nacional era matizada por outros aspectos extrarraciais como instrução, polidez, elegância, entre outros.

Com base nessa argumentação, tem sido possível afirmar que a discriminação racial no contexto brasileiro pode ser compreendida como 
um procedimento maleável, que inclui combinações entre as variáveis atribuídas à pessoa (os traços fisionômicos) e as adquiridas (ex.: classe, convenções de gênero e outros marcadores sociais da diferença). Para os autores como Peter Fry (1991) e Yvonne Maggie (1996), os princípios classificatórios flexíveis na atribuição da cor podem ser interpretados como especificidades das relações raciais brasileiras, um país altamente miscigenado, onde são múltiplas as possibilidades de combinação e mistura de cores.

Os estudos mais recentes, sobretudo os de recorte etnográfico, ressaltam algumas dinâmicas específicas da discriminação em variados contextos. Os trabalhos de Livio Sansone $(1998,2004)$ sobre os contatos interraciais no estado da Bahia demonstraram a existência de uma gradação hierárquica entre áreas ou domínios onde a cor negra pode ser um fator de prestígio ou um empecilho nas relações sociais. Nessa lógica, o mercado de trabalho seria uma área considerada desfavorável ou dura, ocorrendo nela o máximo de discriminação para as pessoas negras, ao passo que, em alguns ambientes de lazer (e de festas populares), incluindo a Igreja Católica, denominadas de suave, haveria o mínimo de discriminação.

Demais aspectos da dinâmica da discriminação podem ser depreendidos do estudo etnográfico de Adriano Maurício (1998), realizado com usuários de ônibus no Rio de Janeiro. Segundo sua análise, os passageiros tendem a selecionar o lugar do translado de acordo com uma escala associada à cor e ao gênero dos outros passageiros. Os passageiros de pele mais clara (brancos, morenos), de ambos os sexos, escolhiam primeiro os lugares ao lado das mulheres brancas e, em segundo, das mulheres de pele mais escura (pretos, negros). Os assentos vazios contíguos aos homens eram evitados, e os lugares ao lado dos homens de pele mais escura eram a última opção. Para o autor, esta escolha está vinculada a dois pressupostos complementares. Um deles, implícito no senso comum e policial carioca, associa a cor escura a um indício de criminalidade e ameaça, principalmente rapazes pretos/negros que circulam em lugares públicos. O outro, de caráter mais explícito, diz respeito ao medo de assalto pela população carioca nos transportes coletivos, domínio em que a probabilidade de se sofrer várias violências é grande, dada a ausência de medidas de segurança pública adequadas.

Patrícia Farias (2003), por sua vez, examinou uma dimensão importante das dinâmicas locais de classificação da cor interligada à discriminação racial: a noção de território, em sua acepção simbólica 
relacionada a um ethos específico ou moralidade. A autora argumenta que as praias localizadas na zona sul da cidade do Rio de Janeiro constituemse como espaços ou áreas morais, onde seus habitués operam uma classificação social da pessoa ou dos grupos, tomando por base o local de moradia, e não apenas a cor. Assim, territorialidade serve como um marcador explícito e ajuda a subsumir a discriminação racial a uma categorização de posição social ou status, indicando, mais uma vez, a combinação de variáveis na dinâmica da discriminação.

As pesquisas mencionadas reiteram o argumento de que as percepções das vivências da discriminação precisam ser matizadas a partir dos cenários e atores envolvidos. Isto talvez ajude a entender os desafios da caracterização das discriminações raciais mais ou menos 'sutis', já que existem múltiplas possibilidades de combinação entre as discriminações em um país com alta desigualdade socioeconômica como o Brasil. Nesse ponto, alguns estudiosos assinalam que apenas as formas mais explícitas e segregatórias de discriminação são reconhecidas pela população brasileira (Guimarães, 2004).

Essa discussão pode ser enriquecida com reflexões, de caráter mais sociológico, sobre outras dimensões da discriminação no âmbito das instituições jurídicas e policiais. Ilustra essa visão a naturalização do tratamento discriminatório dado a pessoas pertencentes a certos grupos sociais, étnicos ou sociais; uma postura corriqueira entre algumas autoridades brasileiras, incluindo a polícia. Tal tratamento espraia-se pela vida cotidiana, resultando, principalmente, no desrespeito aos direitos civis deste grupo. Nesse ponto a discriminação faz par com o abuso da autoridade e com as violências.

A discriminação racial perpetrada na justiça pode ser constatada pelas pesquisas de Rubens Adorno (1996) sobre a população carcerária na cidade de São Paulo, constituída predominantemente por pardos e pretos. Os dados do trabalho do autor comprovaram a ocorrência de um tratamento discrepante em matéria de direitos humanos para os cidadãos pretos/negros do sexo masculino, dado que os mesmos estão sujeitos a probabilidades significativamente maiores de sofrerem diversas formas de violência policial, como ameaças, intimidação, agressão física e psicológica nas cadeias.

A análise de Antonio Sergio Guimarães $(1997,2004)$ sobre as matérias publicadas pela grande imprensa indicou que um dos casos mais frequentes de discriminação racial envolve a violência policial contra 
suspeitos por sua cor ou aparência. As vítimas, em geral, são homens negros, proletários, na maioria das vezes, abordados com a justificativa de que foram confundidos com ladrões ou assaltantes. A conduta de policiais orientada por estereótipos racistas foi confirmada no trabalho de Silvia Ramos e Leonarda Musumeci (2005). As autoras descrevem como se dá a construção do "elemento suspeito de cor padrão", isto é, homem 'de cor' e de classe baixa, alvo prioritário de revistas e prisões para averiguações de rotina. Quer dizer, em geral, os considerados suspeitos por sua aparência (indicador de classe ou posição social) ou cor (traço fenotípico) podem sofrer abuso de poder e agressões. Tais formas discriminatórias encontram-se respaldadas em uma ideia bastante invocada no senso comum, incluindo a polícia, de que a cor escura, seja um signo de criminalidade, em relação à qual o uso da violência física é considerado legítimo. Trata-se de uma discriminação da "rua", para utilizar a expressão de Roberto Da Matta (1985), que se dá no espaço público, o que talvez ajude a compreender o tipo de discriminação sofrida de acordo com os estereótipos raciais e de gênero.

As evidências de que os estereótipos raciais e os preconceitos sociais dos policiais acerca do criminoso potencial recaem predominantemente sobre homens jovens, pretos/negros e de regiões mais desfavorecidas, se refletem nas estatísticas sobre a violência letal, uma forma de discriminação levada ao extremo. Isto significa dizer que grande parte deste grupo sofre mortes violentas, particularmente nos locais dominados territorialmente por redes criminosas, decorrente das guerras entre quadrilhas armadas pelo controle do território e dos confrontos com a polícia.

Os argumentos apresentados revelam o aumento da vulnerabilidade do segmento juvenil em centros urbanos brasileiros, em particular Rio de Janeiro e São Paulo. As relações entre a vulnerabilidade social e em saúde desse grupo social e as situações de violência ficam evidenciadas nos dados dos homicídios, como indicam as análises baseadas em indicadores do Ministério da Saúde, descritas a seguir.

\section{Impactos das relações entre discriminação, violência e desigualdade social na saúde dos homens}

Quer por sua magnitude, quer pelas repercussões no âmbito da esfera pública como lócus privilegiado para a vitimização masculina, quer pela 
relevância como questão de saúde, a violência é um desdobramento do fenômeno das desigualdades sociais e da discriminação racial no Brasil. Os dados disponíveis sobre o dramático quadro do aumento da mortalidade por homicídio entre jovens pretos/negros e pobres no Brasil têm chamado atenção de cientistas sociais, demógrafos e epidemiologistas, sendo considerado um problema social e político (Zaluar, 1997, 2004) e de saúde pública (Minayo, 1994; Bercovich, Delassopa \& Arriaga, 1998).

Convém lembrar que o impacto demográfico da mortalidade por homicídios no Brasil já foi amplamente evidenciado na literatura das violências. Ademais, não são poucas as pesquisas que indicam o agravamento do desequilíbrio populacional entre os sexos, devido à redução da população masculina provocada pelos homicídios em todo o país. Para os estudiosos, existe uma probabilidade significativa de uma coorte de homens não chegar a idades avançadas por causa do homicídio, causando: o agravamento da diminuição de parceiros masculinos potenciais, o aumento das famílias chefiadas por mulheres e o crescimento da instabilidade do capital social das famílias (Hasenbalg \& Silva, 2003).

Em termos do recorte racial, os dados da Pesquisa Nacional por Amostra de Domicílios (Pnad) de 1998, analisados por Inácio Cano e Carlos Eugenio Ferreira (2003), indicam que os brancos constituem 54\% da população do Brasil, mas somente $45,1 \%$ das vítimas de homicídio naquele ano. Já os pardos são $39,5 \%$ da população, mas $44,5 \%$ das vítimas; e os pretos são $5,7 \%$ da população e $9,7 \%$ das vítimas. Uma das conclusões desse trabalho é que as taxas de mortalidade de pretos e pardos são, pelo menos no estado do Rio de Janeiro, muito superiores às dos brancos em todas as faixas etárias, sobretudo entre homens jovens.

O aumento do número de mortes prematuras por homicídios na população de homens pretos e pardos, a partir da adolescência, é um fenômeno típico das áreas metropolitanas brasileiras em decorrência, principalmente, da integração perversa entre redes de crime-negócio das drogas e armas, como demonstram as pesquisas pioneiras de Alba Zaluar $(1997,2004)$ no Rio de Janeiro, desde os anos 80. Poderia ser dito que a alta mortalidade masculina entre jovens pobres revela em parte a discriminação à brasileira, ou seja, uma conduta que legitima a cor e a classe como critérios que tornam a pessoa, em geral do sexo masculino, um suspeito ou criminoso.

No entanto, como lembra ainda Alba Zaluar, para compreender as razões pelas quais se observa o envolvimento precoce de homens nas 
redes criminosas - seduzidos pelo negócio da droga que lhes confere prestígio no grupo de pares, mas morte rápida -, além da dimensão socioeconômica, faz-se necessário examinar os padrões de masculinidade alterados nestes grupos, nos quais prevalece o ethos da rivalidade violenta, disposição que positiva o uso da força para a eliminação física dos considerados rivais ou opositores.

Nesse tipo de configuração, as identidades masculinas parecem estar montadas a partir da lealdade ao grupo de pares e na lógica da guerra para lograr respeito e poder (Cecchetto, 2004). A despeito das controvérsias neste campo, tem-se o propósito de destacar que, diante do crescimento da mortalidade juvenil, os estudos atuais tendem a enfatizar a vitimização dos homens, em detrimento de reflexões críticas sobre a construção social da masculinidade interligada à violência.

Objetiva-se, então, ressaltar a importância de se investigar o modo como os homens se relacionam entre si e quais são os modelos de masculinidade reforçados na sociedade, de maneira abrangente. Principalmente, cabe identificar como formas agressivas de masculinidade estão internalizadas pelos indivíduos, a ponto de serem aceitas como naturais e inquestionáveis. Desse modo, pretende-se chamar a atenção para o fato de a própria morte masculina seguir sendo, muitas vezes, justificada pela presença de uma noção atávica de masculinidade. Tal visão, baseada em uma antiga tese, embora ainda em voga, atribui à 'natureza mais agressiva' masculina a razão que pretensamente autorizaria os homens a agirem sob seu domínio no âmbito da resolução dos conflitos no cotidiano.

Obviamente, as diferenças entre as masculinidades podem ser interpretadas como acontecimentos associados às variações locais e sociais. Todavia, de modo geral, persiste a tendência em considerar a maioria das atitudes dos homens como um reflexo natural de sua constituição biológica. Isto pode ser verificado diante da preocupação em se buscar as razões para a chamada agressividade masculina, tida, na maioria das vezes, como uma espécie de ingrediente básico da própria constituição físico-química dos machos humanos. Nesta linha de pensamento, o desdobramento da agressividade em comportamentos violentos, no limite, é justificado em função da bagagem biológica carregada pelo indivíduo.

O que se verifica é como a visão simplificada de um conjunto de qualidades tidas como 'naturalmente' masculinas concorre para uma articulação entre masculinidade e violência, quando, na realidade, resulta 
de uma complexa construção cultural e socioeconômica. O perigo dessa vinculação é deixar de lado a análise das gratificações e estímulos (reais e simbólicos) que os homens recebem por expressarem sentimentos de raiva e promoverem danos a outros homens e às mulheres. Ou ainda, positivar atitudes como dominação e crueldade com mulheres, homossexuais e crianças como 'coisas de homem'. Essa perspectiva parece não contemplar a dinâmica interacional das relações de gênero, pois não vislumbra a possibilidade de que a violência feminina também exista e que as mulheres atuem nesse processo, incitando os homens ao ataque em defesa delas. Pretende-se, assim, ressaltar que essas e outras situações transmitem e reforçam padrões estereotipados de masculinidade.

Em outras palavras, antes de evocar a ideia de uma masculinidade 'naturalmente' agressiva do homem, é preciso considerar a cadeia de condicionamentos sociais e reforços positivos que os homens recebem para expressar posturas e valores de uma masculinidade violenta. A questão que deve ser discutida não é a relevância da agressividade como hormonalmente constituinte da natureza masculina, mas sim como a sociedade naturaliza a violência dos homens e entre os homens, e em que medida lhe atribui maior ou menor valor simbólico.

Esse eixo de análise indica a importância de o campo da saúde coletiva considerar o papel que algumas formações subjetivas e normas culturais têm na conformação da morbimortalidade masculina. Na mesma linha cabe pensar que as condutas arriscadas têm sido alguns dos atributos, amplamente reconhecidos e aceitos como signos da masculinidade e muitos homens vivenciam o risco como uma 'aventura' (Le Breton, 2003). Estes comportamentos, em parte expressões da busca por um ideal inatingível de masculinidade, aumentam os riscos dos homens jovens de contrair doenças sexualmente transmissíveis, incluindo a Aids, e de morrerem cedo por acidente ou homicídio (Sabo, 1997).

Especificamente, posturas da masculinidade tradicional estão associadas com a violência urbana, de gênero e sexual, fazendo emergir fatores de risco importantes para o adoecimento e morte (Schraiber, Gomes \& Couto, 2005). Convergem com essa perspectiva os achados sobre o perfil epidemiológico da saúde masculina na América Latina, que atestam a maior mortalidade masculina em todas as idades, além da sobremortalidade dos homens para a quase totalidade das causas (Gomes, Nascimento \& Araújo, 2007). Em suma, a configuração de gênero que expõe os homens jovens em várias situações de risco como agentes ou 
vítimas permite compreender por que certos agravos resultam do comportamento ou estilos de masculinidade.

\section{Considerações finais}

As análises sobre as experiências concretas de discriminação interligadas às categorias de cor/raça, gênero e classe tiveram por base as reflexões sobre desnaturalização e contextualização das diferenças. Tal visão segue a tradição da abordagem antropológica, de base universalista, que recusa correlações fixas entre características físicas e atributos morais e intelectuais (Schwarcz, 1996). É preciso, portanto, considerar os diversos arranjos culturais através dos quais as formas específicas de discriminação se manifestam no plano da interação social. Contudo, a relevância que a discriminação por cor/raça adquire na sociabilidade cotidiana e nas diferentes formas de adoecimento, ainda é pouco investigada na produção acadêmica nacional. Ademais, observa-se a escassez de pesquisas qualitativas sobre as percepções e experiências da discriminação racial no Brasil tendo por base a perspectiva da interseccionalidade.

Como foi visto, um conjunto de trabalhos tem evidenciado o quanto homens do segmento juvenil, das classes populares, classificados como negros (pretos e pardos) estão expostos a situações de discriminação e vulnerabilidade. Tal grupo aparece como vítima e protagonista da violência letal, uma forma extrema de discriminação, na maioria das vezes protagonizadas pelos e entre homens. Nesse ponto, a ausência de políticas sociais de combate à pobreza e de mudanças na esfera da segurança pública vêm contribuindo para a superposição de dois status pouco prestigiados na sociedade brasileira: a cor preta/negra e a pobreza (Zaluar, 2004).

Compreende-se que as abordagens qualitativas podem contribuir para o entendimento do impacto de algumas normas culturais na conformação das masculinidades interligada à discriminação no cenário urbano, sem perder de vista um diálogo com os estudos quantitativos. Tal tarefa implica enfrentar os desafios relacionados à busca de estratégias metodológicas mais adequadas para abordar o tema da discriminação, capazes de incorporarem a subjetividade dos sujeitos envolvidos, incluindo as percepções sobre as implicações da discriminação no processo saúde e doença. 


\section{Referências}

ADORNO, S. Violência e racismo: discriminação no acesso à justiça penal. In: SCHWARCZ, L. \& QUEIROZ. R. S (Orgs.). Raça e Diversidade. São Paulo: Edusp, Estação Ciência, 1996.

ALMEIDA-FILHO, N. et al. Social inequalities and depressive disorders in Bahia, Brazil: interactions of gender, ethnicity, and social class. Social Science \& Medicine, 59: 1.339-1.353, 2004.

BATISTA, L. E. Masculinidade, raça/cor e saúde. Ciência \& Saúde Coletiva, 10(1): 71 $80,2005$.

BERCOVICH, A.; DELASSOPA, E. \& ARRIAGA, E. J'adjunte, mais je ne corrige pas: jovens, violência e demografia no Brasil - algumas reflexões a partir dos indicadores de violência. In: COMISSÄO NACIONAL DE POPULAÇÃO E DESENVOLVIMENTO (CNPD). Jovens Acontecendo na Trilha das Políticas Públicas. Brasília: CNPD, 1998. 2v.

CANO, I. \& FERREIRA, C. E. Homicídios e evolução demográfica no Brasil: impacto da evolução demográfica na futura taxa de homicídios e a incidência dos homicídios na pirâmide populacional. In: HASENBALG, C. \& SILVA, N. V. (Orgs.). Origens e Destinos: desigualdades sociais ao longo da vida. Rio de Janeiro: Topboobks, 2003.

CECCHETTO, F. Violência e Estilos de Masculinidade. Rio de Janeiro: Editora FGV, 2004.

CECCHETTO, F. \& MONTEIRO, S. Discriminação, cor e intervenção social entre jovens: a perspectiva masculina (RJ, Brasil). Revista Estudos Feministas, 14(1): 199-218, 2006.

CHOR, D. et al. Association of weight change with ethnicity and life course: socioeconomic position among Brazilian civil servants. International Journal of Epidemiology (UK), 33(1): 100-106, 2004.

CRENSHAW, K. Documento para o encontro de especialistas em aspectos da discriminação racial relativos ao gênero. Estudos Feministas, 10(1): 171-188, 2002 .

DA MATTA, R. A Casa e a Rua. São Paulo: Brasiliense, 1985.

FARIAS, P. Pegando uma Cor na Praia: relações raciais e classificação de cor na cidade do Rio de Janeiro. Rio de Janeiro: Secretaria Municipal das Culturas, Departamento Geral de Documentação e Informação Cultural, Divisão de Editoração, 2003. (Coleção Biblioteca Carioca, 46).

FRY, P. Politicamente correto num lugar, incorreto noutro? Relações raciais no Brasil, nos Estados Unidos, em Moçambique e no Zimbábue. Estudos Afro-Asiáticos, (21): 167-177, 1991. 
GOMES, R.; NASCIMENTO E. F. \& ARAÚJO, F. C. Por que os homens buscam menos os serviços de saúde do que as mulheres? As explicações de homens com baixa escolaridade e homens com ensino superior. Cadernos de Saúde Pública, 23(3): 565-574, 2007.

GREIG, A. et al. Gender and Aids: time to act. Aids, 22 (supl. 2): S35-S43, 2008.

GUERREIRO, I.; AYRES, J. R. \& HEARST, N. Masculinidade e vulnerabilidade ao HIV de homens heterossexuais, São Paulo. Revista de Saúde Pública, 36(4): 5060, 2002.

GUIMARÃES, A. S. Racismo e restrição de direitos individuais: a discriminação racial publicizada. Estudos Afro-Asiáticos, 34: 51-78, 1997.

GUIMARÃES, A. S. Preconceito e Discriminação: queixas de ofensas e tratamento desigual dos negros do Brasil. São Paulo: Fundação de Apoio à Universidade de São Paulo, Editora 34, 2004.

HARELL, J. P. \& HALL, S. Physiological responses to racism and discrimination: an assessment of the evidence. American Journal of Public Health, 93(2): 243-247, 2003.

HASENBALG, C. \& SILVA, N. V. (Orgs.). Origens e Destinos: desigualdades sociais ao longo da vida. Rio de Janeiro: Topboobks, 2003.

HERINGER, R. Desigualdades raciais no Brasil: síntese de indicadores e desafios no campo das políticas públicas. Cadernos de Saúde Pública, 18: S57-S65, 2002.

JACCOUD, L. B \& BEGHIN, N. (Orgs.). Desigualdades Raciais no Brasil: um balanço da intervenção governamental. Brasília: Ipea, 2002

KRIEGER, N. Does racism harm health? Did child abuse exist before 1962? On explicit questions, critical scene, and current controversies: an ecosocial perspective. American Journal of Public Health, 93(2): 194-199, 2003.

LAGUARDIA, J. O uso da variável 'raça' na pesquisa em saúde. Physis: Revista de Saúde Coletiva, 14 (2): 197-232, 2004.

LE BRETON, D. Adeus ao Corpo: antropologia e sociedade. Campinas, São Paulo: Papirus, 2003.

LEAL, M. C.; GAMA, S. G. N. G. \& CUNHA, C. B. Desigualdades raciais, sociodemográficas e na assistência pré-natal e ao parto, 1999-2001. Revista de Saúde Pública, 39(1): 100-107, 2005.

LOPES, F.; BUCHALLA, C. \& AYRES, J. R. Mulheres negras e não negras e vulnerabilidade ao HIV/Aids no Estado de São Paulo, Brasil. Revista de Saúde Pública, 41(2): 39-46, 2007.

MAGGIE, Y. Aqueles a quem foi negada a luz do dia: as categorias de cor e raça na cultura brasileira. In: MAIO, M. C. \& SANTOS, R. V. (Orgs.). Raça, Ciência e Sociedade. Rio de Janeiro: Editora Fiocruz, 1996. 
MAIO, M. \& MONTEIRO, S. Tempo de racialização: o caso da saúde da 'população negra' no Brasil. História, Ciências, Saúde - Manguinhos, 12(2): 419-446, 2005.

MAIO, M. et al. Cor/raça no estudo pró-saúde: resultados comparativos de dois métodos de autoclassificação no Rio de Janeiro. Cadernos de Saúde Pública, 21(1): 109-118, 2005.

MAURÍCIO, A. Medo de Assalto, 1998. Dissertação de Mestrado, Rio de Janeiro: Instituto de Filosofia e Ciências Sociais, Universidade Federal do Rio de Janeiro.

MINAYO, M. C. A violência social sob a perspectiva da saúde pública. Cadernos de Saúde Pública, 10(1): 7-18, 1994.

MONTEIRO, S. Desigualdades em saúde, raça e etnicidade: questões e desafios. In: MONTEIRO, S. \& SANSONE, L. (Orgs.). Etnicidade na América Latina: um debate sobre raça, saúde e direitos reprodutivos. Rio de Janeiro: Editora Fiocruz, 2004.

MONTEIRO, S. STD/Aids prevention in African countries with Portuguese as their official language: a literature review in social science and health. Cadernos Saúde Pública, 25: 680-686, 2009.

NOGUEIRA, O. Preconceito de Marca: as relações raciais em Itapetininga. São Paulo: Edusp, 1998.

PAGER, D. Medir discriminação. Tempo Social, 18(2): 65-88, 2006.

PARKER, R. \& AGGLETON, P. HIV and Aids related stigma and discrimination: a conceptual framework and implications for action. Socio Science \& Medicine, 57: 13-24, 2003.

RAMOS, S. \& MUSUMECI, L. Elemento Suspeito: abordagem policial e discriminação no Rio de Janeiro. Rio de Janeiro: Civilização Brasileira, 2005.

RODRIGUES, M. B. Interculturalidade: por uma genealogia da discriminação. Psicologia Social, 19(3): 55-61, 2007.

SABO, D. Masculinities and men's health: moving toward post-superman era prevention. In: KIMMEL. M. \& MESSER, M. (Eds.). Men's Lives. Boston: Allyn \& Bacon, 1997.

SANSONE, L. Pai preto, filho negro. Trabalho, cor e diferenças geracionais. Estudos Afro-Asiáticos, 25: 73-98, 1998.

SANSONE, L. Negritude sem Etnicidade: o local e o global nas relações raciais e na produção cultural negra do Brasil. Salvador: Edufba, Pallas, 2004.

SCHRAIBER, L. B.; GOMES, R. \& COUTO, M. T. Homens e saúde na pauta da saúde coletiva. Ciência \& Saúde Coletiva, 10(1): 7-17, 2005.

SCHWARCZ, L. M. As teorias raciais, uma construção histórica de finais do século XIX: o contexto brasileiro. In: SCHWARCZ, L. M. \& QUEIROZ, R. S. (Orgs.). Raça e Diversidade. São Paulo: EdUSP, Estação Ciência, 1996. 
STOLKE, V. Sexo está para gênero assim como raça para etnicidade? Estudos AfroAsiáticos, (20): 101-119, 1991.

STUBER, J.; MEYER, I. \& LINK, B. Stigma, prejudice, discrimination and health. Social Science \& Medicine, 67: 351-357, 2008.

TRAVASSOS, C. \& WILLIAMS, D. The concept and measurement of race and their relationship to public health: a review focused on Brazil and the United States. Cadernos de Saúde Pública, 20(3): 660-678, 2004.

ZALUAR, A. Gangues, galeras e quadrilhas: globalização, juventude e violência. In: VIANA, H. (Org.). Galeras Cariocas: territórios de conflitos e encontros culturais. Rio de Janeiro: Editora da UFRJ, 1997.

ZALUAR, A. A Integração Perversa: pobreza e tráfico de drogas. Rio de Janeiro: Editora FGV, 2004.

WAISELFISZ, J. Mapa da Violência: os jovens da América Latina. São Paulo, Brasília: Instituto Sangari, Rede de Informação Tecnológica Latino-Americana, Ministério da Justiça, 2008.

WILLIAMS, D.; NEIGHBORS, H. \& JACKSON, J. Racial/ethnic discrimination and health: findings from community studies. American Journal of Public Health, 93(2): 200-208, 2003. 


\section{6}

\section{A Sexualidade Masculina em Foco}

Romeu Gomes

\section{Reduções da sexualidade masculina}

A sexualidade masculina tem estado em foco, não só em fóruns acadêmicos como também no âmbito da mídia, por meio de matérias, entrevistas ou propagandas. Revistas nas bancas de jornal a ela dedicam seções especiais. Anúncios ou propagandas sobre a saúde do homem quando veiculados na mídia ou na Internet - em geral é dela que tratam.

No entanto, observa-se que nem sempre a sexualidade masculina é considerada de uma forma abrangente. Ao contrário, a temática costuma ser focalizada a partir de perspectivas reducionistas.

A revista Men's Health, por exemplo, costuma restringir a avaliação da competência sexual aos desempenhos sexuais (Gomes, 2008). O leitor é, então, convidado a ler sobre formas de se obter mais êxitos nos relacionamentos sexuais e como chegar ao ápice do prazer. Assim, técnicas e artefatos são apresentados para que os homens possam melhorar o seu desempenho sexual.

Essa revista, que circula em vários países, foi estudada por outros autores (Boni, 2002; Stibbe, 2004; Werkmeister, 2003). Entre as principais críticas ao periódico em pauta, destacam-se as seguintes: a abordagem da revista, ancorada numa perspectiva de medicalização, incentiva uma obsessão do corpo; estimula benefícios de estilos de vida, desconsiderando um corpo masculino com suas fronteiras, seus rituais, suas inquietudes, seus medos de invasão e perda de identidade; veicula mensagens associadas a uma padronização da beleza, moda, saúde e vida amorosa; tanto 
disponibiliza informações sobre a saúde, como reproduz um modelo de masculinidade hegemônica, induzindo a condutas que podem comprometer a saúde do homem bem como a das mulheres.

Enfim, a revista expressa, como modelo, um homem euroamericano, heterossexual, com alta escolaridade e detentor de um considerável status econômico, sem destacar a existência das masculinidades, tampouco a possibilidade de haver enredos e personagens sexuais que se recriam a partir de outros padrões, sem ser o hegemônico.

Em sites da Internet, quando se busca informações com as palavras "saúde sexual masculina", comumente observa-se que o assunto é reduzido à disfunção erétil e à ejaculação precoce. Por vezes, as matérias acerca dessas expressões consistem em explicações sobre o que elas significam ou em orientações como proceder no caso de um homem ter esses problemas.

O prazer sexual, quase sempre, quando tratado, aparece como a promessa de resultado de uso de determinado medicamento ou de intervenções específicas de caráter cirúrgico. Outra redução comum que ocorre nesses sites se relaciona ao aumento do tamanho do pênis. Em todas essas matérias, não só as dos sites mais populares mas também aqueles de clínicas ou hospitais médicos, constata-se que a sexualidade dos homens, em geral, é reduzida ao órgão sexual masculino.

Gomes e Nascimento (2006) identificaram outra redução da sexualidade masculina no campo da saúde pública: a de focalizá-la como infectante, associando-a muito mais à doença do que à saúde. Os autores observaram que, embora as pesquisas tivessem de tratar das doenças sexualmente transmissíveis devido à forte participação de homens nos perfis epidemiológicos relacionados a essas doenças, poderiam ampliar a discussão, contemplando questões sobre sexualidade masculina especificamente e sobre aquelas relativas às relações de gênero, para que pudessem melhor abordar os problemas das doenças.

Não é só a sexualidade masculina que costuma ser reduzida. Podese observar fenômeno semelhante na abordagem da sexualidade feminina, tanto no campo midiático, quanto no âmbito específico da saúde. Por isso, faz-se necessário apontar alguns marcos conceituais sobre a sexualidade em geral para avançar no debate sobre a sexualidade masculina em específico. Ainda que se focalize a sexualidade masculina, não se pode desconsiderar a feminina, direta ou indiretamente, "uma vez que tanto a sexualidade dos homens quanto a das mulheres são elaboradas e se tornam 
viáveis ou não dentro do cenário das relações de gênero culturalmente construídas e socialmente demarcadas" (Gomes, 2008: 84).

\section{Marco conceitual sobre a sexualidade em geral}

Aspectos da concepção de Michel Foucault podem servir de ponto de partida para uma reflexão sobre a sexualidade, situando-a em um escopo mais amplo de discussão. Para ele, a sexualidade é um

nome que se pode dar a um dispositivo histórico: não à realidade subterrânea que se apreende com dificuldade, mas à grande rede da superfície em que a estimulação dos corpos, a intensificação dos prazeres, a incitação ao discurso, a formação dos conhecimentos, o reforço dos controles e das resistências, encadeiam-se uns nos outros, segundo algumas grandes estratégias de saber e de poder. (Foucault, 1988: 100)

Essas palavras evidenciam que a sexualidade é uma construção histórica e se estrutura a partir da articulação de saberes e poderes relacionados aos prazeres sexuais. Esse famoso pensador francês quer discutir mais a lógica da norma do que a da interdição, assinalando que o lícito e o ilícito vão dar lugar ao normal e ao patológico. Não enfoca o assunto em questão a partir de pulsão ou instinto, mas como um dispositivo histórico ancorado em discursos, saberes e poderes.

Segundo Foucault (1988), nos três últimos séculos que precederam o século XX, em torno do sexo, houve uma verdadeira explosão discursiva. (...) O eixo desses discursos não foi unicamente o da moral, mas também o da racionalidade, com o propósito de administrar o sexo para que houvesse um padrão ótimo de funcionamento para o bem de todos. Ainda segundo Foucault, o silêncio acerca do sexo que impetrou nesses séculos não pode ser interpretado como ausência do discurso. No não falar, cabe interrogar quem pode falar e o que tem autorização para ser dito. (Gomes, 2008: 84)

Assim, caminhando em uma lógica distinta da repressão, de acordo com essa concepção, "o poder sobre o sexo não inibe ou reprime uma essência verdadeira, ele cria verdades sobre o sexo que operam produzindo relações de poder, que são imanentes ao seu funcionamento" (Monteiro, 2000: 21). 
A concepção de Gagnon (2006) também pode constituir-se em um marco conceitual importante para ampliar a discussão sobre a sexualidade. Para esse autor, a sexualidade diferencia-se nos distintos espaços cultuais e ao longo das épocas históricas, fazendo com que, muito mais que um comportamento individual, seja uma consequência da cultura. Ele também diferencia comportamento de conduta sexual: o comportamento sexual humano e não humano - se relaciona a práticas corporais, ao passo que a conduta sexual envolve uma avaliação de comportamento por parte dos indivíduos com base em significados culturais e sociais.

Empregar, então, conduta sexual no lugar de comportamento sexual é deslocar a perspectiva dos determinantes dos impulsos ou das energias sexuais para a concepção de uma sexualidade socialmente construída.

A conduta sexual, ainda segundo Gagnon, pode ser compreendida a partir de roteiros culturais (elementos simbólicos e não verbais) que a ela impõem uma sequência. As pessoas se apropriam desses roteiros, editando-os, reescrevendo-os e organizando-os para atender às exigências concretas de suas vidas. Em outras palavras, as pessoas primeiro são socializadas como aprendizes dos cenários culturais e, à medida que vão encenando os roteiros, vão modificando-os diante das situações concretas em que se encontram.

É essa relação frouxa entre os roteiros e o comportamento concreto que torna tão problemática e invalida boa parte da psicologização transcultural e histórica. Todavia, essa mesma relação flexível entre os roteiros e o comportamento concreto é crucial para os processos de desenvolvimento, bem como para as mudanças individuais e sociais. (Gagnon, 2006: 125)

Bozon também entende a sexualidade humana como uma construção social, em que atividade mental e atividade corporal se articulam. Para ele, os seres humanos "não só necessitam de um aprendizado social para saber de que maneira, quando e com quem agir sexualmente, como não conseguem agir sem dar um sentido aos seus atos" (Bozon, 2004: 13).

Nessa concepção, embora a sexualidade seja entendida como uma esfera específica do comportamento humano, não é vista como autônoma, uma vez que depende de rituais, representações e histórias que a encenem. Além de aprenderem os procedimentos sexuais, as pessoas precisam atribuir sentidos ao que fazem e mentalmente elaborar o que vão fazer e, assim, ao longo de suas vidas, vão produzindo ou reproduzindo constantes interpretações e reinterpretações sobre a sexualidade. 
Ainda que haja diferenças epistemológicas, as concepções aqui apresentadas podem constituir um marco conceitual que - diferentemente da lógica que focaliza as energias biológicas - adota uma visão cultural da sexualidade e aponta para processos sociais complexos.

\section{Sobre a sexualidade masculina}

A conduta sexual masculina costuma ser influenciada por algumas ideias que circulam no imaginário social, entre as quais se destacam: preocupação com o tamanho do pênis, a importância do coito na relação sexual, a exigência de se experimentar uma ereção imediata e a redução da sexualidade à área genital. Essas ideias circulam com tanta força persuasiva e sedutora que podem ser consideradas pelos homens como verdades da vida sexual masculina (Nogales, 2006).

Outro aspecto que, em geral, vem à tona na discussão sobre a sexualidade masculina é a masturbação. Ela - que aparece como uma experiência quase universal - pode exercer um papel importante, na medida em que comumente precede as relações sexuais entre parceiros. Diferentemente das mulheres, que tendem a se iniciar sexualmente pela experiência amorosa, os homens costumam experimentá-la como porta de entrada para o exercício da sexualidade (Bozon, 2004).

A masturbação pode servir para autodescoberta tanto masculina quanto feminina. Entretanto, no caso dos homens, além de possibilitar uma autodescoberta (tomando a ereção e a ejaculação como indicadores da virilidade e da potência), pode ser uma preparação para que a sexualidade masculina seja atestada na relação com a mulher. Ampla pesquisa brasileira (Almeida, 2007) concluiu que a maioria de homens e mulheres pertencentes a segmentos com ensino superior é a favor da masturbação masculina (71\%) e da feminina $(74 \%)$.

A heterossexualidade - entendida como orientação ou preferência - também costuma ser destacada, por alguns autores, como um eixo estruturante para a sexualidade masculina, tornando-se quase como uma pertença exclusiva dessa sexualidade.

E os homens que querem viver sexualidades não heterocentradas são estigmatizados como não sendo homens normais, acusados de serem 'passivos', e ameaçados de serem associados a mulheres e tratados como elas. Pois se trata bem disto, ser homem corresponde ao fato de ser ativo 
(...) De fato, o duplo paradigma naturalista que define, por um lado, a superioridade masculina sobre as mulheres e, por outro lado, normatiza o que deve ser a sexualidade masculina produz uma norma política androheterocentrada e homofóbica que nos diz o que deve ser o verdadeiro homem, o homem normal. (Welzer-Lang, 201: 469)

A associação estabelecida entre heterossexualidade e as ideias de ativo e dominador, diferenciando-se das ideias de passivo e submisso relacionadas à homossexualidade, tem forte acento na cultura sexual brasileira, servindo tanto para a relação homem-mulher, quanto para aquela que se estabelece entre homens (Parker, 1991). Assim, às vezes, as relações sexuais praticadas entre homens nem sempre comprometem a imagem masculina:

(...) nota-se que, através dos termos 'atividade' e 'passividade', encontramos atribuições de dominação e submissão, instaurando uma relação hierárquica: a atividade, o ato de penetrar outro homem, sempre é 'apresentada' como uma forma positiva de autoafirmação masculina e significa poder em relação à passividade. (Cecchetto, 2004: 55)

No senso comum, há outras situações em que se tolera a transgressão da heteronormatividade. Como mencionado em uma revisão da literatura, há, pelo menos, três situações em que isso pode ocorrer: as relações sexuais episódicas durante a infância; as ocorridas entre homens quando estão encarcerados e as praticadas por homens trabalhadores do sexo com os seus clientes com fins comerciais (Gomes \& Nascimento, 2006).

A flexibilização das orientações ou preferências sexuais ocorrem por conta da premissa de que homossexualidade e homossexuais são rótulos que devem ser vistos mais a partir das diferenças histórico-culturais do que pela ordem natural, traduzido-se na ideia de que o gênero e a sexualidade são socialmente aprendidos. Assim, a quebra ou não das imposições sobre os papéis sexuais vai depender das mudanças que ocorrem no âmbito das culturas em geral (Gagnon, 2006).

Por último, observa-se que os aspectos que costumam ser associados à sexualidade masculina, ainda que não sejam determinantes para todos os homens, não podem ser desconsiderados, uma vez que, segundo a literatura específica, eles costumam atravessar as fronteiras entre raças/etnias e classes sociais. 


\section{Narrativas sexuais masculinas}

As narrativas sexuais masculinas nem sempre revelam enredos universais ou determinados por modelos hegemônicos que estruturam a construção da masculinidade. Por vezes, tais modelos são reproduzidos e, em outros momentos, não só são ressignificados como também abandonados para que outras narrativas sejam editadas. No sentido de discutir essas ideias, retoma-se estudo realizado no Rio de Janeiro sobre narrativas sexuais de homens (Gomes, 2008).

Nesse estudo, entrevistaram-se dois grupos de homens. O primeiro era composto de dez homens, com as seguintes características: 1) idades entre 45 e 57 anos; $_{i}$ ) a maioria se autodeclarou parda 3 ) nove deles cursaram até a quarta série do ensino fundamental e um respondeu não ter nenhuma instrução; 4) nove eram casados e um afirmou ser solteiro; 5) renda mensal média de 3,3 salários mínimos, que, à época da pesquisa era de $\mathrm{R} \$ 305,00 ; 6)$ as principais atividades eram as de carpinteiro, pintor e armador, além de ascensorista, mestre de serviços operacionais, pedreiro e servente $; 7)$ a maioria deles residia em municípios vizinhos à cidade do Rio de Janeiro.

O segundo grupo era composto por oito homens, com as seguintes características: 1) idades entre 40 e 64 anos; $^{2}$ ) quatro se autodeclararam brancos; dois, pretos e dois, pardos; 3 ) quatro eram casados e quatro, solteiros $; 4)$ renda mensal média aproximada de 15 salários mínimos $;$ 5) as principais atividades exercidas eram as de professor, psicólogo, engenheiro, advogado e economista $\left.{ }_{i} 6\right)$ todos residiam na cidade do Rio de Janeiro.

Esse estudo construiu uma metanarrativa, tentando sintetizar as diversas narrativas individuais.

Assim, por meio de sínteses dos diferentes sentidos que os sujeitos atribuem às suas experiências, consegui abstrair um roteiro e personagens que modelam as histórias sexuais masculinas. Isso não significa que os sujeitos tenham ou vivenciem uma só história, mas que, ao construírem suas sexualidades, levam em conta um roteiro cultural que lhes serve de modelo. (Gomes, 2008: 147)

Nessa metanarrativa, observam-se enredos que se constroem, tendo como referência a heterossexualidade: 
O homem não deve ser gay. O homem não deve ser bicha. (Homem 1/ Grupo I)

[O homem] tem que procurar mulher. (Homem 3/Grupo I)

[Homens que] têm um companheiro igual a ele mesmo (...) não deixam de ser homem também. (...) Mas têm a vida deles (...) meio isolada. (Homem 4/Grupo II)

Eu sempre tive preferências por outros garotos (...) E as crises começam a acontecer (...) e eu tive que desenrolar, comigo mesmo, que eu não ia abrir para ninguém (...) cheguei aos meus 47 anos bem [não tendo] que dar satisfação; você tem que ser superior às cobranças. (Homem 5/ Grupo II)

Esses fragmentos de narrativas contêm um espectro amplo de opiniões sobre a heterossexualidade. Nas falas, observam-se posições de adesão à norma (primeiro e segundo depoimentos), de abandono da norma, reconhecendo-se o isolamento que esta atitude acarreta (terceiro depoimento), e até mesmo a negação da norma (quarto depoimento). Sobre isso, constata-se que os homens com ensino superior conseguiam relativizar um pouco mais a heteronormatividade.

Outro aspecto a ser destacado na metanarrativa se relaciona ao fato de que - embora os homens sejam considerados os dominadores - a mulher é protagonista comum e, em determinadas situações, pode ensinar o ofício da sexualidade para os homens. Assim, submetendo-se à passividade momentânea, o homem se exercitaria para ser sexualmente ativo.

Observou-se também que as primeiras experiências sexuais entendidas como penetração - por vezes eram atravessadas por medos e inseguranças. Nem sempre os homens conversavam com colegas ou amigos sobre esses sentimentos. Entre os pares, costumavam ocorrer mais narrativas sobre conquistas do que sobre os sentimentos envolvidos em suas experiências, assinalando principalmente a frequência e a intensidade dos atos sexuais, uma vez que isso pode indicar o grau de virilidade do sujeito da narrativa.

O enredo da metanarrativa do estudo em questão nem sempre consegue fundir erotismo e sentimento. Assim:

Embora haja um ideal de fusão, em que amor e paixão coexistam no espaço da relação sexual, costuma haver dois caminhos paralelos que 
parecem nunca se encontrar, sendo trilhados por personagens distintos. Quando esse ideal se torna real, os homens descobrem um 'sexo bonito' ou um 'sexo gostoso'. (Gomes, 2008: 148)

Em apenas uma narrativa, aparecem, de forma implícita, as práticas de sexo oral e anal. No entanto, mais recentemente, parece que o sexo oral e o anal vêm sendo mais explicitados nos discursos de jovens masculinos e femininos. Em uma ampla pesquisa brasileira (Heilborn, 2006), constatouse que, em relação ao sexo oral, $70 \%$ das moças e $85 \%$ dos rapazes responderam ter experimentado fellatio (estímulo sexual do pênis por contato oral) ${ }_{i}$ e $79 \%$ das moças e $82 \%$ dos rapazes disseram ter experiência de cunnilingus (contato oral com órgão sexual feminino). Quanto ao sexo anal, concluiu-se que $61 \%$ dos rapazes e $25 \%$ das moças experimentaram tal prática.

Outra pesquisa realizada com ampla amostra brasileira conclui que "para cada degrau que se sobe nas faixas de idade, cai a aprovação a um maior liberalismo sexual" (Almeida, 2007: 161). No que se refere a sexo anal, constatou-se que foi rejeitado por $74 \%$ dos sujeitos da amostra.

$\mathrm{O}$ estudo da metanarrativa aqui focalizado conclui que:

[ela] traduz um modelo padrão das histórias sexuais masculinas, o que não significa que não possa ser subjetivada. Ao tomá-la como referência no entendimento da construção social dos enredos sexuais masculinos, os estudos, os fóruns e as intervenções da saúde não podem desconsiderar a possibilidade de os sujeitos reinterpretarem e reinventarem o que é culturalmente determinado, pois isso os destituiria do papel de autores e atores das narrativas. (Gomes, 2008: 152)

Essa metanarrativa se articula com outras narrativas - de duas pesquisas realizadas com homens jovens na cidade do Rio de Janeiro (Nascimento \& Gomes, 2009; Rebello \& Gomes, 2009), indicando que os enredos sexuais podem ultrapassar tanto fronteiras entre classe como as de universo geracional.

\section{Pontos de partida para a continuidade do debate}

Para que o debate acerca da sexualidade masculina continue, faz-se necessário conceber a sexualidade em geral em uma perspectiva ampliada. Destacam-se os seguintes pontos de partida: 
- Levar em conta tanto o foco da prevenção de doenças como o da promoção da saúde, articulando as dimensões física e simbólica da sexualidade.

- Promover um deslocamento das reduções da sexualidade para uma abordagem mais ampla, como a da Organização Mundial da Saúde (OMS), que a concebe como uma energia que faz com que as pessoas se sintam motivadas para encontrar amor, contato, ternura e intimidade, fazendo parte do modo como se sentem, se tocam, são tocadas e influenciando a saúde física e mental.

- Entender que a sexualidade, em geral, envolve preferências, predisposições, experiências, experimentações e descobertas, que podem variar entre os diferentes segmentos sociais.

- Considerar a saúde sexual como aquela que, além de ser relacionada ao prazer e ao bem-estar, contribui para a "construção de nossas identidades pessoais e sociais (para estabelecer nosso lugar no mundo, nossas redes de sociabilidade, o modo como vemos e como os outros nos veem)" (Carrara, 2005: 19).

- Situar a discussão no campo dos seguintes direitos:

Direito de viver e expressar livremente a sexualidade sem violência, discriminações e imposições e com respeito pleno pelo corpo do(a) parceiro(a). Direito de escolher o(a) parceiro(a) sexual. Direito de viver plenamente a sexualidade sem medo, vergonha, culpa e falsas crenças. Direito de viver a sexualidade independentemente de estado civil, idade ou condição física. Direito de escolher se quer ou não quer ter relação sexual. Direito de expressar livremente sua orientação sexual: heterossexualidade, homossexualidade, bissexualidade, entre outras. Direito de ter relação sexual independente da reprodução. Direito ao sexo seguro para prevenção da gravidez indesejada e de DST/HIV/Aids. Direito a serviços de saúde que garantam privacidade, sigilo e atendimento de qualidade e sem discriminação. Direito à informação e à educação sexual e reprodutiva. (Brasil, 2006: 6)

Assim, considerar a sexualidade como saudável - seja de homens, seja de mulheres - significa também integrá-la em uma perspectiva de cidadania sexual, em que as diferenças de gênero e das identidades sexuais são aceitas, sem desconsiderar "as relações de gênero e de poder, o sexismo e a homofobia, assim como o racismo e a pobreza" (Paiva, 2006: 26). 


\section{Referências}

ALMEIDA, A. C. A Cabeça do Brasileiro. Rio de Janeiro: Record, 2007.

BONI, F. Framing media masculinities: men's lifestyle magazines and the biopolitics of the male body. European Journal of Communication, 17(4): 465-478, 2002.

BOZON, M. Sociologia da Sexualidade. Rio de Janeiro: Editora FGV, 2004.

BRASIL. Ministério da Saúde. Secretaria de Atenção à Saúde. Departamento de Ações Programáticas Estratégicas. Direitos Sexuais, Direitos Reprodutivos e Métodos Anticoncepcionais. Brasília: Ministério da Saúde, 2006.

CARRARA, S. O Centro Latino-Americano em Sexualidade e Direitos Humanos e o 'lugar' da homossexualidade. In: GROSSI, P. et al. (Orgs.). Movimentos Sociais, Educação e Sexualidade. Rio de Janeiro: Garamond, 2005.

CECCHETTO, F. R. Violência e Estilos de Masculinidade. Rio de Janeiro: Editora FGV, 2004.

FOUCAULT, M. História da Sexualidade. Rio de Janeiro: Graal, 1985. v. 1.

GAGNON, J. H. Uma Interpretação do Desejo: ensaios sobre o estudo da sexualidade. Rio de Janeiro: Garamond, 2006.

GOMES, R. Sexualidade Masculina, Gênero e Saúde. Rio de Janeiro: Editora Fiocruz, 2008.

GOMES, R. \& NASCIMENTO, E. F. A produção do conhecimento da saúde pública sobre a relação homem-saúde: uma revisão bibliográfica. Cadernos de Saúde Pública, 22(5): 901-911, 2006.

HEILBORN, M. L. Experiência da sexualidade, reprodução e trajetórias biográficas juvenis. In: HEILBORN, M. L. et al. (Orgs.) O Aprendizado da Sexualidade: reprodução e trajetórias sociais de jovens brasileiros. Rio de Janeiro: Garamond, Editora Fiocruz, 2006.

MONTEIRO, M. Tenham Piedade dos Homens: masculinidades em mudança. Juiz de Fora: Feme, 2000.

NASCIMENTO, E. F. \& GOMES, R. Iniciação sexual masculina: conversas íntimas para fóruns privados. Ciência \& Saúde Coletiva, 14(4): 1.101-1.110, 2009.

NOGAlES, A. M. Mitos Sexuales de la Masculinidad. Madrid: Biblioteca Nueva, 2006.

PAIVA, V. et al. Uso de Preservativos: pesquisa nacional. MS/Ibope, 2003. Disponível em <www.aids.gov.br>. Acesso em: 11 out. 2007.

PARKER, R. G. Corpos, Prazeres e Paixões: a cultura sexual no Brasil contemporâneo. São Paulo: Best Seller, 1991. 
REBELLO, L. E. F. S. \& GOMES, R. Iniciação sexual, masculinidade e saúde: narrativas de homens jovens universitários. Ciência \& Saúde Coletiva, 14(2): 653-660, 2009.

STIBBE, A. Health and the social construction of masculinity in men's health magazine. Men and Masculinities, 7(1): 31-51, 2004. Disponível em: <http:// jmm.sagepub.com>. Acesso em: 1 ago. 2007.

WELZER-LANG, D. A construção do masculino: dominação das mulheres e homofobia. Estudos Feministas, 2: 460-482, 2001.

WERKMEISTER, M. Men's Magazines in Germany. Disponível em: <www.theoryhead.com/gender/germany.htm>. Acesso em: 7 out. 2004. 


\section{De Quem É o Problema? Os homens e a medicalização da reprodução}

Pedro Nascimento

O objetivo deste capítulo é discutir os caminhos, as negociações e as pressões que homens e casais têm experimentado na busca por um filho, ao serem identificadas dificuldades para alcançar esse fim. Pretendese, com isso, perceber como a dimensão do gênero está presente na construção desse desejo. Fazer essa reflexão implica uma abordagem que extrapole o nível das relações conjugais, tornando-se necessário levar em conta debates desenvolvidos nas últimas décadas acerca da relação entre gênero, reprodução e saúde.

Ao mesmo tempo que a dimensão do gênero é central para essa discussão, não é possível desvinculá-la das questões mais gerais sobre a estruturação dos serviços de saúde no Brasil. Essa perspectiva pretende ressaltar importantes contribuições de feministas que evidenciam que gênero não é o único eixo de diferenciação social, devendo-se considerar as diferenças entre as mulheres e entre os homens devido à classe, raça, religião ou etnicidade (Moore, 1997).

Considerar esses vários eixos de diferenciação nos leva a problematizar o discurso cada vez mais comum sobre os milagres que as novas tecnologias reprodutivas (NTR) têm operado. Essa ideia de milagre realizado pelo progresso da ciência que estaria aperfeiçoando a natureza, dando-lhe 'uma mãozinha' (Franklin, 1997), muito facilmente é colocada no campo da ampliação dos direitos individuais e, na mesma velocidade, celebrada como mais um elemento para a consolidação dos direitos reprodutivos.

A pesquisa etnográfica na qual minhas reflexões se baseiam foi desenvolvida no âmbito do doutorado em antropologia social 
(Nascimento, 2009). ${ }^{1}$ Uma primeira fase da pesquisa foi realizada em um hospital público de Porto Alegre em que eram oferecidos serviços de reprodução assistida. ${ }^{2}$ Aí fiz observação participante e entrevistei casais que estavam fazendo consultas ou que já tinham iniciado o tratamento para 'infertilidade'. De setembro a novembro de 2006 e entre março de 2007 e julho de 2008, além de pesquisa com 17 casais localizados via serviço hospitalar de maternidade assistida, estabeleci contato com os serviços de saúde pública em três comunidades de Porto Alegre, onde passei a realizar entrevistas com mais de uma dezena de mulheres com 'dificuldade para engravidar'.

As situações aqui trabalhadas dizem respeito principalmente à primeira fase da pesquisa desenvolvida no hospital. Esta é uma parte dos sujeitos investigados que haviam decidido "pagar o preço" do tratamento (Nascimento, 2007b). Esta adesão ao tratamento não é vivenciada da mesma forma por todos os casais que involuntariamente não têm filhos. Muitos desistirão dele ou nem sequer vão iniciá-lo. Diversos elementos estão em jogo nessa definição, sendo classe um dos principais.

O mais importante resultado dessa opção metodológica foi a percepção de um recurso diferenciado por parte das pessoas ao serviço de saúde. Para aqueles que estavam na busca pelos serviços no hospital, havia a expectativa de que teria uma solução para um problema. O contato com as pessoas nas comunidades começou a demonstrar que esse processo não era tão evidente. Passei a ver que, para muitos, nem mesmo haveria um problema em termos médicos a ser resolvido e o que parecia a mesma questão - a ausência involuntária de filhos - não era formulada sempre nos mesmos termos. ${ }^{3}$

1 Agradeço o apoio recebido do Programa Internacional de Bolsas de Pós-Graduação da Fundação Ford (IFP) para a realização do doutorado no Programa de Pós-Graduação em Antropologia Social da Universidade Federal do Rio Grande do Sul. Agradeço também à Fundação Carlos Chagas, que coordena o IFP no Brasil, e ao CNPq pela concessão de bolsa na fase final do doutorado.

2 Trata-se de um hospital público que oferece um serviço de reprodução assistida onde as pessoas que a ele recorrem arcam com os custos dos medicamentos e é a principal referência para quem não pode pagar os serviços em clínicas privadas. Todos os nomes das pessoas, dos serviços e das comunidades pesquisadas foram alterados.

3 Evitarei, aqui, o uso do termo infertilidade para referir as situações de pessoas que involuntariamente não tinham filhos. A noção de ausência involuntária de filhos (childlessnes) está mais próxima do contexto da segunda fase da pesquisa, em que a categoria médica de infertilidade como uma "patologia" não se aplica. Para essa discussão, ver Inhorh e Balen (2002), Vargas (1999) e Diniz (2002). 
Meus dados de campo questionam a noção de facilidade do acesso a esses serviços de reprodução assistida. Ao mesmo tempo, levam a partilhar do debate feminista que aponta para a diferença de contextos e sujeitos em campo que permitem a emergência e disseminação dessas tecnologias, o que sugere cautela na adoção direta da noção de direitos reprodutivos como sendo capaz de abarcar todas as questões que emergem no contexto da utilização das novas tecnologias conceptivas (NTCs).

Particularmente nas discussões sobre a disseminação das NTCs, muitas feministas têm apontado como, sob o argumento de ajudar as mulheres a superarem o sofrimento por não poderem concretizar o sonho de ter um filho, essas tecnologias reforçam a maternidade como uma vocação natural das mulheres. Ao fazerem isso, levam as mulheres que não podem ter filhos seus a se sentirem incompletas. A noção de que o desejo de ter filhos é um destino natural das mulheres, à medida que alimenta a "compulsão por maternidade", nas palavras de Rayna Rapp (2000), levaria à noção de que essas tecnologias estariam apenas amenizando o sofrimento de mulheres e casais.

Ainda nessa direção, outros estudos (Rohden, 2001; Tamanini, 2003, 2004; Martin, 2006) vêm demonstrando como, de maneira mais geral, a medicina tem se voltado mais sistematicamante para o corpo das mulheres, bem como o viés de gênero dessa construção. Embora o processo de medicalização alcance homens e mulheres e uma ciência voltada ao corpo dos homens venha se desenvolvendo (Azize, 2004) mesmo antes do boom do Viagra (Malcher, 2007), ao longo da pesquisa ressaltava-se como vem se dando uma maior naturalização das intervenções no corpo das mulheres.

Essa naturalização pode ser percebida na forma como as mulheres falam de certas intervenções no seu corpo e na forma como muitas delas se relacionam com o espaço do hospital e com os médicos e outros profissionais.

Em certo momento da pesquisa, eu me perguntava se seria possível que uma análise da forma como homens e mulheres submetidos ao controle biomédico na reprodução assistida apenas reafirmasse a replicação dessa trajetória feminina nos corpos dos homens. A partir de minha percepção de situações que evidenciavam a maior 'naturalização' das rotinas médicas por parte das mulheres, foi se configurando uma noção de que nuançar a percepção do lugar dos homens nesse contexto 
não implicava uma disputa. ${ }^{4}$ Parecia não haver vantagens a serem perseguidas por um e outro.

\section{Homens e mulheres na fila de espera}

Com o objetivo de tornar mais claras as questões mencionadas até aqui, apresentarei agora minha percepção dos lugares ocupados por homens e mulheres em suas trajetórias em busca de um filho. Esta percepção foi se construindo ao longo da pesquisa, mas vários elementos já estavam presentes desde os primeiros contatos com o serviço de reprodução assistida no hospital.

Chamava-me a atenção a cena da sala de espera, na consulta com a enfermeira, ou já no momento da fertilização no ambulatório, formada em geral de casais sentados lado a lado. Em outros momentos era possível acompanhar mulheres sozinhas na fila.

Em cinco dos 17 casais acompanhados via hospital, estava apenas a mulher no momento do tratamento. Nos doze restantes, estava presente o casal. Quando eu perguntava a essas mulheres desacompanhadas sobre seus maridos, invariavelmente a justificativa referia-se ao trabalho dos esposos. Para esses casais, a presença do homem se restringia aos dias de realização de algum exame, especialmente espermogramas, os exames de rotina solicitados pelo sistema de saúde e o dia da coleta do material, ou seja, a coleta do sêmen para a fertilização. Nos demais casos, os homens tendiam a acompanhar as mulheres independentemente dos procedimentos médicos a serem realizados.

A cena da entrega de potinhos com tampa vermelha na sala de fertilização, cuja porta fica em frente às cadeiras onde as pessoas esperam no ambulatório, sempre chamava a atenção e era, em geral, um momento de constrangimento. Os homens timidamente batem à porta, querendo esconder aquele pote, esperando que a enfermeira os venha atender. ${ }^{5}$

4 Ao contrário do que foi considerado em outros momentos a partir de minha inserção no debate feminista sobre a 'participação dos homens'. Ver Nascimento (2007a) para uma reflexão mais detalhada sobre as implicações da relação entre a prática de pesquisa e o ativismo no campo feminista, bem como uma espécie de autocrítica dessa discussão.

5 Não cheguei a acompanhar cenas descontraídas como a descrita por Charis Thompson (2005), em que um homem é saudado com aplausos por duas mulheres quando retorna da sala, pelo fato de ele ter conseguido 'coletar o material', diga-se, ejacular, tão rápido. Para essa discussão, ver também Luna $(2004,2007)$. 
A chegada com a caixa dos medicamentos necessários para a realização dos procedimentos a que as mulheres vão se submeter é igualmente característica. Por serem medicamentos que precisam de refrigeração, são mantidos em caixas de isopor, em geral, transportadas pelos homens.

\section{De quem é o problema? Uma primeira disputa}

"Qual é o teu problema?" Ouvi esta pergunta várias vezes, principalmente quando os casais se encontravam nas salas de espera. Em uma de minhas primeiras idas ao hospital, inadvertidamente, disse para uma mulher sentada na sala de espera que a minha pesquisa era sobre infertilidade e ela retrucou enfaticamente: "Olha, o problema da gente não é infertilidade. Pelo contrário, tem fertilidade até demais, mas é que meu marido fez vasectomia".

Uma outra mulher fez questão de deixar claro que seu marido não podia ter filhos "naturalmente" porque tinha feito quimioterapia. Esperando para ser atendida, Amanda, uma jovem de 30 anos, ao ouvir uma mulher dizer que o marido tinha baixa taxa de espermatozoides, segurou a mão dele orgulhosamente e disse: "O meu problema é diferente".

Marina, 46 anos, logo se colocou como sendo a "responsável" pela dificuldade de o casal ter um filho: "O médico disse que o exame dele estava ótimo, o problema é todo comigo".

Conseguir um diagnóstico claro sobre a causa da dificuldade para ter filhos é uma das principais questões dos casais em sua trajetória pelos serviços de saúde. Na maioria dos casos, a descoberta do diagnóstico leva muitos anos e, inúmeras vezes, o diagnóstico não é claro. Identificar quem é o problema, portanto, passa a ser uma questão central para os usuários do serviço de reprodução assistida. Não apenas no sentido de aplacar a angústia de não saber o que se tem de errado - o que é muito comum -, mas também no sentido de identificar as responsabilidades de cada um.

$\mathrm{Na}$ busca por identificar a participação de homens e mulheres em situações de dificuldade para engravidar, as informações veiculadas pelos médicos assumem importância. Embora estes profissionais divirjam acerca dos exatos percentuais, costuma-se afirmar que há a seguinte participação de mulheres e homens na definição de um quadro de infertilidade: 30\% homem, 30\% mulher, 30\% ambos, 10\% 'causa não identificada'. Outros falam em $40 \%$ para cada um do casal e $20 \%$ para causas 'desconhecidas'. 
No entanto, se levarmos em conta os resultados do levantamento de uma outra pesquisa realizada por Macedo e colaboradores (2007), podemos nos questionar sobre a validade dessa equação. Nesta pesquisa, $65,5 \%$ têm causas femininas; $17,9 \%$, masculinas e 10,3\%, ambos. Apesar das discrepâncias, a discussão sobre os percentuais continua sendo um elemento marcadamente presente na fala dos sujeitos.

Com relação aos casais acompanhados no hospital, quatro são apresentados pelos médicos como casos de causas exclusivamente masculinas, em que se incluem baixo número de espermatozoides ou espermatozoides com pouca mobilidade. Em cinco outros casais, há problemas com ambos os cônjuges. Nesses casos, incluem-se desde aqueles em que o homem tem baixo número de espermatozoides e a mulher tem 'causa desconhecida' ou ainda 'idade avançada'.

Com relação à identificação das causas, muitas feministas têm criticado a emergência da noção de casal infértil (Tamanini, 2003; Diniz \& Costa, 2006) como servindo para obscurecer casos em que o fator masculino é definitivo. Argumentam que, quando o problema é claramente feminino, não há hesitação em afirmar-se que a causa da não gravidez é um 'problema da mulher'. Quando o fator masculino emerge, dar-se-ia uma ampliação do problema, passando a ser visto como 'do casal'.

Sete outros casos são diagnosticados como de 'causas femininas'. Estão aí incluídos os casos de mulheres com obstrução tubária, endometriose e uma série de fatores presentes no perfil destacado por Rosana Barbosa $(1999,2003)$ para pensar aquelas situações em que mulheres, por não terem tido acesso a serviços médicos de qualidade ao longo de suas vidas, desenvolveram problemas ginecológicos que configuraram o quadro de infertilidade e poderiam ter sido evitados, se diagnosticados com antecedência. ${ }^{6}$

E, finalmente, um dos casais, embora tenham sido identificados cistos no ovário da mulher, não considera os esclarecimentos suficientes e se dizem incluídos no conjunto das causas desconhecidas. Há diferentes casos em que o diagnóstico médico é questionado e muitas vezes ouvi pessoas

6 Em outra investigação no mesmo hospital onde foi realizada essa pesquisa, os médicos relataram três causas principais da infertilidade: "obstruções tubárias por causa de infecções que a mulher teve no passado, associadas a doenças sexualmente transmissíveis como a clamídia e gonorreia"; a esterilização feminina e a faixa etária das mulheres que se submetem ao tratamento (Allebrandt \& Macedo, 2007: 20). 
dizerem que os médicos não sabem exatamente o que fazer e que o procedimento escolhido seria uma espécie de loteria.

\section{Corpos masculinos (também) medicalizados}

Analisei as questões colocadas por muitas pessoas com quem dialoguei não apenas em termos da atribuição da 'responsabilidade' de homens e mulheres, mas também como ambos têm participado desse processo. Minha intenção é refletir sobre as possibilidades de nuançar a forma como os homens aparecem para além de sua função ejaculatória, como aponta Charis Thompson (2005).

Para este fim é preciso considerar os contextos mais gerais onde essa busca por filho se dá, destacando-se aí o processo de medicalização da vida no qual os homens, e não apenas as mulheres, estão cada vez mais inseridos (Rosenfeld \& Faircloth, 2006).

Muitas vezes, ao longo da pesquisa, me chamava atenção a forma como algumas mulheres narravam as dificuldades e a resistência que seus companheiros apresentavam para a realização do espermograma. Isto se destacava principalmente porque quando me relatavam procedimentos percebidos por mim a princípio como mais invasivos, elas o faziam sugerindo uma certa 'naturalidade' desses procedimentos. Em alguns momentos, eu me questionava: seria possível estabelecer sempre uma escala da complexidade e do caráter invasivo dos procedimentos, ou haveria possibilidades de relativizar e contextualizar as dificuldades narradas pelos homens? Ou ainda me perguntava: as respostas para essas questões deveriam ser buscadas no tipo de relação estabelecido pelo casal ou deveria atentar para os condicionantes mais gerais do processo de medicalização da reprodução? À medida que a pesquisa avançava, passei a considerar que um posicionamento não inviabilizaria o outro. Ou seja, identificar agentes globais ou estruturais das especificidades dos dilemas vividos pelos casais não deveria obscurecer a consideração do nível micro e cotidiano de como essas relações se construíam.

Acompanhando as trajetórias dos casais no hospital, fui observando e ouvindo da parte de muitos deles que para se chegar a algum diagnóstico, por regra, a primeira investigação acontecia junto às mulheres. A 'porta de entrada' no hospital é o setor $F$, onde funciona o serviço de ginecologia. Mesmo que já conheçam os caminhos dos procedimentos a serem realizados e tenham uma recomendação direta de "tratamento para 
engravidar", os casais terão inevitavelmente de passar pelas consultas com os profissionais do serviço de ginecologia. São eles que, a partir de sua análise, vão encaminhar os casais para o setor de infertilidade do mesmo hospital. $^{7}$

De todos os casais contatados nessa etapa da pesquisa, apenas um deles, que havia realizado exames pré-nupciais, tinha conhecimento da ocorrência de 'baixa mobilidade' dos espermatozoides. Essa investigação, a partir de uma suspeita de um problema com a mulher, se estende até o hospital onde a pesquisa foi realizada. As consultas são feitas em nome da mulher no serviço de ginecologia e todas as vezes em que estive presente nos corredores do hospital, aguardando para ser apresentado aos casais, era sempre o nome da mulher que ouvia ser chamado. Ao se identificar, essa mulher era cumprimentada pela enfermeira e lhe apresentava ao companheiro.

Foi com estranhamento que Valdir, 37 anos, comentou que passou três meses acompanhando a esposa sem que a equipe médica lhe pedisse nenhum exame:

Quando a gente chegou lá no hospital também foi outra dificuldade porque tudo estava marcado lá no nome dela [a esposa] e eu dizia para os médicos: Mas o problema é comigo, é a mim que vocês têm que pedir os exames, e eles não diziam nada. Só diziam: Primeiro a gente tem que examinar ela, vamos ver o que tem com ela. Aí fizeram todos os exames nela e não descobriram nada. Três meses nessa. Aí depois de três meses, a gente perdendo tempo é que eles me chamam e veem tudo aquilo que a gente já sabia. (...) Foi então que eles pediram os exames e viram que tinha que congelar os espermatozoides. E fez logo, teve que fazer uma cirurgia... Eu queria logo que o que tivesse que fazer fosse feito $\operatorname{logo..}$

Após ouvir a narrativa dessa espera, continuei perguntando como tinha sido o procedimento médico com o objetivo de perceber como o casal tinha vivenciado essa experiência de investigação no corpo de Valdir. Eu não sabia que tinha que fazer uma cirurgia nesse caso e perguntei a Valdir como tinha sido. Valdir continuou explicando, empolgado:

7 Esse processo corresponde à rotina estabelecida pelo hospital e a uma dinâmica própria, certamente necessária ao funcionamento da instituição. Não se coloca em questão aqui a necessidade das rotinas, mas destaca-se a percepção da mesma e suas implicações para o tema em discussão. 
Teve que fazer cirurgia. Teve anestesia e tudo... Eu vi eles lá fazendo, tiraram um negócio amarelo parecido com gordura e levaram pra congelar... - E foi grande essa cirurgia? Não, não foi, diz Valdir. Mas sua esposa discorda, dizendo que foi grande. - Quantos pontos tu levaste? Ele diz: Uns dez.... E ela reafirma: Olha aí, foi grande. Valdir continua: Eu nunca tive medo de nada de médico, não. O que tiver que fazer eu faço. Tenho vontade de chegar lá num congresso de médico desses e dizer 'olha meu caso aqui', ir lá no quadro e mostrar [fazendo gesto de desenhar num quadro imaginário] 'aqui é um testículo, aqui é o outro, aqui é... [como se quisesse dizer pênis, me pareceu] o que falta é fazer essa ponte aqui'... para ver o que eles vão dizer. Ele ri muito de tudo isso que diz e eu acompanho também rindo. Valdir continua: Eu queria ser uma cobaia para eles descobrirem como resolver esse meu caso... Eu vou num congresso um dia desses, diz isso continuando a rir.

Esse casal vinha de uma trajetória de onze anos de busca por respostas. Por essa razão, dominava com muito mais desenvoltura os códigos da biomedicina, além do jeito desenvolto de Valdir, particularmente, facilitar sua narrativa. Dentre todos os casais que conheci, esse foi o que de forma mais explícita questionou o escrutínio a priori no corpo das mulheres, bem como reclamou uma maior investigação do chamado fator masculino na dificuldade do casal para ter filhos. Quando o ouvi falar "em tom de brincadeira" que queria ser uma cobaia na mão dos médicos, me ocorria não apenas um desejo marcante de ter seu 'problema' resolvido, mas uma confiança de que esses mesmos médicos encontrariam as respostas e a ciência era o caminho para isso - ele parecia querer pagar o preço com o próprio corpo. Essa crença apoiada na investigação e acompanhamento do que os médicos vinham realizando no corpo de Valdir permitia-lhe um maior domínio do que ocorria em seu tratamento, bem como os caminhos que ainda viriam a percorrer. Na conversa com outros casais, o que ressaltava eram a perplexidade diante das informações e o incômodo de se falar claramente sobre o que os médicos chamam de fator masculino na infertilidade.

Carina e Arthur tinham, respectivamente, 27 e 28 anos e moravam em uma cidade ao sul do estado, tendo de se deslocar na ambulância da prefeitura para consultas e exames. Perguntaram-me se poderíamos conversar ali mesmo no corredor do hospital, pois achavam que moravam em um bairro muito distante e difícil de encontrar. Em um primeiro momento da conversa, houve embaraço para que eles me dissessem que o 
'problema' era com o marido. Isto ficou claro quando eu perguntei o que a primeira médica que eles haviam consultado, ainda em sua cidade, teria apontado como problema. Carina corou, rindo e olhando para Arthur. Fez sinal com o dedo indicador apontando para ele. Arthur também riu e não falaram nada por segundos. Eu, achando que tinha perguntado algo indevido, indaguei se eles não queriam falar sobre o assunto e travou-se, então, o seguinte diálogo:

Carina: Não... é que a médica disse que [o problema] era com ele. Ela me examinou toda, fez todos os exames e estava tudo certo... Ele é que tinha muito pouco... (rindo).

Arthur: É... os exames deram taxa muito baixa... - De espermatozoides?, eu pergunto. Isso... Eu fiz o exame e ela disse que com aquela quantidade não dava...

Carina: É porque só depois desse tempo sem conseguir engravidar é que eles começam a fazer a investigação... Aí quando viram que não era comigo, começaram a investigar ele. Eles viram que tinham a taxa de prolactina muito alta... Estava 150 a dele, e a normal é 17. Eles chegaram a pensar que ele podia ter um tumor no cérebro...

Arthur: Algum problema na glândula...

Carina : (Olha e confirma balançando a cabeça). Aí eles pediram vários exames, mas viram depois que a taxa tinha melhorado...

Arthur: Quando eu fui ao primeiro médico, ele passou um monte de remédio e eles diziam que era para tomar e ver se aumentava a taxa.

Carina: Foi, tomou aquele Shoragon... - Shoragon não é aquele que as mulheres tomam para ovulação? Perguntei. Sim, é, mandaram ele tomar também...

Arthur: E uma vitamina...

Carina: Shoragon 5000 e vitamina $A, B$ e $C$.

Arthur: Aí eles viram que depois tinha aumentado.

Carina: Estava em 850 mil... Na primeira eles fizeram e estava zerada, a médica até se assustou... Na segunda também deu zerada, mas depois aumentou. 
Arthur: Isso tudo foi particular, era muito caro. Esse Shoragon eu tinha que tomar por seis meses, mas eu só tomei um mês. Cada caixa tinha três ampolas e custava 200 reais.

Carina: Ele tinha que fazer outro exame também, mas era particular, custava 400 reais esse exame, ele não fez... Eles [os médicos] queriam investigar porque eles queriam saber se era genético [a baixa produção de espermatozoides], mas ele não fez, não tinha como pagar mais 400 reais.

O momento inicial de constrangimento contrasta com a abertura de Valdir e Marisa, que vimos anteriormente. Mas, uma vez vencida a timidez desse momento, Carina e Arthur falam de como a investigação se deu com ela e só depois com ele e as formas intermediárias de tentativa de resolução que os médicos lhe sugeriram por medicamento. A identificação na trajetória de Arthur de baixa produção de espermatozoides, somada a uma alta taxa de prolactina e ao uso de medicamentos, a princípio prescritos para as mulheres, me faziam entender a dificuldade inicial de eles falarem comigo.

Em ambos os casos, a narrativa é marcada por um tempo longo em que um diagnóstico e um tratamento apropriados são buscados sem muito êxito. No caso de Arthur, foi logo identificado seu problema. O casal refere que os exames foram feitos sem resistência. Outros homens se recusaram a princípio a fazer o espermograma. Essa resistência inicial já foi apontada em outros trabalhos como significando para homens e mulheres ameaça à virilidade (Costa, 2001; Thompson, 2005). Além disso, é possível perceber nos casos seguintes, como foi dito para as situações descritas, que tanto a forma como é feito esse diagnóstico como os possíveis encaminhamentos são longos e muitas vezes incertos. Essas duas dimensões precisam ser levadas igualmente em conta.

Quando fui à casa de Luísa e Genival (26 e 30 anos, respectivamente) em um bairro da periferia de Porto Alegre e tentava entender no início da conversa qual era o tipo de problema que os havia feito procurar tratamento, Luísa falou diretamente: "Na verdade, eu não tenho problema nenhum, nos meus exames todos está tudo certo. Ele tem um problema que disseram que é o espermatozoide lento e também é baixa a quantidade, née." Luísa dá a deixa para o marido, Genival, que vinha quieto e tímido até o momento, falou: "É, pelos exames, tem uma taxa baixa dos espermatozoides". Após narrarem a trajetória de investigação, 
correspondendo à 'fase da busca' por uma explicação e tratamento (Nascimento, 2007b, 2009), eles começaram a apresentar elementos que mostravam a investigação feita para identificar o 'problema' de Genival, como foi para Arthur e Valdir. No entanto, Luísa fez questão de destacar a resistência inicial do marido:

Eu fui ao médico e ele disse que estava tudo bem comigo e eu ficava mandando Genival ir ao médico e ele não queria, ia adiando, não sei se preguiça ou vergonha, o que era... Mas aí, depois de uns dois anos, ele foi lá na Clínica Salute, que fica ali na Cavalhada [nome do bairro] e fez o exame e acusou que ele tinha esse negócio, do esperma baixo. Mas o médico disse que ele tinha que fazer um tratamento de dois meses, ele passou um remédio que ele ia tomar. - Para que era o remédio? [eu perguntei]. Era para aumentar o esperma. Ele disse que ele tomasse por dois meses que ia aumentar. Mas ele tomou e nada...

Genival me respondeu que fizera o espermograma. Perguntei, mencionando a fala da esposa sobre sua resistência para ir ao médico, quais teriam sido as razões para isso, e ele disse: "Ah, era mais vergonha mesmo... Eu ficava tímido, mas agora não me importo mais não". Luísa reconheceu a mudança no marido e reforçou: "É. Agora ele perdeu a vergonha mesmo. Ele teve que fazer lá no hospital e fez sem problema", e continuou:

O médico pediu o exame duas vezes e eu trazia o papel para ele ir fazer e ele não ia. Depois ele foi e fez esses dois e ainda fez mais três no hospital. E ainda fez uma ecografia também... Uma 'eco' no testículo porque eles queriam ver se tinha aumentado. Era assim, eles faziam um exame, passava o remédio, depois de um tempo, mandava fazer outro exame pra ver se tinha aumentado [o número de espermatozoides].

Assim, como aconteceu no caso de Arthur, outras pessoas relataram ser comum a prescrição de medicamentos, 'vitaminas' que poderiam repor o nível desejado da produção de espermatozoides, sem que saibam muito bem para que serviriam. Genival, Arthur e outros homens com quem conversei geralmente tratavam essas questões com constrangimento. A única variação nessa posição foi a de Valdir, parecendo sempre empolgado e rindo dos percalços enfrentados. O sentimento de vergonha e timidez é um dos mais recorrentes, e o uso de medicamentos é descrito como algo não corriqueiro, muito distante do que aparecia na fala e na rotina das mulheres. 
Ao mesmo tempo, entre os vários elementos que aparecem nessas falas, podemos ressaltar que a mesma resistência dos homens a fazerem os exames e a identificarem-se e serem identificados como 'inférteis' é marcada pelas mesmas dificuldades de acesso a um serviço capaz de lidar com essas dificuldades e buscas.

Fica difícil estabelecer com muito rigor onde um desses elementos se sobrepõe ao outro, mesmo nos casos em que a recusa a procurar o serviço de saúde é justificada por vergonha. Não apenas o acesso ao serviço apresenta constrangimentos para homens e mulheres, mas uma vez no processo de investigação e tratamento, é possível perceber uma estrutura de serviços médicos voltada ao corpo das mulheres e suas necessidades.

\section{Para além de anjos e demônios}

Após a exposição dessas trajetórias, podemos nos perguntar: como essas questões podem ser entendidas em relação ao que vem sendo debatido a respeito das NTCs? Muito tem se perguntado se essas tecnologias recolocam, superam ou modificam questões centrais no debate sobre reprodução e gênero? A discussão sobre infertilidade e concepção, mais do que aquela sobre fecundidade e contracepção, oferece outros caminhos para pensar o 'lugar dos homens' na reprodução e o próprio debate sobre paternidade?

Verena Stolcke (1986) e Françoise Heritier (2000), ao analisarem o desenvolvimento dessas tecnologias, se perguntam: qual a novidade das NTCs? Uma das mais recorrentes críticas e questionamentos é de que tais modificações não têm levado a uma redefinição do padrão de gênero assentado na subordinação das mulheres, principalmente por causa da medicalização de seus corpos e de uma espécie de retomada vigorosa da vinculação entre mulheres e maternidade. Uma perspectiva que em alguma medida partilha a visão, por exemplo, de Verena Stolcke, de que as NTR enquanto uma "nova forma de opressão" teriam como objetivo "dar ao marido um filho do seu próprio 'sangue"' (Stolcke, 1986: 21).

Embora diversa em seu conjunto, a obra Feminismo e Novas Tecnologias Reprodutivas, publicada em 2006, é marcada por essa perspectiva de resistências e oposição a essas tecnologias por considerarem seu caráter de reprodução da subordinação feminina. Nas palavras de uma das autoras, 
Esse desejo sem preço da maternidade pode estar atendendo ao desejo da paternidade, cuja realização afirma a fecundidade e exalta a virilidade, especialmente em regiões onde o machismo é acentuado. Em pesquisas sobre maternidade tem-se verificado que as mulheres referem-se, frequentemente, ao forte desejo de 'dar um filho para o seu homem'. Esse desejo seria mais forte do que o próprio desejo de maternidade? Nas NTCs, a resposta ao desejo de paternidade - não importando quem seja o estéril no casal heterossexual - incide no corpo feminino, questão política e de saúde da maior importância. (Scavone, 2006: 16)

O que estou fazendo ao recuperar esses posicionamentos é enfatizar mais uma vez que, embora concorde com a crítica à forma naturalizada de apresentar essas tecnologias como solução e reconheça a assimetria de gênero a perpassar os exemplos que estão sendo acompanhados, os caminhos que têm sido percebidos extrapolam as decisões no âmbito do casal.

Mathew Gutmann (2006) põe foco nos pressupostos implícitos na forma como tem sido conduzido o debate sobre a figura masculina nos estudos sobre reprodução. Para ele, embora as mulheres tenham sido 'desnaturalizadas' pela crítica feminista, muitas vezes continuam-se atribuindo categorias uniformes aos homens. Muitas vezes, também, a 'cultura' acaba sendo usada para manter e difundir estereótipos a respeito da saúde reprodutiva e da sexualidade masculinas. Ele nos lembra, a partir do exemplo do México, que esse uso simplista da cultura esteve presente na crença, trinta anos atrás, de que planejamento familiar não iria ser adotado pelas mulheres naquele país católico (Gutmann, 2006).

Buscar os significados dados por homens concretos para este processo permitirá entender a reconhecida penalização das mulheres como sendo mais que um resultado de uma atualização de conceitos pouco problematizados como dominação masculina e machismo, por exemplo. Margareth Arilha (2005), partilhando da ideia de Gutmann, demonstra que está em jogo a necessidade de superação da percepção do gênero e dos problemas enfrentados pelas mulheres como sendo definidos pela oposição homem/mulher e privado/público apenas.

Aqui, procurei mostrar como as noções do masculino e do feminino influenciam toda a procura do casal nas instituições médicas. Elas servem como definidoras de um longo percurso para o casal, onde vários outros elementos que extrapolam o âmbito conjugal também se apresentam. Sonia Corrêa, relembrando que a mudança individual de homens não levará às 
transformações esperadas nas relações entre homens e mulheres, afirma que essas mudanças demandariam

uma agenda de pesquisa e reflexão, mas, sobretudo uma agenda de coordenação política deveria ser ocupada internacionalmente e vinculada a um pensamento teórico e conceitual sobre gênero, em associação com as grandes questões econômicas. (apud Arilha, 2005: 163-164)

Assim, supor um olhar diferenciado para enxergar essas questões, bem como imaginar a possibilidade de inserção diferenciada dos homens no campo da reprodução e no debate sobre paternidade, demanda a superação da expectativa de que já se sabe o que esperar quando se inicia esse debate.

A crítica feminista ${ }^{8}$ alerta sobre os riscos de, sob a imagem de renovação, continuar-se a reproduzir estereótipos e a reforçar a desigualdade. Contudo, em muitas abordagens, continua a se operar com a expectativa de compartimentalização de universos masculino e feminino e um a priori de privilégio masculino.

Mais problemas ainda são trazidos quando essa noção da dominação masculina é tratada de forma indiferenciada, tanto para se referir aos casos de homens concretos em sua busca por filhos como para se falar do viés masculino dessas tecnologias e de uma noção de progresso científico enquanto incorporação dessa dominação. As falas dos homens que entrevistei remetem mais a dúvidas e inseguranças, vergonha e incerteza do que a uma noção de dominação masculina, ao menos quando estamos focando as relações de conjugalidade.

$\mathrm{O}$ olhar que percebe apenas as tecnologias como possibilitando às mulheres 'darem' filhos para 'seus homens' possivelmente não dará conta das disputas e das acusações que vimos para muitos casais. Para além dessa questão, em minha perspectiva, o foco central da análise da disseminação dessas tecnologias deveria ser mais a articulação entre ciência, medicina e mercado que naturalizam o desejo de filhos biológicos e apontam as NTCs como única via para a realização do desejo de filhos no idioma do mercado.

\footnotetext{
8 A referência ao movimento feminista como um todo ou à crítica feminista não quer negligenciar a complexidade desse campo onde há diferentes perspectivas e orientações. Para uma análise do feminismo em sua pluralidade no Brasil, ver, por exemplo, Bonetti (2007) e Adrião (2008).
} 


\section{Referências}

ADRIÃO, K. G. Encontros do Feminismo: uma análise do campo feminista brasileiro a partir das esferas do movimento, do governo e da academia, 2008. Tese de Doutorado, Florianópolis: Universidade Federal de Santa Catarina.

ALLEBRANDT, D. \& MACEDO, J. L. (Orgs.). Fabricando a Vida: implicações éticas, culturais e sociais das novas tecnologias reprodutivas. Porto Alegre: Metrópole, 2007.

ARILHA, M. O Masculino em Conferências e Programas das Nações Unidas: para uma crítica do discurso de gênero, 2004. Tese de Doutorado, São Paulo: Faculdade de Saúde Pública, Universidade de São Paulo.

AZIZE, R. L. Masculinidade, Viagra e saúde: um olhar antropológico. In: RIAL, C. \& TONELLI, J. (Orgs.). Genealogias do Silêncio: feminismo e gênero. Florianópolis: Mulheres, 2004.

BARBOSA, R. Desejo de Filhos e Infertilidade: um estudo sobre a reprodução assistida no Brasil, 1999. Tese de Doutorado, São Paulo: Departamento de Sociologia, Faculdade de Filosofia, Letras e Ciências Humanas, Universidade de São Paulo.

BARBOSA, R. Novas tecnologias reprodutivas conceptivas: produzindo classes distintas de mulheres? In: GROSSI, M.; PORTO, R. \& TAMANINI, M. (Orgs.). Novas Tecnologias Reprodutivas Conceptivas: questões e desafios. Brasília: Letras Livres, 2003.

BONETTI, A. Não Basta ser Mulher, Tem de Ter Coragem: uma etnografia sobre gênero, poder, ativismo feminino popular e o campo político feminista de Recife - PE, 2007. Tese de Doutorado, Campinas: Programa de Pós-Graduação em Ciências Sociais, Universidade Estadual de Campinas.

CORRÊA, M. Novas Tecnologias Reprodutivas. Limites da biologia ou bilogia sem limites? Rio de Janeiro. Eduerj, 2001.

CORREAA, M. Medicina reprodutiva e desejo de filhos. In: GROSSI, M.; PORTO, R. \& TAMANINI, M. (Orgs.). Novas Tecnologias Reprodutivas Conceptivas: questões e desafios. Brasília: Letras Livres, 2003.

COSTA, R. G. Concepção de Filhos, Concepções de Pai: algumas reflexões sobre reprodução e gênero, 2001. Tese de Doutorado, Campinas: Programa de PósGraduação em Ciências Sociais, Universidade Estadual de Campinas.

DINIZ, D. Introdução. In: DINIZ, D. \& BUGLIONE, S. (Eds.). Quem Pode ter Acesso às Tecnologias Reprodutivas: diferentes perspectivas do direito brasileiro. Brasília: Letras Livres, 2002.

DINIZ, D. \& COSTA, R. Infertilidade e Infecundidade: acesso às novas tecnologias conceptivas. In: FERREIRA, V.; ÁVILA, M. B. \& PORTELLA, A. P. (Orgs.). Feminismo e Novas Tecnologias Reprodutivas. Recife: Edições SOS Corpo, 2006. 
FRANKLIN, S. Embodied Progress: a cultural account of assisted conception. New York: Routledge, 1997.

GUTMANN, M. C. The missing gamete: men's place in the global female contraceptive culture. In: CONFERENCIA REPRODUCTION, GLOBALIZATION AND THE STATE, 1-7 jun. 2006, Bellagio. (Mimeo.)

HÉRITIER, F. A coxa de Júpiter: reflexões sobre os novos modos de procriação. Revista de Estudos Feministas, 8(1): 98-114, 2000.

INHORN, M. \& BALEN, F. van (Eds.). Infertility Around the Globe: new thinking on childlessness, gender, and reproductive technologies. Berkeley: University of California Press, 2002.

LUNA, N. Provetas e Clones: teorias da concepção, pessoa e parentesco nas novas tecnologias reprodutivas, 2004 Tese de Doutorado. 2004, Rio de Janeiro: Programa de Pós-Graduação em Antropologia Social, Museu Nacional.

LUNA, N. Provetas e Clones: uma antropologia das novas tecnologias reprodutivas. Rio de Janeiro: Editora Fiocruz, 2007.

MACEDO, J. L. de et al. Perfil dos usuários de um serviço público de reprodução assistida. In: ALLEBRANDT, D. \& MACEDO, J. (Orgs.). Fabricando a Vida: implicações éticas, culturais e sociais do uso de novas tecnologias reprodutivas. Porto Alegre: Metrópole, 2007.

MALCHER, L. Aos Cuidados de Príapo: impotência sexual masculina, medicalização e tecnologia do corpo na medicina do Brasil, 2007. Tese de Doutorado, Porto Alegre: Programa de Pós-Graduação em Antropologia Social, Universidade Federal do Rio Grande do Sul.

MARTIN, E. A Mulher no Corpo: uma análise cultural da reprodução. Rio de Janeiro: Garamond, 2006.

MOORE, H. Understanding sex and gender. In: INGOLD, T. (Ed.). Companion Encyclopedia of Anthropology. London: Routledge, 1997.

NASCIMENTO, P. Antropologia, feminismo e masculinidades ou o que os papudinhos de Camaragibe têm a ver com o debate sobre os homens no feminismo. In: BONETTI, A. \& FLEISCHER, S. (Orgs.). Entre Pesquisar e Militar: contribuições e limites dos trânsitos entre pesquisa e militância feministas. Brasília: Centro Feminista de Estudos e Assessoria, 2007a. Disponível em: <www.cfemea.org.br/ pdf/dossie_entre_pesquisar_militar.pdfp >. Acesso em: 26 abr. 2009.

NASCIMENTO, P. Pagando o preço: uma etnografia do acesso ao serviço público de reprodução assistida em Porto Alegre-RS. In: ALLEBRANDT, D. \& MACEDO, J. L. de (Orgs.). Fabricando a Vida: implicações éticas, culturais e sociais das novas tecnologias reprodutivas. Porto Alegre: Metrópole, 2007b.

NASCIMENTO, P. Reprodução, Desigualdade e Políticas Públicas de Saúde: uma etnografia da construção do 'desejo de filhos', 2009. Tese de Doutorado, Porto 
Alegre: Programa de Pós-Graduação em Antropologia Social, Universidade Federal do Rio Grande do Sul.

RAPP, R. Testing Women, Testing the Foetus: the social impact of amniocentesis in America. New York: Routledge, 2000.

ROHDEN, F. Uma Ciência da Diferença: sexo e gênero na medicina da mulher. Rio de Janeiro: Editora Fiocruz, 2001.

ROSENFELD, D. \& FAIRCLOTH, C. (Eds.). Medicalized Masculinities. Philadelphia: Temple University Press, 2006.

SCAVONE, L. Novas tecnologias conceptivas: teorias e políticas feministas. In: FERREIRA, V.; ÁVILA, M. B. \& PORTELLA, A. P. (Orgs.). Feminismo e Novas Tecnologias Reprodutivas. Recife: Edições SOS Corpo, 2006.

STOLCKE, V. New reproductive technologies: same old fatherhood. Critique of Anthropology, 6(3): 5-31, 1986.

TAMANINI, M. Do sexo cronometrado ao casal infértil. In: GROSSI, M.; PORTO, R. \& TAMANINI, M. (Orgs.). Novas Tecnologias Reprodutivas Conceptivas: questões e desafios. Brasília: Letras Livres, 2003.

TAMANINI, M. Novas tecnologias reprodutivas conceptivas: bioética e controvérsias. Revista Estudos Feministas, 12(1): 73-107,2004. Disponível em: $<$ www.scielo.br>. Acesso em: 25 ago. 2006.

THOMPSON, C. Making parents: the ontological choreography of reproductive technologies. London: MIT Press, 2005.

VARGAS, E. P. A figueira do inferno: os reveses da identidade feminina. Revista de Estudos Feministas, 7(1/2): 89-108, 1999. 


\title{
Representações da Violência de Gênero para Homens e Perspectivas para a Prevenção e Promoção da Saúde
}

\author{
Márcia Thereza Couto e Lilia Blima Schraiber
}

A violência de gênero no contexto das relações afetivo-conjugais é uma problemática geral, assumindo para alguns o caráter de 'universal', e que mobiliza pesquisadores no campo dos estudos de gênero e, mais recentemente, das masculinidades. Dialogando com essa produção, buscouse evidenciar e discutir o possível essencialismo que muitos atribuem ao caráter universal da problemática, a diversidade cultural brasileira e as conexões entre alguns de seus aspectos, a saber, as diferenças entre rural/ urbano e diferenças regionais do tipo Sudeste/Nordeste dessa violência de gênero.

Situações de agressão experimentadas por mulheres e homens são denominadas violência de gênero, pois se entende que essas situações se fundam na base socialmente construída das relações entre homens e mulheres a partir das diferenciações de poder que tais sujeitos detêm e exercem nas relações que estabelecem.

A discussão é pertinente ao campo das políticas de saúde voltadas à prevenção e à promoção, pela potencialidade de agregar elementos da diversidade de nomeações e sentidos regional e rural-urbana. Com isto, propostas e ações no campo dos estudos e políticas de combate à violência podem ganhar em efetividade quando culturalmente apropriadas às diferentes realidades sociais.

Desde a década de 1970, diferentes pesquisadores, vinculados ao movimento de mulheres e/ou à academia, lançam-se na busca de entender os riscos diferenciados para homens e mulheres de agredirem e serem agredidos, assim como as possibilidades de acessar recursos, igualmente diferenciados, para enfrentar estes riscos (Heise, Ellsberg \& Gottemoeller, 
1999). A temática da violência contra a mulher foi trazida à cena política e ao debate acadêmico brasileiro na segunda metade dos anos 70, inscrevendose no campo da saúde mais expressivamente a partir dos anos 90. Estabelecese como forma de denúncia da magnitude e invisibilidade social de atos violentos que têm, como espaço preferencial, o privado e, como protagonistas, homens-agressores e mulheres-agredidas em relações de intimidade/conjugalidade (Schraiber, Gomes \& Couto, 2005; Saffioti \& Almeida, 1995).

De modo articulado ao incremento dos estudos empíricos, observam-se mudanças e ampliação nas abordagens e referenciais de análise da temática. Assim, se, na década de 1980, a violência contra a mulher era analisada como fenômeno resultante do 'phalluscentrismo' ou do patriarcalismo; na década seguinte a crítica a este tipo de análise volta-se ao debate acerca da essencialização da discussão sobre violência em uma dualidade entre vítima e algoz (Gregori, 2003). Com a crescente incorporação da perspectiva relacional de gênero, os estudos se voltam, a partir dos anos 2000, para os diferenciais entre os gêneros que respondem, fundamentalmente, aos posicionamentos dos sujeitos na sociedade, segundo classe, raça, etnia, geração, entre outros, e ao modo como os sujeitos vivenciam as relações sociais com o mesmo sexo e com o sexo oposto nos domínios público e privado (Couto \& Schraiber, 2005).

Embora a produção acadêmica brasileira acerca da temática violência contra a mulher se mostre crescente, na saúde, desde os anos 90 (Schraiber, d'Oliveira \& Couto, 2006), é apenas na segunda metade da década de 2000 que os homens, como sujeitos implicados nas relações violentas, passam a merecer considerações não apenas como agressores mas também como sujeitos das pesquisas. Seguindo a tendência de investigações internacionais, a face masculina começa a ganhar destaque quando as experiências de ações políticas interventivas no campo jurídico e da saúde apontam que o trabalho com as mulheres necessitam da inclusão dos homens para barrar o ciclo de violência entre os gêneros (Greig, 2001).

O deslocamento quanto ao foco até então preferencial das análises (as mulheres) deve ser creditado, também, à consolidação da abordagem de gênero e ao incremento dos estudos sobre masculinidades. Pesquisas recentes sobre a violência conjugal e a violência de gênero a partir das representações e discursos masculinos apontam que, para os homens, embora a violência seja em princípio sempre condenável, é justificada a partir de um processo de naturalização da identidade social masculina. Neste processo de 
naturalização do social, categorias como 'instinto', 'impulsividade', 'fatalidade' e 'destino' são adotadas para dar sentido às agressões perpetradas contra as esposas-companheiras (Couto et al., 2007), o que, consequentemente, ajuda a encobrir a identificação dessas ações como violência (Rosa et al., 2008).

As análises também creditam as irrupções de situações de violência às recentes mudanças socioculturais e seus efeitos perversos nos valores morais dos homens assentados em uma rígida divisão e hierarquização de papéis para homens e mulheres na sociedade (Alves \& Diniz, 2005; Gomes \& Freire, 2005). A quebra nas relações de reciprocidade entre os gêneros, nas quais caberia ao homem prover material e moralmente a família, ao passo que às mulheres responder às necessidades de cuidado da casa e dos filhos, bem como subordinar sua sexualidade ao controle masculino, estaria colocando em xeque a autoridade masculina. Como decorrência deste processo, o exercício da violência seria a busca de (re)colocar no lugar da ordem o que os homens consideram como desordem em seus relacionamentos e em suas famílias. Toma-se esta explicação como uma das que se adota relativamente à violência de gênero, sem, contudo, anular a que remete à atribuição de 'educador' assumida pelo homem, mediante a qual este se vale da violência para ensinar à mulher seu lugar social, mesmo sem ter havido ruptura da ordem hierárquica prevista (Schraiber, d' Oliveira \& Couto, 2009).

A partir deste quadro, focaliza-se o fenômeno da violência de homens contra mulheres em uma perspectiva relacional-estrutural de gênero (DantasBerger \& Giffin, 2005), o que implica contemplar análises sobre os processos de socialização masculina e os significados de ser homem na sociedade, articulando-os ao concreto-vivido das condições de existência que forma a base para a experiência das relações afetivo-conjugais.

Com isto, lança-se mão dos aspectos simbólicos que conformam a socialização masculina assentada em uma busca constante de coibir emoções e negar sentimentos (Da Matta, 1997), creditar à sexualidade uma ordem instintiva que impele à conquista sexual e banaliza a infidelidade (Gomes, 2008) e justifica o uso da violência e a agressividade em situações de teste da masculinidade (Nolasco, 2001). É, a partir de tal estruturação simbólica, que se analisam os contextos sociais de transformação, especialmente no campo da família e do trabalho, que reposicionaram homens e mulheres nas esferas pública e privada.

A perspectiva de análise adotada também se mostra adequada relativamente à possibilidade de se considerar de que modo padrões culturais 
(urbano-rural) e regionais (Sudeste-Nordeste) influenciam as representações de família, homem-mulher e conjugalidade e como estas contribuem para a conformação do simbolismo da violência nas relações afetivo-conjugais. Em suma, proporciona uma inteligibilidade maior às situações de violência vividas em contextos sociais e culturais diversos. Trata-se, portanto, de um recorte dirigido às diferenças. Isto não significa, entretanto, que se deixa de conceber a permanência do fenômeno violência contra as mulheres como norma aceita socialmente de modo mais geral, dada a adoção do referencial de gênero assentado nas premissas do poder e da desigualdade geral entre homens e mulheres. Entende-se que a violência de gênero é (re)produzida sob o pano de fundo de padrões culturais que surgem de processos convergentes de crescimento, mudança ou desenvolvimento. Tomando a prerrogativa dos estudos culturais, compreende-se que "assim, como a mudança só pode ser vista em contraste com a estabilidade ou manutenção cultural, a estabilidade só pode ser compreendida em contraste com a mudança" (Kaplan \& Manners, 1981: 19).

\section{Aspectos metodológicos}

O presente trabalho se inspira e utiliza dados de uma pesquisa mais ampla. Trata-se de estudo multicêntrico internacional - "WHO multicountry study on women's health and domestic violence against women" (Schraiber et al., 2002) - que conjugou coleta de dados qualitativos (entrevistas tipo história de vida com mulheres que sofreram violência, grupos focais com homens e mulheres, entrevistas semiestruturadas com informantes-chave/serviços de apoio e assistência a mulheres em situação de violência) e quantitativos (questionários domiciliares aplicados à amostra representativa de mulheres do município de São Paulo e de outros 13 municípios da Zona da Mata de Pernambuco).

Em particular, utilizamos aqui os dois grupos focais com homens de baixa escolaridade e rendimento realizados em São Paulo e os dois grupos focais com homens rurais (um do município de Tamandaré ${ }^{1}$ e um do

\footnotetext{
Tamandaré situa-se na Mata Meridional, distante $92 \mathrm{~km}$ de Recife, está entre os quatro municípios menos populosos (cerca de 20.500 habitantes) e apresenta uma das menores taxas de urbanização da Zona da Mata Sul. Em termos de atividade econômica, caracterizase por ser uma área de transição dos engenhos para a agricultura familiar em assentamentos do Instituto Nacional de Colonização e Reforma Agrária (Incra). Seu núcleo urbano é voltado para o turismo e o pequeno comércio.
} 
município de Carpina $^{2}$ ) de Pernambuco. Tal recorte deveu-se à opção de trabalhar a diferença regional (Sudeste/Nordeste) e cultural-geográfica (urbano/rural), na busca de analisar a existência de padrões diferenciados de masculinidade que dão suporte aos valores e atitudes na vida cotidiana dos homens, e como tais padrões fundamentam suas representações acerca das relações afetivo-conjugais, especialmente quanto aos conflitos e violência.

Em São Paulo, a pesquisa recorreu à terceirização da etapa de recrutamento dos participantes dos grupos focais com a contratação de uma agência especializada em pesquisa de mercado. A partir da definição dos critérios de seleção (sexo, idade e escolaridade), a empresa fez a seleção dos participantes. A realização dos grupos aconteceu nas dependências do Departamento de Medicina Preventiva da Faculdade de Medicina da Universidade de São Paulo (FMUSP). Os grupos focais com homens de baixa escolaridade, aqui analisados, foram moderados e observados por pesquisadores do sexo masculino que faziam parte da equipe paulista do projeto.

Em Pernambuco, por se tratarem de grupos focais com homens de áreas rurais, a logística foi mais complexa. A organização não governamental (ONG) parceira da pesquisa, SOS Corpo: gênero e cidadania, realizou contatos com os municípios. Em Carpina, recorreu à Federação dos Trabalhadores na Agricultura de Pernambuco (Fetape), cuja assessora indicou o presidente do Sindicato dos Trabalhadores Rurais. No contato com o presidente do sindicato, foi selecionada a comunidade de CarnaúbaTorta, ${ }^{3}$ distante 45 minutos de carro da sede do município, para a realização do grupo. O recrutamento de sujeitos foi feito nas ruas. $\mathrm{O}$ grupo foi realizado em escola municipal da comunidade.

No outro município, Tamandaré, o contato também foi feito com o secretário do sindicato. Selecionado o engenho Brejo, realizou-se o convite à participação. $\mathrm{O}$ grupo focal foi realizado na escola do engenho. Em ambos os locais, os grupos foram moderados e observados por

2 Carpina localiza-se na Mata Setentrional, encontra-se a $55 \mathrm{~km}$ de Recife, está entre os quatro municípios mais populosos de toda a Zona da Mata (cerca de 74.000 habitantes) e tem a maior taxa de urbanização da região. A atividade econômica sustenta-se basicamente do comércio, e sua pequena área rural sobrevive da agricultura familiar e da criação de frangos para abate..

3 Essa comunidade é formada por uns poucos arruados, que são conjuntos de casas unidas por meia-parede. O acesso a ela é feito por estrada de terra. 
pesquisadores do sexo masculino, membros do grupo de pesquisa de Pernambuco.

Utilizou-se o mesmo roteiro para ambos os estados, visando à análise comparativa posterior. Seu foco consistia na abordagem do problema violência nas relações afetivo-conjugais. Foi estruturado em cinco blocos em que se enfatizaram os seguintes aspectos: 1) a construção das imagens ideais de mulheres e homens; 2 ) as relações afetivo-familiares entre homens e mulheres; 3) a ocorrência, aceitabilidade, visibilidade da violência; 4) a discussão sobre os valores do senso comum sobre a violência por meio dos significados dados a ditos populares e, por fim, 5) as perspectivas de mudança e resistência em torno da questão da violência, explorada na forma de conselhos para filhos.

Para a análise do material visando a este trabalho, realizou-se um recorte segundo os temas abordados nos grupos focais a partir dos seguintes tópicos: o homem e a mulher ideais, as relações entre homens e mulheres; e os significados associados a ditos populares sobre relações afetivoconjugais e a violência contra a mulher.

Os dados provenientes das seções dos grupos focais foram analisados, considerando os seguintes procedimentos: 1) leitura exaustiva da transcrição de cada grupo focal e dos relatórios produzidos pelos observadores dos grupos; 2) estabelecimento de categorias temáticas; 3) organização e análise do material segundo as categorias temáticas por estado e, na sequência, de forma comparativa entre estes; 4) cotejamento dos conteúdos das categorias com a literatura sobre a temática geral e com as referências teóricas que norteiam a pesquisa.

\section{Caracterização geral dos sujeitos}

Os grupos focais de São Paulo contaram, ao todo, com a participação de 17 homens de classes populares com idade média em torno de 31 anos. A maioria era composta de trabalhadores em ocupações de baixa remuneração, ${ }_{1}^{4}$ com média de rendimento familiar de $\mathrm{R} \$ 546,00 .{ }^{5}$ Em relação à escolaridade, a maior parte dos homens tinha ensino fundamental incompleto (média de 7 anos de estudo). No que diz respeito à situação

\footnotetext{
4 As ocupações foram: segurança, vigilante, corretor de seguros, auxiliar da promotoria, vendedor, auxiliar administrativo, motociclista, auxiliar de mecânico, contínuo, ajudante geral, supervisor de manutenção, auxiliar de almoxarifado, ourives e fiscal de roteiro.

5 O salário mínimo à época da pesquisa era $\mathrm{R} \$ 200,00$.
} 
familiar e conjugal dos participantes, cabe ressaltar que, em São Paulo, a maioria era casada ou coabitava com a companheira, com média de 1,2 filhos.

Analisando os mesmos dados sociodemográficos dos 26 participantes dos grupos focais rurais em Pernambuco (10 em Carpina e 16 em Tamandaré), tem-se que a idade média também foi de 31 anos. Todos os homens trabalhavam com agricultura, a maioria como empregados de engenhos de cana-de-açúcar, sendo que alguns também plantavam culturas de subsistência em terras cedidas. A renda média era de $\mathrm{R} \$ 390,00$. A média de anos de escolaridade encontrada neste grupo foi de quatro anos. Já em termos de constituição familiar, a maioria era casada com média de dois filhos.

Vê-se, portanto, que, na caracterização sociofamiliar, diferenças culturais, especialmente ligadas à escolaridade, ocupação e rendimentos já se fazem presentes.

A partir dos temas que serão abordados, tratar-se-á de discutir como se processa a estruturação de aspectos recorrentes nos padrões de masculinidade (e não de uma masculinidade hegemônica) e como se configuram as tensões no processo de atualização destes padrões pelos homens rurais e urbanos, em Pernambuco e em São Paulo.

\section{Construindo a mulher e o homem ideais}

Recorremos aos discursos produzidos pelos homens de São Paulo e da Zona da Mata de Pernambuco acerca da mulher ideal e do homem ideal $^{6}$ o que nos permitiu vislumbrar características que informam os referenciais de masculinidades segundo a diversidade regional - Sudeste/ Nordeste - e urbano/rural.

Começando pelos grupos focais de São Paulo, os homens utilizaram como parâmetros a referência dos próprios relacionamentos (atuais ou anteriores) e imagens femininas que circulam na mídia e que, segundo eles, representam o padrão de beleza nacional. Em relação às suas mulheres, a inteligência, a maturidade, a responsabilidade foram as características mais valorizadas e ressaltadas como ideais. Já quanto às outras, os critérios de beleza física e sensualidade que se reúnem em personagens inacessíveis (atrizes, dançarinas e modelos em destaque na mídia) foram as referências. Um deles construiu, segundo tais referências, a mulher ideal: "1,60 m, 59 quilos, bunda bem feitinha... Mulher sem bunda para mim não tem graça".

6 Para construir as imagens do homem e da mulher ideais, os moderadores dos grupos focais suscitaram nos homens referências femininas e masculinas imaginárias e concretas. 
Entre os homens da Zona da Mata de Pernambuco, as referências morais sobressaíram em relação às características físicas. Ressalta-se que nenhuma figura feminina de exposição na mídia foi citada. Quando destacavam atributos físicos, os principais eram: bonita, gostosa, seios pequenos, pernas grossas, tornozelos cheios. Também mereceram destaque, na fala de alguns homens de Tamandaré, atributos de sensualidade e energia sexual. Um deles pontuou: "Eu gosto de mulher acesa, fogosa; tem que ter aquelas coxonas, mulher que você pode passar o inverno só com a carne".

Mas, sem dúvida, as duas principais características da mulher ideal para os homens pernambucanos foram: respeito e valor. Um deles destacou: "A mulher ideal é aquela que sabe se dá valor. Eu num quero é procurar uma pessoa que eu sei que tem bastante relação com todas as pessoas para ser minha esposa, porque ela transou com um, transou com outro".

Neste relato, sobressai a valorização da virgindade como marca da mulher ideal, aspecto esse que não apareceu nas falas dos homens paulistas. Entretanto, o tema virgindade não foi unânime entre os homens dos grupos focais em Pernambuco, especialmente em Carpina. Um participante relativizou a virgindade como critério marcador de mulher ideal: "Acho que esse negócio de virgem não tá tendo tanta importância... Pra mim depende se eu gostar. Se eu gostar de uma pessoa e ela for virgem muito bem, se não for.... aí vai depender do comportamento dela".

Note-se, contudo, que, se a virgindade é relativizada, o padrão de comportamento sexual associado à moral exigida pela sociedade ainda se constitui como eixo de referência de mulher ideal, dado também encontrado na pesquisa de Portella e colaboradores (2004).

Ainda quanto ao mesmo tema, os homens de São Paulo destacaram um ideal que tem, na emancipação feminina, um traço importante; o que não se verificou entre os pernambucanos dos dois municípios da Zona da Mata. Para muitos de São Paulo, mulher ideal deve ser "inteligente, dinâmica, arrojada", sendo desprezada aquela que não trabalha e, portanto, depende do homem.

Portella e colaboradores (2004) apontam que, especialmente entre os homens participantes da pesquisa em São Paulo, a referência à 'ajuda' feminina no tocante às despesas da casa passa a se configurar como um arranjo conjugal desejável e justo.

No entanto, percebeu-se contradição na exposição dessas ideias: ao mesmo tempo que se ressalta a necessidade do respeito, da amizade e 
do diálogo, abre-se um debate no qual o argumento central é a importância da mulher como objeto sexual e em que excesso de inteligência e/ou beleza feminina pode se transformar em problema.

Acho que uma mulher muito inteligente dá muito problema, porque ela não aceita as coisas.

Se puder juntar beleza e inteligência, aí sim, é a mulher ideal.

$\mathrm{O}$ assunto 'sexo' emerge no debate, evidenciando o conflito entre a priorização da emancipação feminina e a passividade sexual e os atributos físicos, características da mulher ideal. Quando o tema da satisfação sexual masculina entrou em pauta, a tensão entre os dois ideais distintos de mulher tornou-se aguda entre os homens paulistas. As características físicas substituíram o caráter como referência primeira da mulher ideal. Um dos participantes de São Paulo resumiu bem tal percepção: "Os homens dizem: mulher ideal é aquela arrojada, independente, compreensiva... mas no fundo, no fundo, a ideal, e a que todo mundo quer, é aquela que é objeto sexual dele. Ninguém tá falando, mas é verdade, todo mundo pensa isso."

Mais uma vez, a diversidade cultural e a regional potencializam diferenciações na conformação de ideais de mulher presente nos imaginários masculinos. Embora reconheçamos traços comuns que perpassam os dois grupos, é inegável que padrões, valores e atributos distintos geram a riqueza de referenciais cultural e regionalmente localizados de masculinidade.

Passando à construção do homem ideal, dois aspectos iniciais devem ser sublinhados. O primeiro é o fato de os homens terem sido bem mais 'econômicos' nas discussões sobre o homem ideal, quando comparados aos debates suscitados no tópico mulher ideal. $\mathrm{O}$ segundo foi que, também diferentemente da discussão sobre a mulher ideal, a construção do homem ideal tomou como base uma leitura de 'segunda mão', o ponto de vista do 'outro', a mulher. Em outras palavras, na descrição dos atributos ideais dos homens, a principal referência adotada foi a feminina e não a deles mesmos.

Este homem foi construído a partir do referente que eles julgam como sendo o das mulheres, como aquele que 'ajuda' em casa, é prestativo, dedica-se à família, é gentil, carinhoso, romântico, delicado ("mas não

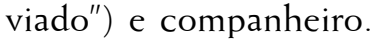

As frases de um participante paulista e de um pernambucano, respectivamente, apontam para isto: 
Eu acho que as mulheres gostam de homem romântico, que saiba fazer ela enlouquecer.

Eu acho que o homem ideal da mulher é um cara gentil, que sabe tratar bem, que gosta de ajudar... Eu também sou assim. Uma pessoa não agressiva. Tem que ser gentil, mas não viado.

Este ideal é construído em oposição àquele do homem agressivo, que bebe, usa drogas e bate na mulher. A violência, tema central dos grupos focais, entrou espontaneamente no debate em ambos os lugares (Pernambuco e São Paulo), e alguns casos pessoais foram, inclusive, relatados.

Se em relação à mulher ideal foi possível traçar um perfil mais unificado (porque polarizado entre a mulher dos atributos físicos e a mulher dos atributos morais); no que diz respeito ao homem os participantes revelaram dificuldade em sintetizar características que definissem um ideal. Ou porque se mostraram resistentes a qualquer proposta de elaboração de um ideal de homem, o que ocorreu mais fortemente em São Paulo, ou porque apontam para a dificuldade de eleger características mais ou menos recorrentes, por perceberem que há tantos tipos ideais de homens, quanto há fantasias e referenciais das mulheres. Um dos homens de São Paulo comentou: "É difícil dizer um único homem ideal para uma mulher. Porque cada uma tem um gosto, umas já gostam de um cara carinhoso, outras de um mais machão... outras gostam de malandro".

Apenas nos grupos focais da Zona da Mata de Pernambuco, os homens falaram sobre qualidades masculinas de maneira independente das referências projetadas para as mulheres. As virtudes enunciadas remeteram fortemente ao caráter e à moral do homem (Portella et al., 2004), como responsável pela família (Sarti, 1996), trabalhador e companheiro de outros homens (Nascimento, 1999). Ter moral, ser honesto, respeitador, trabalhador são, portanto, características essenciais do homem que cada um deve perseguir.

O homem tem que ter moral. Ter moral tem haver para toda vida.

Tem que considerar logo as famílias alheia e os próprios amigos, que é o que interessa. 


\section{Relações entre homens e mulheres}

Em primeiro lugar, 'sexo' foi o aspecto que abriu a discussão sobre as relações entre homens e mulheres nos dois grupos focais em São Paulo. ${ }^{7}$ Embora tal referência também tenha emergido espontaneamente nos grupos focais rurais de Pernambuco, tal ênfase foi mais forte em São Paulo.

Mas o sexo apareceu não apenas como fazendo parte de relacionamentos esporádicos, sem afetividade e vínculo. Em São Paulo, após a fala inicial taxativa que alça sexo a um primeiro plano, os homens reformularam esta referência e relativizaram-na em termos de que sexo não seria tudo, apenas um dos muitos aspectos dos relacionamentos entre homens e mulheres. Este conteúdo relativista e plural foi, para os participantes de Carpina e Tamandaré, logo de início abordado, quando um dos pernambucanos disse: "Relação entre homem e mulher tem que ter carinho, porque não há quem possa viver isolado".

Outras referências, além do sexo, como o companheirismo, a amizade, o respeito, a compreensão e a convivência foram citadas por todos os grupos, embora vez por outra sexo nas relações voltasse ao centro da discussão.

Os homens paulistas argumentaram que é da natureza masculina precisar de sexo, e a sua satisfação sexual representa um item importante para a estabilidade da relação, corroborando outros achados da literatura (Nascimento, 1999). Quando este falta, pela recusa da mulher/companheira, o homem passa a buscá-lo fora, o que se justifica pela "necessidade de uma satisfação física". Está posto, pois, a ideia arraigada de que sexo se constitui como um dos pilares da afirmação da identidade masculina. O relato a seguir ilustra bem esta percepção:

Quando o cara tá namorando, noivando, tem uma relação [sexual] mais contínua, pelo menos umas três vezes por semana. Mas, depois que casa, não. Fica 15, 20 dias... até um mês. Ela tá com dor de cabeça, tá com isso, tá com aquilo. Aí pinta uma briguinha. Porque você aí chega na sua mulher e ela recusa... você toca e ela se afasta, então é terrível você sentir que ela se afasta. Aí você começa a procurar pessoas por fora, paqueras, para ver se pinta alguma coisa... Tentando alimentar seu ego.

7 Nessa parte do grupo focal, a proposição dos moderadores foi: o que vem à cabeça de vocês quando falamos das relações entre homens e mulheres? 
Se sexo se configura como preeminente na relação afetiva, sua vivência não satisfatória traz riscos - a traição - que também foi constantemente relatada.

Entre os paulistas, a traição masculina foi a única comentada. As relações extraconjugais, que são exemplares quanto à quebra do padrão de reciprocidade estabelecido nas relações afetivo-sexuais, foram consideradas, pelos homens de São Paulo, como experiências preponderantemente masculinas. Um deles disparou: "Graças a Deus eu nunca fui traído, nem por namorada e nem pela minha mulher... mas já aconteceu de eu trair".

A traição por parte da mulher, como se percebe no relato, é algo que este homem não vislumbra para si, ao mesmo tempo que refere como usual no comportamento dos homens.

Embora tenhamos relatos de traição masculina apenas em São Paulo, estas situações são apontadas como podendo interferir no casamento (que, em muitas falas, aparece como um valor importante). Este, para ser mantido, depende de muita "luta". O matrimônio constitui-se para a maioria na referência primária para se pensar a relação entre homens e mulheres. ${ }^{8}$ No relato a seguir, também de um homem de São Paulo, o caráter relacional que está implícito (e explícito) na relação homem-mulher exige o reconhecimento do 'outro' (no caso, a mulher). Instaura-se, pois, a tensão entre a vivência de um modelo de masculinidade que pressupõe uma sexualidade livre e autônoma (Gomes, 2008), porque tem apenas como referente o homem que deseja, procura e obtém prazer, e o modelo de uma sexualidade compartilhada, em que autonomia, desejo e prazer são, também, considerados como atributos femininos.

Eu já tive relação extraconjugal. Não foi bom. Quase acabou meu casamento. $O$ que eu entendo é que a gente tem que lutar muito para manter o casamento. (...) Eu era mais novo e queria me afirmar como homem... Ter várias. Aí, quando minha mulher ficou sabendo, saíram todas fora... e ela também. E eu tive que ir atrás de minha mulher. Se é difícil dar conta de uma mulher, imagina de duas.

Já na Zona da Mata de Pernambuco, a traição feminina apareceu e mereceu, de saída, uma proposição: "Acho que acontece [traição] mais

8 Leve-se em conta que a maior parte dos participantes desses grupos era casada ou já havia sido por pelo menos um ano, como requisitado na própria convocação para a realização dos grupos focais. 
quando a mulher num... acho que quando num sente prazer, né, aí ela fica, fica procurando 'conhecer' homem. Olha, tem muita coisa nesse mundo".

Ainda nos grupos rurais, a referência à traição nas relações de casal aparece no discurso evangélico: "o crente tem que ser caseiro, ele e a esposa dele. Num pode ter um adultério".

Um outro aspecto que remete diretamente à vivência da sexualidade e à relação conjugal - a liberdade - emergiu da discussão no bloco das relações entre homens e mulheres, mas só em São Paulo. Explorar-se-á um pouco esta questão porque denota, ao menos, um discurso de transição de um padrão de masculinidade tradicional para um mais igualitário neste contexto urbano, que se mostra exemplar na discussão entre masculinidades e diversidade cultural.

Os homens dos grupos focais em São Paulo, mesmo reconhecendo que os impulsos sexuais são fortes e, quando não regulados, trazem conflitos aos relacionamentos, não deixam de mencionar que a liberdade é também um dado importante na relação afetivo-conjugal. A liberdade foi colocada como ponto fundamental para manter a relação e, principalmente, para a sua durabilidade. É verdade que a discussão da liberdade se iniciou pelo lado masculino. Alguns comentaram que as mulheres deveriam confiar nos seus companheiros e não se incomodar com as saídas com amigos. Mas, durante o debate, alguns colocaram que a liberdade não deveria ser algo exclusivo dos homens, mas também das mulheres.

Instaura-se, portanto, um deslocamento entre o padrão tradicional de controle do comportamento das mulheres (saídas com amigas, amizade no trabalho, estudos etc.) para um tipo mais igualitário no qual a liberdade é elemento constituinte da autonomia do sujeito e necessário no contexto das relações afetivo-conjugais.

Mas, pelo que se pode sentir ao longo do debate entre os homens dos grupos de São Paulo, a liberdade para as mulheres se localiza muito mais em termos do discurso genérico, não se apresentando como algo concreto ou que faz parte do cotidiano da relação. Há, portanto, uma ambiguidade no que é considerado como liberdade para homens e para mulheres. Se, para os primeiros, ela está associada à vivência/circulação irrestrita no espaço público (a farra com amigos no bar sem o olhar vigilante das companheiras, as amizades no trabalho etc.); para as mulheres, a liberdade foi referida de duas formas: como autonomia e independência em relação ao homem (poder trabalhar fora, estudar) e como autonomia e poder de decisão na esfera doméstica. 
Resumindo, a liberdade masculina se conecta com a necessidade de certa permissividade por parte da mulher em relação aos hábitos tradicionais masculinos (farra com amigos, chegar tarde em casa, não dar "satisfação de todos os passos"), que é responsável pela estabilidade da relação. ${ }^{9}$ Ao mesmo tempo, nos relatos de alguns homens paulistas, sobressai a ideia de que a mulher deve ser cuidadosa ao procurar diversão quando desacompanhada.

Vê-se, portanto, o caráter ambíguo e hierárquico presente no discurso sobre liberdade: mesmo que a dependência e a submissão da mulher ao homem apareçam de forma negativa $;$ a liberdade se localiza em um espaço que não deixa de ser restrito (a casa). Portanto, a 'natureza' diferencia, mais uma vez, homens e mulheres: enquanto a liberdade masculina deve ser irrestrita e está associada à diversão e ao espaço público, a da mulher está mais associada ao espaço da casa e, quando remetida ao público, trata-se apenas de trabalho e estudo, nunca lazer/diversão.

A análise deste bloco apontou para uma interessante problemática: a confluência e, ao mesmo tempo, a tensão, entre dois ideais de feminilidade: aquele que traz a referência da autonomia, liberdade e poder feminino conquistado ao longo das três últimas décadas e resultado das transformações socioculturais em torno da inserção da mulher no espaço público (ingresso no mercado de trabalho, maiores níveis de escolaridade etc.), e, por outro lado, o recurso à tradição, sobretudo familiar, que destina à mulher a reprodução dos usuais papéis de cuidado da casa e da família. Também fica claro que, entre os paulistas, a polarização entre esses ideais é mais equitativo, ou seja, embora o discurso que remete ao peso da tradição ainda se faça presente, falas associadas às transformações ligadas à autonomia das mulheres ganham destaque. Já na zona rural de Pernambuco, ainda se trata de um discurso residual e mesmo extravagante.

\section{Ditos populares: o que pensam os homens}

A fim de desvelar os significados da violência de gênero entre os grupos de homens pesquisados, foi proposto, aos grupos, discutir ditos populares bastante conhecidos em todos os segmentos sociais e contextos culturais no país que expressam de maneira gritante (e, para alguns, jocosa) a dominação e violência masculina sobre as mulheres, especialmente

9 Em São Paulo, o bar e os amigos, especialmente, foram considerados como um fator de discórdia na relação, mas que poderia ser superado pela "confiança" da mulher. 
companheiras: "a gente não sabe por que está batendo, mas elas sabem por que estão apanhando"; "mulher é como bife, quanto mais apanha, mais macia fica" - e o seu oposto, expresso no dito: "em mulher não se bate nem com uma flor". Também foi lançado um dito popular que remete ao expediente de 'tomar partido'/intervir (ou não) em relações conflitivas vividas por outros casais: "em briga de marido e mulher, ninguém mete a colher".

Em relação ao primeiro ditado popular (a gente não sabe por que está batendo, mas elas sabem por que estão apanhando), observou-se uma polarização entre duas interpretações. A primeira ressaltava o exagero e o machismo inerente ao dito popular. Para metade dos participantes dos grupos focais de São Paulo, foi considerado um absurdo bater em mulher, porque ela se constitui como ser frágil. Consequentemente, tal atitude significa um ato de covardia. Mas, foi interessante perceber que a mesma lógica 'naturalizante' reveste o argumento oposto de que, por vezes, é natural ao homem, dado seu instinto agressivo e intempestivo, bater em mulher. A fala de um dos participantes paulistas ilustra tal percepção: "A violência não acontece só entre os homens, mas em todo o mundo animal. Você vê: o macaco bate na macaca. Existe o instinto do homem, dele bater".

Uma segunda interpretação aglutinou os demais participantes na defesa de que é o próprio aspecto 'natural' constitutivo do homem que o leva a bater em mulher, especialmente quando entra em cena a traição feminina. Ressalte-se que a traição (ou mesmo sua suposição) tem sido apontada como justificativa para a agressão à esposa-companheira no discurso dos homens em diferentes pesquisas (Alves \& Diniz, 2005; Couto et al., 2007). Um outro participante de São Paulo que, a princípio era contrário à violência, reconsiderou seu argumento quando a temática da traição irrompeu no debate:

Acho que não se deve bater, mas se você pega a mulher te traindo, não sei... Não se pode dizer a reação do momento... Mas um bom tapa na cara é difícil de não dar. Não deve dar um tiro, porque aí vai para a cadeia e o povo diz: 'olha lá o corno', mas um tapa... Nesse caso é mais fácil você bater na mulher do que tentar bater no cara, porque o cara, às vezes, nem sabe quem é você...

A discussão deste dito popular entre os homens da zona rural de Pernambuco remete a um melhor entendimento das diferenciações de base cultural que permeiam os contextos sociais aqui tratados (urbano/ 
rural $_{i}$ Sudeste/Nordeste). Isto porque esses homens trouxeram elementos mais explícitos do padrão de masculinidade que associa a violência contra a mulher, especialmente esposa, como punição ou correção por atos/ comportamentos contrários à sua expectativa de autoridade doméstica e de controle da sexualidade feminina (Schraiber, d'Oliveira \& Couto, 2009).

Ao contrário dos homens paulistas, que iniciaram a discussão negando o ditado e advogando a atitude da não violência, os homens da Zona da Mata pernambucana começaram justificando o ditado. Um deles legitimou o dito popular, afirmando: "É porque, se ela sabe porque tá apanhando, é porque ela sabe que errou". E outro acrescentou: "É, porque se ela num errasse, também, ela num ia apanhar".

Também merece realce o fato de que, ao contrário dos homens dos grupos de São Paulo que se esquivaram de emitir opiniões estritamente pessoais e citar participação em episódios concretos de violência contra a mulher; os homens rurais de Pernambuco não se omitiram diante do ditado e nem se incomodaram em relatar experiências pessoais, sendo que uma boa parte deles justificou o ditado tomando para si a situação:

Se eu saio para trabalhar, arrumar coisa para dentro de casa e ela sai pra transar com outro, com um macho dentro dos mato, ela errou e muito, num é isso? Então merece [apanhar].

Quando eu saio pra trabalhar que chego em casa, eu topo com o fogo apagado, eu topo com o fogo apagado, não tem comida e ela tá pra casa de um. 'Fulana, fulana', e nada! Eu espero ela chegar, quando chega pego pelo cabelo dela e é pau. Ai é pau! Tava trabalhando, não tava vadiando não. Vai pro pau. Num sei nem o que ela tava fazendo, não fez comer pra mim, vai pro pau!

E outro ainda reforça: "Eu às vezes chego a bater na minha esposa, a agredir. Eu sei por que estou batendo, ela também sabe por que tá apanhando. Agora que mulher num, num é tola! Quando eu bato, eu sei!".

O segundo ditado - "mulher é como bife, quanto mais apanha, mais macia fica" - foi explorado apenas nos grupos focais rurais de Pernambuco. Destaca-se, também neste caso, a 'naturalidade' expressa pelos participantes não apenas em justificar o dito, mas em fazer uso de experiências próprias para tal justificação. Note-se que, apesar de estarem entre desconhecidos e/ou entre pessoas de relação próxima, os homens não se abstiveram de enunciar relatos contundentes sobre a legitimidade 
e recorrência de atos de agressão, o que denota a banalização da violência física empregada contra suas mulheres.

Um dos participantes do grupo focal realizado em Tamandaré mencionou que sua mulher já tinha levado "sopapos" dele: "A minha já levou cada sopapo, que um soco meu, um tapa, não é fácil não. E depois vamos pra cama, aí vai pra cama que amansa tudo!".

Um outro arremata, comentando: "Tem mulher que gosta mesmo de levar pancada e nem tá aí. Ela (...) esquece até a dor. Aí é que vem pra cima do cara. Aí é que ela fica doida pelo cara mesmo".

Ao empregamos os termos recorrência e banalização da violência a partir das falas dos homens, especialmente os de Pernambuco, entendemos que a utilização de expressões como "esquecer a dor" e "gostar" associadas às mulheres que apanham, bem como a ideia de conjugação entre agressão física e sexo, demonstram que o entendimento desses homens quanto ao recurso da violência contra as mulheres não é apenas para punir um ato ou falha que consideram grave, mas um expediente que se integra na dinâmica de dominação-subordinação entre os parceiros, em que a compreensão de prazer sexual da mulher na visão do homem implica uma total e inequívoca subjugação do desejo e da autonomia do outro (Dantas-Berger \& Giffin, 2005).

O dito popular "em mulher não se bate nem com uma flor" foi discutido apenas pelos paulistas. Observou-se um expressivo consenso entre os participantes dos dois grupos de São Paulo. Provavelmente isto ocorreu porque a alusão à fragilidade está presente neste ditado, aspecto que se constituiu como a tônica do debate. Nesta fala, é possível observar o 'traço idílico' do argumento: "a mulher é a coisa mais linda e bela que Deus deixou pra nós; se ele inventou coisa melhor, guardou pra ele".

Mas, ainda quanto a esta última expressão, observamos outras interessantes considerações que relativizam o sentido do ditado. Entre elas, a de que há mulheres que gostam de apanhar, assim como há homens que gostam de bater em mulher; e, também, o argumento da "causa e efeito", expresso na fala de um dos participantes, e que se aproxima da justificação do recurso à violência como amplamente expresso pelos homens rurais de Pernambuco: "Não sei [se concorda], porque eu acredito na ótica da causa e do efeito: se trair eu não tenho como me segurar".

$\mathrm{O}$ último ditado explorado pelos grupos a pedido dos moderadores - "em briga de marido e mulher, ninguém mete a colher" - trouxe grandes semelhanças nos discursos dos homens em São Paulo e Pernambuco. 
Inicialmente, grande parte concordou com ele, apresentando motivos diferentes, com algumas poucas exceções. $\mathrm{O}$ argumento central dos participantes paulistas foi o de que um desconhecido, e mesmo um amigo, não deveria se meter em briga de casal já que, com uma possível reconciliação, ele seria o maior prejudicado. Em Pernambuco, a regra da não 'intromissão' neste tipo de conflito parece ainda mais forte. Um dos pernambucanos comentou: "Se eu puder passar correndo, mode não chegar perto [de briga entre casal], eu passo".

Mas, em casos mais graves, uma possível intervenção indireta colocada pelos homens de São Paulo foi avisar à polícia. No entanto, os participantes apontam alguns casos em que a intromissão direta - pessoal - pode ocorrer: situações onde o risco de vida é iminente - quando, por exemplo, alguém porta uma arma; quando a briga ocorre no espaço público; e quando a mulher envolvida possui um grau de parentesco próximo (mãe e irmã):

Só tem uma situação diferente: quando é dentro de sua família. Se eu ver meu cunhado batendo na minha irmã, aí é diferente... Aí eu me meto. Meu pai já virou a mesa com tudo em cima da minha mãe. Terrível... Ele era o errado... Parece que ele xingou ela e ela só chamou ele de corno, frouxo, palavrinha simples e ele não aguentou: virou a mesa com tudo... No horário da janta... Aí eu e meu irmão 'voamo' em cima dele: 'porra, o pai quer matar a mãe'... Se cai aquela mesa com tudo em cima dela, nas pernas dela, tinha quebrado as pernas...

Entre os pernambucanos, embora a 'intromissão' em brigas de casais também tenham merecido algumas justificativas quando envolviam pessoas da família (mãe/irmã), a relativização a partir da referência à família e ao parentesco foi bem maior do que em São Paulo. Enquanto um dos homens defendeu: "Se for irmã minha, aí é diferente, né? É meu sangue, por ela ou tudo ou nada". Outro lançou argumento contrário:

[Se for uma irmã] Eu não vou não, porque ela tem que valorizar ela mesmo. Porque, se ela tá apanhando ela sabe por que é. Se ela tá apanhando do marido dela, ela tem obrigação de ir embora, ela fica porque quer. Mas, se ela for pra minha casa e ele for lá bater nela, aí o negócio complica. Se ele vai bater nela na minha casa, ele vai ter que bater neu também. 
Destes extratos de falas dos homens em ambos estados, podemos levantar alguns argumentos sobre o simbolismo que perpassa a construção das masculinidades entre os homens pesquisados nas áreas rurais de Tamandaré e Carpina e em São Paulo.

No caso dos pernambucanos da Zona da Mata, as regras de convivência e reciprocidade entre os casais se mostram mais fortes e fixadas em 'papéis' e, com isto, inibem a 'intromissão' de terceiros, mesmo quando se trata de consanguíneos. A quebra de tal regra só se justifica quando além da consanguinidade entra em cena o aspecto da residência.

A casa, símbolo e locus da família, ocupa espaço elevado nas relações conjugais (Scott, 1990). Na casa, o respeito do agregado à família afim restringe sua ascendência e dominação (especialmente quando do recurso à violência) contra a mulher. Além do mais, em se tratando de conflitos de casal há a ideia, presente tanto entre os pernambucanos como entre os paulistas, de que o espaço onde estes devem se desenrolar é sua própria 'casa' e não a de outros. Assim, para os homens paulistas, uma das possibilidades de intervenção em casos de briga/violência entre casais é quando esta se dá no domínio público, âmbito, por excelência, de todos, onde a ordem e a lei (Da Matta, 1986) devem estar presentes.

\section{Violência de gênero, masculinidades e diversidade cultural: questões para o campo da saúde}

Com base na literatura socioantropológica sobre a constituição das masculinidades, especialmente nos setores populares urbanos (Scott, 1990; Nascimento, 1999), mas também em áreas rurais (Almeida, 1996), vemos que o homem é, por 'natureza', considerado como sexualmente insaciável e, portanto, pode, porque sente necessidade, ter relações extraconjugais.

Uma outra característica genérica do 'ser homem' se refere à associação com o 'ser provedor', moral e material, da família (Sarti, 1996). Quanto à referência à moral, esta é tida como valor que remete, sobremaneira, à honra. Como bem definiu Pitt-Rivers (1971), quando associada à pobreza, a honra constitui-se como virtude moral, não estando associada simplesmente à posição social.

Sendo a honra um dos principais pilares sobre o qual os homens constroem e vivenciam as relações com os 'outros' (mulheres, homens mais pobres, homens mais ricos, crianças/adolescentes), não é de se 
estranhar que, na relação homem-mulher, a honra se constitua como elemento que está sempre à prova. Portanto, o medo da infidelidade feminina, relacionado à vinculação entre masculinidade e virilidade, tornase presente.

Por fim, um outro aspecto que vale referendar quanto ao modelo de masculinidade em ambos os grupos investigados é o controle sobre a própria vontade (Nascimento, 1999). O homem não deve jamais se submeter à vontade do 'outro', especialmente quando este é tido como inferior na hierarquia social (mulheres e crianças, de forma geral, e 'outros' homens que detêm menos prestígio: bêbados, miseráveis, vagabundos, homossexuais).

Também com base na literatura, vê-se que, nos poucos estudos que incluem a face masculina dos episódios de violência contra mulher, sobressai o reforço de interpretações sobre um ethos masculino que associa violência e masculinidade (Nolasco, 2001; Welzer-Lang, 2001), embora a atribuição de 'educador', assumida pelo homem em relação à mulher, também seja considerada em alguns estudos (Schraiber, d'Oliveira \& Couto, 2009).

Destaquem-se, ainda, a ênfase sobre a constituição da identidade masculina no processo de socialização, no qual o machismo prevalece, e a configuração de um princípio simbólico de honra que rege as expectativas e as atuações dos homens na 'casa' e na 'rua', via crenças internalizadas de autoridade e conexão entre virilidade e violência (Fuller, 2001). Nesta última linha interpretativa, o uso da violência (de caráter psicológico, físico ou sexual) não seria elemento constitutivo da relação afetiva/ conjugal. Antes, sua emergência responderia à necessidade masculina de (re)colocar elementos associados a honra, autoridade e poder na relação quando esta é questionada ou está em crise.

No argumento de Connell (2001), para um homem, a violência é uma possibilidade de resposta à demanda de desempenho de seu papel social. Embora seja estimulada de diferentes formas durante o processo de socialização, torna-se um elemento-chave na reafirmação de um determinado tipo de subjetividade masculina quando o sujeito não encontra para si formas de reconhecimento e inserção social.

Poder, hierarquia e reciprocidade permeiam o cotidiano das relações afetivas entre homens e mulheres, dando forma e dinâmica à vida conjugal e familiar. É, pois, a investigação do caráter fluido e dinâmico destas relações, que respondem às transformações no universo familiar e no lugar da mulher na sociedade, que consubstanciará uma compreensão ampliada 
e relacional da violência psicológica, física e/ou sexual no âmbito das relações de afetividade/conjugalidade entre moradores das camadas populares da cidade de São Paulo e da área rural de municípios da Zona da Mata pernambucana.

Não obstante a validade deste argumento, é preciso lembrar que a 'diluição' do padrão mais tradicional pelos homens paulistas não significa que ele deixou de existir. Mas, quando se trata de um tema como a violência, é possível reconhecer que tal direção possa provocar posteriores repercussões. Inicialmente, estas podem aparecer em termos de um discurso 'politicamente correto' que valoriza a emancipação, autonomia e poder da mulher, mas que pode, paulatinamente, ultrapassar tal superficialidade e se inserir como novos valores e práticas em defesa da não violência em geral e da violência de gênero em particular.

Acredita-se que isto é possível, dado, como observado nos grupos em São Paulo, um certo 'policiamento' e 'constrangimento' dos sujeitos particulares devido à pressão social (mídia, familiares, pessoas do trabalho, amigos, entre outros).

Trata-se, pois, de entender as profundas influências das conjunções dos diversos referenciais identitários sobre as representações e práticas dos sujeitos, que configuram particularidades culturais. Embora a violência de gênero se mostre disseminada entre diferentes culturas e no interior dos grupos e segmentos sociais, perder de vista o caráter da diversidade sociocultural apenas rotula tal fenômeno como 'universal' e, com isto, perde-se a possibilidade de compreensões e intervenções mais fecundas e consequentes no plano da prevenção e promoção da saúde.

Em outros termos, são as nuances apontadas das representações e concepções masculinas no que diz respeito aos gêneros e suas atribuições sociais e, em especial, à violência de gênero que permitem a reflexão acerca dos impactos desses achados no campo da saúde, em particular para ações de prevenção e promoção à saúde.

A problemática da violência no contexto das relações conjugais é, antes de tudo, uma questão social. Neste sentido, em um primeiro momento poderia não ser reconhecida como objeto próprio da saúde. Mas, como bem apontam Minayo (1994), Krug e colaboradores (2002) e Schraiber, d'Oliveira e Couto (2006), as violências e, dentre estas, a violência contra a mulher constituem tema pertinente ao campo da saúde pelo impacto que provocam na qualidade de vida dos sujeitos envolvidos, em termos de lesões físicas, psíquicas e pelos danos morais; pelas exigências 
de atenção e cuidados dos serviços de saúde; e, sem dúvida, pela concepção ampliada de saúde, a de saúde integral, segundo a qual a violência passa a ser considerada como objeto da intersetorialidade, a que o campo médico-social se conecta.

Tomando-se a integralidade em saúde, constata-se que as estratégias de promoção da saúde são vias positivas de enfocar os modos de viver do humano no tocante ao processo de saúde-adoecimento e cuidado. Considerando-se que as ações preventivas são intervenções orientadas para evitar o surgimento de doenças e reduzir sua incidência e prevalência nas populações, a promoção da saúde teria um significado bem mais amplo do que a prevenção, pois, como aponta Czeresnia (2003), não se restringe a uma determinada doença ou desordem, mas serve para ampliar a saúde e o bem-estar geral.

Somado a isto, a promoção, em uma perspectiva progressista, considera que os modos de viver não se referem apenas ao exercício individual pautado na liberdade e autonomia, pois, antes, pertencem à esfera da coletividade na qual os aspectos simbólicos da cultura e estruturais da sociedade dão forma ao vivido.

Nesta direção, poder-se-ia argumentar que políticas de saúde voltadas à prevenção e, sobretudo, à promoção da saúde deveriam lançar mão de estratégias transversais que conferissem visibilidade às diferenças, expressas em necessidades de grupos populacionais (homens e mulheres), territórios e ambientes (Sudeste/Nordeste) e formações culturais (urbano/ rural), visando a adotar estratégias para minimizar situações de vulnerabilidade que defendam a equidade no acesso e estejam orientadas para integralidade da atenção e do cuidado. ${ }^{10}$

Destaca-se, ainda, que a investigação das particularidades socioculturais da problemática da violência contra a mulher, a partir do referencial de gênero e na ótica dos homens, representa inovações no campo da saúde, tendo em vista o imperativo do deslocamento do olhar em duas direções.

Uma primeira remete à incorporação, nas atividades de educação em saúde, de novos aspectos (como as noções de honra, liberdadeautonomia, traição, sexualidade com interação afetiva e entre sujeitos mais simétricos, entre outros) que traduzem a violência do plano do vivido

10 Embora esses princípios estejam presentes na Política Nacional de Promoção à Saúde (Brasil, 2007), o percurso para sua efetiva realização é muito longo. 
pelos sujeitos para o campo da intervenção em saúde, o que pode proporcionar intervenções que respeitem o caráter relacional implicado no problema violência contra a mulher.

Como apontaram Schraiber, Gomes e Couto (2005), tomando-se em particular as questões da prevenção e promoção, pode-se perceber que a inclusão dos homens no debate sobre saúde não se restringe à saúde masculina, mas consegue ganhos para a saúde feminina em temas que só avançam na medida em que se consegue a participação masculina em seu enfrentamento.

A segunda inovação aponta para, a partir do acúmulo de conhecimento acerca da diversidade de vivência das masculinidades, a possibilidade de ampliação de atividades com os homens no campo da promoção à saúde e à cultura de paz, de forma que tais atividades possam ganhar em efetividade.

\section{Referências}

ALMEIDA, M. V. Gênero, masculinidade e poder: revendo um caso do sul de Portugal. Anuário Antropológico, 95: 161-189, 1996.

ALVES, S. L. \& DINIZ, N. M. 'Eu digo não, ela diz sim': a violência conjugal no discurso masculino. Revista Brasileira de Enfermagem, 58(4): 387-392, 2005.

CONNELL, R. Men and Violence. Santo Domingo: UN-INSTRAW, 2001. Disponível em: <http://www.uninstraw.org/mensroles>. Acesso em: 26 jul. 2007.

COUTO, M. T. \& SCHRAIBER, L. B. Homens, saúde e violência: novas questões de gênero no campo da Saúde Coletiva. In: MINAYO, M. C. S. \& COIMBRA JR., C. E. A. (Orgs.). Críticas e Atuantes: ciências sociais e humanas em saúde na América Latina. Rio de Janeiro: Editora Fiocruz, 2005.

COUTO, M. T. et al. Concepções de gênero entre homens e mulheres de baixa renda e escolaridade acerca da violência contra a mulher, São Paulo, Brasil. Ciência \& Saúde Coletiva, 11(supl.): 1.323-1.332, 2007.

CZERESNIA, D. O conceito de saúde e a diferença entre prevenção e promoção. In: CZERESNIA D. \& FREITAS C. M. (Orgs.). Promoção da Saúde: conceitos, reflexões, tendências. Rio de Janeiro: Editora Fiocruz, 2003.

DA MATTA, R. A Casa e a Rua: espaço, cidadania, mulher e morte no Brasil. São Paulo: Brasiliense, 1986.

DA MATTA, R. Tem pente aí? Reflexões sobre a identidade masculina. In: CALDAS, D. (Org.). Homens: comportamento, sexualidade e mudança. São Paulo: Senac, 1997. 
DANTAS-BERGER, S. M. \& GIFFIN, K. A violência nas relações de conjugalidade: invisibilidade e banalização da violência sexual? Cadernos de Saúde Pública, 21(2): 417-425, 2005.

FULLER, N. She made me go out of my mind: marital violence from the male point of view. Development, 44(3): 25-29, 2001.

GOMES, N. P. \& FREIRE, N. M. Vivência de violência familiar: homens que violentam suas companheiras. Revista Brasileira de Enfermagem, 58(4): 176-179, 2005.

GOMES, R. Sexualidade Masculina, Gênero e Saúde. Rio de Janeiro: Editora Fiocruz, 2008

GREGORI, M. F. Relações de violência e erotismo. Cadermos Pagu, (20): 87-120, 2003

GREIG, A. Political Connections: men, gender and violence. United Nations International Research and Training Institute for the Advancement of Women, 2001. Disponível em: <www.um-instraw.org./mensroles>. (Working Paper Series on Men's Roles and Responsabilities in Ending Gender Based Violence).

HEISE, L ${ }_{i}$ ELLSBERG, M. \& GOTTEMOELLER, M. Ending Violence against Women. Baltimore: Johns Hopkins University School of Public Health, 1999. (Population reports, Series L, 11).

KAPLAN, D. \& MANNERS, R. Teoria da Cultura. Rio de Janeiro: Zahar, 1981.

KRUG, E. G. et al. (Eds.). World Report on Violence and Health. Genève: World Health Organization, 2002.

MINAYO, M. C. S. A violência social sob a perspectiva da saúde pública. Cadernos de Saúde Pública, 10(7): 7-18, 1994.

NASCIMENTO, P. F. 'Ser Homem ou ser Nada': diversidade de experiências e estratégias de atualização do modelo hegemônico da masculinidade em Camaragibe/PE, 1999. Dissertação de Mestrado em Antropologia, Recife: Universidade Federal de Pernambuco.

NOLASCO, S. De Tarzan a Homer Simpson: banalização e violência masculina em sociedades contemporâneas ocidentais. Rio de Janeiro: Rocco, 2001.

PITT-RIVERS, J. Honra e posição social. In: PERISTIANY, J. G. (Org.). Honra e Vergonha: valores das sociedades mediterrâneas. Lisboa: Fundação Calouste Gulbenkian, 1971.

PORTELLA, A. P. et al. Homens: sexualidades, direitos e construção da pessoa. Recife: SOS Corpo, Instituto Papai, 2004.

ROSA, A. G. et al. A violência conjugal contra a mulher a partir da ótica do homem autor da violência. Saúde e Sociedade, 17(3): 152-160, 2008. 
SAFFIOTI, H. \& ALMEIDA, S. A. Violência de Gênero. Rio de Janeiro: Revinter, 1995.

SARTI, C. A Família como Espelho: um estudo sobre a moral dos pobres. Campinas: Autores Associados, 1996.

SCHRAIBER, L. B.; D'OLIVEIRA, A. F. P. L. \& COUTO, M. T. Violência e saúde: estudos científicos recentes. Revista de Saúde Pública, 40 (n. esp.): 112-120, ago. 2006 .

SCHRAIBER, L. B.; D'OLIVEIRA, A. F. P. L. \& COUTO, M. T. Violência e Saúde: contribuições teóricas, metodológicas e éticas de estudos da violência contra a mulher. Cadernos de Saúde Pública, 25 (supl. 2): S205-S216, 2009.

SCHRAIBER, L. B.; GOMES, R. \& COUTO, M. T. Homens e saúde na pauta da saúde coletiva. Ciência \& Saúde Coletiva, 10(1): 7-17, 2005.

SCHRAIBER, L. B. et al. WHO multi-country study on women's health and domestic violence against women. Relatório de Pesquisa. São Paulo, 2002.

SCOTT, R. P. O homem na matrifocalidade: gênero, percepção e experiências do domínio doméstico. Cadernos de Pesquisa, 73: 38-47, 1990.

WELZER-LANG, D. A construção do masculino: dominação das mulheres e homofobia. Estudos Feministas, 2: 460-482, 2001. 



\title{
Masculinidades, Violência e Homofobia
}

\author{
Sérgio Carrara e Gustavo Saggese
}

Ao longo das últimas décadas, situações de violência e discriminação vêm sendo abordadas com maior frequência no âmbito da saúde pública e coletiva no Brasil. Seja do ponto de vista dos encargos que representa para os serviços de saúde, seja do ponto de vista das conexões entre vulnerabilidade social, discriminação e processos de adoecimento, a violência tornou-se importante objeto de reflexão na área da saúde (Minayo, 1994, 2006).

As discussões sobre o fenômeno da violência interpessoal têm, por sua vez, colocado a masculinidade e os homens no centro do debate. ${ }^{1}$ Isso se deve, ao menos em parte, ao verdadeiro abismo estatístico que existe entre homens e mulheres quando se comparam taxas de mortalidade por causas externas, muito maiores entre os primeiros. Entre tais causas, está o homicídio, perpetrado, sobretudo, por homens (Souza, 2005). É muito clara, portanto, a implicação da masculinidade em contextos onde a violência toma forma, sejam os homens vítimas ou algozes, seja a violência exercida contra mulheres ou contra outros homens.

Como diferentes trabalhos têm apontado, masculinidade e violência se articulam de múltiplas formas, especialmente quando se discutem temas específicos, como é o caso da 'violência contra mulheres'. ${ }^{2}$ Nesse campo, foi elaborado o conceito de 'violência de gênero', atualmente na pauta

\footnotetext{
Em artigo sobre crime e violência no Brasil, Zaluar (1999) destaca a reiteração de um ethos masculino diante da possibilidade de uma emasculação simbólica como uma das motivações que leva homens jovens envolvidos no tráfico de drogas a confrontar seus pares.

2 Ver, entre outros, Brandão (2006), Correa (2002) e Gregori (1993).
} 
das mais diversas áreas do conhecimento e de políticas públicas. No entanto, mesmo que o conceito de 'violência de gênero' tenha sido desenvolvido a partir da análise do exercício abusivo de poder de homens sobre mulheres, ele também parece ser crucial para a compreensão da violência intragênero, isto é, da violência que ocorre entre homens. ${ }^{3}$

Homens que rompem com convenções sociais de gênero e sexualidade estão particularmente expostos a situações de violência e discriminação. Ainda que de divulgação relativamente recente, conceitos como 'violência contra homossexuais', 'violência homofóbica' e 'homofobia' vêm sendo utilizados por ativistas e pesquisadores na tentativa de compreender a especificidade desse fenômeno, alvo de crescente preocupação não só por parte da militância do movimento de Lésbicas, Gays, Bissexuais, Travestis e Transexuais (LGBT), ${ }_{1}^{4}$ mas também do governo e da mídia. Porém, as relações conceituais entre a chamada 'violência de gênero' e a 'violência homofóbica' permanecem ainda pouco exploradas. No caso desta última, rupturas com as convenções sociais relativas à sexualidade (manutenção de práticas e desejos não heterossexuais) e as convenções de gênero (manifestação pública de atributos e comportamentos considerados femininos por homens e masculinos por mulheres) parecem diferencialmente implicadas nos contextos de violência e discriminação.

Com o significado mais imediato de ódio ou repulsa a homossexuais, a expressão 'homofobia' tem recebido inúmeras críticas no plano acadêmico, entre elas a de não permitir que, nos casos concretos, se diferencie o que é devido ao preconceito contra certas práticas e desejos sexuais do que é devido ao preconceito contra a adoção de uma performance de gênero não convencional. ${ }^{5}$ Essa crítica se constrói a partir

3 Essa conexão é particularmente perceptível no caso da violência sexual. Para isso, ver Lopes (2005) e Sarti e colaboradores (2006).

4 A sigla foi alterada durante a I Conferência Nacional GLBT - Gays, Lésbicas, Bissexuais, Travestis e Transexuais - brasileira, ocorrida entre os dias 5 e 8 de junho de 2008 em Brasília, decidindo-se por inverter o 'L' pelo ' $\mathrm{G}$ '. Atualmente, portanto, o movimento é chamado de LGBT e, para efeitos do presente trabalho, adotaremos a nova sigla.

5 A palavra homofobia foi cunhada no final da década de 1960 pelo psicólogo americano George Weinberg, que via uma natureza patológica no comportamento aversivo em relação a homossexuais. No entanto, o termo tem sido utilizado como modelo para nomear diversas atitudes negativas envolvendo gênero e sexualidade e, apesar de suas limitações, teve reconhecida importância na compreensão das experiências de rejeição, hostilidade e invisibilidade dos homossexuais, deslocando o 'problema' da homossexualidade para os 'normais' que não toleram gays e lésbicas (Herek, 2004). 
da ideia de que, embora articulados, sexualidade e gênero devem ser considerados como planos distintos de hierarquização de diferenças sociais.

No plano político, a expressão 'homofobia' tem sido criticada porque diferentes sujeitos reivindicam a especificidade da violência que os atinge, cunhando expressões como 'transfobia' ou 'lesbofobia'. Do seu ponto de vista, 'homofobia' se aplicaria apenas para homens homossexuais ou gays. ${ }^{6}$ Ao longo deste trabalho, tomaremos, portanto, a expressão 'violência homofóbica' como um conceito em construção, cujo refinamento depende de pesquisas empíricas mais abrangentes e detalhadas.

Nas últimas décadas, começaram a surgir no Brasil pesquisas que, com base em fontes jornalísticas, procuraram analisar a violência homofóbica no país, principalmente no que diz respeito aos assassinatos. ${ }^{7} \mathrm{~A}$ partir de 2003, uma série de surveys realizados nas Paradas do Orgulho LGBT brasileiras foi coordenada pelo Centro Latino-Americano em Sexualidade e Direitos Humanos, do Instituto de Medicina Social, da Universidade do Estado do Rio de Janeiro (Clam/IMS/Uerj) e pelo Centro de Estudos de Segurança e Cidadania da Universidade Cândido Mendes (CESeC/ Ucam) envolvendo múltiplos parceiros. ${ }^{8}$ Dando continuidade à investigação dos padrões de vitimização dessa população, tais surveys passaram a abordar também questões relacionadas a sociabilidade, afetividade, sexualidade, política e direitos (Ramos \& Carrara, 2006).

Este capítulo tem por objetivo aprofundar a discussão, explorando tanto os dados quantitativos obtidos nos surveys, quanto dados qualitativos

6 Especialmente no plano político, o termo gay tem sido de modo geral utilizado como sinônimo de homem homossexual, mesmo que, no plano social, mulheres lésbicas e também travestis o utilizem eventualmente para expressarem sua identidade.

7 Pioneiro na empreitada, o Grupo Gay da Bahia (GGB) dispõe de um registro documentado de assassinatos em que a homossexualidade da vítima é considerada o principal motivador, mesmo que de forma indireta (Ramos \& Carrara, 2006). Para mais informações, ver Mott (2000) e Mott e Cerqueira (2001).

8 A pesquisa envolveu em suas diferentes edições as seguintes organizações não governamentais (ONGs): Grupo Arco-Íris de Conscientização Homossexual, Nuances: Grupo pela Livre Expressão Sexual, Associação da Parada do Orgulho GLBT de São Paulo, Instituto Papai e Fórum LGBT de Pernambuco. No âmbito universitário, além do CESeC/Ucam, participaram do trabalho: Departamento de Antropologia da Universidade de São Paulo (USP), Núcleo de Estudos de Gênero Pagu/Universidade Estadual de Campinas (Unicamp), Núcleo de Pesquisa em Antropologia do Corpo e da Saúde (Nupacs) da Universidade do Rio Grande do Sul (UFRGS) e Universidade Federal de Pernambuco. Para o resultado de cada um dos surveys, ver Carrara e Ramos (2005), Carrara e colaboradores (2006, 2007). 
produzidos a partir de entrevistas em profundidade realizadas com homens homossexuais, na cidade do Rio de Janeiro, entre os meses de abril e outubro de 2008. Por meio delas procurou-se compreender as maneiras pelas quais estes indivíduos 'se descobrem' atraídos por pessoas do mesmo sexo e buscam meios de lidar com esse desejo, abordando as estratégias de manipulação e ocultamento da orientação sexual que frequentemente se mostram necessárias perante o preconceito e a discriminação que podem ocorrer em diversos círculos de sociabilidade, como a família, o ambiente de trabalho e os amigos. ${ }^{9}$ No entanto, antes de seguirmos com a nossa análise, é importante explicitar algumas inquietações metodológicas.

\section{"Homens"?}

Entre 2003 e 2006, foram aplicados 3.229 questionários contendo questões fechadas e abertas em quatro capitais brasileiras: Rio de Janeiro, Porto Alegre, São Paulo e Recife. ${ }^{10}$ Procurava-se conhecer o perfil social dos(as) participantes das Paradas de Orgulho LGBT, sem descartar, no que concerne a informações sociológicas mais gerais, os/as heterossexuais presentes no evento. ${ }^{11}$ Buscava-se também conhecer os padrões de vitimização apresentados pela população LGBT.

Perguntas referentes à discriminação e à violência, bem como à participação política, sociabilidade e cuidados com a saúde, foram feitas somente aos que mantinham algum tipo de autoidentificação não heterossexual. Tal identificação foi obtida com a pergunta "Com qual dessas categorias você mais se identifica?", oferecendo-se como alternativas: gay, lésbica, homossexual, travesti, transexual, bissexual e entendido/a.

No primeiro survey, realizado na Parada de 2003, no Rio de Janeiro, o 'sexo' do(a) respondente não foi perguntado, pois se acreditava que categorias como 'gay', 'homossexual' e 'lésbica' iriam se referir imediatamente

9 Os resultados de trabalho qualitativo foram mais amplamente explorados em Saggese (2009).

10 A pesquisa também foi realizada em Belém, mas os dados ainda estão em análise e não serão trabalhados aqui.

11 Nas paradas aqui consideradas, eles e elas compunham quase $23 \%$ do total de respondentes. É interessante notar que, entre heterossexuais presentes, temos, sobretudo, mulheres, o que parece revelar que homens heterossexuais talvez considerem sua presença em eventos desse tipo como virtual ameaça à sua masculinidade. 
a homens, no caso das duas primeiras, ou a mulheres, no caso da última. Os dados revelaram, entretanto, que um número significativo de mulheres preferia identificar-se, por exemplo, como gay ou homossexual. A possibilidade de múltiplas identificações atravessando as fronteiras de gênero fez, de um lado, com que as diferentes categorias identitárias autoatribuídas previstas no questionário fossem trabalhadas a fim de compor categorias analíticas mais abrangentes, chamadas por nós 'identidades sexuais agregadas'. ${ }^{12}$ Além disso, esse problema inicial impôs uma reflexão mais detida sobre o que significa, em determinados contextos sociais, perguntar qual o sexo de uma pessoa. No caso daqueles que transitaram ou estão transitando por categorias de sexo/gênero, como travestis e transexuais, por exemplo, essa pergunta pode ter várias respostas, dependendo do ponto de suas trajetórias sociais a que o pesquisador se refere, do modo como se percebem, ou mesmo de como são socialmente percebidas.

Ao longo dos surveys seguintes, tornou-se claro que 'sexo', geralmente uma das menos polêmicas 'variáveis' em pesquisas quantitativas, deveria ser considerada como uma das mais complexas naquele contexto. Nos dois surveys subsequentes, Rio de Janeiro e Porto Alegre, ficou a cargo dos entrevistadores anotar o sexo do/a respondente. Contudo, além dos problemas éticos que implicava atribuir um sexo aos sujeitos da pesquisa independentemente de sua opinião, muitos entrevistadores simplesmente se esqueciam de fazer o registro dessa variável.

A partir do quarto survey, realizado na Parada de São Paulo, em 2005, decidiu-se que a pergunta seria formulada de uma maneira diferente para que se pudessem separar homens e mulheres na análise: "Com que sexo você foi registrado ao nascer?". Por razões óbvias, uma pergunta como essa, formulada a alguém que considere sua masculinidade ou feminilidade como autoevidentes, continuou a causar embaraços, mas foi a maneira encontrada para dar conta do problema.

Se, do ponto de vista metodológico, tal saída se mostrou relativamente eficaz no caso dos surveys, do ponto de vista do objeto que nos propomos a trabalhar aqui, o problema permanece. E não se trata de questão meramente abstrata ou teórica, pois, dependendo da definição que damos a 'homem', seremos remetidos a sujeitos distintos e a um conjunto

12 Dessa forma, a partir das oito alternativas oferecidas aos/às respondentes, foram elaboradas cinco categorias analíticas que agrupavam as anteriores: 'homem homossexual', 'mulher homossexual', 'homem trans', 'mulher trans', 'homem bissexual' e 'mulher bissexual'. Para diferenciá-las, optamos por usá-las aqui sempre entre aspas simples. 
diferente de dados empíricos. Com as informações de que dispomos, discutir a chamada violência homofóbica a partir da 'experiência masculina' nos conduz a uma questão aparentemente banal, mas sumamente importante: que sujeitos estariam incluídos em nossa análise? Entre as pessoas 'trans' (travestis e transexuais), seria pertinente considerar apenas 'homens trans', isto é, pessoas que viveram parte de suas vidas como mulheres, ainda que tenham passado por um longo processo de transformação corporal para assumir uma identidade social e legal masculina? Travestis deveriam ou não fazer parte do recorte? Certamente esse problema pode ter diferentes soluções, mas o importante aqui é apontar para o fato de que trabalhar com questões relativas à masculinidade do ponto de vista da chamada população LGBT coloca de início um desafio perturbador: afinal, de que 'homens' falamos? O que define certos sujeitos como homens: seu perfil genético, sua anatomia, seu equilíbrio hormonal, a percepção subjetiva de seu gênero ou o modo como outros os percebem?

Acreditamos que tal inquietação, especialmente cara ao contexto de pesquisas socioantropológicas, deva ser considerada crucial também para quem se dedica a pensar ou promover a 'saúde do homem'. Não se trata aqui de aprofundar a discussão sobre gênero ou sobre políticas identitárias baseadas em categorias de gênero, mas de esclarecer que, para abordar a violência homofóbica a partir dos resultados dos surveys, optamos por discutir os dados relativos a todos os sujeitos que declararam terem sido classificados como 'homens ao nascer'. Isso significa que a análise está centrada naqueles que foram classificados no âmbito da pesquisa como 'homens homossexuais' e 'homens bissexuais', ${ }^{13}$ mas também como 'mulheres trans', categoria que agrega tanto as que se autoidentificaram como travestis ou transexuais, quanto as que, identificando-se de outro modo, faziam naquele momento uso de hormônio ou silicone para a construção de um corpo feminino. ${ }^{14}$

Estamos conscientes de que, no plano político, 'mulheres trans' lutam atualmente para serem consideradas social e legalmente como mulheres tout court. Porém, para além do fato de terem sido classificadas como homens ao nascer, sua inclusão em um texto centrado na discussão sobre masculinidade justifica-se duplamente. Em primeiro lugar, pensamos que a experiência da travestilidade e da transexualidade é dinâmica,

13 Os que se disseram 'gays', 'homossexuais', 'entendidos' ou 'bissexuais'.

14 Do conjunto de 2.479 respondentes não heterossexuais, apenas 186 foram consideradas 'mulheres trans'. O número de 'homens trans' na amostra, apenas 6 ou $0,2 \%$ do total, os torna estatisticamente pouco significativos. 
passando por graus variados de elaboração da feminilidade em corpos inicialmente percebidos como masculinos. Também, quando comparados aos dados de 'homens homossexuais' e 'homens bissexuais', os dados referentes às 'mulheres trans' permitem perceber mais claramente a articulação entre gênero e sexualidade na configuração das experiências de preconceito, discriminação e violência homofóbicas.

\section{Masculinidade(s) e homofobia}

No conjunto de surveys realizados durante as Paradas do Orgulho LGBT brasileiras, chama a atenção o número expressivo de homens (ou seja, de indivíduos classificados como homens ao nascer) presentes aos eventos (60\%). ${ }^{15}$ Quando comparado à população brasileira, o conjunto de entrevistados nas quatro cidades mostra-se significativamente mais jovem, ${ }^{16}$ e, além disso, apresenta taxas de escolaridade bem mais elevadas. ${ }^{17}$ Entre os homens não heterossexuais, quase $40 \%$ foram classificados como 'homens homossexuais' e apenas 5,3\% como 'homens bissexuais', ${ }^{18}$ sendo que esses últimos encontravam-se, sobretudo, entre os mais jovens. As distribuições relativas às identidades autoatribuídas e agregadas podem ser vistas nos Gráficos 1 e 2 (a seguir).

Para avaliar experiências de discriminação, no questionário se propunham situações bem concretas, relativas a diferentes círculos de sociabilidade. Perguntava-se, por exemplo, se "devido à sexualidade", o(a) respondente já havia passado por situações como: "não ter sido selecionado(a) no emprego"; "ter recebido tratamento diferenciado ou ter sido impedido(a) de entrar em comércio/locais de lazer", "ter sido mal

15 Esse número é superior ao número de homens presentes na sociedade brasileira como um todo que, segundo Pesquisa Nacional por Amostra de Domicílios (Pnad 2006/2007), era de $48,8 \%$.

16 Se compararmos as faixas de 22-29 anos e de 30-39, por exemplo, temos em nossa amostra $33,3 \%$ de participantes na primeira e $22,4 \%$ na segunda. Em relação ao conjunto da população brasileira, o censo de 2000 apontava, para as mesmas faixas, apenas $13,7 \%$ e $15 \%$, respectivamente. As proporções se invertem na faixa dos que dizem ter mais de 40 anos. Em nossa amostra, eles representam $17 \%$; para a população brasileira, seriam 24,3\%.

17 Em nossa amostra, 71,6\% declararam ter pelo menos 11 anos de estudo, ao passo que apenas $28,9 \%$ da população brasileira apresentava o mesmo grau de escolaridade, de acordo com os dados da Pnad 2006/2007.

18 Entre as mulheres, também há uma diferença notável, mas comparativamente menor (18,5\% de 'mulheres homossexuais' e 5,4\% de 'mulheres bissexuais'). 
atendido(a) em serviços de saúde ou por profissionais de saúde". Considerando a totalidade da amostra, 57\% de todos(a)s respondentes declararam ter sofrido pelo menos uma das formas de discriminação apresentadas no questionário. Em todas as situações, 'homens homossexuais' apresentaram porcentagens relativamente mais altas do que 'homens bissexuais', atrás apenas das 'mulheres trans'.

É interessante notar que os números de experiências de discriminação são mais próximos quando se perguntou sobre círculos de sociabilidade mais íntimos, indo de aproximadamente 33\%, entre 'homens homossexuais' e 'mulheres trans', a $26 \%$ entre 'homens bissexuais'. Assim, no ambiente familiar, 'homens homossexuais' e 'mulheres trans' apresentam taxas idênticas no que se refere a experiências de discriminação $(26,7 \%)$, seguidos por 'homens bissexuais', que apresentam taxas um pouco inferiores $(20,7 \%)$.

Gráfico 1 - Identidades sexuais autoatribuídas

$\mathrm{N}=3.229$

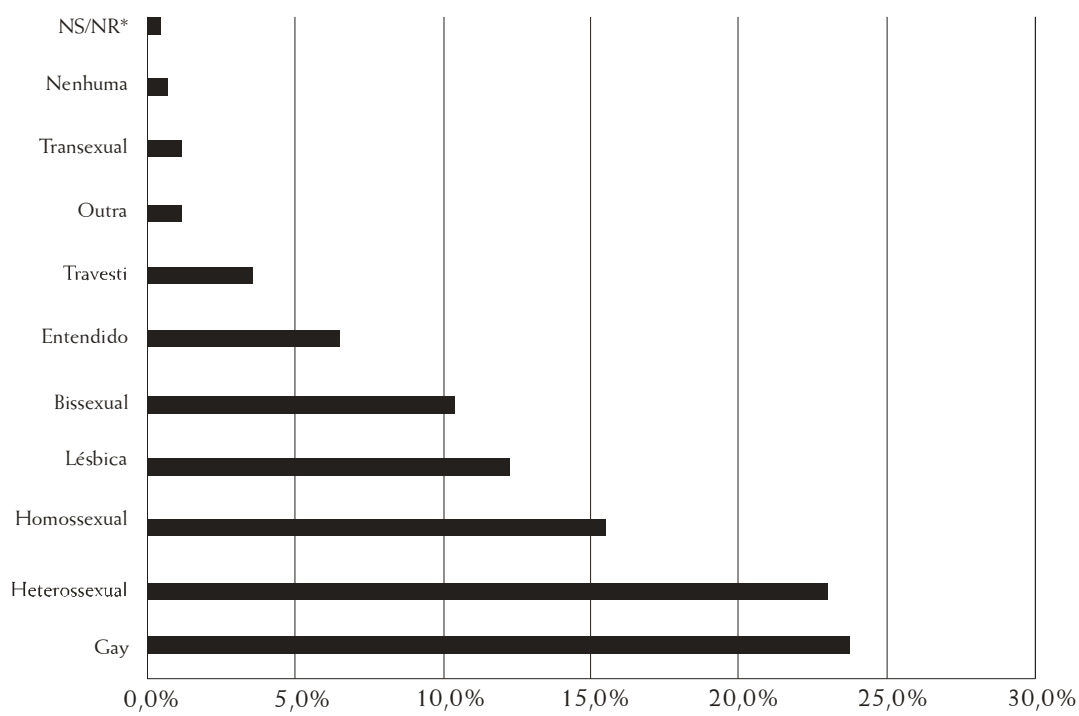

*NS/NR - Não sabe/Não respondeu.

Fonte: Elaborado pelos autores com base em dados do Clam/IMS/Uerj e do CESeC/Ucam.

Quando se trata de discriminação por amigos e vizinhos, 38,8\% das 'mulheres trans' relataram esse tipo de experiência, seguidas de perto por 'homens homossexuais' $(37,2 \%)$ e 'homens bissexuais' (30,3\%). Um padrão semelhante acontece quando se trata do ambiente escolar, em relação a 
colegas e professores. Nele, um número expressivo de 'homens homossexuais' $(37,4 \%)$ e 'mulheres trans' $(34,4 \%)$ sentiu-se discriminado, seguidos pelos 'homens bissexuais' $(27,8 \%)$.

Gráfico 2 - Identidades sexuais agregadas

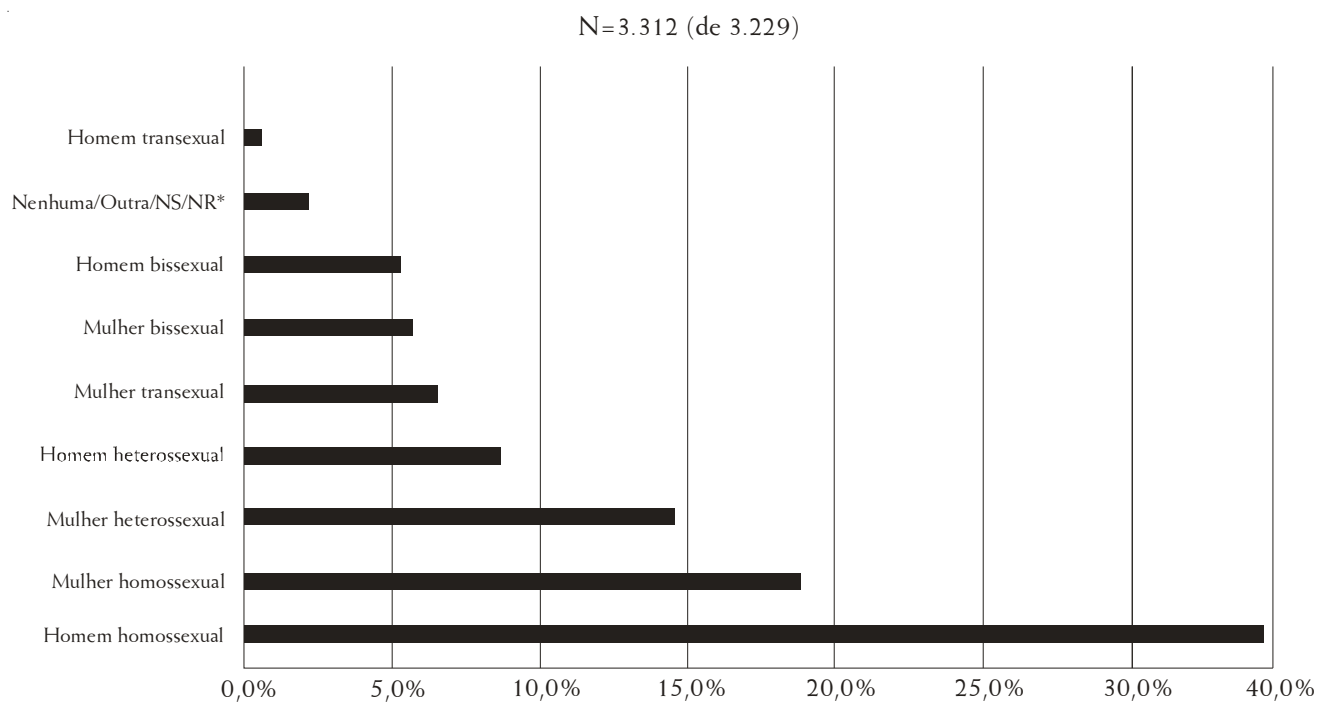

*NS/NR - Não sabe/Não respondeu.

Fonte: Elaborado pelos autores com base em dados do Clam/IMS/Uerj e do CESeC/Ucam.

Como se vê, nesses círculos, a diferença média entre os que se sentiram menos e mais discriminados é de 7 pontos percentuais. Desse modo, as 'mulheres trans' relataram em média o mesmo número de experiências de discriminação que 'homens homossexuais' - ambos com médias ligeiramente superiores às de 'homens bissexuais'. O fato de os três grupos estarem próximos no que diz respeito à discriminação em círculos mais íntimos de sociabilidade deve-se muito provavelmente ao fato de que é nesses círculos que a orientação sexual ou identidade de gênero dos sujeitos acaba sendo conhecida em algum momento de suas trajetórias. ${ }^{19}$

19 Como os surveys também revelaram, é nesses círculos que a maior parte dos entrevistados(as) já teria 'assumido' sua orientação sexual ou identidade de gênero. Assim, no Rio de Janeiro, em 2004, 'assumia-se' mais frequentemente para amigos (89,5\%) e familiares $(68,8 \%)$. O mesmo quadro se repete nas outras capitais pesquisadas. 
A incidência de experiências de discriminação altera-se significativamente quando avançamos para círculos menos privados de sociabilidade e entramos no mundo público. Assim, enquanto $36,7 \%$ das 'mulheres trans' declararam ter sido discriminadas no trabalho ou na admissão para um emprego, apenas 13,9\% dos 'homens homossexuais' e 9,7\% dos 'homens bissexuais' tiveram experiência semelhante.

Se, em locais comerciais e de lazer, $44,2 \%$ das 'mulheres trans' se sentiram discriminadas, somente $17,8 \%$ dos 'homens homossexuais' e 11,9\% dos 'homens bissexuais' relataram o mesmo.

Em ambiente religioso, as taxas variam entre $41,5 \%$ para 'mulheres trans' e $11,8 \%$ para 'homens bissexuais', permanecendo os 'homens homossexuais' em uma posição intermediária, com 23,1\%.

Ter sido mal atendido em delegacias ou por policiais é relatado, sobretudo, por 'mulheres trans' $(44,3 \%)$, seguidas de longe por 'homens homossexuais' e 'bissexuais', com porcentagens quase idênticas: 19,4\% e $18 \%$, respectivamente.

As relações com serviços de saúde também são apontadas como contextos propícios a experiências de discriminação, ainda que, entre as situações selecionadas para compor o que chamamos aqui de mundo público, elas apresentem índices de discriminação sensivelmente mais baixos do que aqueles observados para outras situações.

A proporção de experiências de discriminação relatadas por 'mulheres trans', como usuárias dos serviços de saúde, chega a 25,2\%, sendo que $30,2 \%$ delas foram impedidas de doar sangue. Esse fato também foi vivido como discriminação por muitos 'homens homossexuais' $(17,7 \%)$, embora um número menor $(11,1 \%)$ tenha passado por situações de discriminação em serviços de saúde. 'Homens bissexuais' viveram a experiência de terem sido preteridos em uma tentativa de doação de sangue $(7,9 \%)$, e um número ligeiramente menor relatou experiência de discriminação em serviços de saúde $(6,9 \%)$.

É certo que o atual impedimento de doar sangue que se impõe a partir do tipo de prática sexual (se heterossexual ou homossexual) mantida pelo potencial doador, e não a partir da utilização ou não de preservativos, mereceria uma discussão à parte. Vale notar que o número dos que foram recusados, isto é, dos que tentaram doar sangue e foram impedidos, é considerável para um país em que se incentiva a doação de sangue de modo geral. ${ }^{20}$ 
Nos círculos de sociabilidade mais formais e que compõem o mundo público, aumenta a diferença entre a categoria mais afetada por situações de discriminação - as 'mulheres trans' - e a categoria menos afetada - em geral, 'homens bissexuais', atingindo a média de 36,7 pontos percentuais. Nesses espaços, 'mulheres trans' relatam duas vezes mais experiências de discriminação, quando comparadas a 'homens homossexuais', e três vezes mais do que 'homens bissexuais'.

Assim, seja por manifestarem atributos não legíveis a partir das convenções de gênero vigentes e, por essa razão, vinculados a práticas sexuais condenáveis, seja simplesmente por demonstrarem que os vínculos entre sexo, orientação sexual e gênero são mais instáveis do que se acredita, as 'mulheres trans' são as vítimas preferenciais da homofobia que acontece no espaço público.

Além de situações de discriminação, a pesquisa buscava também informações sobre as experiências de "agressão" vividas pelo(a)s entrevistado(a)s "devido à sua sexualidade". Incluíram-se como "agressões" as seguintes situações: "violência sexual", "boa-noite, cinderela", ${ }^{21}$ "chantagem/extorsão", "agressão física", "ameaça de agressão/agressão verbal".

Nas quatro cidades pesquisadas, um elevado número de entrevistados $(63 \%)$ relatou ter vivido pelo menos uma das modalidades de agressão. Esse tipo de experiência, bastante comum entre todos, sofre, entretanto, variação se considerarmos as diferentes identidades sexuais agregadas. A única exceção diz respeito aos casos de agressão verbal ou ameaça de agressão, em que as experiências dos três grupos tendem a se aproximar.

Assim, o lugar social da homossexualidade no Brasil permanece ainda hoje marcado pela injúria (Eribon, 2008), e ser objeto de agressões verbais parece quase constitutivo da experiência de ser homossexual, bissexual

${ }^{20}$ Para efeito de comparação, o número de mulheres que tiveram sangue recusado é significativamente menor $-4,3 \%$ entre as 'homossexuais' e apenas $1 \%$ entre as 'bissexuais'. No que concerne a esse problema, talvez devêssemos considerar a permanência entre nós da antiga representação que unia simbolicamente os então chamados "desvios sexuais" às doenças do "sangue" (Carrara, 1996), algo ainda mais reforçado com o advento da epidemia de Aids, cujas vítimas iniciais foram homens que mantinham relações sexuais com outros homens. Em meados da década de 1980, Pollak (1990: 11) afirmava que "suas vias de transmissão pelo sangue e pelo esperma são carregadas de ligações com as ideias de pureza, procriação e reprodução social".

21 O crime consiste na sedação da vítima com soníferos e outras substâncias narcóticas com o objetivo de roubar dinheiro e bens. 
ou mulher trans. Dos 'homens homossexuais' entrevistados, 67,6\% declaram ter experimentado esse tipo de agressão - o mesmo acontecendo com $70,8 \%$ das 'mulheres trans' e $52 \%$ dos 'homens bissexuais'.

Já em relação à agressão física, as experiências diferem sensivelmente. Enquanto quase metade $(47 \%)$ das 'mulheres trans' declarou ter sofrido algum tipo de agressão física em virtude de sua sexualidade, apenas $23 \%$ dos 'homens homossexuais' e 14,6\% dos 'homens bissexuais' relataram o mesmo.

Obviamente, a transgressão mais pública das convenções sociais de gênero e as relações violentas que marcam o igualmente estigmatizado universo da prostituição, em que muitas travestis trabalham, podem explicar em parte tais diferenças. Vale destacar também a incidência diferencial da violência sexual que, no caso das 'mulheres trans', foi relatada por 22,4\% das respondentes, contra 7,9\% entre 'homens homossexuais' e apenas 3,5\% para os 'bissexuais'.

É também notável o modo como a experiência de agressão física diminui consistentemente à medida que aumenta a escolaridade dos entrevistados, caindo em mais de $30 \%$, entre os que declararam ter ensino fundamental completo ou incompleto, para menos da metade (pouco mais de $10 \%$ ) para os que declararam ter ensino superior completo ou incompleto.

Para os três grupos aqui considerados, mais da metade das agressões ocorreu em local público e os agressores foram, sobretudo, desconhecidos. A agressão por desconhecidos foi relatada por $47,5 \%$ dos 'homens homossexuais', chegando a 51,6\% entre as 'mulheres trans'. Mesmo assim, um número não desprezível das agressões ocorreu em casa para 'homens homossexuais' $(15,7 \%)$, 'bissexuais' $(10,2 \%)$ e 'mulheres trans' $(8,2 \%)$, sendo os agressores familiares, amigos ou conhecidos, colegas de trabalho ou faculdade e vizinhos.

Isso aponta para o caráter multifacetado da chamada violência homofóbica. Se, em muitos casos, ela se reveste das características mais clássicas dos chamados 'crime de ódio', em que os/as que têm a 'coragem' (ou o 'descuido') de exibir em público sua diferença são agredidos verbal e fisicamente por desconhecidos, em muitos outros, acontece no contexto de relações sociais afetivamente densas, envolvendo parentes ou amigos. Assim, ao menos quando se trata de homofobia, a 'casa' não parece ser uma proteção tão eficaz contra a violência anônima da 'rua'. 


\section{Negociando limites: visibilidade, discriminação e violência}

Ao analisar os dados estatísticos, percebemos que experiências de discriminação e violência fazem parte da trajetória de parte considerável do(a)s entrevistado(a)s. Ainda que, na maior parte dos países ocidentais, o contexto social e político tenha sofrido grandes transformações desde Stonewall, calcular riscos, sofrer rechaços e optar por revelar ou esconder a homossexualidade ou identificações de gênero não convencionais ainda são preocupações muito presentes, condicionando de maneira permanente o trânsito social de muitas pessoas. Conforme aponta Sedgwick (2007: 22), para muitos, manter-se "no armário", ou seja, não revelar publicamente identidades e práticas não heterossexuais, "ainda é a característica fundamental da vida social, e há poucas pessoas gays, por mais corajosas e sinceras que sejam de hábito, por mais afortunadas pelo apoio de suas comunidades imediatas, em cujas vidas o armário não seja ainda uma presença formadora". Contudo, tentar manter-se "no armário" é apenas uma das inúmeras estratégias que pessoas LGBT podem acionar para lidar com a ameaça concreta de violência, rejeição ou discriminação que os números dos surveys revelam.

Em uma pesquisa realizada na Austrália, durante a década de 1990, Mason (2002) explorou, junto a um grupo de mulheres lésbicas, experiências e percepções de hostilidade verbal, violência física e sexual, relacionadas à orientação sexual. ${ }^{22}$ Acreditamos que muitas de suas conclusões aplicam-se igualmente a 'homens homossexuais', 'bissexuais' e 'mulheres trans', sendo pertinentes à análise que empreendemos a partir de pesquisa qualitativa exploratória realizada com 'homens homossexuais' na cidade do Rio de Janeiro.

Mason aponta para a necessidade de compreender a violência relacionada à homofobia dentro de um discurso sobre visibilidade sexual. Sua proposta se baseia em duas questões principais: a percepção subjetiva

22 Apoiando-se na discussão foucaultiana sobre o panoptismo, Mason (2002) destaca a interpretação que vê nele um modelo extremamente interessante para pensar a interação entre corporalidade, visibilidade e regulação, uma vez que a sociedade contemporânea seria uma sociedade de vigilância, onde a internalização dos processos de individualização e normalização levariam o sujeito a forjar sua própria subjetividade e comportamento. $\mathrm{O}$ relato de suas entrevistadas aparece, assim, como uma forma de acesso a uma realidade construída através do discurso, isto é, uma comunicação verbal de determinadas formas de violação, dor, insulto ou injúria. 
do risco e a negociação que daí advém por parte das pessoas que, sob ameaça, elaboram espécies de "mapas de segurança" que permitem seu trânsito por diversos espaços sociais.

Estratégias de negociação são, portanto, fundamentais, já que a homossexualidade permanece estigmatizada e a decisão por "assumir-se" ou "esconder-se" envolve uma cuidadosa avaliação dos riscos e benefícios. Ao construir esses "mapas", o conhecimento acerca de certas variáveis, como hora do dia, tipo de ambiente ou perfil dos interlocutores, é fundamental para tornar alguém mais ou menos vulnerável aos perigos potenciais da violência.

No discurso dos participantes da pesquisa qualitativa, tais "mapas" se fazem presentes de diferentes maneiras. Thiago, por exemplo, revelou evitar alguns lugares por "saber das coisas que acontecem", como os recorrentes ataques de pitboys no bairro carioca de Ipanema (mais especificamente na rua Farme de Amoedo, muito frequentada por gays e lésbicas): "Nunca se sabe o que vai ter na esquina, apesar de eu nunca ter visto absolutamente nada. Mas eu tomo essa precaução por conta de tudo o que gente ouve falar, o que a gente lê..." (Thiago, enfermeiro, 42 anos).

Para Rodrigo, que já teve a cabeça atingida por uma lata de cerveja ao beijar o namorado na saída de um dos blocos de Carnaval mais tradicionais da cidade, temores semelhantes também fazem com que "mapas de segurança" sejam traçados por ele, a fim de evitar agressões:

É aquela coisa, tem ambientes e ambientes. Numa micareta ${ }^{23}$ não vou fazer isso [beijar o namorado]. Porque eu não sou maluco (...). Eu gosto da minha vida, quero ficar vivo, eu não gosto de brigar, não sei brigar, como é que vai ser? (Rodrigo, psicólogo, 27 anos)

Outros entrevistados expressam a ideia de "experimentação gradual" quando explicam como têm conseguido se manter distantes da violência física. Filipe, por exemplo, disse que a melhor maneira de se preservar seria a partir de uma negociação: "Não é chegar no meio de skinheads e beijar seu namorado e dizer: 'Olha, nós somos gays, estamos aqui para conversar com você', sabe? Não é assim também, a gente tem que ter consciência de que (...) ninguém é tão forte (...). Acho que é ir caminhando aos poucos" (Filipe, analista financeiro, 26 anos).

${ }^{23}$ Espécie de carnaval fora de época, a micareta tem se tornado muito popular entre jovens da classe média urbana do Brasil. 
Como é possível perceber, o limiar da tolerância social é levado em conta ao se fazer uso de determinados mecanismos para minimizar o risco de agressões, de maneira que as noções de "constrangimento", "provocação" e "confusão" se destacam em algumas falas:

Tem algumas coisas que eu não faço, até pra não criar constrangimento; por exemplo, dar um beijo na rua, eu não me sinto à vontade. Porque às vezes (...) eu acho que eu já vou começar a provocar, então eu não provoco pra não ter que brigar (...). Porque uma coisa que pra você é natural pode ter um teor de provocação pra outra pessoa, pode atrair violência (...), coisas que até eu acho que não têm nada de mais, mas que eu prefiro tentar não chocar, assim, na rua... (Rafael, papiloscopista, 27 anos)

Eu por exemplo, nunca andei de braços dados com o meu namorado, nunca beijei ele na boca na frente de todo mundo, como qualquer casal heterossexual faz (...). E na verdade não é medo de apanhar, na verdade eu acho que é medo da confusão (...). O gay não pode ter uma vida como a do heterossexual, em todos os sentidos: andar de mão dada, (...) publicizar questões de carinho (...). (João, cientista político, 35 anos)

Vemos, portanto, que os "mapas de segurança" têm por objetivo reduzir ao máximo a possibilidade de violência homofóbica, mas, da mesma forma que a negociação de limites nos espaços mais restritos ao âmbito privado, funcionam também como uma ferramenta de demarcação de fronteiras. No que segue, a questão será trabalhada em uma perspectiva de visibilidade ainda mais patente, em que o risco é calculado por determinada apresentação de si, moldada pela aparência, controle de gestos e um maior ou menor grau de "afetação" ou "masculinidade". Ainda segundo Mason, tal estratégia envolve a elaboração de "mapas corporais". Da mesma forma que os "mapas de segurança", os "mapas corporais" estariam diretamente ligados à percepção subjetiva da violência potencial, fazendo com que os que se acreditam ameaçados por ela se preocupem muito mais com a maneira pela qual sua apresentação corporal pode ser interpretada por aqueles que os rodeiam. Se existe a possibilidade de passar despercebido, não há como saber quando se está sendo observado, tornando o controle em relação à própria imagem uma necessidade constante. Tudo se passa como se os 'homens homossexuais' entrevistados estivessem presos em uma espécie de panóptico imaterial. ${ }^{24}$ 
Dessa forma, desejar uma apresentação de si em conformidade com as convenções de gênero masculinas teria como função resgatar uma "normalidade aparente" previamente transgredida pelo fato de ser homossexual ou manter práticas homossexuais. Conforme observado anteriormente, para alguns dos informantes aqui apresentados, a preocupação com a aparência é evidente - não só pelo temor da violência física que, como vimos no caso das 'mulheres trans', tende a aumentar quando as convenções de gênero são transgredidas, mas também pela preservação de uma imagem social respeitável. Além de ter tirado o brinco, não pintar mais o cabelo e procurar se vestir "o mais social possível", Bruno disse ter "pavor" de ser visto como uma "bichinha qualquer", esforçando-se para parecer "o mais másculo possível":

Se eu sou careta, se eu sou chato, (...) o problema é meu. É a maneira que eu me acho melhor de estar na sociedade (...). Eu faço academia, eu malho, eu faço natação, eu gosto do meu corpo de homem, entendeu? (...) Eu sou um homem que gosta de outro homem (...). Se eu pudesse ser o (...) máximo parecido com homem másculo possível, eu quero ser. (Bruno, veterinário, 32 anos)

Bruno admitiu haver uma dissociação entre seu comportamento "diante da sociedade" e aquele adotado em ambientes mais íntimos ou tolerantes como boates gays, onde é possível "dar pinta, rebolar e dançar", sem que juízos de valor denegridores sejam uma preocupação.

Paulo criticou esse modo de agir, pois para ele, "ser gay é ser livre", e se existe alguma vantagem em gostar de pessoas do mesmo sexo, é justamente o fato de poder desfrutar de determinadas liberdades pouco vivenciadas pelos heterossexuais:

Tem muita barbie ${ }^{25}$ aí que se prende: 'Ah não, você tem que ter um padrão'. Eu falo: 'Porra, você já é gay, bicha!'. Então você pode dar pinta, você pode escutar a música que você quiser. Você já vai ser discriminado mesmo, então foda-se, entendeu? (...) Tem gays que são assim. Que palhaçada,

${ }^{24}$ De acordo com Foucault (2005: 166-167), a principal finalidade do panóptico seria "induzir no detento um estado consciente e permanente de visibilidade que assegura o funcionamento automático do poder (...) Visível: sem cessar o detento terá diante dos olhos a alta silhueta da torre central de onde é espionado. Inverificável: o detento nunca deve saber se está sendo observado ${ }_{i}$ mas deve ter certeza de que sempre pode sê-lo (...). O panóptico é uma máquina de dissociar o par ver-ser visto: no anel periférico, se é totalmente visto, sem nunca ver; na torre central, vê-se tudo, sem nunca ser visto". 
fazendo linha... eu nunca fiz linha, porra nenhuma, esse negócio de caretice: 'Ah não, você tem que ser macho'. Não, eu acho que você tem que ser você. (Paulo, técnico em edificações, 30 anos)

João, por sua vez, também condenou o que considera uma "imposição da sociedade", destacando a maior vulnerabilidade que homossexuais "afeminados" teriam em relação à violência por estarem transgredindo as convenções de gênero masculinas. Não obstante, afirmou não se tratar do seu caso. Como para Bruno, a prática de esportes parece funcionar como um fator atenuante. ${ }^{26}$

Para Gabriel, preservar a masculinidade parece ter sido fundamental em várias esferas de sua vida. Na relação com o pai, por exemplo, provar que não tinha vontade de se vestir de mulher e que continuava a gostar de futebol foi determinante para uma reação menos hostil:

Quando eu falei pra ele que eu era gay, que eu gostava de homem, mas que não tinha a menor vontade de me vestir como mulher, (...) ele questionou: 'Não?' Eu falei: 'Não, eu estou dizendo que eu sinto atração por homens, física e afetiva, eu gosto de homem'. Nunca tive vontade de me vestir de mulher, nem de brincadeira, em festa; não me sinto bem (...). Meu pai achava que por eu ser gay, eu estava perdendo toda a minha condição de masculinidade. E eu falei pra ele que eu continuava gostando de futebol, que eu ia no Maracanã com ele. Foi quando, engraçado, o meu pai começou a (...) realmente lidar melhor comigo, como filho, que ele via que o filho dele continuava sendo homem. Apesar de ser gay, ele era homem. Sempre deixou claro: 'Nunca vou aceitar, mas o fato de você ser homem, você me faz um favor. As pessoas não vão ver muita coisa, não vou ter vergonha'. (Gabriel, psicólogo, 29 anos).

É interessante constatar como público e privado se entrecruzam na fala do pai de Gabriel. Ao perceber que o filho não havia "perdido" a

25 As barbies são homossexuais que despendem muitas horas em academias de ginástica a fim de modelar um corpo de aparência musculosa e viril, em consonância com os ideais de masculinidade vigentes (Nunan, 2003).

${ }^{26}$ Em seu estudo sobre os significados da masculinidade, Oliveira (2004) traça uma conexão entre a prática de esportes com os valores masculinos. Embora a prática esportiva possa ser encarada de uma perspectiva mais ampla, na qual estão em jogo outras metas, como o bemestar e a saúde, não podemos menosprezar que a valorização do esporte contém uma série de atributos simbólicos associados à masculinidade, como força, vigor, disposição e, em última instância, poder. 
masculinidade, parece haver um alívio em relação ao julgamento dos "outros", que não iriam "ver muita coisa" - discurso que se aproxima de outros relatos, como os de Bruno e Filipe, cujos parentes mostraram-se extremamente preocupados com a possibilidade de eles "envergonharem" a família diante da vizinhança. Logo adiante em sua entrevista, Gabriel explorou mais propriamente o problema do gênero, complementando a fala anterior:

Ver que o Gabriel não ia ser uma bicha... eu realmente acho que seria muito complicado, porque (...) a coisa do gênero, se o homossexual de repente pode virar um transgênero, ou um travesti... eu não sei como é que teria sido (...). Então, isso ajuda. Eu acho que se o gênero tivesse entrado muito nisso, (...) meus pais realmente não teriam aceito. A segurança pros meus pais, principalmente pro meu pai, foi ver que o Gabriel continuava sendo homenzinho. (Gabriel, psicólogo, 29 anos)

Quando perguntado se "manter um certo nível de masculinidade" seria vantajoso não só para a construção de uma boa relação com o pai, mas também em outros ambientes, Gabriel disse "que ajuda". Mesmo questionando a necessidade de preservar uma "imagem profissional", como muitos tentam fazer, não deixou de reconhecer a importância que uma aparência masculina exerce no seu trato com o chefe, bem como em outros círculos majoritariamente heterossexuais.

Eu acho que, mesmo se eu fosse um travesti, eu exigiria respeito. Porque, sim, a gente fala, se fala muito de imagem profissional (...). Isso é uma coisa que hoje me irrita muito. Isso é homofóbico, enclausura (...). Mas sim, não tenho como deixar de dizer que não ajuda; acho que o fato de eu preservar a minha masculinidade, eu vejo, principalmente com os homens heterossexuais, eu ganho, eu me relaciono bem com eles, por causa disso (...). [Meu chefe] se sente seguro comigo, não se sente ameaçado. O homem hétero tem essa coisa, de se sentir muito ameaçado, não pode ter um amigo gay que parece que vai virargay ${ }^{27}$ (...). [Mas] eu sempre conversava, engraçado, eu via que essas informações que eu dava modificava a percepção deles, eles se sentiam seguros: 'Gabriel não é uma ameaça'. (Gabriel, psicólogo, 29 anos)

27 O perigo da "contaminação" foi um dos pilares fundantes da construção da ideia de homofobia em seus primórdios (Weinberg apud Herek, 2004) e remete à oposição que Douglas (1976) faz entre "higiene" e "sujeira", apontando a primeira como uma tentativa de reorganização simbólica. 
Outro aspecto referente à "apresentação de si" como forma de controlar a ameaça de discriminação e violência homofóbica diz respeito ao modo como outros marcadores sociais de diferença, como os de classe ou de raça, interagem com os de gênero e sexualidade. Tomemos, por exemplo, a raça ou a cor autoatribuída pelos entrevistados.

Para Carlos (pesquisador, 36 anos), Paulo e João, que se disseram negros, parece existir uma relação mutuamente potencializadora entre raça/cor, homossexualidade e uma maior perpetração de atos discriminatórios e/ou violentos. Além de Rodrigo, somente Carlos e Paulo afirmaram ter sofrido pelo menos um episódio de violência física plenamente consumada, mas tanto estes dois últimos quanto João foram os que mais relataram situações de discriminação fora de casa.

Carlos, por exemplo, disse já ter sido vítima de "milhões de coisas", destacando uma situação em que levou pedradas de desconhecidos na rua. Paulo, por sua vez, contou sobre um episódio em que apanhou de um heterossexual por tê-lo 'paquerado', mas também mencionou duas situações em que só conseguiu escapar por ter corrido. Em ambas, desconhecia os agressores, embora na primeira acredite que talvez os agressores pudessem conhecê-lo:

Uma vez eu estava passando (...) num lugar que é meio ermo. Uma e pouco da manhã, parou um carro assim e passou, daqui a pouco ele vindo de ré: 'Vamos pegar, vamos pegar'. Acho que já me conheciam, porque eu passava sempre sozinho [por ali]. Aí tive que subir o morro, assim, correndo, porque cismaram com a minha cara (...). Graças a Deus, não chegaram a me pegar; nesse negócio de sebo nas canelas, de correr, eu sou bom, podia até ser velocista. E outra vez também, (...) tinha acabado de vir de uma festa de abertura de uma parada gay, foi tipo ano passado (...). Tinham várias pessoas, tinham umas travestis que foram também, (...) aí nisso parou um carro, pegou umas pedras, e eu estava observando... aí viu, achou que todo mundo fosse viado ali, aí começou a correr atrás; a gente teve que correr mesmo, pra não sofrer violência, de sangrar mesmo, entendeu? (...) Porque discriminação você até releva, mas violência você tem que correr ou tentar se defender. (Paulo, técnico em edificações, 30 anos)

Se os que se disseram negros são os que relatam maior número de experiências de violência é porque diferentes marcadores sociais de diferença interagem na exteriorização e experiência dessa mesma violência. 
Em relação a esse ponto, mais uma vez o trabalho de Mason é inspirador. A autora vai além da ideia de interseccionalidade para explicar a maneira pela qual as identidades funcionam em conjunto. Em vez de pensar em uma interseção entre diferentes marcadores, Mason os vê como constituindo-se mutuamente. Para ela, gênero, classe, raça e/ou sexualidade não estariam apenas em interseção uns com os outros, mas funcionariam como "veículos de articulação" entre si. Desse modo, poderíamos supor que a homossexualidade de homens negros, quando comparada a de homens brancos, adquire valor específico, sendo alvo de reações homofóbicas ainda mais violentas. No entanto, como a própria autora ressalta, o processo de constituição mútua das diferenças sociais não é de todo desprovido de problemas, pois raça, sexualidade, gênero e outras variáveis não só se articulam em uma soma de opressões, mas também "colidem", em uma série de contradições e incomensurabilidades próprias a cada contexto.

\section{Masculinidade e homofobia}

Para autores como Kimmel (2001) e Welzer-Lang (2001), uma maior incidência de intolerância homofóbica em relação aos homens que não se adéquam às convenções de gênero (como explorado anteriormente nos dados dos surveys) poderia ser explicada pela necessidade de desvalorização do feminino, característica marcante das sociedades ocidentais. Se ser "homem" é historicamente sinônimo de dominação, tal poder não é simplesmente "dado" e, muitas vezes, o preço pago por querer corresponder às expectativas associadas à construção de uma identidade masculina positiva é alto. Além de ser objeto de cobranças sociais significativas (muitas vezes acompanhadas de pressões familiares), ao homem cabe reafirmar constantemente sua masculinidade através de um árduo e longo trabalho de construção identitária, permeado principalmente pela demonstração de superioridade física e psicológica.

De acordo com Kimmel, o esforço para manter uma aparência masculina se faz presente em todas as atividades de um homem, como a maneira de falar, comer e andar, de modo que uma linguagem codificada de gênero estaria subscrita em todo maneirismo ou movimento. A possibilidade de ser "desmascarado", portanto, estaria em todos os lugares. Ao tratar da juventude, período em que os homens estariam mais preocupados em exercer mecanismos de autocontrole a fim de se assegurarem de sua própria masculinidade, o autor propõe: 
Como homens jovens, estamos constantemente passeando por essas fronteiras de gênero, verificando as cercas que construímos no perímetro, certificando-nos de que nada remotamente feminino possa aparecer. (...) Até mesmo a coisa mais aparentemente insignificante pode ameaçar ou ativar esse terror assombroso. (Kimmel, 2001: 105)

Apresentando uma perspectiva semelhante, Welzer-Lang acredita que as relações entre homens seriam estruturadas a partir de uma imagem hierarquizada das relações entre homens e mulheres. Qualquer demonstração de fraqueza ou impotência por parte dos primeiros implicaria a ameaça de serem subjugados, visto que as relações sociais de sexo ocorrem de modo transversal ao conjunto da sociedade. Para o autor, é nessa transversalidade que estaria a principal raiz da homofobia, encarada por ele como "a discriminação contra pessoas que mostram, ou a quem se atribui, algumas qualidades (ou defeitos) atribuídos ao do outro gênero", pois "para ser homem, é necessário não ser associado a uma mulher. O feminino se torna até o polo de rejeição central, o inimigo interior que deve ser combatido sob pena de ser também assimilado a uma mulher e ser (mal)tratado como tal" (Kimmel, 2001: 465).

Outros autores irão explorar a valorização de uma estética ou performance masculina do ponto de vista não mais das estratégias individuais, mas do modo pelo qual o movimento gay busca afirmar-se no cenário político mais geral. Pollak (1987: 68), por exemplo, apresenta uma hipótese aplicável especificamente ao meio homossexual, ao menos àquele dos anos 80. Para este autor, uma representação que estivesse o mais distante possível do feminino teria tido sua origem dentro da própria militância. Ao tentar redefinir a identidade homossexual, seus membros teriam se esforçado no sentido de descolá-la "da imagem que faz do homossexual, na melhor das hipóteses, um homem efeminado, e, na pior, uma mulher que não deu certo". Ainda de acordo com ele,

Enquanto o tema da emancipação dos heterossexuais está quase sempre ligado à indiferenciação dos papéis masculinos e femininos, a emancipação homossexual atravessa atualmente uma fase de definição muito estrita de identidade sexual (...). Esta evolução do meio homossexual na direção de um estilo que acentua a virilidade é muitas vezes acusada de ser sexista e leva a marginalizar aqueles homossexuais que não se submetem a essa definição da identidade homossexual. Mesmo reconhecendo esses fenômenos de exclusão, é preciso ressaltar que a busca de uma tal 
identidade muito rígida surge num momento em que, pela primeira vez, se oferece a oportunidade aos homossexuais de construírem sua própria imagem social, e de ressaltarem sua masculinidade, mais do que suas características femininas. Caso em um futuro próximo a sociedade se tornasse mais tolerante para com a homossexualidade, poderíamos esperar um abrandamento dessa necessidade de construir uma imagem "machista". (Pollak, 1987: 68-69)

É importante ressaltar, entretanto, que muitas vezes a preferência por adotar um comportamento mais "conformado" não ocorre de maneira consciente, ou pelo menos, não completamente. Assim como incorporamos em nossas vidas diversas convenções sociais que permitem uma melhor interação com o mundo, por que não incluir a "assimilação da masculinidade" em seu rol?

Acrescido a isso - e talvez um aspecto ainda mais importante no que concerne à discussão empreendida aqui - o controle sobre o próprio corpo poderia funcionar como uma estratégia de recusa à vulnerabilidade, o que nos permite questionar a lógica de que adotar uma aparência mais "masculinizada", ou, no caso das 'mulheres trans', tornar-se indistinguível das mulheres heterossexuais, seja simplesmente uma forma de "assimilação". Como Mason aponta, ao mapear constantemente seus corpos, gays e lésbicas também estariam exercendo uma forma de controle, administrando sua própria visibilidade de modo a assumir as rédeas de situações em que sentimentos hostis podem aparecer.

\section{Conclusão}

Em fevereiro de 2000, o assassinato de Edson Néris, linchado por um grupo de skinheads em uma praça de São Paulo enquanto andava de mãos dadas com outro homem, causou comoção pela brutalidade e ganhou grande repercussão midiática por sua caracterização pela justiça paulista como "crime de ódio" (algo inédito no Judiciário brasileiro) e pela pena relativamente severa aplicada aos réus (Vianna, Lacerda \& Carrara, 2008). Ainda que casos como esse não sejam rotina nas grandes cidades brasileiras, pouco se sabe sobre o que ocorre em cidades menores ou mesmo em contextos sociais mais pobres, onde a denúncia formalizada de atos violentos geralmente é menor. 
Mesmo considerando os já citados levantamentos do Grupo Gay da Bahia e as pesquisas nas Paradas do Orgulho LGBT, os verdadeiros números podem estar subestimados. Soma-se a isso o fato de que, conforme revelam os dados qualitativos apresentados, o que é percebido como discriminação ou violência assume muitas vezes um caráter subjetivo, tornando difícil a caracterização de uma "verdadeira face" da homofobia.

É certo que muito vem mudando no panorama da visibilidade LGBT. Além de conquistas em termos de leis, projetos de lei e decisões judiciais, vivemos atualmente um período em que a exposição da sexualidade como um todo é muito maior. Embora ainda existam divergências, grupos de defesa dos direitos LGBT se organizaram por todo o país, e a articulação entre a esfera municipal, estadual, federal e internacional é uma realidade cada vez mais nítida (Vianna \& Lacerda, 2004).

Todavia, é indispensável que estejamos atentos para não adotar uma postura demasiadamente otimista em relação a esses avanços, pois correríamos o risco de deixar de lado o viés estruturante que certa orientação sexual e/ou identidade de gênero ainda podem conferir ao trânsito social do sujeito, tornando-o mais propenso a sofrer agressões físicas ou verbais, entre outras perdas significativas. Conforme discutido aqui, no que concerne de maneira mais específica à homossexualidade e bissexualidade masculina, bem como à travestilidade e à transexualidade, é possível que esse viés seja ainda mais perceptível, tornando necessário um aprofundamento de determinados componentes que trazem a esse grupo uma maior vulnerabilidade.

\section{Referências}

BRANDÃO, E. R. Renunciantes de direitos? A problemática do enfrentamento público da violência contra a mulher: o caso da Delegacia da Mulher. Physis: Revista de Saúde Coletiva, 16(2): 207-231, 2006.

CARRARA, S. Tributo a Vênus: a luta contra a sífilis no Brasil, da passagem do século aos anos 40. Rio de Janeiro: Editora Fiocruz, 1996.

CARrARA, S. \& RAMOS, S. Política, Direitos, Violência e Homossexualidade: pesquisa $9^{a}$ Parada do Orgulho GLBT - Rio 2004. Rio de Janeiro: Cepesc, 2005.

CARRARA, S. et al. Política, Direitos, Violência e Homossexualidade: pesquisa $9^{a}$ Parada do Orgulho GLBT - São Paulo 2005. Rio de Janeiro: Cepesc, 2006. 
CARRARA, S. et al. Política, Direitos, Violência e Homossexualidade: pesquisa $5^{a}$ Parada da Diversidade - Pernambuco 2006. Rio de Janeiro: Cepesc, 2007.

CORREA, M. Gênero e Cidadania. Campinas: Unicamp, Pagu, 2002.

DOUGlaS, M. Pureza e Perigo. São Paulo: Perspectiva, 1976.

ERIBON, D. Reflexões sobre a Questão Gay. Rio de Janeiro: Companhia de Freud, 2008.

FOUCAULT, M. Vigiar e Punir. Petrópolis: Vozes, 2005.

GREGORI, M. F. Cenas e Queixas: um estudo sobre relações violentas, gênero e feminismo. São Paulo: Paz e Terra, Anpocs, 1993.

HEREK, G. M. Beyond 'homophobia': thinking about sexual prejudice and stigma in the twenty-first century. Sexuality Research \& Social Policy, 1(2): 6-24, 2004.

KIMMEL, M. S. Masculinity as homophobia: fear, shame and silence in the construction of gender identity. In: WHITEHEAD, S. \& BARRETT, F. (Eds.). The Masculinities Reader. Cambridge: Polity Press, 2001.

LOPES, S. da S. Masculinidades Encarceradas: representações sobre o estupro e o estuprador na prisão, 2005. Dissertação de Mestrado, Rio de Janeiro: Instituto de Medicina Social, Universidade do Estado do Rio de Janeiro.

MASON, G. The Spectacle of Violence: homophobia, gender and knowledge. London: Routledge, 2002.

MINAYO, M. C. de S. A violência social sob a perspectiva da saúde pública. Cadernos de Saúde Pública, 10, supl. 1: 7-18, 1994.

MINAYO, M. C. de S. A inclusão da violência na agenda da saúde: trajetória histórica. Ciência \& Saúde Coletiva, 1: 1.259-1.276, 2006.

MOTT, L. Violação dos Direitos Humanos e Assassinato de Homossexuais no Brasil. Salvador: Grupo Gay da Bahia, 2000.

MOTT, L. \& CERQUEIRA, M. Causa Mortis: homofobia. Salvador: Grupo Gay da Bahia, 2001.

NUNAN, A. Homossexualidade: do preconceito aos padrões de consumo. Rio de Janeiro: Caravansarai, 2003.

OLIVEIRA, P. P. de. A Construção Social da Masculinidade. Belo Horizonte: Editora UFMG, 2004.

POLLAK, M. A homossexualidade masculina, ou: a felicidade do gueto? In: ARIÉS, P. \& BÉJIN, A. (Orgs.). Sexualidades Ocidentais: contribuiçôes para a história e para a sociologia da sexualidade. São Paulo: Brasiliense, 1987.

POLlAK, M. Os Homossexuais e a Aids: sociologia de uma epidemia. São Paulo: Estação Liberdade, 1990. 
RAMOS, S. \& CARRARA, S. A constituição da problemática da violência contra homossexuais: a articulação entre ativismo e academia na elaboração de políticas públicas. Physis: Revista de Saúde Coletiva, 16(2): 185-205, 2006.

SARTI, C. A.; BARBOSA, R. M. \& SUAREZ, M. M. Violência e gênero: vítimas demarcadas. Physis: Revista de Saúde Coletiva, 16(2): 167-183, 2006.

SAGGESE, G. Quando o Armário é Aberto: visibilidade e estratégias de manipulação no coming out de homens homossexuais, 2009. Dissertação de Mestrado, Rio de Janeiro. Instituto de Medicina Social, Universidade do Estado do Rio de Janeiro.

SEDGWICK, E. K. A epistemologia do armário. Cadernos Pagu, 28: 19-54, 2007.

SOUZA, E. R. de. Masculinidade e violência no Brasil: contribuições para a reflexão no campo da saúde. Ciência \& Saúde Coletiva, 10(1): 59-70, 2005.

VIANNA, A. \& LACERDA, P. Direitos e Políticas Sexuais no Brasil: o panorama atual. Rio de Janeiro: Cepesc, 2004.

VIANNA, A.; CARRARA, S. \& LACERDA, P. Sexual politics and sexual rights in Brazil: an overview. Global Public Health, 3: 5-21, 2008.

WELZER-LANG, D. A construção do masculino: dominação das mulheres e homofobia. Revista de Estudos Feministas, 9(2): 460-482, 2001.

ZALUAR, A. Um debate disperso: violência e crime no Brasil da redemocratização. São Paulo em Perspectiva, 13(3): 3-17, 1999. 

Formato: $16 \times 23 \mathrm{~cm}$

Tipologia: Goudy e Weiss

Papel: Pólen Bold $70 \mathrm{~g} / \mathrm{m}^{2}$ (miolo)

Cartão Supremo $250 \mathrm{~g} / \mathrm{m}^{2}$ (capa)

CTP, impressão e acabamento: Imos Gráfica e Editora Ltda.

Rio de Janeiro, outubro de 2011

Não encontrando nossos títulos em livrarias, contactar a EDITORA FIOCRUZ:

Av. Brasil, 4036 - 1ํ andar - sala 112 - Manguinhos

21040-361 - Rio de Janeiro - RJ

Tel.: (21) 3882-9007 / Telefax: (21) 3882-9006

www.fiocruz.br/editora

editora@fiocruz.br 
